\title{
RELATION OF PRECIPITATION QUALITY TO STORM TYPE, AND DEPOSITION OF DISSOLVED CHEMICAL CONSTITUENTS FROM PRECIPITATION IN MASSACHUSETTS, 1983-85
}

U.S. GEOLOGICAL SURVEY

Water-Resources Investigations Report 94-4224

Prepared in cooperation with the MASSACHUSETTS DEPARTMENT OF ENVIRONMENTAL PROTECTION, DIVISION OF WATER POLLUTION CONTROL

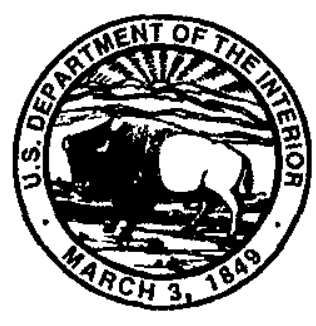




\section{RELATION OF PRECIPITATION QUALITY TO STORM TYPE, AND DEPOSITION OF DISSOLVED CHEMICAL CONSTITUENTS FROM PRECIPITATION IN MASSACHUSETTS, 1983-85}

\section{By Frederick B. Gay and Charles S. Melching}

U.S. GEOLOGICAL SURVEY

Water-Resources Investigations Report 94-4224

Prepared in cooperation with the

MASSACHUSETTS DEPARTMENT OF ENVIRONMENTAL PROTECTION, DIVISION OF WATER POLLUTION CONTROL

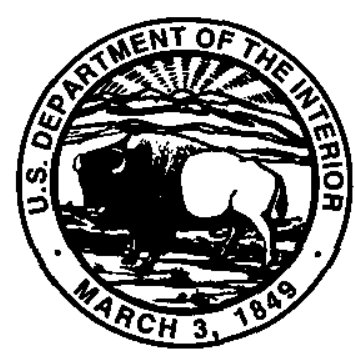

Marlborough, Massachusetts 1995 


\title{
U.S. DEPARTMENT OF THE INTERIOR BRUCE BABBIT, Secretary
}

\author{
U.S. GEOLOGICAL SURVEY \\ Gordon P. Eaton, Director
}

For additional information write to:

Chief, Massachusetts-Rhode Island District

U.S. Geological Survey

Water Resources Division

28 Lord Road, Suite 280

Marlborough, MA 01752
Copies of this report can be purchased from:

U.S. Geological Survey Earth Science Information Center Open-File Reports Section

Box 25286, MS 517

Denver Federal Center

Denver, CO 80225 


\section{CONTENTS}

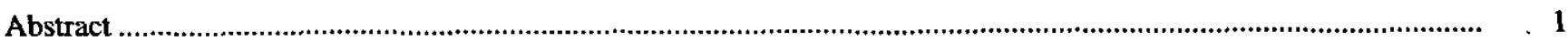

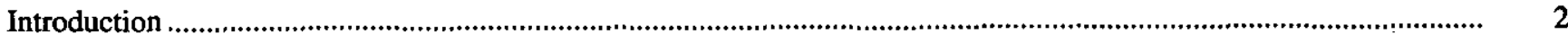

Purpose and Scope .................................................................................................................................

History and Causes of Acidified Precipitation in the Northeastern United States ................................................. 3

Climatic Conditions During the Study Period ..........................................................................................................

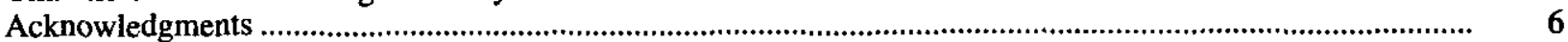

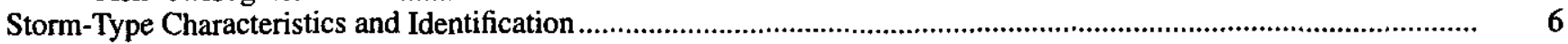

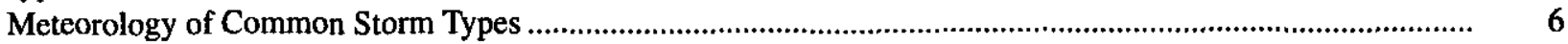

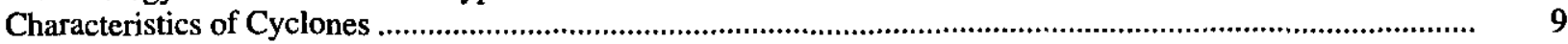

Definition and Description of Common Storm Types ....................................................................................

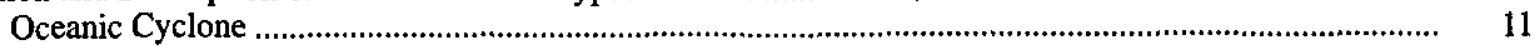

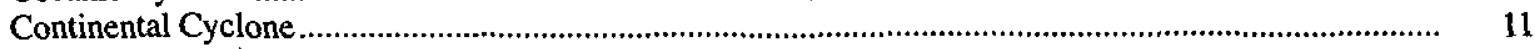

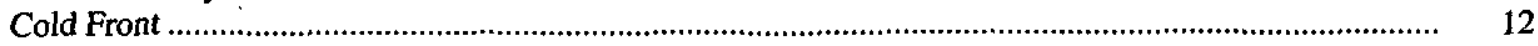

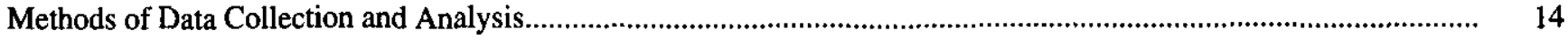

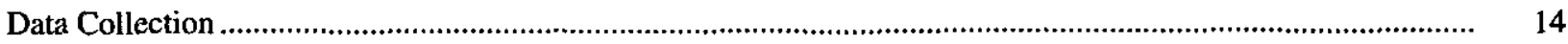

Site-Selection Criteria and Sampling Sites ............................................................................................

Princeton Sampling Site ............................................................................................................. 14

Truro Sampling Site ..................................................................................................................... 15

Equipment Description...................................................................................................................

Sample-Collection and Chemical-Analysis Procedures.............................................................................. 16

Precipitation-Quality Data Analysis ...............................................................................................................

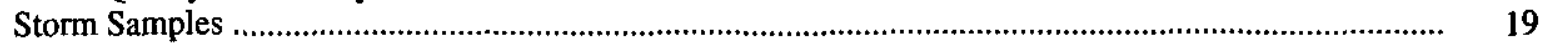

Statistical Analysis for Storm-Type Evaluation .......................................................................... $\quad 20$

Statistical Analysis of Concentration Data .................................................................................... $\quad 20$

Weekly Composite Samples for Calculation of Annual and Seasonal Concentrations and Loads............. 21

. Relation of Precipitation Quality to Storm Type ......................................................................................................... 22

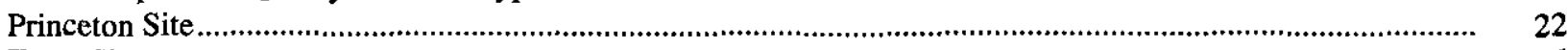

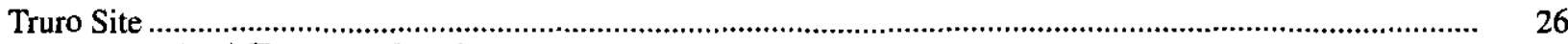

Deposition of Dissolved Chemical Constituents.................................................................................................. 28

Statistical Distributions of Storm and Precipitation-Quality Characteristics ...................................................... 28

Comparison of Constituent Concentrations at Princeton and Truro .....................................................................

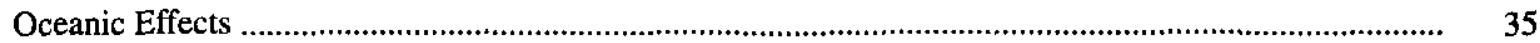

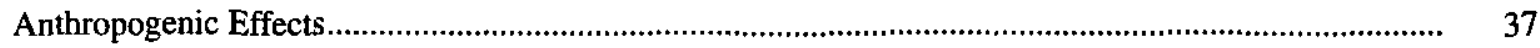

Relation of Constituent Concentrations to Precipitation Depth .............................................................................

Annual and Seasonal Constituent Concentrations and Loads ....................................................................... 41

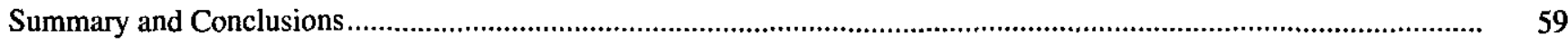

References Cited

\section{FIGURES}

1. Map showing locations of precipitation-sampling sites and selected National

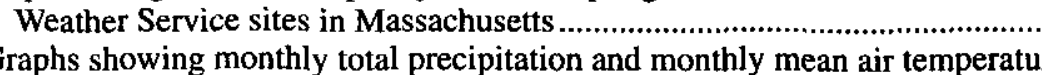

2. Graphs showing monthly total precipitation and monthly mean air temperature

at National Weather Service station in Worcester, Mass., for September 1983

through April 1985 and the departures from the mean monthly precipitation

and air temperature for base period 1951-80

3. Map showing typical configuration of a cyclone affecting the northeastern United States

4. Generalized vertical sections through advancing warm and cold fronts

5. Typical sections through rapidly advancing cold fronts colliding with warm, moist air. 


\section{CONTENTS--Continued}

6-10. Graphs showing

6. Concentrations of major dissolved constituents in storm-precipitation samples, Princeton and Truro, Massachusetts, 1983-85.

7. Relations between hydrogen ion concentration and nitrate concentration and (or) concentrations of several forms of sulfate in precipitation at Princeton, Massachusetts, 1983-85 …................ 38

8. Relations between hydrogen ion concentration and nitrate concentration and (or) concentrations of several forms of sulfate in precipitation at Truro, Massachusetts, 1983-85........................ 40

9. Relations between concentrations of various constituents in precipitation and depth of storm precipitation at Princeton, Massachusetts, 1983-85.

10. Relations between concentrations of various constituents in precipitation and depth of storm precipitation at Truro, Massachusetts, 1983-85.

\section{TABLES}

1. Common chemical constituents applied in the evaluation of precipitation in Massachusetts, 1983-85, and analytical detection limits

2. Common and scarce trace elements applied in the evaluation of precipitation in Massachusetts, 1983-85, and analytical detection limits

3. Ranked-mean precipitation characteristics and constituent concentrations by storm type for Princeton, Massachusetts, 1983-85, and results from the Kruskal-Wallis test of differences among the ranked means.

4. Ranked-mean constituent loads by storm type for Princeton, Massachusetts, 1983-85, and results from the Kruskal-Wallis test of differences among the ranked means.

5. Ranked-mean precipitation characteristics and constituent concentrations by storm type for Truro, Massachusetts, 1983-85, and results from the Kruskal-Wallis test of differences among the ranked means

6. Ranked-mean constituent loads by storm type for Truro, Massachusetts, 1983-85, and results from the Kruskal-Wallis test of differences among the ranked means

7. Statistics of precipitation characteristics and chemical constituents for storm data at Princeton, Massachusetts, 1983-85

8. Statistics of precipitation characteristics and chemical constituents for storm data at Truro, Massachusetts, 1983-85

9. Total number of samples, concentration range, and number of samples less than the detection limit for scarce trace elements in precipitation at Princeton, Massachusetts, 1983-85

10. Total number of samples, concentration range, and number of samples less than the detection limit for scarce trace elements in precipitation at Truro, Massachusetts, 1983-85.

i1. Volume-weighted mean seawater concentrations in precipitation at Princeton and Truro, Massachusetts, 1983-85

asonal precipitation characteristics and constituent concentrations at the National Atmospheric Deposition Program site at Quabbin Reservoir, Massachusetts, spring 1983 through winter 1985.

13. Seasonal constituent loads in precipitation at the National Atmospheric Deposition

Program site at Quabbin Reservoir, Massachusetts, spring 1983 through winter 1985

14. Seasonal precipitation characteristics and constituent concentrations at the National Atmospheric Deposition Program site at Waltham, Massachusetts, spring 1983 through winter 1985 .

15. Seasonal constituent loads in precipitation at the National Atmospheric Deposition Program site at Waltham, Massachusetts, spring 1983 through winter 1985 


\section{CONTENTS--Continued}

16. Seasonal precipitation characteristics and constituent concentrations at the National Atmospheric Deposition Program site at Truro, Massachusetts, spring 1983

through winter 1985

17. Seasonal constituent loads in precipitation at the National Atmospheric Deposition

Program site at Truro, Massachusetts, spring 1983 through winter 1985.

18. Annual precipitation characteristics and constituent concentrations at three National Atmospheric Deposition Program sites in Massachusetts,

spring 1983 through winter 1985

19. Annual constituent loads in precipitation at three National Atmospheric

Deposition Program sites in Massachusetts, spring 1983 through winter 1985

20. Mean annual constituent loads based on the volume of precipitation measured by the rain gage at the three National Atmospheric Deposition Program sites in

Massachusetts, spring 1983 through winter 1985

21. Physical data and chemical-constituent concentrations for storm-precipitation samples

collected at Princeton, Massachusetts, September 1983 through April 1985

22. Physical data and chemical-constituent concentrations for storm-precipitation samples

collected at Truro, Massachusetts, September 1983 through April 1985 


\section{CONVERSION FACTORS, VERTICAL DATUM, WATER-QUALITY INFORMATION, AND ABBREVIATIONS}

\begin{tabular}{rll} 
Multiply & By & To Obtain \\
\hline kilometer $(\mathrm{km})$ & 0.6214 & mile \\
kilopascal $(\mathrm{kPa})$ & 0.1450 & pound-force per square inch \\
$\operatorname{liter}(\mathrm{L})$ & 1.507 & quart \\
$\operatorname{meter}(\mathrm{m})$ & 3.281 & foot \\
micrometer $(\mu \mathrm{m})$ & 0.00003937 & inch \\
millimeter $(\mathrm{mm})$ & 0.03937 & inch \\
milliliter $(\mathrm{mL})$ & 0.0338 & ounce, fluid \\
Temperature in degrees Celsius $\left({ }^{\circ} \mathrm{C}\right)$ can be converted to degrees Fahrenheit $\left({ }^{\circ} \mathrm{F}\right)$
\end{tabular}

\section{VERTICAL DATUM}

Sea Level: In this report "sea level" refers to the National Geodetic Vertical Datum of 1929 (NGVD of 1929)--a geodetic datum derived from a general adjustment of the first-order level nets of both the United States and Canada, formerly called Sea Level Datum of 1929.

\section{WATER-QUALITY UNITS}

Chemical concentrations are given in milligrams per liter $(\mathrm{mg} / \mathrm{L})$ or micrograms per liter $(\mu \mathrm{g} / \mathrm{L})$. Milligrams and micrograms per liter are units expressing the weight of the solute per unit volume (liter) of water. One thousand micrograms per liter is equivalent to 1 milligram per liter. Micrograms per liter is equivalent to "parts per billion."

\section{ABBREVIATIONS}

$\mu \mathrm{S} / \mathrm{cm}$ microsiemen per centimeter at 25 degrees Celsius

$\mathrm{mg} / \mathrm{m}^{2}$ milligram per square meter

$\mu \mathrm{g} / \mathrm{m}^{2} \quad$ microgram per square meter

$\mu \mathrm{eq} / \mathrm{L}$ microequivalent per liter 


\title{
RELATION OF PRECIPITATION QUALITY TO STORM TYPE, AND DEPOSITION OF DISSOLVED CHEMICAL CONSTITUENTS FROM PRECIPITATION IN MASSACHUSETTS, 1983-85
}

\author{
By Frederick B. Gay and Charles S. Melching
}

\section{Abstract}

Precipitation samples were collected for 83 storms at a rural inland site in Princeton, Mass., and 73 storms at a rural coastal site in Truro, Mass. to measure the quality of precipitation from storms and to relate precipitation quality to three storm types (oceanic cyclone, continental cyclone, and cold front). A statistical analysis, the nonparametric Kruskal-Wallis test, was used to test whether any of the 3 storm characteristics (depth, duration, and intensity) and 23 chemical constituents measured, including major cations and anions and selected trace elements, were significantly affected by storm type at the 5 -percent significance level. At the inland site, ranked means (approximately equal to the median) of precipitation depth; storm duration; specific conductance; and concentrations and loads of hydrogen, sulfate, aluminum, bromide, and copper ions were affected by storm type. At the coastal site, ranked means of precipitation depth; storm duration; and concentrations and loads of calcium, chloride, magnesium, potassium, and sodium ions were affected by storm type. Oceanic and continental cyclones at both sites generally produced equal ranked-mean concentrations for those constituent concentrations that were related to storm type. At the inland site, cold-front storms produced higher ranked-mean specific conductances and concentrations of hydrogen, sulfate, aluminum, bromide, and copper ions than did cyclones, reflecting the higher amounts of continental air in cold fronts than in cyclones. At the coastal site, cyclones produced higher ranked-mean concentrations of calcium, chloride, magnesium, potassium, and sodium ions than did cold fronts, reflecting the higher amounts of oceanic air in cyclones than in cold fronts.

Oceanic effects on precipitation quality are indicated by comparing microequivalents computed from volume-weighted mean concentrations of the common chemical constituents at the two sites. The sum of the microequivalents for the major cations and anions equals 446 microequivalents per liter at the coastal site, 1.5 kilometers from the Atlantic Ocean, and 106 microequivalents per liter at the inland site, 72 kilometers from Boston Harbor and 120 kilometers from the Connecticut coast. The principal ions in precipitation at the coastal site were sodium and chloride ( 70 percent), whereas the principal ions in precipitation at the inland site were hydrogen and sulfate ( 50 percent). Precipitation at the coastal site contains about 14 times more sodium, 9 times more chloride and magnesium, and 2 times more calcium, potassium, and sulfate than measured in precipitation at the inland site. In contrast, precipitation at the coastal site contained only slightly less hydrogen, nitrate, and ammonium ions than precipitation at the inland site. Analyses of sea-salt contributions to precipitation quality indicated that more than 90 percent of the chloride, sodium, and magnesium; 86 percent of the potassium; and 72 percent of the calcium in precipitation at the coastal site came from the ocean; whereas, at the inland site, considerably smaller percentages of these constituents came from the ocean (from 6 to 67 percent, with an 
average of about 31 percent). In addition, the analysis of sea-salt contributions indicated that, at the coastal and inland sites, oceanic sulfate constituted 46 and 6 percent, respectively, of the total sulfate concentrations in precipitation. Subtraction of the oceanic sulfate from the overall sulfate concentrations indicated that precipitation at the coastal and inland sites contained about the same concentration (1.04 and 1.11 milligrams per liter, respectively) of non-oceanic sulfate, derived primarily from the burning of fossil fuels.

Data from the National Atmospheric Deposition Program were used to measure specific conductance and constituent concentrations and calculate loads of hydrogen ion, calcium, magnesium, sodium, potassium, sulfate, chloride, nitrate, and ammonium in precipitation on an annual and seasonal basis from spring 1983 through winter 1985 at three sites (Quabbin, Waltham, and Truro) in Massachusetts.

Analysis of annual loads indicates a definite east-west gradient across the State for some constituents. No trends in orthophosphate phosphorus and calcium were found across the State with respect to concentrations and loads. Magnesium, potassium, sodium, and chloride were highest at the coast and much lower inland with very little difference between Waltham and Quabbin. The dominance of these constituents at the coast (Truro) is a result of the entrainment of sea salt in precipitation. Loads of ammonium, nitrate, sulfate, and hydrogen are highest at Quabbin and are about equal at Waltham and Truro. This is opposite the trends for magnesium, potassium, sodium, and chloride. Higher ammonium load at Quabbin over that for the urban/suburban area of Waltham or the coastal area of Truro probably is the result of fertilizer use and decaying organic matter in the rural areas near Quabbin. Higher nitrate load at Quabbin also is attributed to fertilizer use and to the burning of fossil fuels, which also is a source of sulfate and hydrogen. About twice as much nitrate and hydrogen and about 35 percent more sulfate are deposited at Quabbin than at either Waltham or
Truro; this pattern indicates that the interior of Massachusetts receives more acid precipitation than do eastern or coastal areas of Massachusetts.

Storm data at Princeton and Truro and weekly composite data at Quabbin, Waltham, and Truro indicate that oceanic effects on precipitation quality are substantial at the coast but decrease rapidly inland. Effects of fossil-fuel combustion on precipitation quality are significant for nitrate and hydrogen ions at inland sites (Princeton and Quabbin) and for sulfate ions at all other study sites. The relatively high concentrations and loads of hydrogen ion, nitrate, and non-oceanic (primarily anthropogenic) sulfate measured in this study indicate that much of Massachusetts was receiving acid precipitation during the study (March 1983 through April 1985).

\section{INTRODUCTION}

Water-quality degradation in Massachusetts has been widely publicized, and speculation about the effect of acid rain in the degradation process has been considerable. Because precipitation is the primary source of freshwater, more information about the quality of precipitation is needed so that the chemical characteristics of water supplies can be understood and managed. An understanding of chemical characteristics of precipitation is needed to assess the effects of precipitation on reservoirs, lakes, ponds, rivers, ground water, agricultural areas, forests, wetlands, and structures such as bridges, buildings, and monuments.

In order to better understand the chemical characteristics of precipitation, the U.S. Geological Survey (USGS) in cooperation with the Massachusetts Department of Environmental Protection, Division of Water Pollution Control, studied precipitation quality in Massachusetts during 1983-85. The original goal of this study was to relate precipitation quality to the source of airmasses by examination of tracks (travel paths) taken by airmasses from which precipitation originates and through which it falls. However, storm-track direction was difficult to determine because the movement of the various airmasses that converge to cause precipitation is distinct for each storm and difficult to classify. Therefore, the primary goal of this study was changed to examine the relation between precipitation quality and 
storm type and consider the storm track in a more general way. The effects of four storm types (continental cyclone, oceanic cyclone, cold front, and warm front) on precipitation quality were studied. These four storm types were selected because they yield most of the precipitation in Massachusetts. A secondary goal of the study was to determine the annual and seasonal concentrations and loads of dissolved chemicals deposited onto Massachusetts by all storms. Precipitation-quality data used for storm-type analysis and to compute annual and seasonal concentrations and loads were collected at USGS and National Atmospheric Deposition Program (NADP) gages, respectively, in Massachusetts shown in figure 1 .

\section{Purpose and Scope}

This report presents the results of a study of selected water-quality properties and dissolved chemical constituents in precipitation samples collected at sites in eastern Massachusetts. Presented in the report are (1) the relations of three storm types (continental cyclone, oceanic cyclone, and cold front) to precipitation quality on the basis of data collected for storms at two sites in eastern Massachusetts from September 1983 through April 1985, and (2) the annual and seasonal concentrations and loads of dissolved chemical constituents deposited onto Massachusetts, on the basis of data from all storms at three locations from March 1983 through April 1985. Precipitation from a fourth storm type, warm-front storms, was not analyzed because of insufficient data.

Precipitation-quality data used for storm-type analyses were collected at Princeton and Truro, Mass. by USGS personnel. Precipitation-quality data used to compute annual and seasonal concentrations and loads were collected and analyzed by the NADP at Quabbin Reservoir, Waltham, and Truro, Mass. (fig. 1). The USGS and the NADP used the same site at Truro for the precipitation-quality measurements.

The effects of storm types on precipitation quality were evaluated on the basis of chemical analyses of water samples from 70 and 66 storms collected at Princeton and Truro, respectively, during a 20 -month period from September 1983 through April 1985 and from one unusual storm type for the northeast, Hurricane Gloria, on September 26-27, 1985. These water samples were analyzed for physical properties (specific conductance and $\mathrm{pH}$ ) and the concentrations of dissolved common chemical constituents and trace elements. Precipitation from an additional 13 and 7 storms was sampled at Princeton and Truro, respectively, but identification of storm type was difficult and these storms were omitted from the analysis of the effects of storm type on precipitation chemistry. Annual and seasonal contributions of dissolved chemicals to central and eastern Massachusetts were evaluated on the basis of chemical analyses of weekly samples of precipitation collected by the NADP at three sites from March 1983 through April 1985.

\section{History and Causes of Acidified Precipitation in the Northeastern United States}

Massachusetts and other Northeastern States have received precipitation with a $\mathrm{pH}$ of 4.0 to 4.5 since at least 1955 (Cogbill and Likens, 1974; Likens and others, 1979; Cowling, 1982; Glass and others, 1982). Thus, precipitation in Massachusetts contains 13 to 40 times more hydrogen ion than pure water in equilibrium with atmospheric carbon dioxide at standard temperature $\left(20^{\circ} \mathrm{C}\right)$ and pressure $(101.3 \mathrm{kPa})$ and with normal concentrations and pressures of carbon dioxide in the atmosphere; under such conditions, $\mathrm{pH}=5.6$. This $\mathrm{pH}$ is commonly cited as "natural" or "normal" pH for precipitation unaffected by human activities (Likens and others, 1979). However, a recent evaluation by Turk (1983) indicates that $\mathrm{pH}$ for precipitation "in the absence of significant anthropogenic acidification" can range from 4.5 to 5.6 depending on the quantity of naturally occurring nitrogen and sulfur compounds in the atmosphere. Furthermore, Turk (1983, p. 5) stated,
Although the assumption of a natural precipitation $\mathrm{pH}$ of 5.6 is unsupportable, $\mathrm{pH}$ isopleths less than about 5.0 (Cogbill and Likens, 1974) probably delineate areas of anthropogenically acidified precipitation. In 1955-56, this included the area bounded by Ohio on the west, North Carolina on the south, and Maine on the northeast.

When this area became acidified is unknown; however, after examining precipitation quality from two earlier studies, Cogbill and Likens (1974) concluded that the $\mathrm{pH}$ of precipitation in Tennessee and central New York prior to 1930 was at least 4.6 and probably greater than 5.6. This conclusion implies that 


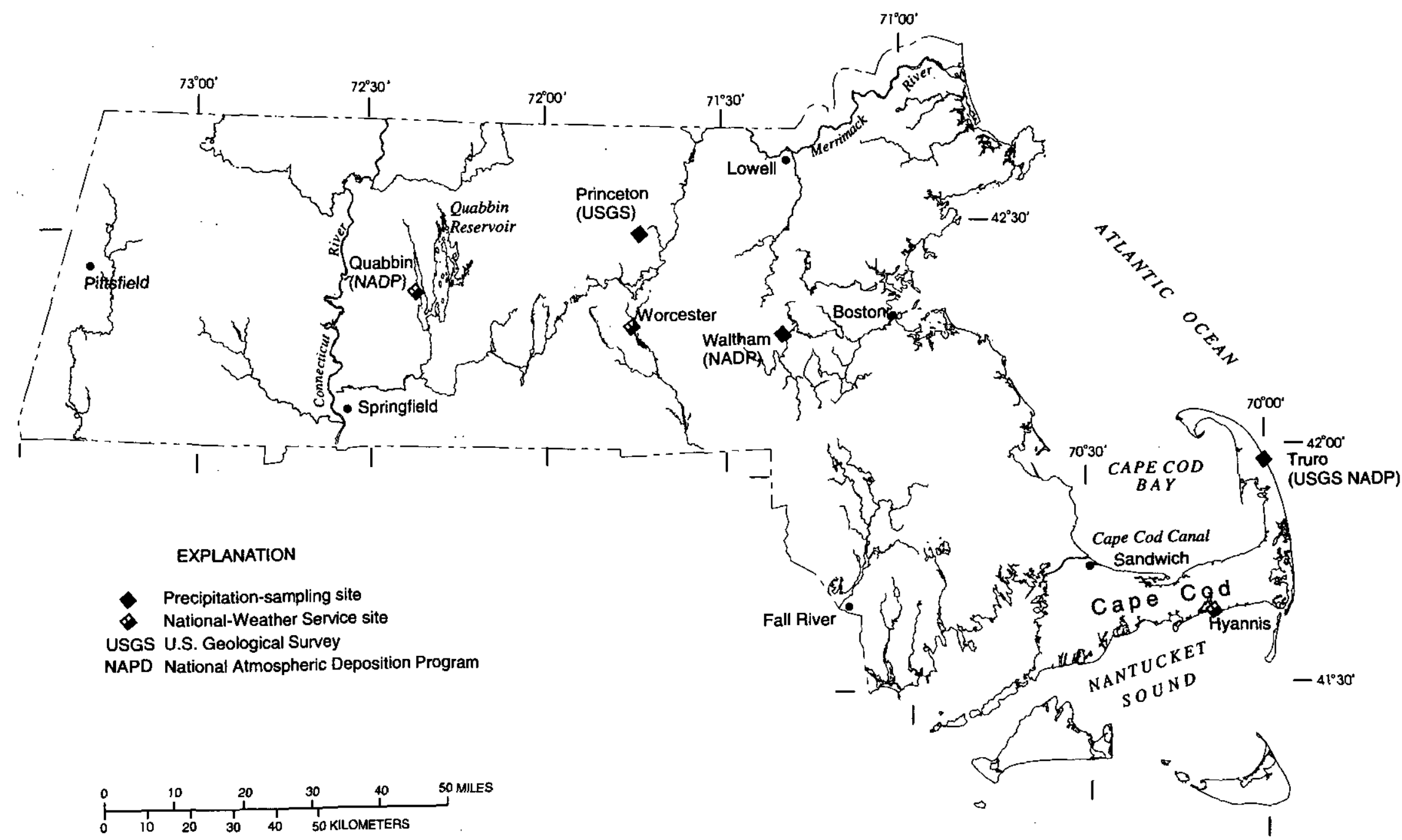

Figure 1. Locations of precipitation-sampling sites and selected National Weather Service sites in Massachusetts. 
the Northeast probably began to receive acidified precipitation after 1930 but before 1955 , which is the earliest year for which acid precipitation has been documented.

The components causing precipitation to become acidic originate as various gases containing oxides of carbon, nitrogen, and sulfur and as particulate matter discharged mainly to the surface layer of the atmosphere (0-600 $\mathrm{m}$ above land surface). Anthropogenic sources of oxides of carbon, nitrogen, and sulfur include power-generation stations, incinerators, smelters, refineries, automobiles, and commercial and home heating systems. Water vapor and trace amounts of heavy metals such as copper, lead, iron, manganese, and zinc also are emitted from anthropogenic sources of the oxides of carbon, nitrogen, and sulfur.

Natural sources of sulfur in the atmosphere include sea spray containing sulfate, organic compounds from bacterial decomposition of organic matter, reduction of sulfate in oxygen-depleted waters and soils, emissions from volcanoes, and forest fires. In eastern North America, biogenic emissions of sulfur can be expected from decaying vegetation, waterlogged soils, freshwater marshes and bogs, marine salt marshes, tidal flats, mangrove swamps, barrier islands, and estuaries (Galloway and Whelpdale, 1980). Despite the many natural sources of sulfur in the atmosphere, anthropogenic emissions of sulfur to the atmosphere were estimated to exceed natural emissions by a factor of 10 (Galloway and Whelpdale, 1980).

Munger and Eisenreich (1983) report that 99 percent of airborne ammonia originates from biological processes, the most important of which is the decomposition of organic waste. A considerable amount of this organic waste may derive from human activity-primarily agricultural activity and sewage disposal. Munger and Eisenreich also noted that emission of nitrate to the atmosphere doubled between 1955 and 1975 and that much of this increase can be attributed to the nearly tripled use of nitrogen fertilizers between 1962 and 1975.

Once in the atmosphere, the gaseous oxides of sulfur and nitrogen are converted to sulfuric and nitric acids by hydrolysis in the presence of sunlight, water vapor, and catalysts. In turn, these acids dissolve chemical constituents from the surfaces of suspended particulates (dust) in the atmosphere. The disassociation of the hydrogen ions contained in nitric and sulfuric acids in the atmosphere is mainly responsible for the reduction of $\mathrm{pH}$ to less than 5 in precipitation.

The mixture of gases, particulate matter, water vapor, acids, and dissolved constituents in the atmosphere moves because of the upward flow of air caused by rising topography and convection currents set in motion by buoyancy (density) differences within the air column. Buoyancy differences cause cold, dry air to sink below warm, moist air, and warm, moist air to rise above cold, dry air. The density of air is affected by a combination of factors, including temperature and water content.

Precipitation is an effective atmospheric scrubber. Minute particles may function as condensation nuclei for water vapor, snowflakes, or hail, or they may be scavenged from the atmosphere by collision with falling precipitation. During the growth process and while falling through the atmosphere, precipitation particles sorb and dissolve atmospheric gases if in liquid phase and sorb and entrap gases if in solid phase (snowflake or ice crystal). These processes are collectively referred to as rainout when occurring within clouds and washout when occurring below clouds. Washout mainly removes particles through collision and gases through sorption. It is through rainout and washout that precipitation becomes a fingerprint of the acids, trace elements, and minute particulate matter present in that part of the atmosphere from which precipitation originates (clouds) and in the atmosphere below the clouds through which it falls.

The northeastern United States lies under the prevailing westerlies, an easterly flow of air that moves across the continent in its circulation of the globe at mid-latitudes. Cold air from Canada and warm air from the Gulf of Mexico and the subtropical water off the eastern United States move into this circulation pattern. Most precipitation is caused by either (1) the interaction of these cold and warm airmasses, each flowing over different parts of the Earth's surface, or (2) the rapid rise of warm, moist air resulting from surface heating or mechanical lifting, such as air rising over a mountain range. Meteorologists have categorized storms by the factors causing the lifting of warm, moist air that results in the cooling needed to produce significant precipitation. For example, cyclonic precipitation is caused by the lifting of air as it converges into a center of low pressure; whereas cold-front precipitation is caused by 
the warm, moist air being forced upward by an advancing cold front. The variation in precipitation quality among storm types may provide insight regarding the cause of the variability in precipitation quality measured for selected storms. Other investigators who have related precipitation quality to meteorological factors, such as storm type, include Kennedy and others (1979), Wolff and others (1979), Raynor and Hayes (1982), Haagenson and others (1985), and Willey and others (1988).

\section{Climatic Conditions During the Study Period}

Monthly precipitation and mean air temperature at the National Weather Service (NWS) station at Worcester Airport in Worcester, Mass., (fig. 1) are shown in figure 2 for September 1983 through April 1985, when most of the precipitation samples were collected for the study. During this period, there were months of aboveand below-average precipitation and (or) air temperature relative to the 1951-80 NW'S base period. Precipitation or air temperature was substantially above average for 4 months in the sampling period. Departure of precipitation from the long-term mean monthly value was greater than 100 percent in November 1983 and May 1984. Departure of air temperature from the longterm mean monthly value was greater than $3^{\circ} \mathrm{C}$ in February and December 1984.

Two distinct periods for precipitation rates were apparent: one of mostly above-average precipitation from September 1983 through July 1984 and one of mostly below-average precipitation from August 1984 through April 1985. Departures from mean monthly precipitation indicate that precipitation during these periods was neither in a phase of prolonged drought nor in a phase of excessive wetness. During this period, however, air temperature for the most part was either average or greater than average and was not similar to the departure curve for precipitation. Nearly all the greater than average monthly temperatures were during cool periods of the year, decreasing the demand for fossil-fuel consumption for heating. Records from the NWS station at Hyannis (fig. 1) on Cape Cod show similar periods when precipitation and temperature were above and below mean monthly values.

\section{Acknowledgments}

The authors acknowledge and thank the persons and organizations who generously gave time and information to this study. Particular thanks are given to $\mathrm{Mr}$. Herbert Olsen, Superintendent of the National Park Service (NPS), Cape Cod National Seashore; Mr. John Portnoy, head of the NPS Atlantic Coast Laboratory in Truro, Mass.; and Dr. John Fitch, Director, and Dr. Betsy Colburn of the Massachusetts Audubon Society Environmental Science Department. Without their permission and help, it would not have been possible to locate the wet/dry automatic precipitation collectors on the respective properties that they managed. In addition, special thanks are in order to Mr. Bud Morrison and Mr. Joseph Choiniere, property managers at the Audubon Wachusett Meadow Wildlife'Sanctuary, for their cooperation during the data-collection phase of the study. Special thanks also are extended to Ms. Jennifer Wood, private citizen and water-quality observer, for her exceptional efforts in collecting storm-precipitation samples and shipping those samples to the Boston office of the USGS for further processing.

\section{STORM-TYPE CHARACTERISTICS AND IDENTIFICATION}

An understanding of the meteorologic and climatic variables and processes that cause and characterize the types of storms examined in this study is necessary in order to comprehend the relations between storm type and precipitation quality determined in this study. Knowledge of the moving airmasses that interact to cause precipitation was particularly important to the goals of this study. With this knowledge, the source areas of particulates that provide condensation nuclei for raindrop formation and strongly affect precipitation quality could be inferred. In addition, the variation in airmass movement for the different storm types may partly explain the differences in precipitation quality among storm types. The meteorology of common storm types and the typical airmass movements and sources of particulates (continental air or oceanic air) for these storm types are described in the following sections.

\section{Meteorology of Common Storm Types}

Weather systems affecting Massachusetts can be classified into three general types: anticyclonic, cyclonic, and advancing frontal boundary. The 

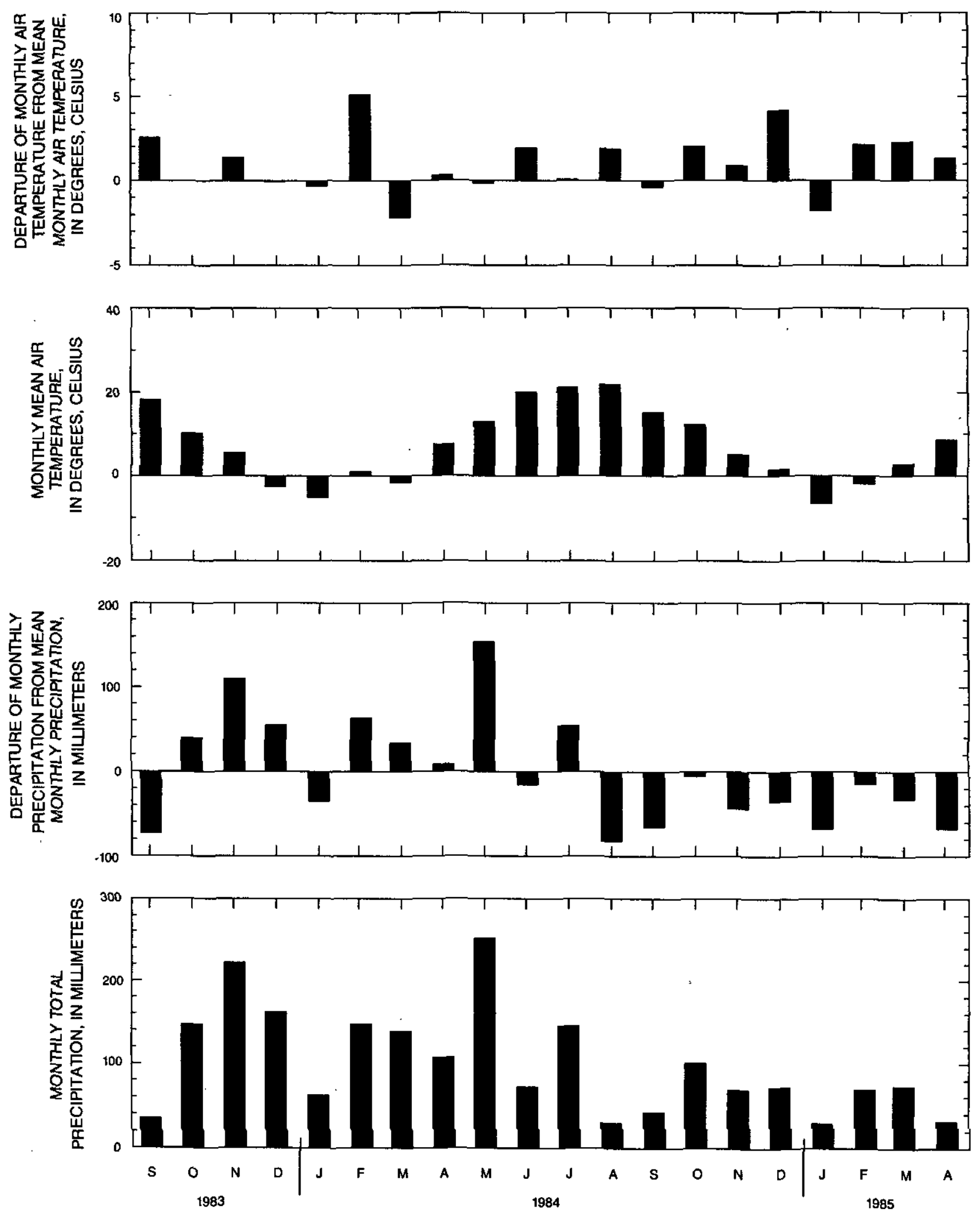

Figure 2. Monthly total precipitation and monthly mean air temperature at National Weather Service station in Worcester, Mass., for September 1983 through April 1985 and the departures from the mean monthly precipitation and air temperature for base period 1951-80. 
anticyclonic system (high-pressure area) is associated with fair weather (no precipitation); whereas the cyclonic system (low-pressure area) and the advancing frontal boundary system are associated with inclement weather (cloudy, commonly with precipitation). Most of the precipitation in Massachusetts comes from the latter two systems which, in this study, were subdivided into four storm types: cyclones into oceanic and continental types, and frontal boundary advances into warm and cold fronts. Criteria used to identify each of these storm types were adapted from Walker (1985). Warm-front storms were dropped from the analysis and are not discussed in detail in this section because precipitation from only three warm-front storms was sampled during the study period.

Microfilm of surface synoptic-scale weather maps of North America and the northern hemisphere were used to track storm systems with time in order to categorize the storm systems sampled as to storm type. The surface-level weather maps were prepared at 3-hour intervals by the National Weather Service National Meteorological Center and were archived on $35-\mathrm{mm}$ microfilm by the National Climatic Data Center in Asheville, N.C. The surface-level weather maps include (1) national and State boundaries that indicate the geographic location of high- and low-pressure centers and warm and cold fronts, and (2) site-specific weather data, such as wind speed and direction, as well as air and dew-point temperatures.

Weather systems in the northern hemisphere usually move west to east in response to the rotation of the Earth. This flow of air is called the prevailing westerlies. In the northern hemisphere, the Earth's rotation is counterclockwise (as viewed from the North Pole), and it imparts a right-turning effect (Coriolis force) on the atmosphere or on any other fluid, such as water draining from a bathtub or circulating in the oceans. This force is zero at the equator and increases to a maximum at the North Pole. In addition, this counterclockwise rotational circulation of air about northern temperate latitudes imparts a regional circulation pattern that is specific to high- and to low-pressure areas. For a highpressure area, the air moves away from the center of highest pressure in a clockwise direction; for a lowpressure area, the air moves toward the center of lowest pressure in a counterclockwise direction. Thus, air flows from areas of high pressure to areas of low pressure, wind being the physical manifestation of that airflow.

Precipitation released by the storm types described in this report results from the collision of cold and warm airmasses. Each of these airmasses has a distinct temperature, water content, and wind speed and direction. Differences in temperature and water content cause density contrasts between airmasses that restrict mixing. For instance, warm, moist air is lighter (less dense) than cold, dry air. When airmasses collide, the warmer, less dense air is displaced upward over the cold air, and mixing is minimal. The reduction of atmospheric pressure as the warm air is elevated causes large-scale adiabatic cooling within the warm air. Clouds are formed when the condensation level is reached because cooling within the warm air has lowered temperature to the dew point. If there is sufficient moisture in the warm air before lifting, a thick layer of clouds will develop and precipitation will result. This precipitation usually has to fall through 900 to $1,500 \mathrm{~m}$ of cold air beneath the cloud deck before reaching land.

Precipitation is maintained by a continuous influx of warm, moist air to the cloud base. Initially, moist air develops in the layer of the atmosphere closest to the Earth, the layer to which moisture is transferred from the Earth's surface by evaporation and transpiration. In eastern North America, the primary source of moisture to this layer is the Atlantic Ocean from the tropical water in the Gulf of Mexico to the subtropical water off the eastern seaboard (fig. 3). This warm, moist aircommonly called tropical maritime air-flows northward over the eastern United States, accumulating additional moisture from soil, vegetation, lakes, ponds, and rivers.

Cold air flows to the eastern United States from Canada and the western North Atlantic Ocean. The Canadian air, called continental polar air, is cold and dry. It flows southeastward from Canada, entering the United States anywhere from Montana to New York State. The North Atlantic cold air, called maritime polar air, is cool and fairly moist. It flows westward off the Atlantic Ocean and is mainly a component of weather systems in New England during winter cyclones. 


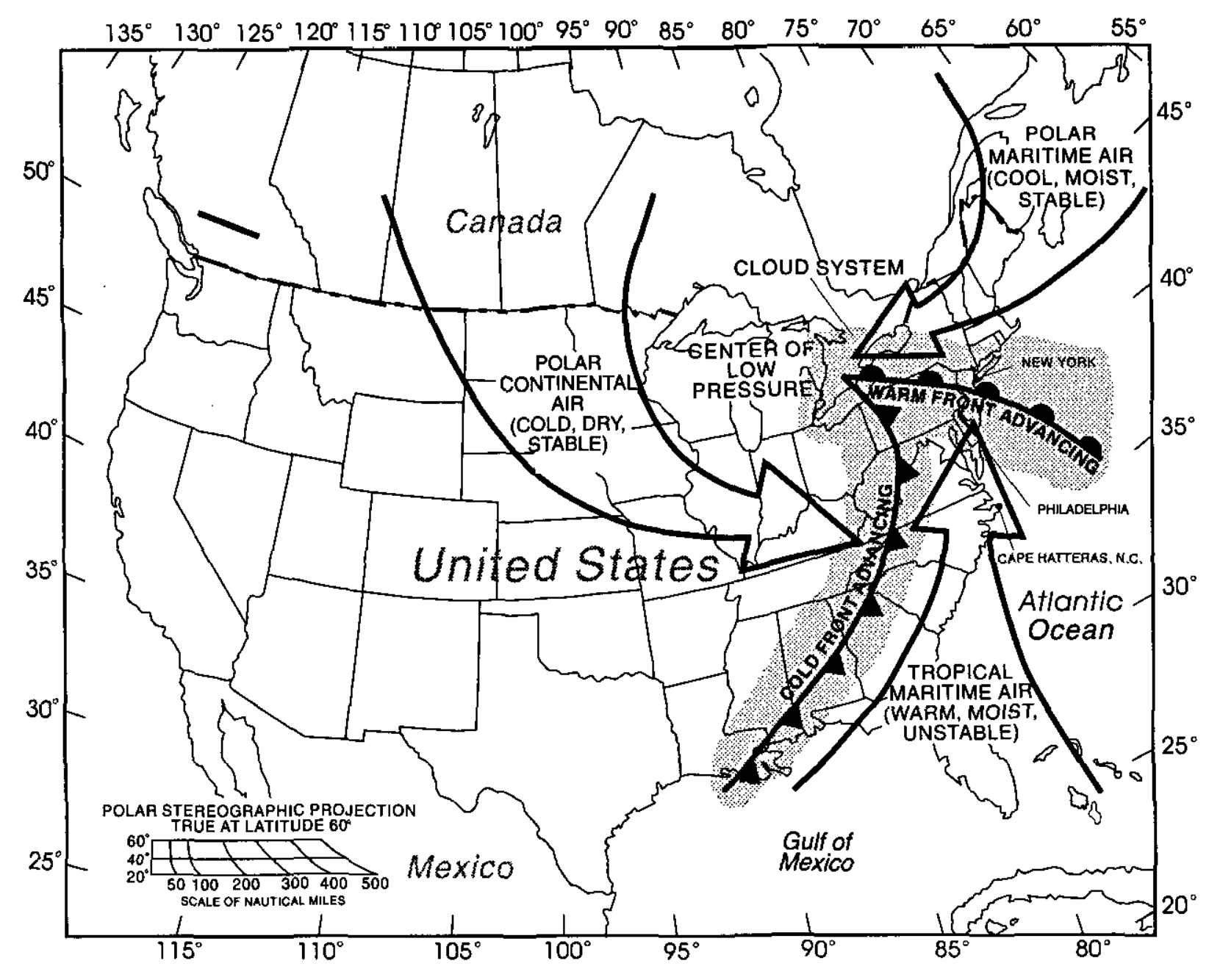

Figure 3. Typical configuration of a cyclone affecting the northeastern United States.

\section{Characteristics of Cyclones}

In the Northern Hemisphere, a cyclone is defined as any counterclockwise circulation of air around a lowpressure center (fig. 3). This center usually is near the northwest quadrant of the cyclone's cloud mass. An advancing warm front extends generally east from the low-pressure center; whereas an advancing cold front extends generally south. Precipitation usually falls along both frontal boundaries, although more precipitation is associated with the advancing warm front than the advancing cold front. These frontal boundaries separate three airmasses - a retreating cool airmass, an advancing warm airmass, and an advancing cold airmass-each having a distinct wind direction and speed, temperature, and moisture content. The retreating cool, moist air is usually north and northeast of the low-pressure center, the warm, moist air is usually southeast (on the leading side) of the low-pressure center, and the cold, dry air is usually on the western (trailing) side of the low-pressure center, as shown in figure 3. On weather maps, the separation between the retreating cool air and the advancing warm air is shown as an advancing warm front, and the separation between the advancing cold air and the advancing warm air is shown as an advancing cold front. Cyclones generally move northward to northeastward. The counterclockwise circulation of air in the system causes each frontal boundary to move slowly in a counterclockwise direction around the center of low pressure, the advancing warm front usually moving slower than the advancing cold front. 
Precipitation is released from a cyclone because the same basic process operates at each set of advancing frontal boundaries: condensation of moisture within the warm, moist airmass as it is forced upward into the atmosphere when it meets a colder airmass. Because of density differences between airmasses, the warm, moist air is forced up and over the denser cold air, no matter which airmass is advancing. At the advancing warmfront boundary (fig. 4A), warm, moist air flows up and over the retreating cool air; whereas at the advancing cold-front boundary (fig. $4 B$ ), the cold air forces the warm, moist air up as the cold front advances. The source of moisture at both frontal boundaries is the same warm, moist air, but the cool airmass ahead of the advancing warm front is completely different from the cold airmass behind the advancing cold front. Thus, precipitation originates in one warm airmass, but precipitation falls through two distinct cold airmasses that enter the cyclone from different areas.

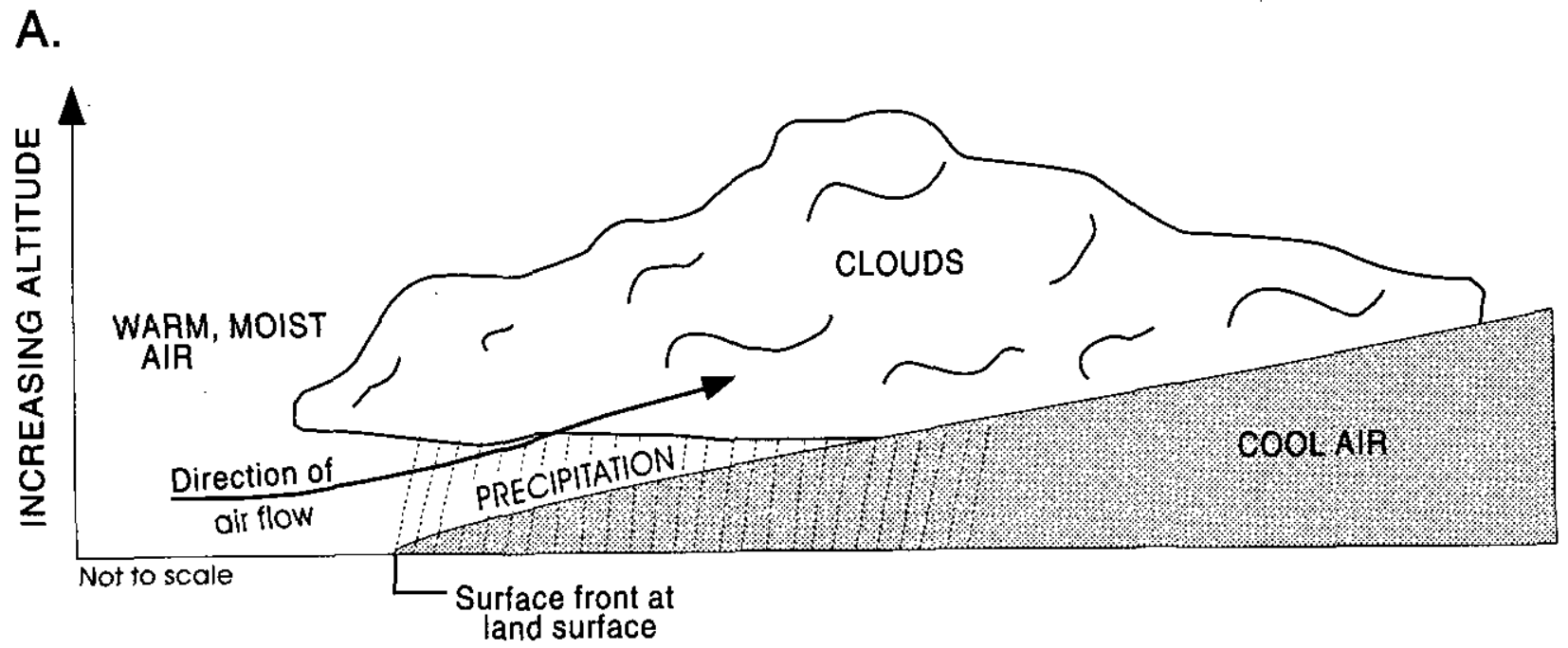

B.

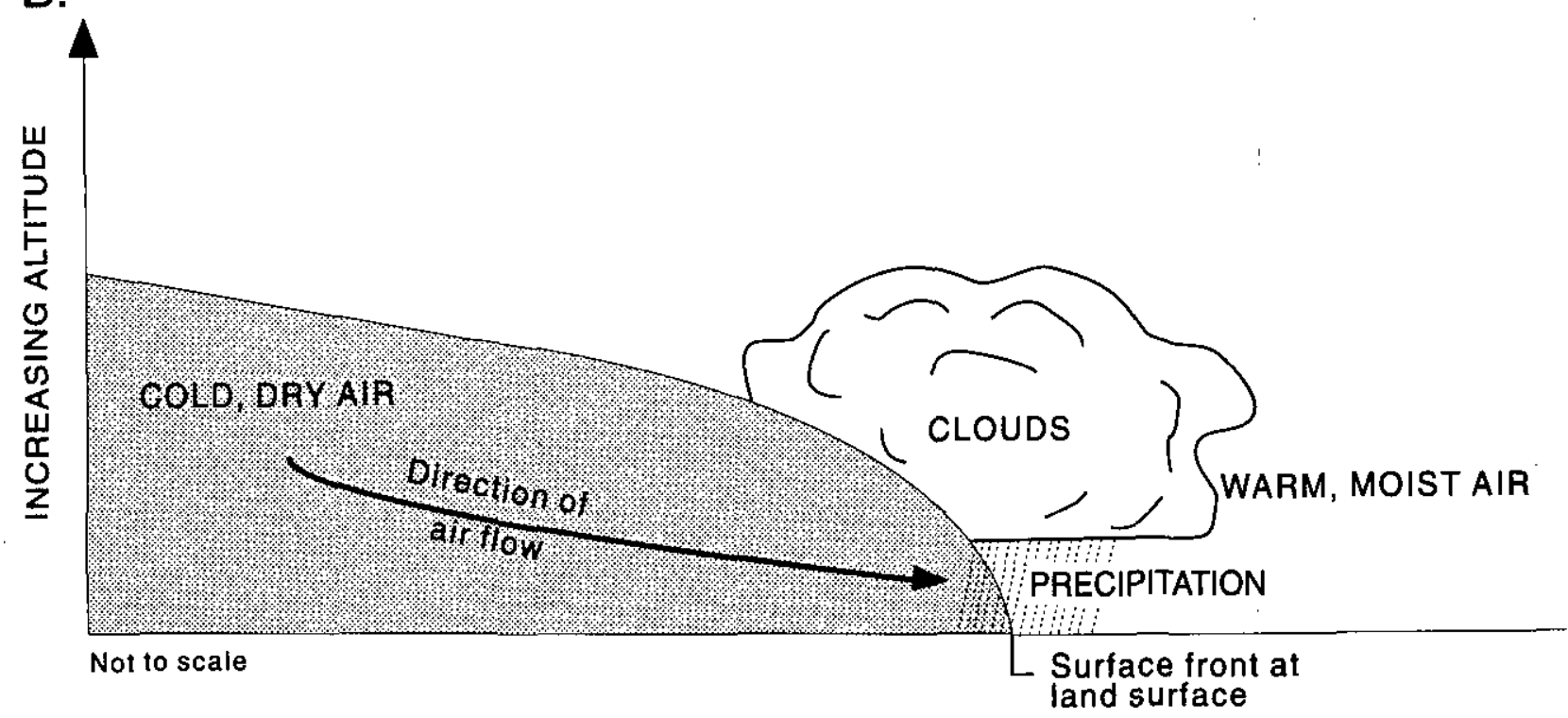

Figure 4. Generalized vertical sections through advancing $(A)$ warm and $(B)$ cold fronts. 


\section{Definition and Description of Common Storm Types}

A number of physical characteristics may be used to classify common storm types. Consistent definitions and descriptions must be established for the common storm types for a reliable analysis of the relation between precipitation quality and storm type. The definitions should be based on relatively simple meteorological characteristics for which data are available for nearly all storms during the sampling period. The definitions of oceanic-cyclone, continental-cyclone, and cold-front storms applied in this study are presented in the following sections.

\section{Oceanic Cyclone}

An oceanic cyclone, as defined in this study, has a low-pressure center that passes to the south and east of the sampling site. Throughout the storm, the sampling site is surrounded by the cool air on the north side of the advancing warm front. At land surface, neither frontal boundary passes over the site; however, higher in the atmosphere, the warm, moist airmass flows over the site. Precipitation at the site results from the cooling of the advancing warm air as it is lifted higher into the atmosphere by the retreating cool air.

An oceanic low-pressure center forms either along the Atlantic coast between Cape Hatteras, N.C., and Philadelphia, $\mathrm{Pa}$., or farther east in the Atlantic Ocean. Those low-pressure centers that form in the coastal waters track northeastward up the coast. Near Philadelphia, these storms veer to the northeast, skirting southern New England and Long Island. The oceanic cyclones produce precipitation from warm, moist air originating over the subtropical water off the eastern seaboard. The cool air lying just to the north of the cyclone's advancing warm front is polar maritime air flowing westward from the Atlantic Ocean just off the New England coast. Because the warm air that is the source of precipitation and the cool air through which this precipitation must fall are of oceanic origin, the chemical composition of precipitation from oceanic cyclones is similar to the composition of seawater (chloride, sodium, sulfate, magnesium, calcium, and potassium). Further, because of the oceanic origin of the airmasses forming oceanic cyclones, precipitation from such storms has relatively small amounts of those constituents commonly found in air that flows over land (for example, nitrates and metals).

\section{Continental Cyclone}

A continental cyclone, as defined in this study, has a low-pressure center that passes to the west and north of the sampling site. This movement causes three separate airmasses (cool, warm, and cold) and two frontal boundaries (advancing warm front and advancing cold front) to pass over the site. The frontal boundaries denote the separation of three airmasses. Precipitation at the sampling site results from the lifting of the warm airmass into the atmosphere, first by the cool air then by the cold air.

Continental cyclones usually form in the Midwestern United States and draw in air from various parts of the continent. The low-pressure center generally moves north to northeast, passing west of Massachusetts. If the storm forms west of the Appalachian Mountains, then the warm air flowing into the system from the south flows northward from the Gulf of Mexico. However, if the storm forms over the coastal plain east of the Appalachian Mountains, then the warm, moist air will be drawn in from the subtropical water of the Atlantic Ocean off the east coast. This air will in turn flow over the northeastern metropolitan areas anywhere from northern Virginia to New York City as the low-pressure center travels northward. Some storm systems formed on the west side of the Appalachian Mountains will cross the mountains during their northward movement. Taking this path, the continental cyclone taps two sources of warm, moist air: tropical water off the Gulf of Mexico and subtropical water off the east coast. The two other sources of air for this type of storm system are the cool, moist air on the north side of the advancing warm front and the cold, dry air on the west side of the advancing cold front. The cool, moist air flows westward from the Atlantic Ocean; the cold, dry air flows southeastward from Canada.

Precipitation produced by a continental cyclone is caused by (1) lifting of the northerly advancing warm, moist air by the retreating cool, polar maritime air flowing in from the Atlantic Ocean off the New England coastline, and (2) lifting of the western edge of the same warm airmass by the trailing cold Canadian air flowing eastward from over the upper Midwest or New York State. The warm, moist air for this storm type flows 
either northward over the northeastern metropolitan areas or eastward over the western side of the Appalachian Mountains. Both areas are highly urbanized and industrialized, and large amounts of fossil fuels are consumed for electric energy and automobile propulsion. Burning of fossil fuels produces an atmosphere containing pollutants that include sulfates and nitrates, as well as trace amounts of lead from automobile emissions. The cold air flowing southward from Canada picks up similar pollutants as it moves over the heavily industrialized and urbanized areas around the Great Lakes and therefore is similar in chemical composition to the warm, moist air (Munger and Eisenreich, 1983).

The only airmass feeding a continental cyclone storm that has not moved over land is the cool, moist air ahead of the advancing warm front. Because this air flows inland off the Atlantic Ocean, it contains chemical constituents common to seawater. However, if this air flows over greater Boston (fig. 1), then sulfates and nitrates common to air over highly urbanized and industrialized areas would be present. Therefore, the chemical composition of precipitation from this storm should reflect the chemical composition of urban and industrialized air because much of the air contributing to this storm has recently traveled over urban and industrial areas prior to the onset of precipitation. Precipitation should be high in nitrates, sulfates, and hydrogen ions (commonly associated with nitrates and sulfates) and low in other common chemical constituents, such as sodium, chloride, and magnesium.

\section{Cold Front}

In contrast to the cyclones described above, a cold-front storm has only one frontal boundary causing precipitation and usually no low-pressure center. If there is a low-pressure center, it is either extremely weak or far enough away from the sampling site that there is little effect on precipitation quality at the sampling site.

Most cold fronts are polar continental air moving southward out of Canada interacting with tropical maritime air moving northward from the Gulf of Mexico or subtropical air flowing northward along the east coast. The cold air can follow the path taken by the cold front (advancing) segment shown in figure 3, or it can move directly southward from Canada, colliding with warm air flowing northward from the Gulf of Mexico.

Precipitation caused by frontal advances depends on several factors: the stability of the warm air being lifted, the temperature and moisture content of the warm air, and the slope of the advancing frontal boundary. If the warm air is stable, then steady and widespread precipitation will result, but if the air is unstable, then locally intense narrow bands of precipitation with thunderstorms and high winds will result. In the warm months (May through September), the air probably will be unstable, and the vertical distribution of temperature will be such that an air parcel, if lifted by convective solar heating, will continue moving up without any further external force being applied. Thunderstorms and turbulent air are the outward manifestation of unstable air. High summer temperatures enable air to contain large quantities of moisture, so a small decrease in air temperature at a frontal boundary will cause a relatively large amount of moisture to condense.

The slopes of the frontal boundaries between warm and cold air differ considerably. Advancing cold-front slopes range from 1:25 to $1: 100$, whereas advancing warm-front slopes range from 1:100 to 1:400 (Bras, 1990 , p. 110). The speed with which a cold front advances determines the frontal slope, and the degree of stability of the warm, moist air ahead of the front determines the intensity and area of the resultant precipitation. Fast-moving cold fronts have steep frontal slopes. When warm air ahead of a rapidly advancing cold front is stable, then widespread precipitation with light to moderate intensities will fall at and ahead of the advancing frontal boundary, the heaviest precipitation being in the immediate area of the front (fig. $5 A$ ). If the warm air ahead of a rapidly advancing cold front is unstable, then precipitation will be intense, probably with thunderstorms along the frontal boundary (fig. 5B). 

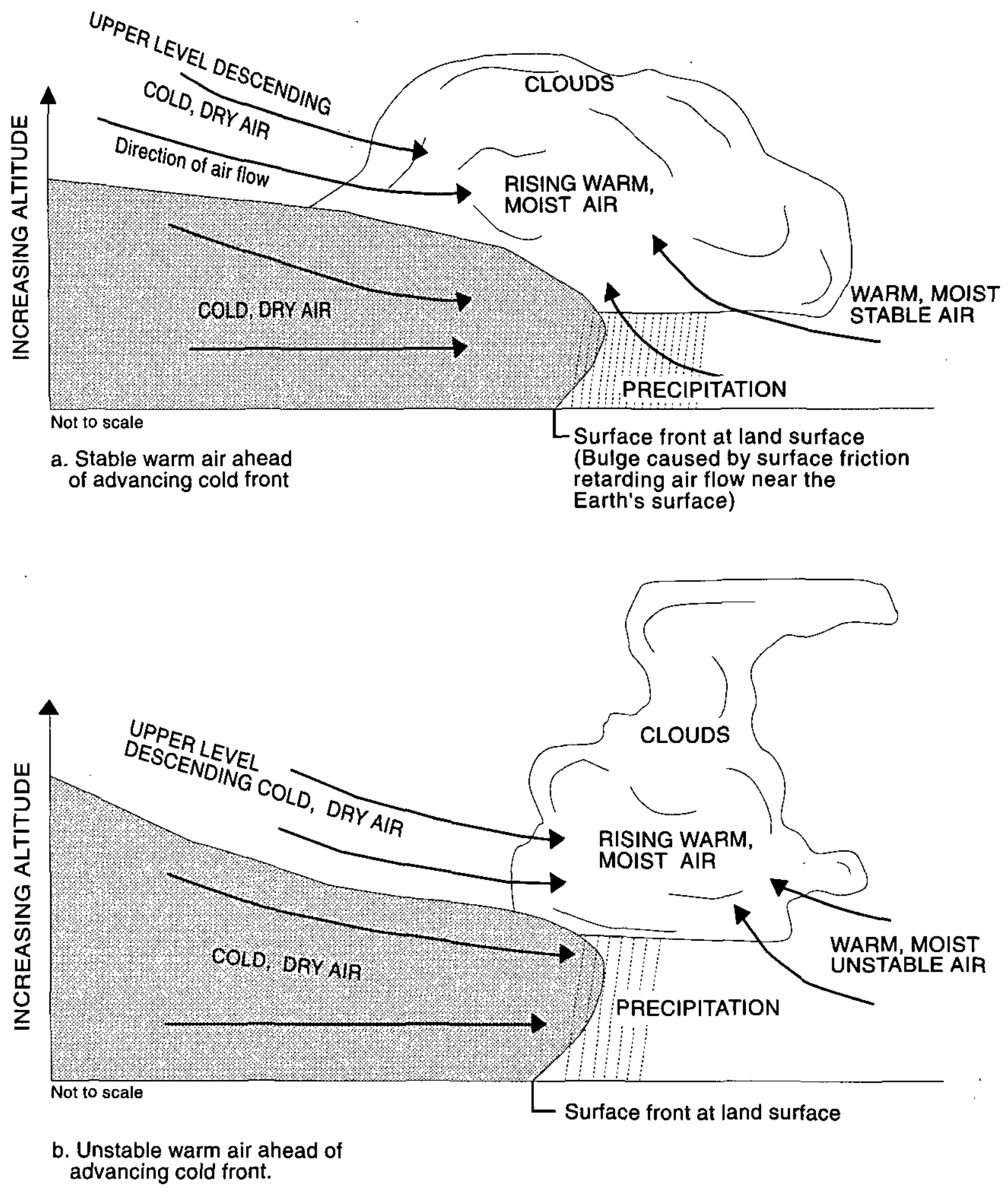

Figure 5. Typical sections through rapidly advancing cold fronts colliding with warm, moist air. 


\section{METHODS OF DATA COLLECTION AND ANALYSIS}

This study involved the collection of precipitation samples from specific storms and analysis of (1) the storm samples collected to determine relations between precipitation quality and storm type, and (2) weekly precipitation samples collected by the NADP to determine chemical-constituent concentrations and loads deposited across Massachusetts. Data collection required installation of special equipment at representative locations in the State. The equipment used and site-selection criteria applied are described below. Statistical tests applied to determine relations between precipitation quality and storm type and the procedures applied to compute seasonal and annual constituent concentrations and loads also are described.

\section{Data Collection}

Because the goal of this study was to relate precipitation quality to storm type and to infer from these relations the contributions of natural and anthropogenic sources to precipitation quality in Massachusetts, sampling sites were chosen so as to minimize effects of local pollutant sources so that general conditions statewide could be evaluated. Further, to obtain valid results, special precipitation-quality sampling equipment and great care in sample handling and analysis were required.

\section{Site-Selection Criteria and Sampling Sites}

The data-collection sites were selected according to guidelines published by the NADP network (Semonin and Volchok, 1978, 1979). Key guidelines from the NADP manuals are listed below. Items 1-5 refer to siteselection criteria, and item 6 refers to equipment installation procedures.

1. No moving sources of pollution, such as coming from routine air, ground, or water traffic, should be within $100 \mathrm{~m}$ of the site.

2. No surface storage of agricultural products, fuels, or other foreign materials should be within $100 \mathrm{~m}$ of the site.

3. No continuous sources of pollution should be within $50 \mathrm{~km}$ in the direction of the mean wind direction for the site or within $30 \mathrm{~km}$ in any other direction.
4. The precipitation-quality sampler should be installed over undisturbed land, preferably grass covered, with no objects within $5 \mathrm{~m}$ of the sampler.

5. No object should project onto the precipitationquality sampler with an angle greater than $30^{\circ}$ from the horizontal. Particular attention should be given to overhead wires.

6. The precipitation-quality sampler should be mounted in an east-west orientation with the wet bucket to the west.

The site at Princeton was in a typical rural, inland environment and the site at Truro on Cape Cod was in a typical rural, coastal environment. In addition, the area immediately surrounding these sites was not developed during the data-collection period. This ensured that chemical data collected at each site would, as nearly as possible, represent rural conditions unaffected by local anthropogenic sources but subject to regional anthropogenic sources of chemical constituents in precipitation.

\section{Princeton Sampling Site}

The site at Princeton was at the Massachusetts Audubon Society Wachusett Meadow Wildlife Sanctuary. Access was over an improved asphalt road that ends in the Sanctuary, thus limiting vehicular traffic to the site. The sampling equipment was near the center of the large upper hay field and was enclosed within a $1.2-\mathrm{m}-$ high fence. The field was mowed twice a year and the hay harvested for animal feed. The equipment enclosure was about $60 \mathrm{~m}$ from the nearest objects (trees) and 1.3 $\mathrm{km}$ from the nearest secondary highway, State Route 62. Within the enclosure, a Geotech ${ }^{1}$ Model 0650 Electronic Wet/Dry Precipitation Collector and a Belfort 5-780 Series Universal Recording Rain Gage were mounted on separate wooden bases so that rims of the collector buckets and rain-gage funnel were about $2.1 \mathrm{~m}$ above land surface. The wet/dry collector is similar to collectors in the NADP network and the USGS National Trends Network. The altitude of the bucket and funnel rims was about $323 \mathrm{~m}$. This altitude was interpolated from the 7.5-minute (1972) Wachusett Mountain, Mass., topographic quadrangle map. The collector and

\footnotetext{
${ }^{1}$ Any use of trade, product, or firm names in this publication is for descriptive purposes only and does not constitute endorsement by the U.S. Government.
} 
rain gage were operated with DC-power sources. No local sources of pollution, such as from storage of agricultural products or wood-burning stoves, were within $100 \mathrm{~m}$ of this site, and the nearest major city, Worcester, is $16 \mathrm{~km}$ to the south-southeast (fig. 1).

\section{Truro Sampling Site}

The site at Truro was in a small clearing used by the National Park Service (NPS) for part of the Cape Cod National Seashore Atlantic Coast Laboratory and for the NADP precipitation collector. Access to the area was restricted by the NPS, and vehicles entered by a narrow asphalt road. The USGS sampling equipment was near the center of the clearing. A vacant one-story building and the NADP collection equipment were within the cleared area, which was surrounded by a 2.4$\mathrm{m}$-high chain link fence. Scrub pines 3 to $5 \mathrm{~m}$ tall were outside the fenced area.

The USGS installed a Geotech Model 0650 Electronic Wet/Dry Precipitation Collector on a wooden base so that the rim of the collector buckets was about $2.1 \mathrm{~m}$ above land surface. The altitude of the bucket rims was about $40 \mathrm{~m}$, as interpolated from the 7.5minute (1972) Wellfleet, Mass., topographic quadrangle map. This equipment, operating on AC power, was placed in the center of the open area about $15 \mathrm{~m}$ from the NADP equipment and vacant building and about $30 \mathrm{~m}$ from the fence. Precipitation amounts for all storms were obtained from the NADP Belfort rain gage, which was identical to the gage at Princeton. Patches of grass, small plants, and low-lying scrub pines were scattered among areas of undisturbed sand within the enclosure; however, no part of the building or the surrounding scrub pines projected onto the collector buckets at an angle greater than $30^{\circ}$ from the horizontal.

The nearest major highway (about $0.8 \mathrm{~km}$ to the west) is State Route 6, known locally as the mid-Cape highway. The Atlantic Ocean is $1.6 \mathrm{~km}$ to the east, and Cape Cod Bay is $4.5 \mathrm{~km}$ to the west. No local sources of pollution, such as from storage of agricultural products or wood-burning stoves, were within $100 \mathrm{~m}$ of this site. The closest source of continuous emissions was a coalfired powerplant at the east end of the Cape Cod Canal in Sandwich, about $45 \mathrm{~km}$ southwest of the collector (fig. 1).

\section{Equipment Description}

The Geotech precipitation collector contained two buckets - one to collect precipitation (wetfall) and the other to collect dry particulate deposition (dryfall)and a precipitation (rain and snow) sensor. This sensor triggered a motor-driven lid that moves back and forth between buckets, covering the wetfall bucket during dry periods and the dryfall bucket during precipitation.

Collection buckets were made of high-density white polyethylene with a capacity of about $16.1 \mathrm{~L}$. On the underside of the lid, a protective seal made of a polyurethane foam pad enclosed within a polyethylene sheet allowed for a tight seal between lid and bucket, ensuring the integrity of bucket and sample. The seal reduced the possibility of changes in constituent concentration because of evaporation from the wetfall bucket during dry periods after precipitation. It also kept dryfall from entering and contaminating the precipitation sample. Likewise, the seal prevented precipitation from entering and contaminating the dryfall bucket during precipitation.

The precipitation sensor consisted of a heater plate and a metal grid above it that serve as the two polarities of an electric circuit. The plate and grid were separated by about $1 \mathrm{~mm}$ of airspace. The electronics within the control box were sensitive enough to detect the passage of electrical current from plate to grid when bridged by a water droplet whose specific conductance is as low as 1 to $3 \mu \mathrm{S} / \mathrm{cm}$ at $25^{\circ} \mathrm{C}$. When a water droplet completed this circuit, the wet bucket was uncovered and a heater turned on beneath the heater plate to evaporate the water droplet. When evaporation was completed, the circuit opened again, causing the lid to move from the dry bucket to cover the wet bucket. As long as the rate of precipitation onto the sensor exceeded the rate of evaporation from the sensor, the grid-to-plate circuit was complete and the wet bucket was exposed to collect precipitation. During the winter, however, snow had to melt before the grid-to-plate circuit was completed. To melt snow, the sensor unit contained a temperature sensor that monitors the surface temperature of the heater plate in order to maintain that temperature at some preset value above freezing $\left(0^{\circ} \mathrm{C}\right)$. Temperature sensors on both Geotech units were set between 5 and $6^{\circ} \mathrm{C}$. A 13$\mathrm{mm}$ high piece of plastic was placed around the sensor in winter so that snow may reach the sensor through the grid plate and that the snow reaching the sensor may be protected (shielded) from the high winds that often 
accompany snowstorms. This was done near the end of the data-collection period because several snowfalls were not sampled earlier in the study, because of wind effects.

Precipitation amounts and timing of storms were recorded on a Belfort Universal Rain Gage. This weighing-type device was configured to (1) collect as much as $305 \mathrm{~mm}$ of precipitation and (2) record the collection rate on an 8-day chart. This configuration allowed the starting and ending times, as well as precipitation amounts, to be determined to the nearest 0.5 hour and $0.25 \mathrm{~mm}$, respectively.

\section{Sample-Collection and Chemical-Analysis Procedures}

Precipitation samples were removed from the Geotech precipitation collector as soon as possible after the precipitation ended, usually within 1 day. At Truro, an observer (1) removed the bucket from the collector after each event, (2) transferred the contents to new plastic polyethylene bottles that had been triple rinsed with distilled water, (3) packed these bottles in ice, and (4) shipped the bottles in a cooler by overnight mail to the USGS Boston, Mass., office for further processing. Samples at Princeton were collected and driven to Boston. Occasionally, for multiple storms on the weekend at Princeton, the wet bucket of the collector was changed, covered, and stored in a dark cool place by a local observer until picked up by USGS personnel on the following Monday. This procedure prevented contamination of a storm sample by subsequent precipitation and minimized any changes in nitrogen speciation and $\mathrm{pH}$ because of the longer time between collection and processing for samples from weekend storms.

The bucket and cover were cleaned according to the following schedule. After every third storm, the polyethylene sheet beneath both lids of the collector was washed with distilled water and wiped dry with laboratory-grade paper wipes to prevent contamination between storms. The interior surfaces of the white polyethylene buckets used to collect precipitation samples and the cover used to protect the sample during transport were cleaned with a combination of laboratory-grade detergent, water, and paper wipes. The cover protected the integrity of the bucket and contents whether empty or containing a sample when the bucket was not in the collector. The texture of the paper wipes was not so abrasive as to scratch the interior surface of the bucket, yet it was abrasive enough to be an effective cleaning agent. Detergents were thoroughly rinsed from the buckets with hot tap water; the buckets were then triple rinsed with a commercially available distilled water and air dried at prevailing room temperature. Once dry, the buckets were covered and stored for later use.

Precipitation samples were processed in the USGS field laboratory unit in Boston before shipment by airmail to the USGS laboratory in Atlanta for chemical analyses. Processing consisted of measurements of specific conductance and $\mathrm{pH}$ on the untreated water, followed by filtration of the remaining sample and the addition of appropriate preservatives. After midOctober 1984, all samples from Princeton were weighed to determine the volume of sample. If the sample could not be processed on the day of arrival, it was stored in a refrigerator at about $4^{\circ} \mathrm{C}$. Samples were not stored longer than 4 days before processing.

Specific conductance and $\mathrm{pH}$ were measured on a small aliquot of untreated water sample. To conserve sample water, the lab technician poured about $85 \mathrm{~mL}$ into a small plastic cup that was discarded after both measurements were completed. Specific conductance was measured by use of a temperature compensating Electronic Switchgear Type MCI (Mark IV) Conductivity Measuring Bridge coupled with a Yellow Springs Instrument Company Glass (PYREX) Dip Conductivity Cell with a 0.1 cell constant. After that measurement, the same aliquot was then used for a $\mathrm{pH}$ measurement by use of a temperature compensating Orion 401 Analog Portable Specific Ion Meter or Orion 701 Digital Specific Ion Meter with an Orion Combination $\mathrm{pH}$ Electrode filled with Orion's low ionic-strength solution. Calibration of the conductance meter was checked periodically with standards that bracketed values obtained from the precipitation samples. These standards were obtained from the USGS laboratory system. Each day, the $\mathrm{pH}$ meter was calibrated with commercially available $\mathrm{pH}$ standards and periodically checked against a low-ionic-strength $\mathrm{pH}$ solution, usually about $\mathrm{pH} 4$, obtained from the USGS laboratory system. The $\mathrm{pH}$ obtained during this check was always within 0.05 units of the reported $\mathrm{pH}$ of the low ionic-strength solution.

Precipitation samples shipped in polyethylene bottles to the laboratory for chemical analysis were first filtered through a $47-\mathrm{mm}$-diameter polycarbonate 
membrane filter with a $0.4-\mu \mathrm{m}$ pore size to remove any particulate matter. Different types of polyethylene bottles and treatment/preservation methods were used, depending on the specific chemical constituents requested in the analysis. For example, water tested for silica and the following constituents-aluminum, antimony, arsenic, barium, beryllium, cadmium, calcium, chromium, cobalt, copper, iron, lead, lithium, magnesium, manganese, molybdenum, nickel, potassium, selenium, sodium, strontium, and zinc-was placed in semitransparent bottles that had been prerinsed with highly purified nitric acid. Highly purified concentrated nitric acid was added to the filtrate on the basis of $1 \mathrm{~mL}$ of acid per $500 \mathrm{~mL}$ of filtrate to lower the $\mathrm{pH}$ to less than 2 to ensure that these constituents remained in solution between bottle filling and chemical analyses at the USGS laboratory in Atlanta. Water analyzed for ammonium, orthophosphate phosphorus, and phosphorus was placed in a brown bottle, preserved with a mercuric chloride tablet, and chilled to about $4^{\circ} \mathrm{C}$. Water analyzed for other chemical constituents such as boron, bromide, chloride, fluoride, nitrate, sulfate, and vanadium was placed in semitransparent bottles with no additional treatment. All polyethylene bottles except those prerinsed with nitric acid by the manufacturer were triple rinsed with commercially available distilled water and as much as $100 \mathrm{~mL}$ of filtrate.

Common chemical constituents were determined from one of three USGS laboratory schedules and common and scarce trace-element constituents from one of two laboratory schedules. Trace elements are commonly defined as elements that always or nearly always are found at concentrations less than $1.0 \mathrm{mg} / \mathrm{L}$ (Hem, 1985, p. 129). Common trace elements refer to those commonly detected in stream-water samples, such as iron, lead, and zinc, whereas scarce trace elements refer to those occasionally detected in water samples, such as chromium, nickel, and vanadium. This suite of trace elements was selected to determine which elements were dominant in precipitation after a literature search indicated that certain ones (such as copper, iron, lead, and zinc) would be found in low concentrations and others (such as arsenic, chromium, nickel, and vanadium) might or might not be found even though these constituents are prevalent in coal and certain ores used in smelters. Each schedule lists the analytical method and field treatment procedure required for each constituent in that schedule. Occasionally, analysis for a specific chemical (usually a trace element) was requested as an add-on to a laboratory schedule. The procedure for the add-on was followed when the sample volume was insufficient to run another schedule. The most common add-ons were analyses for iron and manganese in schedules for the common chemical constituents.

The constituents analyzed for and the schedule selected depended on the volume of filtered water. In general, precipitation of about $1.3 \mathrm{~mm}(85 \mathrm{~mL})$ or more was needed to determine specific conductance and $\mathrm{pH}$, another 3 to $9 \mathrm{~mm}$ ( 200 to $600 \mathrm{~mL}$ ) was needed to determine common chemical constituents listed in table 1 , and an additional $12 \mathrm{~mm}(800 \mathrm{~mL})$ was needed to determine trace elements listed in table 2 . Consequently, only precipitation amounts exceeding $5 \mathrm{~mm}(342 \mathrm{~mL})$ produced sufficient water for chemical analysis; drizzle and light showers produced insufficient volumes even for determination of specific conductance and $\mathrm{pH}$.

As stated, different precipitation amounts necessitated use of various laboratory schedules that did not always determine individual constituents by the same analytical method or to the same detection limit. For each constituent, the detection limit or limits are shown

Table 1. Common chemical constituents applied in the evaluation of precipitation in Massachusetts, 1983-85, and analytical detection limits

[Chemical analysis done by the U.S. Geological Survey Water-Quality Laboratories. Different detection limits resulted because the three laboratory schedules used did not always determine a given chemical constituent by the same analytical method or to the same detection limit]

\begin{tabular}{ll}
\hline \multicolumn{1}{c}{ Chemical constituent } & $\begin{array}{c}\text { Detection limit } \\
\text { (milligrams per liter) }\end{array}$ \\
\hline Calcium & 0.01 or 0.02 \\
Magnesium & 0.01 \\
Sodium & 0.01 or 0.2 \\
Potassium & 0.01 \\
Sulfate & 0.01 or 0.2 \\
Chloride & 0.01 or 0.20 \\
Fluoride & 0.01 \\
Bromide & 0.01 or 0.10 \\
Silica & 0.01 \\
Nitrate, as nitrogen & 0.01 or 0.05 \\
Ammonium, as nitrogen & $0.001,0.002$, or 0.01 \\
Phosphorus, as phosphorus & $0.001,0.01$, or 0.06 \\
Orthophosphate, as phosphorus & 0.001 \\
\hline
\end{tabular}


Table 2. Common and scarce trace elements applied in the evaluation of precipitation in Massachusetts, 1983-85, and analytical detection limits

[Chemical analysis done by the U.S. Geological Survey Water-Quality Laboratories. Different detection limits resulted because the two laboratory schedules used did not always determine a given chemical constituent by the same analytical method or to the same detection limit]

\begin{tabular}{lc}
\hline $\begin{array}{c}\text { Common and scarce } \\
\text { trace elements }\end{array}$ & $\begin{array}{c}\text { Detection limit } \\
\text { (micrograms per liter) }\end{array}$ \\
\hline Aluminum & 10 \\
Antimony & 1 \\
Arsenic & 1 \\
Barium & 2 \\
Beryllium & .5 \\
Boron & 20 \\
Cadmium & 1 \\
Chromium & 1 \\
Cobalt & 3 \\
Copper & .05 or 10 \\
Iron & 3 \\
Lead & .08 or 10 \\
Lithium & 4 \\
Manganese & 1 \\
Molybdenum & 10 \\
Nickel & 1 \\
Selenium & 1 \\
Strontium & .5 \\
Vanadium & 1 or 6 \\
Zinc & 3 \\
\hline
\end{tabular}

in tables 1 and 2 ; however, the less-than values given in some of the tables in this report are higher than the detection limit reported for a given constituent in tables 1 and 2 . This disparity results when the chemical analyst at the laboratory does not have confidence in reporting the constituent to any lower value than shown because of possible interferences from other constituents or chemical compounds in the water sample.

The precipitation capture efficiency of the collector bucket and sensor unit combination was determined with respect to the rain gage for all storms sampled after mid-October 1984 for the Princeton site, but not for the Truro site. Capture efficiencies were used to determine whether the structure of the Geotech precipitation collector adversely affected collection of a total precipitation sample for water-quality analysis and, to a lesser extent, whether the collector lid operated properly during a period of precipitation. Capture efficiencies at
Truro were assumed to be similar to those at Princeton as long as precipitation amounts in the dry bucket were minimal. Capture efficiencies were determined by dividing the measured volume of water in the bucket by the volume of water that should have been in the bucket, as calculated from the depth of water recorded by the rain gage. For the 32 samples at Princeton, capture efficiencies ranged from 36.5 to 119.7 percent for precipitation depths (rain, snow, or mixed rain and snow) ranging from 0.76 to $42.4 \mathrm{~mm}$. Inspection of the capture efficiency and precipitation data indicates that the data were skewed below the mean by storms yielding little water. The six lowest capture efficiencies, 67 percent or less, were for precipitation depths equal to or less than $4.3 \mathrm{~mm}$. However, including the six low capture efficiencies in the data set, the median capture efficiency was 95 percent.

Samples from either site were not sent for chemical analysis if precipitation amounts in the dry collector exceeded 5 to 10 percent of the sum total from both buckets (wet and dry). Aside from outright failure of the motor, sensor, or battery, precipitation in the dry bucket was usually caused by either the insensitivity of the sensor unit to light drizzle or the behavior of dry, winddriven snow. Light drizzle would be evaporated from the heater plate before it could accumulate enough to complete the circuit between the plate and grid; whereas dry, wind-driven snow would blow past the sensor without sticking to the heater plate.

\section{Precipitation-Quality Data Analysis}

Two types of data (precipitation from storm samples and weekly composite samples) were used to describe variations in precipitation quality. Samples of precipitation from specific storms were collected by the USGS to describe the variation in precipitation quality between storms and to relate that variation to storm type. Weekly composite samples of precipitation collected and analyzed by the NADP were used to determine the volume-weighted mean concentrations and chemical loads of various constituents in precipitation on an annual and seasonal basis. Each of these data types is suited to quantify a particular aspect of precipitation quality. To determine the loads of various chemicals falling on the Earth's surface on an annual or seasonal basis, one should sample every storm, but storm data need not be collected for all storms to determine relations between precipitation quality and storm 
type. Composite samples can be used to determine the volume-weighted mean concentration of various constituents in precipitation by year or by season but cannot be used to make conclusions about the range or percentile spread in those chemical concentrations by storm. Furthermore, information available from weekly composite samples is not as accurate as information available from individual storm data regarding the contribution of seawater to precipitation because the ratios of the various constituents in precipitation change from storm to storm and a composite sample contains water from more than one storm. The assumptions and procedures applied to determine (1) relations between storm type and precipitation quality and (2) seasonal and annual constituent loads from weekly composite samples are described in the following sections.

\section{Storm Samples}

Before doing statistical calculations, one must consider the constituent concentrations reported by the laboratory as a value less than the detection limit of the laboratory method used in the chemical analysis. Concentrations were changed to 0 if the detection limit was less than or equal to $0.01 \mathrm{mg} / \mathrm{L}$ for common constituents (table 1) and less than or equal to $0.1 \mu \mathrm{g} / \mathrm{L}$ for trace elements (table 2). Because the nonparametric KruskalWallis test (Conover, 1980, p. 229-237) was used to analyze ranked concentrations, changing concentrations that were less than the detection limit to 0 facilitated the ranking procedure without introducing bias into the analysis. Further, changing concentrations that were less than the detection limit to 0 did not significantly affect the volume-weighted mean concentration and storm-load analysis. Concentrations were changed to one-half of the detection limit if the detection limit was greater than $0.01 \mathrm{mg} / \mathrm{L}$ for common constituents (table 1) and greater than $0.1 \mu \mathrm{g} / \mathrm{L}$ for trace elements (table 2). This value was selected because the mean (and volume-weighted mean) of the observations remains unbiased as long as all measurements between 0 and the detection limit were equally probable and are uniformly distributed (Gilbert, 1987, p. 178). For constituents reported at more than one detection limit, measured concentrations less than the highest detection limit were mixed with concentrations that were changed to one-half of the highest detection limit and both types of data were used in the ranking procedure for the Kruskal-Wallis test. The number of samples recorded as less than the highest detection limit was small and should not have significantly biased the statistical test results. The original less-than values are given in the tables 21 and 22 (at back of report).

In general, samples with concentrations less than the highest detection limits were not discarded because most of the concentrations were extremely small with respect to the range of the remaining concentrations and the number of significant figures to which these concentrations were reported. Thus, retention of these samples increased the information about the distribution of various constituents in precipitation. In addition, these samples were probably not completely void of a given constituent as evident from the small number of samples with concentrations less than the detection limit when compared to the large number of samples with concentrations greater than the detection limit and the range of those concentrations greater than the detection limit.

At Princeton, the statistics reported for chloride and sodium may have been affected by the large number of samples with chloride and sodium concentrations less than the detection limit and the relatively high detection limit $(0.20 \mathrm{mg} / \mathrm{L})$ when compared to the rest of the data. For several trace elements (antimony, arsenic, beryllium, boron, cadmium, chromium, cobalt, lithium, molybdenum, nickel, selenium, and vanadium), few concentrations were greater than the detection limit; therefore, these constituents were not statistically analyzed except to identify how many concentrations were less than or greater than the detection limit.

All $\mathrm{pH}$ data were converted to an hydrogen-ion equivalent concentration before any statistical or load calculations were done. Except for reported maximum, minimum, and quantile values of $\mathrm{pH}$, all $\mathrm{pH}$ 's in this report (that is, ranked means) have been reconverted from equivalent hydrogen-ion concentrations. This conversion also was done for all calculations for the NADP precipitation-quality data.

Constituent loads for each storm sample, in milligrams per square meter or micrograms per square meter, were computed by multiplying the precipitation depth from the rain gage, in millimeters, by the constituent concentration, in milligrams per liter or micrograms per liter, and an appropriate conversion factor. The sum of the loads for a constituent for all storms was divided by the total amount of precipitation for all storms to determine the volume-weighted mean concentration for a constituent. 
Orthophosphate phosphorus exceeded total phosphorus in 30 percent of the samples. Although this is stoichiometrically impossible given that orthophosphate plus polyphosphate plus organic phosphorus equals total phosphorus, this resulted from the measurement error associated with the analytical method used to analyze each of the constituents. Because all phosphorus concentrations were within reasonable ranges with respect to the measurement errors, statistics were computed for dissolved orthophosphate phosphorus and dissolved total phosphorus.

\section{Statistical Analysis for Storm-Type Evaluation}

Statistical analysis was used to test whether different storm types produced equal ranked-mean concentrations or ranked-mean loads of various constituents at Princeton and at Truro. In order to test the null hypothesis that different storm types produced equal concentrations or loads of various constituents at each datacollection site, the nonparametric Kruskal-Wallis test was applied as recommended by Ward and others (1990, p. 98) for comparison of data from multiple sources. The Kruskal-Wallis test (Conover, 1980, p. 229-237) is a nonparametric procedure on rank-transformed data. This test is valuable when neither untransformed nor transformed data can be approximated by a normal distribution. The rank-transformation procedure was done by (1) selecting all concentrations or loads for a given constituent for the three storm types and (2) ranking those data from lowest to highest by assigning rank 1 to the lowest concentration or load, rank 2 to the next lowest concentration or load, and so on. If two or more samples had identical concentrations or loads, the average of the ranks was assigned to each sample. For example, if three samples had the same concentration of a constituent at the 20th lowest concentration, then the samples could be ranked 20,21, and 22 arbitrarily; however, all samples should be given the average rank of 21 . The sum of the set of concentration or load ranks for each storm type were then computed and compared by use of the Kruskal-Wallis test statistic. A significance level of 5 percent was used to reject the hypothesis that the mean constituent concentration or load was equal among storm types.

In the Kruskal-Wallis test, initially significant differences in the means among $k$ independent data sets are checked. If, and only if, the hypothesis of equal means among the $k$ data sets is rejected, Fisher's Least Significant Difference procedure (Conover, 1980, p. 231-236) may be used to determine which pairs of data sets tend to differ. A significance level of 5 percent was used to reject the hypothesis that the mean concentration or load was equal between storm types. Where statistically valid differences in the means of constituents between various storm types were detected, this result was taken as an indication that the storm types were being affected differently by the environmental factors on the land and water surfaces that the storms passed over.

Results obtained from the Kruskal-Wallis test are in terms of the means of ranks; thus, one can make inferences about the equality of means among the three storm types for concentrations or loads of specific constituents without quantifying the concentration or load. To consider the concentrations and loads quantitatively, the ranked means must be reconverted to the appropriate concentrations or loads by comparing the ranked means to the table of ranked and actual values of the characteristic of interest and by interpolating between values where necessary. The transformed values, because they are developed from means of ranks, should be interpreted as medians rather than means.

\section{Statistical Analysis of Concentration Data}

Volume-weighted mean concentrations were computed for chemical constituents detected in the storm samples collected at Princeton and Truro. These volume-weighted mean concentrations for each constituent were determined by summing, for all storms, the product of the constituent concentration and volume of precipitation per unit area and dividing that sum by the sum of the precipitation volumes used to calculate those products. This approach was followed to normalize the differences between constituent concentration and precipitation volume between storms, because no two storms produce identical amounts and compositions of precipitation. For example, light precipitation tends to contain higher concentrations of various constituents than does moderate to heavy precipitation. This can be demonstrated by calculating arithmetic means of all chemical constituents. In addition to the volume-weighted and arithmetic mean concentrations, concentrations at the 10th, 25th, 50th, 75th, and 90th percentiles were calculated for each constituent. 
All pH's were converted to equivalent hydrogenion concentrations before performing any calculation, such as the volume-weighted mean hydrogen-ion concentration, that was then reconverted to an equivalent $\mathrm{pH}$. Computing volume-weighted mean $\mathrm{pH}$ from measured $\mathrm{pH}$ without first converting those values to equivalent hydrogen-ion concentration leads to incorrect means. This is because $\mathrm{pH}$ is expressed in logarithmic scale, and, by definition, the difference in hydrogen-ion activity represented by a change of one unit is tenfold; for instance, $\mathrm{pH} 4$ is 10 times more acidic than $\mathrm{pH} 5$. The mean of logarithmic numbers reduces the effect of this tenfold difference because the arithmetic mean represents equal weights for each logarithmic value. The large differences in hydrogen-ion concentration that can result from different computational procedures can be shown by comparing computations on $\mathrm{pH}$ measurements at Princeton. The arithmetic mean of $\mathrm{pH}$ measurements is 4.34 units, or $46.1 \mu \mathrm{g} / \mathrm{L}$ of hydrogen ion; whereas the mean $\mathrm{pH}$ based on hydrogen-ion concentration is 4.21 units, or $62.6 \mu \mathrm{g} / \mathrm{L}$ of hydrogen ion. The volume-weighted mean of the $\mathrm{pH}$ measurements is 4.58 units, or $26.5 \mu \mathrm{g} / \mathrm{L}$ of hydrogen ion, whereas the average $\mathrm{pH}$ based on the volume-weighted mean hydrogen-ion concentration is 4.46 units, or $34.7 \mu \mathrm{g} / \mathrm{L}$ of hydrogen ion ( 4.46 is the correct $\mathrm{pH}$ to use for acid-load computations).

Microequivalents per liter $(\mu \mathrm{eq} / \mathrm{L})$ were computed from the volume-weighted mean concentrations at each site, as specified by Hem (1985, p. 56), to facilitate graphical comparisons between constituents and between sites. Microequivalents represent chemically equivalent combining weights. For example, if concentrations of sodium and chloride in microequivalents per liter were the same, then the source of both probably would be sea salt; whereas if the concentration of chloride exceeded that of sodium, a source for chloride in addition to sea salt would be probable.

Sea-salt (oceanic) contributions to precipitation quality were determined by averaging the results obtained from multiplying (1) a chloride-based ratio of seawater concentrations (sodium to chloride, sulfate to chloride, magnesium to chloride, calcium to chloride, and potassium to chloride) by the chloride concentration in precipitation samples and (2) a sodium-based ratio of seawater concentrations (chloride to sodium, sulfate to sodium, magnesium to sodium, calcium to sodium, and potassium to sodium) by the sodium con- centration in precipitation samples. Granat (1972) indicated that the predominant source of sodium and chloride in precipitation is from sea spray. Therefore, at coastal sites and for some distance inland, the procedure described above is appropriate. Mean concentrations of the six most common constituents in seawater used in the ratio computations were chloride $(19,000 \mathrm{mg} / \mathrm{L})$, sodium $(10,500 \mathrm{mg} / \mathrm{L})$, sulfate $(2,700 \mathrm{mg} / \mathrm{L})$, magne$\operatorname{sium}(1,350 \mathrm{mg} / \mathrm{L})$, calcium $(410 \mathrm{mg} / \mathrm{L})$, and potassium $(390 \mathrm{mg} / \mathrm{L})(\mathrm{Hem}, 1985$, p. 7). Calculated concentrations of the oceanic constituents in precipitation were not allowed to exceed the concentrations measured in precipitation samples. The difference between the total concentration and concentration from oceanic sources in precipitation samples represents the contribution from non-oceanic sources. In the case of sulfate, its nonoceanic source would be mainly of anthropogenic origin, namely the burning of fossil fuels (Galloway and Whelpdale, 1980). Volume-weighted mean concentrations of each of these constituents were computed by use of the calculated concentration of the oceanic component in precipitation to determine an overall mean of the oceanic contribution to precipitation at each site.

\section{Weekly Composite Samples for Calculation of Annual and Seasonal Concentrations and Loads}

Volume-weighted mean concentrations and loads for seasonal and annual periods were calculated for each constituent in the NADP data base. The volumeweighted mean concentrations were determined by first summing, for each weekly composite sample, the product of the constituent concentration and volume of precipitation per unit area for any given period and then dividing by the sum of the precipitation volumes used to calculate those products. Constituent loads for each weekly sample, in milligrams per square meter, were computed by multiplying precipitation quantity for each week, in millimeters, by the constituent concentration, in milligrams per liter. These weekly loads were then summed to obtain seasonal and annual loads.

Because the NADP data were collected and processed weekly, the beginning and end of a seasonal period was selected to coincide with the weekly sample closest to the calendar date of seasonal change. For example, the summer solstice is on or about June 22; therefore, weekly data beginning on June $22-28,1983$, were included in the first week of the 1983 summer season. Each season constituted 13 weekly composite data sets. 
All concentrations less than the detection limit in the NADP data base were changed to one-half of the detection limit before volume-weighted mean concentrations or loads were computed. The number of the concentrations less than the detection limit was small, and such samples were scattered throughout the data base, except for concentrations of orthophosphate phosphorus. More than 90 percent of the orthophosphate phosphorus concentrations were reported as less than $0.003 \mathrm{mg} / \mathrm{L}$. Therefore, volume-weighted mean concentrations and loads of orthophosphate phosphorus are less reliable estimates than those for other constituents analyzed.

Occasionally, the NADP data base contained periods (1 or 2 weeks) of no chemical data, even though precipitation records indicated that rain or snow had fallen. During those periods, the volume-weighted mean concentration for the season containing that missing record was used along with the precipitation quantity for the entire season (including missing record) to normalize loads over the entire season and obtain a closer estimate of the actual load.

\section{RELATION OF PRECIPITATION QUALITY TO STORM TYPE}

Precipitation quality was compared to storm type to determine if any constituent concentrations or loads could be related to storm type. Constituent concentrations in precipitation are attributed to rainout from the composition of the precipitation-producing airmass and to washout from the airmass through which the precipitation falls. The concentrations of constituents in a precipitation sample are expected to represent, to some extent, the average concentration of those constituents present in the airmasses over a sampling site during the period of precipitation. The airmasses that contribute rainout (the rising warm, moist air) and washout (the cool underlying air) typically have different travel paths, have passed over different parts of the Earth, and have distinctly different chemical compositions. The rainout and washout airmasses may have been subjected to different amounts and types of dust, aerosols, byproducts of combustion, and volatilization from different sources before contributing to the composition of precipitation. Chemical constituents of the precipitation are difficult to assign or apportion to rainout or washout from the results of chemical analysis only.
The relation of constituent concentrations and loads to storm type was statistically analyzed. For many constituents, the analysis indicated no significant difference (at the 5-percent level) between ranked-mean concentrations or loads with respect to storm type. The results of these analyses are discussed separately for the inland (Princeton) and coastal (Truro) sites.

\section{Princeton Sife}

Average intensity of precipitation from the 70 storms sampled at Princeton was $0.94 \mathrm{~mm} / \mathrm{h}$, and no significant difference in intensity was found among storm types (table 3 ). Cold-front storms produced about one-half as much precipitation, $8.1 \mathrm{~mm}$, as did oceanic and continental cyclonic storms, 15.5 and $16.0 \mathrm{~mm}$, because cold-front-storm duration was about one-half that of the cyclonic storms. In contrast, the ranked-mean specific conductance of precipitation, a measure of ionic concentration, was $30 \mu \mathrm{S} / \mathrm{cm}$ at $25^{\circ} \mathrm{C}$ for cold-front storms, slightly less than twice the conductance for oceanic cyclones, $16 \mu \mathrm{S} / \mathrm{cm}$ at $25^{\circ} \mathrm{C}$, and continental cyclones, $19 \mu \mathrm{S} / \mathrm{cm}$ at $25^{\circ} \mathrm{C}$. These differences of volume and ionic concentration offset each other, and the loads of constituents in the precipitation were about equal for the types of storms sampled.

Cold-front storms produced precipitation with higher concentrations of hydrogen ion, $67.0 \mu \mathrm{g} / \mathrm{L}$, than did oceanic cyclones, $34.9 \mu \mathrm{g} / \mathrm{L}$, and continental cyclones, $39.4 \mu \mathrm{g} / \mathrm{L}$ (table 3 ). Hydrogen-ion loads, indicated in table 4 , were affected by storm type. Continental cyclones produced greater hydrogen-ion loads than did the other two storm types. Although the continental cyclones produced hydrogen-ion loads about two times higher than those from cold-front storms, the hydrogenion concentration in cold-front storms was greater than that in the cyclonic storms. This difference is attributed to the cold-front storms' producing about one-half as much water as cyclonic storms, thereby forming less dilute precipitation. The greater concentrations and hydrogen-ion loads in the cold-front storms and continental cyclones reflects the exposure of rainout and washout airmasses of these storms to combustion byproducts over land, which contribute significantly to the acidity of precipitation (Munger and Eisenreich, 1983). Only the washout components of the airmasses in oceanic cyclones commonly cross land and are exposed to combustion by-products. 
Table 3. Ranked-mean precipitation characteristics and constituent concentrations by storm type for Princeton, Massachusetts, 1983-85, and results from the Kruskal-Wallis test of differences among the ranked means

[Significant differences in ranked-mean values among storm types: Five-percent significance level used for the Kruskal-Wallis test. mm, millimeter; $h$, hour; $\mu \mathrm{S} / \mathrm{cm}$, microsiemen per centimeter; ${ }^{\circ} \mathrm{C}$, degree Celsius; $\mu \mathrm{g} / \mathrm{L}$, microgram per liter; $\mathrm{mg} / \mathrm{L}$, milligram per liter. <, actual value is less than the detection limit for the constituent concentration. Do., ditto]

\begin{tabular}{|c|c|c|c|c|c|c|c|}
\hline \multirow{3}{*}{$\begin{array}{l}\text { Precipitation characteristic } \\
\text { or chemical constituent }\end{array}$} & \multicolumn{6}{|c|}{ Storm type } & \multirow{3}{*}{$\begin{array}{l}\text { Significant differences in ranked-mean } \\
\text { values among storm types }\end{array}$} \\
\hline & \multicolumn{2}{|c|}{ Oceanic cyclone } & \multicolumn{2}{|c|}{ Continental cyclone } & \multicolumn{2}{|c|}{ Cold front } & \\
\hline & $\begin{array}{l}\text { Number } \\
\text { of storms }\end{array}$ & $\begin{array}{l}\text { Ranked } \\
\text { mean }\end{array}$ & $\begin{array}{l}\text { Number } \\
\text { of storms }\end{array}$ & $\begin{array}{l}\text { Ranked } \\
\text { mean }\end{array}$ & $\begin{array}{l}\text { Number } \\
\text { of storms }\end{array}$ & $\begin{array}{l}\text { Ranked } \\
\text { mean }\end{array}$ & \\
\hline Precipitation quantity (mm) & 26 & 15.5 & 20 & 16.0 & 24 & 8.1 & Both cyclonic storm types greater than cold-front storms. \\
\hline Precipitation duration (h) & 26 & 20 & 20 & 19 & 24 & 7 & Do. \\
\hline Precipitation intensity $(\mathrm{mm} / \mathrm{h})$ & 26 & .89 & 20 & 1.02 & 24 & .91 & Not significant. \\
\hline $\begin{array}{l}\text { Specific conductance } \\
\left(\mu \mathrm{S} / \mathrm{cm} \text { at } 25^{\circ} \mathrm{C}\right)\end{array}$ & 26 & 16 & 20 & 19 & 24 & 30 & Both cyclonic storm types greater than cold-front storms. \\
\hline pH (standard units) & 26 & 4.5 & 20 & 4.4 & 24 & 4.2 & Do. \\
\hline Hydrogen ions $(\mu \mathrm{g} / \mathrm{L})$ & 26 & 34.9 & 20 & 39.4 & 24 & 67 & Both cyclonic storm types less than cold-front storms. \\
\hline Calcium (mg/L) & 17 & .06 & 18 & .08 & 9 & .08 & Not significant. \\
\hline Magnesium (mg/L) & 17 & .03 & 18 & .03 & 9 & .02 & Do. \\
\hline Sodium (mg/L) & 16 & .11 & 18 & .11 & 9 & .11 & Do. \\
\hline Potassium (mg/L) & 17 & .02 & 18 & .03 & 9 & .03 & Do. \\
\hline Sulfate $(\mathrm{mg} / \mathrm{L})$ & 17 & 1.01 & 18 & 1.34 & 9 & 1.50 & $\begin{array}{l}\text { Cold-front storms and continental cyclones greater } \\
\text { than oceanic cyclones. }\end{array}$ \\
\hline Chloride (mg/L) & 17 & .11 & 18 & .21 & 9 & .20 & Not significant. \\
\hline Fluoride (mg/L) & 16 & $<.01$ & 18 & .01 & 9 & $<.01$ & Do. \\
\hline Bromide (mg/L) & 4 & $<.01$ & 6 & .03 & 3 & $<.01$ & $\begin{array}{l}\text { Cold-front storms and oceanic cyclones less than } \\
\text { continental cyclones. }\end{array}$ \\
\hline Silica $(\mathrm{mg} / \mathrm{L})$ & 10 & $<.01$ & 13 & $<.01$ & 7 & .01 & Not significant. \\
\hline Nitrate, as nitrogen $(\mathrm{mg} / \mathrm{L})$ & 16 & .15 & 18 & .20 & 9 & .23 & Do. \\
\hline Ammonium, as nitrogen $(\mathrm{mg} / \mathrm{L})$ & 16 & .07 & 18 & .11 & 9 & .11 & Do. \\
\hline Phosphorus (mg/L) & 15 & .002 & 13 & .001 & 6 & .001 & Do. \\
\hline $\begin{array}{l}\text { Orthophosphate phosphorus, } \\
\text { as phosphorus (mg/L) }\end{array}$ & 14 & .003 & 14 & .001 & 7 & .004 & Do. \\
\hline Aluminum $(\mu \mathrm{g} / \mathrm{L})$ & 8 & 10 & 6 & 5 & 4 & 10 & $\begin{array}{l}\text { Cold-front storms and oceanic cyclones greater than } \\
\text { continental cyclones. }\end{array}$ \\
\hline Barium $(\mu \mathrm{g} / \mathrm{L})$ & 3 & 13 & 7 & 12 & 5 & 13 & Not significant. \\
\hline Copper $(\mu \mathrm{g} / \mathrm{L})$ & 10 & 1.3 & 8 & 4 & 5 & 3.2 & Continental cyclones greater than oceanic cyclones. \\
\hline Iron $(\mu \mathrm{g} / \mathrm{L})$ & 16 & 4.2 & 15 & 6.2 & 10 & 4.7 & Not significant. \\
\hline Lead $(\mu \mathrm{g} / \mathrm{L})$ & 10 & 1.6 & 8 & 3 & 5 & 3.3 & Do. \\
\hline Manganese $(\mu \mathrm{g} / \mathrm{L})$ & 16 & .5 & 15 & .5 & 10 & 1 & Do. \\
\hline Strontium $(\mu \mathrm{g} / \mathrm{L})$ & 3 & 6 & 7 & .6 & 5 & 6 & Do. \\
\hline Zinc $(\mu g / L)$ & 3 & 9 & 7 & 13 & 5 & 19 & Do. \\
\hline
\end{tabular}


Table 4. Ranked-mean constituent loads by storm type for Princeton, Massachusetts, 1983-85, and results from the Kruskal-Wallis test of differences among the ranked means

[Significant differences in ranked-mean values among storm types: Five-percent significance level used for the Kruskal-Wallis test. $\mu \mathrm{g} / \mathrm{m}^{2}$, microgram per square meter; $\mathrm{mg} / \mathrm{m}^{2}$, milligram per square meter. Do., ditto]

\begin{tabular}{|c|c|c|c|c|c|c|c|}
\hline \multirow{3}{*}{ Chemical constituent } & \multicolumn{6}{|c|}{ Storm type } & \multirow{3}{*}{$\begin{array}{l}\text { Significant differences in ranked-mean } \\
\text { values among storm types }\end{array}$} \\
\hline & \multicolumn{2}{|c|}{ Oceanic cyclone } & \multicolumn{2}{|c|}{ Continental cyclone } & \multicolumn{2}{|c|}{ Cold front } & \\
\hline & $\begin{array}{l}\text { Number } \\
\text { of storms }\end{array}$ & $\begin{array}{l}\text { Ranked } \\
\text { mean }\end{array}$ & $\begin{array}{l}\text { Number } \\
\text { of storms }\end{array}$ & $\begin{array}{l}\text { Ranked } \\
\text { mean }\end{array}$ & $\begin{array}{l}\text { Number } \\
\text { of storms }\end{array}$ & $\begin{array}{l}\text { Ranked } \\
\text { mean }\end{array}$ & \\
\hline Hydrogen ions $\left(\mu \mathrm{g} / \mathrm{m}^{2}\right)$ & 26 & 442 & 20 & 735 & 24 & 362 & Continental cyclones greater than cold-front storms. \\
\hline Calcium $\left(\mathrm{mg} / \mathrm{m}^{2}\right)$ & 17 & 1.09 & 18 & 1.22 & 9 & .99 & Not significant. \\
\hline Magnesium (mg/m²) & 17 & .38 & 18 & .39 & 9 & .18 & Do. \\
\hline Sodium $\left(\mathrm{mg} / \mathrm{m}^{2}\right)$ & 16 & 3.30 & 18 & 2.90 & 9 & 1.96 & Do. \\
\hline Potassium $\left(\mathrm{mg} / \mathrm{m}^{2}\right)$ & 17 & .46 & 18 & .48 & 9 & .34 & Do. \\
\hline Sulfate $\left(\mathrm{mg} / \mathrm{m}^{2}\right)$ & 17 & 19.6 & 18 & 25.8 & 9 & 17.2 & Do. \\
\hline Chloride $\left(\mathrm{mg} / \mathrm{m}^{2}\right)$ & 17 & 3.18 & 28 & 3.16 & 9 & 2.48 & Do. \\
\hline Fluoride $\left(\mathrm{mg} / \mathrm{m}^{2}\right)$ & 16 & .03 & 18 & .07 & 9 & .03 & Do. \\
\hline Bromide $\left(\mathrm{mg} / \mathrm{m}^{2}\right)$ & 4 & $\iota^{\prime} 0$ & 6 & .8 & 3 & ${ }^{1} 0$ & $\begin{array}{l}\text { Oceanic cyclones and cold-front storms less than } \\
\text { continental cyclones. }\end{array}$ \\
\hline Silica $\left(\mathrm{mg} / \mathrm{m}^{2}\right)$ & 10 & .03 & 13 & .07 & 7 & .12 & Not significant. \\
\hline Nitrate, as nitrogen $\left(\mathrm{mg} / \mathrm{m}^{2}\right)$ & 16 & 3.59 & 18 & 3.92 & 9 & 3.33 & Do. \\
\hline Ammonium, as nitrogen $\left(\mathrm{mg} / \mathrm{m}^{2}\right)$ & 16 & 1.5 & 18 & 1.69 & 9 & 1.31 & Do. \\
\hline Phosphorus, as phosphorus $\left(\mathrm{mg} / \mathrm{m}^{2}\right)$ & ) 15 & .06 & 13 & .01 & 6 & .01 & Do. \\
\hline Orthophosphate phosphorus, & & & & & & & \\
\hline as phosphorus (mg/m $\left.{ }^{2}\right)$ & 14 & .05 & 14 & .01 & 7 & .08 & Do. \\
\hline Aluminum $\left(\mu \mathrm{g} / \mathrm{m}^{2}\right)$ & 8 & 576 & 6 & 270 & 4 & 290 & Do. \\
\hline Barium $\left(\mu \mathrm{g} / \mathrm{m}^{2}\right)$ & 3 & 305 & 7 & 170 & 5 & 170 & Do. \\
\hline Copper $\left(\mu \mathrm{g} / \mathrm{m}^{2}\right)$ & 10 & 54 & 8 & 110 & 5 & 84 & Continental cyclones greater than oceanic cyclones. \\
\hline Iron $\left(\mu \mathrm{g} / \mathrm{m}^{2}\right)$ & 16 & 120 & 15 & 138 & 10 & 100 & Not significant. \\
\hline Lead $\left(\mu \mathrm{g} / \mathrm{m}^{2}\right)$ & 10 & 59 & 8 & 94 & 5 & 94 & Do. \\
\hline Manganese $\left(\mu \mathrm{g} / \mathrm{m}^{2}\right)$ & 16 & 18 & 15 & 16 & 10 & 15 & Do. \\
\hline Strontium $\left(\mu \mathrm{g} / \mathrm{m}^{2}\right)$ & 3 & 9.4 & 7 & 7.4 & 5 & 7.3 & Do. \\
\hline $\operatorname{Zinc}\left(\mu \mathrm{g} / \mathrm{m}^{2}\right)$ & 3 & 169 & 7 & 198 & 5 & 172 & Do. \\
\hline
\end{tabular}

${ }^{1}$ Loads were assumed to be zero for those constituents for which the ranked-mean concentrations were less than the detection limit for the laboratory analysis. 
As indicated in table 3, oceanic cyclones produced precipitation with significantly lower concentrations of sulfate (ranked mean, $1.01 \mathrm{mg} / \mathrm{L}$ ) than did cold-front storms (ranked mean, $1.50 \mathrm{mg} / \mathrm{L}$ ) and continental cyclones (ranked mean, $1.34 \mathrm{mg} / \mathrm{L}$ ). As with hydrogen ions, this difference reflects less exposure to the byproducts of fossil-fuel combustion for airmasses moving over the Atlantic Ocean prior to entering the oceanic cyclones in Massachusetts. As a consequence of these differences in sulfate and hydrogen-ion concentrations, the $\mathrm{pH}$ of precipitation, computed from the ranked-mean hydrogen-ion concentration, was 4.5 in oceanic cyclones, 4.4 in continental cyclones, and 4.2 in cold-front storms.

In precipitation from oceanic cyclones, the median sulfate concentration was nine times the chloride and sodium concentrations even though sulfate concentration in sea water is one-seventh the chloride concentration and one-fourth the sodium concentration. Because of the lack of similarity between these constituent-concentration ratios in precipitation and sea water, most of the sulfate in precipitation from oceanic cyclones probably is not derived from seawater spray and, therefore, not derived from rainout from warm, moist air that has passed over the ocean. Rather, the sulfate is attributed to washout from the underlying cool air of continental origin that has been exposed to fossil-fuel combustion, which Galloway and Whelpdale (1980) determined to be the main source of sulfate in the northeastern United States.

The differences among nitrate concentrations in precipitation samples from the three storm types were not statistically significant. This finding was unexpected because nitrate is derived from the by-products of fossil-fuel combustion, and its relation of concentration among storm types was expected to be about the same as for sulfate. Ranked-mean nitrate concentrations were $0.23 \mathrm{mg} / \mathrm{L}$ for precipitation samples from cold-front storms, $0.20 \mathrm{mg} / \mathrm{L}$ for precipitation samples from continental cyclones, and $0.15 \mathrm{mg} / \mathrm{L}$ for precipitation samples from oceanic cyclones (table 3 ). Although the pattern of these ranked-mean concentrations is similar to that for sulfate, the Kruskal-Wallis test indicated that the differences were not significant at the 5-percent level. A likely reason for the inconsistency in results for sulfate and nitrate at Princeton is that nitrate concentrations in precipitation are strongly affected by agricultural activity (Munger and Eisenreich, 1983). Annual loads at Quabbin Reservoir (discussed later) further demonstrate the effects of nitrate from agricultural activity on precipitation chemistry.

Precipitation from storms with large components of oceanic air did not contain substantial concentrations of constituents commonly detected in seawater, with the exception of sulfate. The ranked-mean concentrations in precipitation of the other common constituents in seawater (chloride, sodium, magnesium, calcium, and potassium) were less than $0.20 \mathrm{mg} / \mathrm{L}$ (table 3 ) irrespective of storm type; whereas the ranked-mean concentration of sulfate was $1.01 \mathrm{mg} / \mathrm{L}$ for oceanic cyclones. The statistical analysis indicated that, except for sulfate ions, no differences in ranked means of the common seawater constituents were significant at the 5-percent level among the three storm types. However, sodium and chloride concentrations were less than the detection limit of $0.2 \mathrm{mg} / \mathrm{L}$ (changed to one-half of the detection limit, $0.10 \mathrm{mg} / \mathrm{L}$, in the statistical analysis) in about 20 percent of the samples. Thus, it is uncertain whether a significant difference between storm types would have resulted if these samples had been analyzed to a lower detection limit. Examination of data in table 3 indicates this possibility for sodium but not for chloride.

Only 3 other constituents-aluminum, bromide, and copper - of the 23 constituents analyzed for were shown to be affected by storm type. The results for these constituents were mixed, because the statistically significant differences among storm types for aluminum, bromide, and copper could not be logically explained on the basis of the paths taken by the airmasses composing each storm type. For example, if these constituents were present mostly in a particular storm type having significant amounts of continental or oceanic air, then the differences in concentrations or loads among storm types could be explained on that basis alone. Copper was the only constituent with a tendency to be at higher concentrations in precipitation from storm types containing a large proportion of continental air. Even so, some inconsistencies in copper concentrations cannot be readily explained. For example, differences in copper concentrations in precipitation from oceanic cyclones and cold-front storms were not significant; differences in copper concentrations in precipitation from coldfront storms and continental cyclones were not significant; but copper concentrations in precipitation from continental cyclones were significantly higher than those in precipitation from oceanic cyclones. The 
copper in precipitation probably comes from the smelting of zinc ore in New Jersey. However, assuming that the atmospheric transport properties of lead, zinc, and copper are similar, lead and zinc concentrations should have shown tendencies similar to those for copper because all three metallic ions are present in ore used to smelt for any one of those three metals. Ranked-mean concentrations of copper, lead, and zinc in table 3 indicate that continental and cold-front storms contained higher concentrations of these ions even though differences in lead and zinc concentrations were not statistically significant among storm types.

The inconsistencies for aluminum and bromide were more unexpected than those for copper. Bromide has been identified as a compound used in gasoline (Wedberg and others, 1974), and coal combustion and soil dust have been identified as sources of aluminum (Paciga and Jervis, 1976). These sources are land based and could explain why precipitation from continental cyclones had significantly higher concentrations of bromide than that from oceanic cyclones. If the source is continental in origin, however, then precipitation from cold-front storms should have had bromide concentrations similar to that from continental cyclones because airmasses for both storm types are mainly continental in origin. Similarly, aluminum concentrations were relatively high in precipitation from cold-front storms (continental air), which was expected, but aluminum concentrations also were high in precipitation from oceanic cyclones (oceanic air), which was unexpected because of an absence of land-based sources. In addition, significantly lower concentrations of aluminum in precipitation from continental cyclones (mainly continental air but some oceanic air) were unexpected because of the proportion of continental air in these cyclones.

A possible reason for these differences in aluminum, bromide, and copper concentrations in precipitation among storm types could be that more mixing of continental and oceanic airmasses occurs within each of these storm types than had been expected. However, these differences, particularly for aluminum and bromide ions, are most likely artifacts of the small sample size or the large number of values less than the detection limit that were rounded, producing an abnormally skewed distribution. Seven aluminum concentrations were less than the detection limit in 20 precipitation samples, and 8 bromide concentrations were less than the detection limit in 13 precipitation samples.
Results of the statistical analysis indicated that the ranked-mean concentration in precipitation (by constituent and not among constituents) from all three storm types seems to be indistinguishable for ammonium, orthophosphate phosphorus, phosphorus, silica, barium, strontium, fluoride, iron, and manganese. No significant differences were found among ranked-mean concentrations of these constituents in precipitation as related to storm type; ranked-mean concentrations of these constituents were low (table 3 ), indicating that the sources of these constituents are relatively small and widely dispersed throughout the eastern United States.

The statistical analysis of ranked-mean constituent loads indicated similar relations among precipitation chemistry and storm type as for the statistical analysis of ranked-mean constituent concentrations. Only the ionic loads of hydrogen, bromide, and copper were significantly different by storm type (table 4). Significant differences also were found in the rankedmean concentrations of these three constituents. However, differences in loads in precipitation of two other constituents, sulfate and aluminum, whose rankedmean concentrations were significantly different among storm types, were not significant. Storm type did not significantly affect the quantity of material that reached land surface at Princeton in precipitation for calcium, magnesium, sodium, potassium, chloride, sulfate, fluoride, nitrate, ammonium, orthophosphate phosphorus, phosphorus, silica, aluminum, barium, iron, lead, manganese, strontium, and zinc.

At this inland site, one clear implication from the statistical analysis is that even though precipitation depth for both types of cyclonic storms is higher than for cold-front storms, precipitation depth does not significantly affect constituent loads at land surface, despite the relations among ranked means of various constituent concentrations and the three storm types. This is true for all constituents examined except for hydrogen, bromide, and copper ions.

\section{Truro Site}

Results from the statistical analysis indicate that depth and duration of precipitation at Truro were affected by storm type but that precipitation intensity was not affected by storm type (table 5 ). These differences in storm characteristics among storm types are consistent with the results for Princeton. 
Table 5. Ranked-mean precipitation characteristics and constituent concentrations by storm type for Truro, Massachusetts, 1983-85, and results from the Kruskal-Wallis test of differences among the ranked means

[Significant differences in ranked-mean values among storm types: Five-percent significance level used for the Kruskal-Wallis test. mm, millimeter; $h$, hour; $\mu \mathrm{S} / \mathrm{cm}$, microsiemen per centimeter; ${ }^{\circ} \mathrm{C}$, degrees Celsius; $\mu \mathrm{g} / \mathrm{L}$, microgram per liter; $\mathrm{mg} / \mathrm{L}$, milligram per liter. <, actual value is less than the detection limit for the constituent concentration. Do., ditto]

\begin{tabular}{|c|c|c|c|c|c|c|c|}
\hline \multirow{3}{*}{$\begin{array}{l}\text { Precipitation characteristic } \\
\text { or chemical constituent }\end{array}$} & \multicolumn{6}{|c|}{ Storm type } & \multirow{3}{*}{$\begin{array}{l}\text { Significant differences in ranked-mean } \\
\text { values among storm types }\end{array}$} \\
\hline & \multicolumn{2}{|c|}{ Oceanic cyclone } & \multicolumn{2}{|c|}{ Continental cyclone } & \multicolumn{2}{|c|}{ Cold front } & \\
\hline & $\begin{array}{l}\text { Jumber of } \\
\text { storms }\end{array}$ & $\begin{array}{c}\text { Ranked } \\
\text { mean }\end{array}$ & $\begin{array}{l}\text { Number } \\
\text { of storms }\end{array}$ & $\begin{array}{l}\text { Ranked } \\
\text { mean }\end{array}$ & $\begin{array}{l}\text { Number } \\
\text { of storms }\end{array}$ & $\begin{array}{c}\text { Ranked } \\
\text { mean }\end{array}$ & \\
\hline Precipitation quantity (mm) & 24 & 17.5 & 21 & 15.2 & 21 & 11.7 & Oceanic cyclones greater than cold-front storms. \\
\hline Precipitation duration (h) & 24 & 18 & 21 & 14 & 21 & 11 & $\begin{array}{l}\text { Oceanic cyclones greater than cold-front storms } \\
\text { and continental cyclones. }\end{array}$ \\
\hline Precipitation intensity $(\mathrm{mm} / \mathrm{h})$ & 24 & 1.04 & 21 & 1.27 & 21 & 1.14 & Not significant. \\
\hline \multicolumn{8}{|l|}{ Specific conductance } \\
\hline$\left(\mu \mathrm{S} / \mathrm{cm}\right.$ at $\left.25^{\circ} \mathrm{C}\right)$ & 24 & 32 & 21 & 34 & 21 & 27 & Do. \\
\hline $\mathrm{pH}$ (standard units) & 24 & 4.5 & 21 & 4.5 & 21 & 4.4 & Do. \\
\hline Hydrogen ions $(\mu \mathrm{g} / \mathrm{L})$ & 24 & 30.6 & 21 & 30 & 21 & 39.5 & Do. \\
\hline Calcium (mg/L) & 19 & .11 & 19 & .13 & 15 & .09 & Continental cyclones greater than cold-front storms. \\
\hline Magnesium (mg/L) & 19 & .16 & 19 & .21 & 15 & .08 & $\begin{array}{l}\text { Both cyclonic storm types greater than cold-front } \\
\text { storms. }\end{array}$ \\
\hline Sodium $(\mathrm{mg} / \mathrm{L})$ & 19 & 1.40 & 19 & 1.85 & 15 & .50 & Do. \\
\hline Potassium (mg/L) & 18 & .07 & 19 & .10 & 14 & .05 & Do. \\
\hline Sulfate $(\mathrm{mg} / \mathrm{L})$ & 19 & 1.82 & 19 & 1.91 & 15 & 1.38 & Not significant. \\
\hline Chloride (mg/L) & 19 & 2.32 & 19 & 3.30 & 15 & 1.08 & $\begin{array}{l}\text { Both cyclonic storm types greater than cold-front } \\
\text { storms. }\end{array}$ \\
\hline Fluoride (mg/L) & 19 & .01 & 19 & .01 & 19 & 0 & Not significant. \\
\hline Bromide (mg/L) & 5 & .03 & 6 & .01 & 4 & .01 & Do. \\
\hline Silica $(\mathrm{mg} / \mathrm{L})$ & 10 & 0 & 14 & 0 & 6 & 0 & Do. \\
\hline Nitrate, as nitrogen (mg/L) & 19 & .15 & 19 & .11 & 13 & .24 & Do. \\
\hline Ammonium, as nitrogen (mg/L) & 18 & .08 & 18 & .08 & 15 & .06 & Do. \\
\hline Phosphorus, as phosphorus (mg/L) & 14 & .001 & 12 & .001 & 11 & .001 & Do. \\
\hline \multicolumn{8}{|l|}{ Orthophosphate phosphorus, } \\
\hline as phosphorus (mg/L) & 13 & .001 & 12 & .001 & 11 & .001 & Do. \\
\hline Aluminum $(\mu \mathrm{g} / \mathrm{L})$ & 8 & 10 & 4 & 10 & 5 & 10 & Do. \\
\hline Barium $(\mu \mathrm{g} / \mathrm{L})$ & 3 & 13 & 7 & 12 & 3 & 10 & Do. \\
\hline Copper $(\mu \mathrm{g} / \mathrm{L})$ & 7 & 7.6 & 7 & 7.6 & 5 & 2.4 & Do. \\
\hline Iron $(\mu \mathrm{g} / \mathrm{L})$ & 17 & 5 & 16 & 4 & 12 & 4 & Do. \\
\hline Lead $(\mu \mathrm{g} / \mathrm{L})$ & 8 & 1.1 & 7 & 1.5 & 5 & 1 & Do. \\
\hline Manganese $(\mu \mathrm{g} / \mathrm{L})$ & 17 & .5 & 16 & .5 & 12 & .5 & Do. \\
\hline Strontium $(\mu \mathrm{g} / \mathrm{L})$ & 3 & .9 & 7 & 2.4 & 4 & 1.3 & Do. \\
\hline Zinc $(\mu \mathrm{g} / \mathrm{L})$ & 3 & 15 & 7. & 10 & 3 & 6 & Do. \\
\hline
\end{tabular}


Precipitation quality at Truro seems to be dominated by the proximity of the Atlantic Ocean to the east and north and of Cape Cod Bay to the west (fig. 1). The statistical analysis on concentration data (table 5) indicates that ranked-mean concentrations of chloride, sodium, magnesium, calcium, and potassium ions in precipitation differed significantly by storm type. Ranked-mean concentrations of these ions were equal for precipitation from both types of cyclones, whereas the ranked-mean concentrations for precipitation from cyclones, except that for calcium, were greater than the ranked-mean concentrations for precipitation from cold-front storms. Calcium ion in precipitation seemed to be affected differently by storm type, differences among storm types were still significant. Because these five constituents make up the major ions in seawater, these results were as expected given the proximity of the site to the ocean. In addition, cyclones are large well-organized systems in which surface-level winds blow counterclockwise about the center of low pressure. This characteristic wind pattern means that the winds blowing over the site will be coming off seawater regardless of where the low-pressure center passes. in relation to the site. The action of wind blowing across the tops of waves entrains tiny sea water droplets in the air.

Concentrations of sulfate ions in precipitation did not differ significantly by storm type. This result was unexpected because sulfate is the third most common ion in seawater. This similarity among storm types may have been caused by anthropogenic sources on land that are large enough (Galloway and Whelpdale, 1980) to raise the sulfate concentrations in precipitation from advancing cold fronts to approximately the same as ocean-derived concentrations.

The effect of the ocean on precipitation quality at Truro was even more obvious when load data were used in the statistical analysis (table 6): the six common constituents in seawater-chloride, sulfate, sodium, magnesium, calcium, and potassium-were all affected by storm type. Except for sulfate, these are the same constituents identified as being affected by storm type when the concentration data were analyzed. Mean loads in precipitation from both types of cyclones were equal, and, with the exception of calcium, precipitation from both types of cyclones deposited greater loads than precipitation from cold-front storms did. Calcium load, as was the case for calcium concentration, seemed to be affected slightly differently by storm type, but significant differences were still noted among storm types (table 6). Of the 22 constituents tested for differences in load in precipitation among storm types, hydrogen, fluoride, bromide, silica, nitrate, ammonium, phosphorus, orthophosphate phosphorus, aluminum, barium, copper, iron, lead, manganese, strontium, and zinc were not significantly affected. This finding indicates that these constituents are at about the same concentration in all airmasses that collide to form precipitation.

\section{DEPOSITION OF DISSOLVED CHEMICAL CONSTITUENTS}

One goal of this study was to determine the amounts of dissolved chemical constituents deposited in Massachusetts by precipitation during 1983-85. The following sections of the report describe various analyses of the precipitation-quality data set related to this goal. Specifically, these sections address (1) statistical distributions of storm and precipitation characteristics, (2) comparison of constituent concentrations in precipitation at Princeton and Truro, including discussion of oceanic and anthropogenic effects on those concentrations, (3) relation of constituent concentrations in precipitation to precipitation quantity, and (4) annual and seasonal constituent concentrations and loads in precipitation.

\section{Statistical Distributions of Storm and Precipitation-Quality Characteristics}

Statistical compilations of the storm characteristics and the chemical constituents in precipitation from storms at Princeton and Truro are listed in tables 7 and 8 , respectively. The base data from which these statistics were derived are listed in tables 21 and 22 . 
Table 6. Ranked-mean constituent loads by storm type for Truro, Massachusetts, 1983-85, and results from the Kruskal-Wallis test of differences among the ranked means

[Significant differences in ranked-mean values among storm types: Five-percent significance level used for the Kruskal-Wallis test. $\mu \mathrm{g} / \mathrm{m}^{2}$, microgram per square meter; $\mathrm{mg} / \mathrm{m}^{2}$, milligram per square meter. Do., ditto]

\begin{tabular}{|c|c|c|c|c|c|c|c|}
\hline \multirow{3}{*}{ Chemical constituent } & \multicolumn{6}{|c|}{ Storm type } & \multirow{3}{*}{$\begin{array}{l}\text { Significant differences in ranked-mean } \\
\text { values among storm types }\end{array}$} \\
\hline & \multicolumn{2}{|c|}{ Oceanic cyclone } & \multicolumn{2}{|c|}{ Continental cyclone } & \multicolumn{2}{|c|}{ Cold front } & \\
\hline & $\begin{array}{l}\text { Number of } \\
\text { storms }\end{array}$ & $\begin{array}{l}\text { Ranked } \\
\text { mean }\end{array}$ & $\begin{array}{c}\text { Number } \\
\text { of storms }\end{array}$ & $\begin{array}{l}\text { Ranked } \\
\text { mean }\end{array}$ & $\begin{array}{l}\text { Number } \\
\text { of storms }\end{array}$ & $\begin{array}{c}\text { Ranked } \\
\text { mean }\end{array}$ & \\
\hline Hydrogen ions $\left(\mu \mathrm{g} / \mathrm{m}^{2}\right)$ & 24 & 485 & 21 & 468 & 21 & 426 & Not significant. \\
\hline Calcium $\left(\mathrm{mg} / \mathrm{m}^{2}\right)$ & 19 & 2.31 & 19 & 2.53 & 15 & 1.36 & Continental cyclones greater than cold-front storms. \\
\hline Magnesium (mg/m²) & 19 & 3.13 & 19 & 5.46 & 15 & 1.21 & $\begin{array}{l}\text { Both cyclonic storm types greater than cold-front } \\
\text { storms. }\end{array}$ \\
\hline Sodium $\left(\mathrm{mg} / \mathrm{m}^{2}\right)$ & 19 & 31 & 19 & 42.4 & 15 & 10 & Do. \\
\hline Potassium $\left(\mathrm{mg} / \mathrm{m}^{2}\right)$ & 18 & 1.77 & 19 & 2.05 & 15 & .68 & Do. \\
\hline Sulfate $\left(\mathrm{mg} / \mathrm{m}^{2}\right)$ & 19 & 37 & 19 & 37.2 & 15 & 20.8 & Do. \\
\hline Chloride $\left(\mathrm{mg} / \mathrm{m}^{2}\right)$ & 19 & 47.9 & 19 & 67.2 & 15 & 18.3 & Do. \\
\hline Fluoride $\left(\mathrm{mg} / \mathrm{m}^{2}\right)$ & 19 & .05 & 19 & .05 & 19 & .04 & Not significant. \\
\hline Bromide $\left(\mathrm{mg} / \mathrm{m}^{2}\right)$ & 5 & .6 & 6 & .1 & 4 & .1 & Do. \\
\hline Silica $\left(\mathrm{mg} / \mathrm{m}^{2}\right)$ & 10 & .02 & 14 & .04 & 6 & .07 & Do. \\
\hline Nitrate, as nitrogen $\left(\mathrm{mg} / \mathrm{m}^{2}\right)$ & 19 & 3.40 & 19 & 2.40 & 13 & 3.25 & Do. \\
\hline Ammonium, as nitrogen $\left(\mathrm{mg} / \mathrm{m}^{2}\right)$ & 18 & 1.68 & 18 & 1.65 & 15 & .65 & Do. \\
\hline Phosphorus, as phosphorus ( $\mathrm{mg} / \mathrm{m}^{2}$ ) & 14 & .01 & 12 & .01 & 11 & .01 & Do. \\
\hline $\begin{array}{l}\text { Orthophosphate phosphorus, } \\
\left.\text { as phosphorus (mg/m } \mathrm{m}^{2}\right)\end{array}$ & 13 & .02 & 12 & .01 & 11 & .01 & Do. \\
\hline Aluminum $\left(\mu \mathrm{g} / \mathrm{m}^{2}\right)$ & 8 & 342 & 4 & 307 & 5 & $348^{\circ}$ & Do. \\
\hline Barium $\left(\mu \mathrm{g} / \mathrm{m}^{2}\right)$ & 3 & 235 & 7 & 237 & 3 & 124 & Do. \\
\hline Copper $\left(\mu \mathrm{g} / \mathrm{m}^{2}\right)$ & 7 & 60 & 7 & 56 & 5 & 59 & Do. \\
\hline Iron $\left(\mu \mathrm{g} / \mathrm{m}^{2}\right)$ & 17 & 117 & 16 & 76 & 12 & 71 & Do. \\
\hline Lead $\left(\mu \mathrm{g} / \mathrm{m}^{2}\right)$ & 8 & 54 & 7 & 57 & 5 & 48 & Do. \\
\hline Manganese $\left(\mu \mathrm{g} / \mathrm{m}^{2}\right)$ & 17 & 17 & 16 & 16 & 12 & 16 & Do. \\
\hline Strontium $\left(\mu \mathrm{g} / \mathrm{m}^{2}\right)$ & 3 & 16 & 7 & 49 & 4 & 26 & Do. \\
\hline Zinc $\left(\mu \mathrm{g} / \mathrm{m}^{2}\right)$ & 3 & 201 & 7 & 167 & 3 & 106 & Do. \\
\hline
\end{tabular}


Table 7. Statistics of precipitation characteristics and chemical constituents for storm data at Princeton, Massachusetts, $1983-85$

[mm, millimeter; $\mathrm{h}$, hour; $\mu \mathrm{S} / \mathrm{cm}$, microsiemen per centimeter; ${ }^{\circ} \mathrm{C}$, degree Celsius; $\mu \mathrm{g} / \mathrm{L}$, microgram per liter; mg/L, milligram per liter. <, actual value is less than the detection limit for the constituent concentration. --, not applicable]

\begin{tabular}{|c|c|c|c|c|c|c|c|c|c|c|c|c|}
\hline $\begin{array}{l}\text { Precipitation characteristic } \\
\text { or chemical constituent }\end{array}$ & $\begin{array}{c}\text { Number } \\
\text { of } \\
\text { samples }\end{array}$ & $\begin{array}{l}\text { Volume- } \\
\text { weighted } \\
\text { mean }\end{array}$ & $\begin{array}{l}\text { Arith- } \\
\text { metic } \\
\text { mean }\end{array}$ & $\begin{array}{l}\text { Mini- } \\
\text { mum }\end{array}$ & $\begin{array}{l}\text { Maxi- } \\
\text { mum }\end{array}$ & $\begin{array}{c}10 \text { th } \\
\text { per- } \\
\text { centile }\end{array}$ & $\begin{array}{c}25 \text { th } \\
\text { per- } \\
\text { centile }\end{array}$ & $\begin{array}{c}50 \text { th } \\
\text { per- } \\
\text { centile }\end{array}$ & $\begin{array}{c}\text { 75th } \\
\text { per- } \\
\text { centile }\end{array}$ & $\begin{array}{c}\text { 90th } \\
\text { per- } \\
\text { centile }\end{array}$ & $\begin{array}{c}\text { Detec- } \\
\text { tion } \\
\text { limit }\end{array}$ & $\begin{array}{l}\text { Number of } \\
\text { samples } \\
\text { less than } \\
\text { detection } \\
\text { limit }\end{array}$ \\
\hline Precipitation quantity (mm) & $\overline{83}$ & -- & 19.3 & 0.76 & 163 & 1.78 & 3.81 & 10.7 & 28.2 & 47.8 & -- & - \\
\hline Precipitation duration (h) & 83 & -- & 17.8 & 1 & 84 & 3 & 7 & 15 & 24 & 39.6 & -- & - \\
\hline Precipitation intensity $(\mathrm{mm} / \mathrm{h})$ & 83 & -- & 1.35 & .127 & 15.5 & .203 & .381 & .889 & 1.91 & 2.51 & - & -- \\
\hline $\begin{array}{l}\text { Specific conductance } \\
\left(\mu \mathrm{S} / \mathrm{cm} \text { at } 25^{\circ} \mathrm{C}\right)\end{array}$ & 83 & 16 & 30 & 3 & 130 & 7 & 13 & 24 & 36 & 61 & -- & - \\
\hline $\mathrm{pH}$ (standard units) & 83 & 4.46 & 4.21 & 3.5 & 5.2 & 3.9 & 4.1 & 4.3 & 4.6 & 4.9 & -- & -- \\
\hline Hydrogen ions $(\mu \mathrm{g} / \mathrm{L})$ & 83 & 34.7 & 62.6 & 6.4 & 320 & 13 & 25 & 51 & 80 & 130 & -- & -- \\
\hline Calcium $(\mathrm{mg} / \mathrm{L})$ & 48 & .07 & .09 & $<.02$ & .51 & .03 & .04 & .07 & .11 & .14 & $<0.02$ & 1 \\
\hline Magnesium (mg/L) & 48 & .04 & .04 & $<.01$ & .12 & $<.01$ & .01 & .03 & .06 & .08 & $<.01$ & 11 \\
\hline Sodium (mg/L) & 47 & .2 & .2 & .08 & 1.00 & $<.2$ & $<.2$ & $<.2$ & .3 & .5 & $<.2$ & 17 \\
\hline Potassium (mg/L) & 48 & .03 & .04 & $<.01$ & .18 & .01 & .01 & .03 & .05 & .09 & $<.01$ & 2 \\
\hline Sulfate $(\mathrm{mg} / \mathrm{L})$ & 48 & 1.18 & 1.66 & .20 & 11.50 & .42 & .75 & 1.22 & 1.88 & 3.42 & -- & - \\
\hline Chloride (mg/L) & 48 & .68 & .45 & $<.01$ & 6.31 & $<.20$ & $<.20$ & .20 & .33 & 1.03 & $\begin{array}{l}<.01 \\
<.20\end{array}$ & $\begin{array}{r}1 \\
15\end{array}$ \\
\hline Fluoride $(\mathrm{mg} / \mathrm{L})$ & 48 & .03 & .03 & $<.01$ & .64 & $<.01$ & $<.01$ & $<.01$ & .02 & .04 & $<.01$ & 30 \\
\hline Bromide $(\mathrm{mg} / \mathrm{L})$ & 14 & .02 & .03 & $<.01$ & .20 & $<.01$ & $<.01$ & $<.01$ & .03 & .15 & $<.01$ & 9 \\
\hline Silica $(\mathrm{mg} / \mathrm{L})$ & 33 & .01 & .01 & $<.01$ & .05 & $<.01$ & $<.01$ & $<.01$ & .01 & .04 & $<.01$ & 24 \\
\hline Nitrate, as nitrogen $(\mathrm{mg} / \mathrm{L})$ & 47 & .17 & .27 & $<.05$ & 1.30 & .07 & .10 & .18 & .32 & .64 & $<.05$ & 2 \\
\hline Ammonium, as nitrogen (mg/L) & 47 & .11 & .16 & $<.001$ & 1.20 & .01 & .03 & .09 & .20 & .39 & $\begin{array}{l}<.001 \\
<.01\end{array}$ & $\begin{array}{l}1 \\
2\end{array}$ \\
\hline $\begin{array}{l}\text { Phosphorus, as phosphorus } \\
\text { (mg/L) }\end{array}$ & 37 & .012 & .013 & $<.001$ & .184 & $<.001$ & $<.001$ & .001 & .006 & .021 & $<.001$ & 17 \\
\hline $\begin{array}{l}\text { Orthophosphate phosphorus, as } \\
\text { phosphorus (mg/L) }\end{array}$ & 38 & .004 & .004 & $<.001$ & .024 & $<.001$ & $<.001$ & .001 & .005 & .015 & $<.001$ & 19 \\
\hline Aluminum $(\mu \mathrm{g} / \mathrm{L})$ & 20 & 10 & 10 & $<10$ & 70 & $<10$ & $<10$ & 10 & 20 & 29 & $<10$ & 8 \\
\hline Barium $(\mu \mathrm{g} / \mathrm{L})$ & 15 & 14 & 12 & 4 & 26 & 5 & 9 & 12 & 14 & 20 & -- & -- \\
\hline Copper $(\mu \mathrm{g} / \mathrm{L})$ & 26 & 8.5 & 4.4 & $<.1$ & 40 & $<.2$ & .9 & 2.2 & 4.4 & 9.6 & $\begin{array}{l}<.1 \\
<.1 \\
<.5\end{array}$ & $\begin{array}{l}1 \\
2 \\
1\end{array}$ \\
\hline Iron $(\mu \mathrm{g} / \mathrm{L})$ & 45 & 8 & 10 & $<3$ & 130 & $<3$ & 3 & 5 & 8 & 14 & $<3$ & 8 \\
\hline Lead $(\mu \mathrm{g} / \mathrm{L})$ & 26 & 2.5 & 3 & .6 & 10 & .7 & 1.4 & 2.5 & 3.9 & 7.2 & $<2$ & 1 \\
\hline Manganese $(\mu \mathrm{g} / \mathrm{L})$ & 45 & 1 & 1 & $<1$ & 7 & $<1$ & $<1$ & $<1$ & 1 & 2 & $<1$ & 30 \\
\hline Strontium $(\mu \mathrm{g} / \mathrm{L})$ & $\begin{array}{l}15 \\
15\end{array}$ & $15^{.6}$ & $19^{.6}$ & $<3$ & $\begin{array}{r}1 \\
110\end{array}$ & $\begin{array}{l}<.5 \\
3\end{array}$ & $\begin{array}{l}<.5 \\
6\end{array}$ & $13^{.5}$ & $22^{.8}$ & $\begin{array}{r}1 \\
58\end{array}$ & $<.5$ & 5 \\
\hline Zinc $(\mu \mathrm{g} / \mathrm{L})$ & 10 & 15 & 17 & $<3$ & 110 & & 0 & 13 & 22 & 58 & $<3$ & 1 \\
\hline
\end{tabular}


Table 8. Statistics of precipitation characteristics and chemical constituents for storm data at Truro, Massachusetts, 1983-85

[mm, millimeter; h, hour; $\mu \mathrm{S} / \mathrm{cm}$, microsiemen per centimeter; ${ }^{\circ} \mathrm{C}$, degree Celsius; $\mu \mathrm{g} / \mathrm{L}$, microgram per liter; $\mathrm{mg} / \mathrm{L}$, milligram per liter, $<$, actual value is less than the detection limit for the constituent concentration. --, not applicable]

\begin{tabular}{|c|c|c|c|c|c|c|c|c|c|c|c|c|}
\hline $\begin{array}{l}\text { Precipitation characteristic } \\
\text { or chemical constituent }\end{array}$ & $\begin{array}{c}\text { Number } \\
\text { of } \\
\text { samples }\end{array}$ & $\begin{array}{l}\text { Volume- } \\
\text { weighted } \\
\text { mean }\end{array}$ & $\begin{array}{l}\text { Arith- } \\
\text { metic } \\
\text { mean }\end{array}$ & $\begin{array}{l}\text { Mini- } \\
\text { mum }\end{array}$ & $\begin{array}{l}\text { Maxi- } \\
\text { mum }\end{array}$ & $\begin{array}{c}\text { 10th } \\
\text { per- } \\
\text { centile }\end{array}$ & $\begin{array}{c}\text { 25th } \\
\text { per- } \\
\text { centile }\end{array}$ & $\begin{array}{c}\text { 50th } \\
\text { per- } \\
\text { centile }\end{array}$ & $\begin{array}{c}\text { 75th } \\
\text { per- } \\
\text { centile }\end{array}$ & $\begin{array}{c}\text { 90th } \\
\text { per- } \\
\text { centile }\end{array}$ & $\begin{array}{c}\text { Detec- } \\
\text { tion } \\
\text { limit }\end{array}$ & $\begin{array}{l}\text { Number of } \\
\text { samples } \\
\text { less than } \\
\text { detection } \\
\text { limit }\end{array}$ \\
\hline Precipitation quantity (mm) & 73 & -- & 20.8 & 0.76 & 94.7 & 3.81 & 7.62 & 14.5 & 23.4 & 59.9 & - & - \\
\hline Precipitation duration (h) & 73 & - & 18 & 1 & 82 & 4.4 & 8 & 14 & 23 & 37.6 & - & - \\
\hline Precipitation intensity $(\mathrm{mm} / \mathrm{h})$ & 73 & -. & 1.55 & .152 & 12.2 & .356 & .508 & 1.09 & 2.13 & 3.43 & -- & -- \\
\hline $\begin{array}{l}\text { Specific conductance } \\
\left(\mu \mathrm{S} / \mathrm{cm} \text { at } 25^{\circ} \mathrm{C}\right)\end{array}$ & 73 & 34 & 35 & 2 & 195 & 10 & 20 & 31 & 41 & 62 & - & - \\
\hline $\mathrm{pH}$ (standard units) & 73 & 4.54 & 4.34 & 3.6 & 5.4 & 4 & 4.2 & 4.4 & 4.8 & 5.1 & -- & -- \\
\hline Hydrogen ions $(\mu \mathrm{g} / \mathrm{L})$ & 73 & 29.0 & 46.4 & 4.0 & 250 & 9 & 16 & 40 & 64 & 92 & - & -- \\
\hline Calcium (mg/L) & 56 & .18 & .15 & .03 & 1.20 & .05 & .07 & .11 & .19 & $.29^{\circ}$ & -- & - \\
\hline Magnesium (mg/L) & 56 & .41 & .29 & $<.01$ & 3.40 & .03 & .07 & .14 & .31 & .69 & $<0.01$ & 2 \\
\hline Sodium (mg/L) & 55 & 3.3 & 2.4 & .05 & 28.0 & .29 & .5 & 1.2 & 3.1 & 5.6 & $<.2$ & 1 \\
\hline Potassium (mg/L) & 54 & .14 & .12 & $<.01$ & 1.10 & .03 & .05 & .06 & .15 & .26 & $<.01$ & 1 \\
\hline Sulfate (mg/L) & 56 & 1.92 & 2.05 & .21 & 8.41 & .48 & .99 & 1.86 & 2.54 & 3.35 & - & - \\
\hline Chloride $(\mathrm{mg} / \mathrm{L})$ & 56 & 6.26 & 4.43 & $<.20$ & 52.3 & .45 & .96 & 2.04 & 5.09 & 11.2 & $<.20$ & 2 \\
\hline Fluoride (mg/L) & 54 & .02 & .02 & $<.01$ & .67 & $<.01$ & $<.01$ & $<.01$ & .02 & .03 & $<.01$ & 35 \\
\hline Bromide (mg/L) & 16 & .05 & .03 & $<.01$ & .18 & $<.01$ & $<.01$ & .02 & .04 & .14 & $<.01$ & 7 \\
\hline Silica $(\mathrm{mg} / \mathrm{L})$ & 30 & $<.01$ & $<.01$ & $<.01$ & .03 & $<.01$ & $<.01$ & $<.01$ & $<.01$ & .02 & $<.01$ & 24 \\
\hline Nitrate, as nitrogen $(\mathrm{mg} / \mathrm{L})$ & 54 & .16 & .24 & $<.01$ & 1.06 & .02 & .07 & .16 & .32 & .48 & $\begin{array}{l}<.01 \\
<.05\end{array}$ & $\begin{array}{l}1 \\
4\end{array}$ \\
\hline Ammonium, as nitrogen $(\mathrm{mg} / \mathrm{L})$ & 54 & .10 & .13 & $<.001$ & 1.00 & $<.01$ & .03 & .07 & .17 & .30 & $\begin{array}{l}<.001 \\
<.01\end{array}$ & $\begin{array}{l}2 \\
6\end{array}$ \\
\hline $\begin{array}{l}\text { Phosphorus, as phosphorus } \\
\text { (mg/L) }\end{array}$ & 39 & .007 & .008 & $<.001$ & .095 & $<.001$ & $<.001$ & $<.001$ & .00 & .015 & $<.001$ & 22 \\
\hline $\begin{array}{c}\text { Orthophosphate phosphorus, as } \\
\text { phosphorus (mg/L) }\end{array}$ & 38 & .003 & .004 & $<.001$ & .054 & $<.001$ & $<.001$ & $<.001$ & .02 & 012 & $<.001$ & 22 \\
\hline Aluminum $(\mu \mathrm{g} / \mathrm{L})$ & 17 & 10 & 10 & $<10$ & 30 & $<10$ & $<10$ & 10 & 20 & 22 & $<10$ & 7 \\
\hline Barium $(\mu \mathrm{g} / \mathrm{L})$ & 13 & 11 & 11 & $<2$ & 24 & 2 & 10 & 12 & 13 & 20 & $<2$ & 1 \\
\hline Copper $(\mu \mathrm{g} / \mathrm{L})$ & 21 & 1.7 & 2.1 & .2 & 5.7 & .6 & 1 & 1.9 & 2.7 & 4.3 & -- & - \\
\hline Iron $(\mu \mathrm{g} / \mathrm{L})$ & 47 & 8 & 7 & $<3$ & 69 & $<3$ & $<3$ & 4 & 6 & 14 & $<3$ & 16 \\
\hline Lead $(\mu \mathrm{g} / \mathrm{L})$ & 22 & 1.7 & 2.1 & .2 & 6 & .2 & .7 & 1.4 & 4 & 5.6 & -- & -- \\
\hline Manganese $(\mu \mathrm{g} / \mathrm{L})$ & 47 & 1 & 1 & $<1$ & 4 & $<1$ & $<1$ & $<1$ & 1 & 2 & $<1$ & 31 \\
\hline Strontium $(\mu \mathrm{g} / \mathrm{L})$ & 14 & 2.3 & 2.7 & .7 & 10 & .7 & .8 & 1.5 & 4.2 & 7.5 & -- & - \\
\hline $\operatorname{Zinc}(\mu \mathrm{g} / \mathrm{L})$ & 13 & 10 & 13 & $<3$ & 40 & $<3$ & 3 & 12 & 19 & 35 & $<3$ & 3 \\
\hline
\end{tabular}


Summary statistics on physical properties and chemical constituents in tables 7 and 8 are representative (valid) for three ranges of precipitation depth, as follows:

\begin{tabular}{lc}
\hline Chemical classification & $\begin{array}{c}\text { Representative of } \\
\text { precipitation depth, } \\
\text { in millimeters, } \\
\text { greater than }\end{array}$ \\
\hline $\mathrm{pH}$ and specific conductance & 1.3 \\
$\begin{array}{l}\text { Common constituents (table 1), } \\
\text { iron, and manganese }\end{array}$ & 5.1 \\
Trace elements (table 2) & 12.7 \\
\hline
\end{tabular}

The summary statistics listed in tables 7 and 8 are volume-weighted mean; arithmetic mean; minimum; maximum; 10th, 25th, 50th (median), 75th, and 90th percentiles; number of samples less than the detection limit; and number of samples from which the statistics were computed. The 25 th and 75 th percentiles are useful because the range between those percentiles includes 50 percent of the sample concentrations. The 10th and 90th percentiles are listed to indicate how extreme the minimum and maximum concentrations and other measures are with regard to the rest of the data. For example, the maximum concentration detected for chloride in precipitation at Truro was $52.3 \mathrm{mg} / \mathrm{L}$, the next highest concentration was $20.1 \mathrm{mg} / \mathrm{L}$, and the 90 th-percentile concentration was $11.2 \mathrm{mg} / \mathrm{L}$.

In general, large ranges were found between minimum and maximum concentrations of many constituents at both sites. Many constituents were barely detectable in samples from some storms but were at high concentrations in samples from other storms. For example, chloride concentration in precipitation at Truro ranged from less than 0.20 to $52.3 \mathrm{mg} / \mathrm{L}$. For other constituents, such as fluoride (from less than 0.01 to $0.67 \mathrm{mg} / \mathrm{L}$ ), the range in concentration in precipitation was not as large as for chloride but was still relatively large. For some constituents, concentrations less than the detection limit were rarely found, but for others such as fluoride, silica, iron, manganese, and both phosphorus species, concentrations were less than the detection limit in many samples.
The range in concentrations between the 25th and 75th percentiles or the 10th and 90th percentiles may be applied to define the variability of a chemical-constituent pulse to the atmosphere, and concentrations at various percentiles may be applied to define the closeness or the intensity of the chemical sources. At Princeton, for example, the range of magnesium concentrations in precipitation $(<0.01$ to $0.12 \mathrm{mg} / \mathrm{L}$ ), the difference between the 10th and 90th percentiles $(<0.01$ to $0.08 \mathrm{mg} / \mathrm{L})$ and the difference between the 25 th and 75 th percentiles $(0.01$ to $0.06 \mathrm{mg} / \mathrm{L})$ all are fairly small, and concentrations generally are low. This distribution indicates that if the sources of magnesium in precipitation are local, the sources are small and constant; whereas if the sources of magnesium in precipitation are regional, they are large and relatively constant. These low concentrations in precipitation also may represent residual or background concentrations in the atmosphere at all times.

The arithmetic means of the various constituent concentrations generally are higher than the respective 50 th percentiles (medians) - by a factor of 2 for some constituents-indicating that the concentration data for nearly all constituents are skewed below the mean. The volume-weighted mean concentration of specific constituents can differ considerably from the arithmetic mean for the same constituent. This difference can be as much as plus or minus 50 percent of the volumeweighted mean concentration. As discussed earlier, this difference is related to the method used to calculate each type of mean. Both sets of means were included to show the difference between the volume-weighted mean used to obtain a composite concentration from precipitation samples (based on the product of constituent concentration and precipitation quantity in each storm), and the arithmetic mean used to obtain a measure of the central tendency of the concentrations without regard to the respective precipitation. At Princeton, for example, the volume-weighted mean concentration for sulfate in precipitation is $1.18 \mathrm{mg} / \mathrm{L}$ and the arithmetic mean concentration is $1.66 \mathrm{mg} / \mathrm{L}$. Statistical summaries for both sites indicate that the volume-weighted means for some constituents are higher than the respective arithmetic means. For other constituents, the relation is reversed. No distinct pattern is evident between constituents or sites.

Scarce trace-element concentrations in precipitation are listed in tables 9 and 10. Data for the common trace elements (aluminum, barium, bromide, copper, iron, lead, manganese, strontium, and zinc) listed in 
Table 9. Total number of samples, concentration range, and number of samples less than the detection limit for scarce trace elements in precipitation at Princeton, Massachusetts, 1983-85

$[\mu \mathrm{g} / \mathrm{L}$, microgram per liter; $<$, actual value is less than the detection limit for the constituent concentration]

\begin{tabular}{lccc}
\hline $\begin{array}{c}\text { Chemical } \\
\text { constituent }\end{array}$ & $\begin{array}{c}\text { Number } \\
\text { of } \\
\text { samples }\end{array}$ & $\begin{array}{c}\text { Number of } \\
\text { samples } \\
\text { less than } \\
\text { detection } \\
\text { limit }\end{array}$ & $\begin{array}{c}\text { Concentration } \\
\text { range } \\
(\mu \mathrm{g} / \mathrm{L})\end{array}$ \\
\hline Antimony & 5 & 5 & $<1$ to $<1$ \\
Arsenic & 23 & 19 & $<1$ to 1 \\
Beryllium & 14 & 11 & $<0.5$ to 0.7 \\
Boron & 12 & 10 & $<20$ to 30 \\
Cadmium & 15 & 11 & $<1$ to 2 \\
Chromium & 1 & 1 & $<3$ to 3 \\
Cobalt & 15 & 14 & $<4$ to 9 \\
Lithium & 15 & 13 & $<10$ to 10 \\
Molybdenum & 15 & 14 & $<1$ to 1 \\
Nickel & 2 & 1 & $<1$ to 2 \\
Selenium & 19 & 18 & $<1$ to 2 \\
Vanadium 1 & 22 & 10 & $<6$ to 6 \\
Vanadium & 4 & 3 & \\
\hline
\end{tabular}

${ }^{1}$ There were two different detection limits for vanadium.

Table 10. Total number of samples, concentration range, and number of samples less than the detection limit for scarce trace elements in precipitation at Truro, Massachusetts, 1983-85

$[\mu \mathrm{g} / \mathrm{L}$, microgram per liter; $<$, actual value is less than the detection limit for the constituent concentration]

\begin{tabular}{lccr} 
Chemical & $\begin{array}{c}\text { Number } \\
\text { of } \\
\text { constituent }\end{array}$ & $\begin{array}{c}\text { Number of } \\
\text { samples } \\
\text { less than } \\
\text { detection } \\
\text { limit }\end{array}$ & $\begin{array}{c}\text { Concentration } \\
\text { range } \\
(\mu \mathrm{g} / \mathrm{L})\end{array}$ \\
\hline Antimony & 3 & 3 & $<1$ \\
Arsenic & 21 & 15 & $<1$ to 1 \\
Beryllium & 10 & 10 & $<0.5$ \\
Boron & 14 & 13 & $<20$ to 20 \\
Cadmium & 13 & 11 & $<1$ to 3 \\
Chromium & 1 & 1 & $<1$ \\
Cobalt & 13 & 13 & $<3$ to $<3$ \\
Lithium & 13 & 12 & $<4$ to 6 \\
Molybdenum & 13 & 13 & $<10$ \\
Nickel & 2 & 1 & $<1$ to 1 \\
Selenium & 14 & 14 & $<1$ \\
Vanadium & 24 & 11 & $<6$ \\
Vanadium & 5 & 5 & to 2 \\
\hline
\end{tabular}

${ }^{1}$ There were two different detection limits for vanadium. tables 7 and 8 do not include many concentrations less than the detection limit; whereas more than one-half of the concentrations listed for each scarce trace element are less than the detection limit, and only a few concentrations are greater than the detection limit (tables 9 and 10). Trace elements detected regularly in precipitation at both sites were aluminum, barium, copper, iron, lead, strontium, and zinc when sufficient sample water was available for the most extensive chemical analysis. Other trace elements such as bromide, fluoride, manganese, and silica were detected less frequently in precipitation; but when detected, they were present at relatively high concentration with respect to the detection limit.

\section{Comparison of Constituent Concentrations at Princeton and Truro}

Volume-weighted mean concentrations in tables 7 and 8 indicate that at both sites most constituents in precipitation are present in low concentrations except for sulfate, sodium, chloride, hydrogen ions, and magnesium. Concentrations of sulfate, sodium, chloride, and magnesium are higher in precipitation at Truro, the coastal site, than in precipitation at Princeton, the inland site, indicating oceanic effects. In precipitation at Princeton, for instance, sulfate concentrations are highest among all constituents, and chloride concentrations are the next highest; whereas in precipitation at Truro, chloride concentrations are the highest, and sodium concentrations are the next highest. However, in terms of equivalent weight (chemically equivalent combining weight) shown in figure 6 (developed from tables 7 and 8 ), this order is slightly different. In precipitation at Princeton, hydrogen-ion equivalent weight is highest, at 29 percent, followed by chloride and sulfate at 21 and 16 percent, respectively; whereas in precipitation at Truro, chloride equivalent weight is highest, at 39 percent, followed by sodium and sulfate at 32 and 9 percent, respectively. These percentages are based on comparisons with the sum of the dissolved constituents-ammonium, calcium, hydrogen ion, magnesium, potassium, and sodium for cations and chloride, fluoride, nitrate, and sulfate for anions-that constitute most of the constituents in precipitation. Other constituents found at lesser amounts in precipitation at Princeton were nitrate at 11 percent, sodium at 9 percent, ammonium at 6 percent, calcium and magnesium at 3 percent each, potassium at 2 percent, and fluoride at 1 percent. In contrast, other constituents present at 


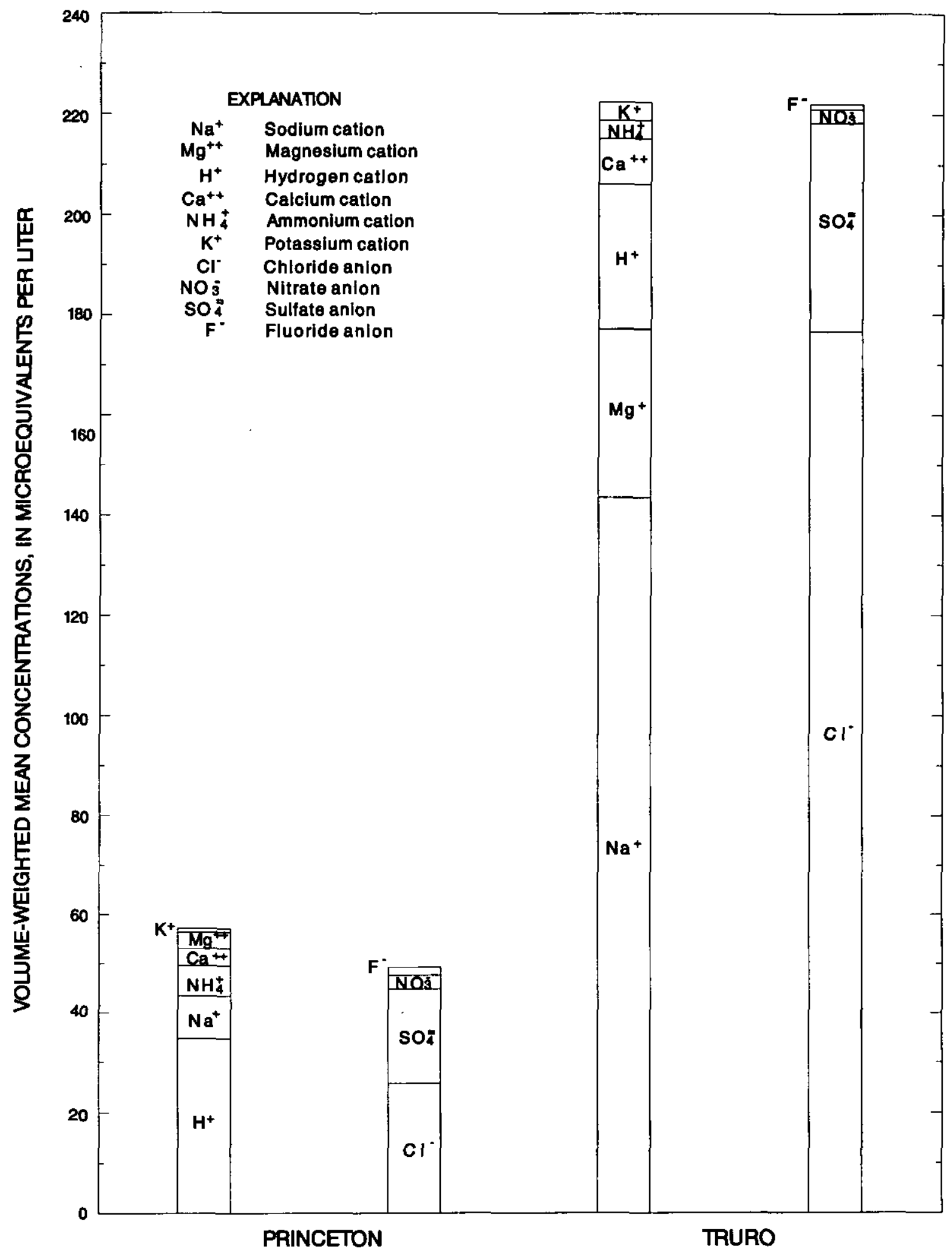

Figure 6. Concentrations of major dissolved constituents in storm-precipitation samples, Princeton and Truro, Massachusetts, 1983-85. 
lower levels in precipitation at Truro were magnesium at 7 percent, hydrogen ion at 6 percent, nitrate at 3 percent, calcium and ammonium at 2 percent each, potassium at 1 percent, and fluoride at less than 1 percent. At Princeton, six constituents-hydrogen ion, sulfate, chloride, nitrate, sodium, and ammonium-constitute 91 percent of the common dissolved constituents in precipitation; whereas at Truro, five constituentschloride, sodium, sulfate, magnesium, and hydrogen ion-constitute 93 percent of the common dissolved constituents in precipitation. In summary, the ionic composition of precipitation at these sites can be characterized as mostly hydrogen sulfate ( 50 percent of the constituents) at Princeton, reflecting the proximity to anthropogenic sources of sulfur compounds, and as mostly sodium chloride ( 71 percent of the constituents) at Truro, reflecting the proximity to a large natural source of salt (Atlantic Ocean).

The total amounts of the constituents in precipitation at the sites were compared by use of the sum of the cations and anions on a volume-weighted mean basis and a microequivalent basis. The sums of the volumeweighted means for the 10 major cations and anions were $2.6 \mathrm{mg} / \mathrm{L}$ at Princeton and $12.6 \mathrm{mg} / \mathrm{L}$ at Truro; thus, precipitation at Truro contains far more dissolved constituents than does precipitation at Princeton, because of the proximity of Truro to the Atlantic Ocean. On a microequivalent basis, the sums of the constituents at Princeton and Truro are 106 and $446 \mu \mathrm{eq} / \mathrm{L}$, respectively, indicating that the overall precipitation at Truro is four times more concentrated than precipitation at Princeton. This indicates inland precipitation is fairly dilute when compared to coastal precipitation; either the $176 \mu \mathrm{eq} / \mathrm{L}$ of chloride or the $144 \mu \mathrm{eq} / \mathrm{L}$ of sodium in precipitation at Truro was greater than the sum of all the cation and anion microequivalents in precipitation at Princeton. Comparison of the microequivalents of each constituent in precipitation at Princeton with those at Truro (fig. 6) or of the volume-weighted means (tables 7 and 8) demonstrates that certain constituents are more abundant in precipitation at Truro than in precipitation at Princeton. At Truro, for example, precipitation contains 14 times more sodium, 10 times more magnesium, 9 times more chloride, 2.5 times more calcium, and 1.6 times more sulfate on the average than does precipitation at Princeton. In contrast, volume-weighted mean concentrations of certain constituents in precipitation-including hydrogen ion, fluoride, silica, ammonium, nitrate, orthophosphate phosphorus, and phosphorus-differ by $0.010 \mathrm{mg} / \mathrm{L}$ or less between sites.

At both sites, volume-weighted mean concentrations of aluminum, bromide, fluoride, iron, and manganese in precipitation are virtually equal. This equality in volume-weighted mean concentrations in precipitation at both sites indicates that the sources of all these materials must be the same and either very small or at a considerable distance from both sites. Other trace elements such as barium, copper, lead, and zinc are at higher volume-weighted mean concentrations in precipitation at Princeton than in precipitation at Truro, indicating either that the source of these materials is closer to Princeton than to Truro or that both sites are not affected by the same parcels of air. The volume-weighted mean concentration of strontium in precipitation at Truro is higher than at Princeton, possibly because of the proximity of Truro to coal-fired electrical generating stations.

\section{Oceanic Effects}

Seawater would be expected to significantly affect the precipitation quality in Massachusetts because the State has about $2,400 \mathrm{~km}$ of Atlantic Ocean coastline. Many reports detail the dominant effects of the ocean on precipitation quality in coastal areas (for example, Granat, 1972, and Hendry and others, 1984), effects that are due primarily to the high concentrations of certain elements and compounds in seawater. The average concentrations of the common constituents in seawater are chloride $(19,000 \mathrm{mg} / \mathrm{L})$, sodium $(10,500 \mathrm{mg} / \mathrm{L})$, sulfate $(2,700 \mathrm{mg} / \mathrm{L})$, magnesium $(1,350 \mathrm{mg} / \mathrm{L})$, calcium $(410 \mathrm{mg} / \mathrm{L})$, and potassium $(390 \mathrm{mg} / \mathrm{L})(\mathrm{Hem}$, 1985, p. 7).

The seawater-ratio analysis in table 11 indicates that the composition of precipitation falling at Truro is, on the average, dilute seawater (oceanic origin), except that sulfate is considerably enriched over the likely concentration from oceanic origin alone. Except for sulfate, oceanic origin accounts for from 72 to 97 percent of the concentrations in precipitation at Truro (table 11). 
Table 11. Volume-weighted mean seawater concentrations in precipitation at Princeton and Truro, Massachusetts, 1983-85

[--, not applicable; $\mathrm{mg} / \mathrm{L}$, milligram per liter]

\begin{tabular}{|c|c|c|c|c|c|}
\hline $\begin{array}{l}\text { Chemical } \\
\text { constituent }\end{array}$ & $\begin{array}{l}\text { Constituent } \\
\text { concentration in } \\
\text { precipitation } \\
(\mathrm{mg} / \mathrm{L})\end{array}$ & $\begin{array}{c}\text { Seawater } \\
\text { concentration in } \\
\text { precipitation from } \\
\text { chloride-based ratio } \\
(\mathrm{mg} / \mathrm{L})\end{array}$ & $\begin{array}{c}\text { Seawater } \\
\text { concentration } \\
\text { in precipitation } \\
\text { from sodium- } \\
\text { based ratio } \\
(\mathrm{mg} / \mathrm{L}) \\
\end{array}$ & $\begin{array}{l}\text { Mean seawater } \\
\text { concentration in } \\
\text { precipitation } \\
(\mathrm{mg} / \mathrm{L})\end{array}$ & $\begin{array}{c}\text { Seawater } \\
\text { component of } \\
\text { precipitation } \\
\text { (percent) }\end{array}$ \\
\hline \multicolumn{6}{|c|}{ PRINCETON } \\
\hline Chloride & 0.68 & -- & 0.21 & 0.21 & 31 \\
\hline Sodium & .20 & 0.13 & -- & .13 & 67 \\
\hline Sulfate & 1.18 & .09 & .05 & .07 & 6 \\
\hline Magnesium & .04 & .02 & .02 & .02 & 50 \\
\hline Calcium & .070 & .010 & .008 & .010 & 14 \\
\hline Potassium & .030 & .006 & .007 & .006 & 20 \\
\hline \multicolumn{6}{|c|}{ TRURO } \\
\hline Chloride & 6.26 & -- & 5.79 & 5.79 & 92 \\
\hline Sodium & 3.3 & 3.2 & -- & 3.2 & 97 \\
\hline Sulfate & 1.92 & .89 & .86 & .88 & 46 \\
\hline Magnesium & .41 & .38 & .40 & .39 & 95 \\
\hline Calcium & .18 & .13 & .13 & .13 & 72 \\
\hline Potassium & .14 & .12 & .12 & .12 & 86 \\
\hline
\end{tabular}

Analysis of the percentage of constituent concentration attributable to seawater produced definite results at Truro but mixed results at Princeton (table 11). In precipitation at Princeton, sodium appears to be largely of oceanic origin, but oceanic contributions of calcium, chloride, magnesium, potassium, and sulfate concentrations are low enough to be significantly enriched to varying degrees by non-oceanic sources that could be either natural or anthropogenic. Even though the absolute concentrations of these six constituents in precipitation at Princeton are low compared to those at Truro, precipitation at Princeton still contains a fairly high percentage of solutes of oceanic origin (table 11).

Possible non-oceanic sources for these six constituents in precipitation at Princeton are as follows. Additional chloride comes from anthropogenic sources such as automobile emissions, oil and (or) coal-fired generating stations, and municipal incinerators; and additional sodium and chloride come from spreading of road salt on highways in winter (Paciga and Jervis, 1976). Sulfate is indirectly produced from the burning of fossil fuels, which affects both sites with similar absolute concentrations (non-oceanic sulfate concentra- tions in precipitation were $1.11 \mathrm{mg} / \mathrm{L}$ at Princeton and $1.04 \mathrm{mg} / \mathrm{L}$ at Truro). Calcium, magnesium, and potassium ions generally are considered to be from soil dust (Gambell and Fisher, 1966; Pearson and Fisher, 1971) and from anthropogenic sources such as burning of coal or oil and various industrial processes (Granat, 1972).

The closest straight-line path from Princeton to the ocean lies to the east and south. The Connecticut coastline is about $121 \mathrm{~km}$ due south, the headwaters of Narragansett Bay are about $97 \mathrm{~km}$ due southeast, and Boston Harbor is about $72 \mathrm{~km}$ due east (fig. 1). Further, southeast winds predominate in many cyclonic storms at Princeton and Truro. Thus, for much of the storm duration, the winds blow over the Atlantic Ocean before reaching land. However, despite the prevailing winds and short distance inland, the oceanic contributions to precipitation quality are greatly reduced at Princeton. The calculated mean seawater concentrations in precipitation (table 11) at Princeton and Truro show that Princeton receives only 3.6 percent of the chloride, 4.0 percent of the sodium, 5.0 percent of the potassium, 5.1 percent of the magnesium, 8.0 percent of the sulfate, and 7.7 percent of the calcium concentrations received 
at Truro. Because of the lack of dissolved constituents at Princeton as compared to Truro, it seems reasonable to conclude that precipitation at Princeton contains a small component of seawater that is enriched with chemical constituents from land-based sources.

\section{Anthropogenic Effects}

Precipitation at Princeton primarily is a dilute solution of strong acids. The ionic composition of precipitation at the inland site in Princeton is about 50 percent hydrogen sulfate on a volume-weighted microequivalent basis. If the nitrate component also is considered, then ionic composition of precipitation is 60 percent hydrogen ion, sulfate, and nitrate; hence, precipitation at Princeton primarily is a dilute mixture of sulfuric and nitric acids. At the coastal site in Truro, hydrogen sulfate is only 15 percent of the total ionic composition of precipitation, and the addition of nitrate increases the percentage to 18 percent, which is much lower than at Princeton. Most of the sulfates in precipitation in the northeastern United States originate from two sources: the ocean (a natural source), and the combustion of fuels such as gasoline, coal, and oil (anthropogenic sources). Sulfate from the ocean is a direct transfer of the sulfate ion from the atmosphere. However, sulfate from fossil fuels is a chemical alteration in the atmosphere of a fraction of the combustion product sulfur dioxide to sulfuric acid. Similarly, nitrates in precipitation are derived from the chemical alteration in the atmosphere of nitrous oxides, emitted by fossil-fuel combustion and agricultural activities, to nitric acid.

Ninety-three percent of the sulfate in precipitation at Princeton was generated from non-oceanic sources on a volume-weighted mean basis. This was determined by subtracting the amount of sulfate in precipitation generated from oceanic origin, $0.07 \mathrm{mg} / \mathrm{L}$ (table 11 ), from the total amount of sulfate in precipitation, $1.18 \mathrm{mg} / \mathrm{L}$, leaving $1.11 \mathrm{mg} / \mathrm{L}$ derived mainly from anthropogenic sources (Galloway and Whelpdale, 1980).

If sulfates in precipitation were generated from the conversion of sulfur oxides to sulfuric acid, then there should be a direct relation between the logarithms of equivalent concentrations between hydrogen and sulfate ions in precipitation at Princeton. A regression of the logarithms of sulfate ion (anthropogenic plus oceanic origins) with the logarithms of hydrogen ion in precipitation yields a coefficient of determination $\left(r^{2}\right)$ of 62 percent; whereas a similar regression of sulfate ion in precipitation with the oceanic source removed (anthropogenic sulfate) yields an $r^{2}$ of 61 percent. Given the small amount of oceanic sulfate (7 percent) in precipitation at this site, this result is not surprising. This analysis supports the hypothesis that most of the hydrogen ion in precipitation is related to sulfur dioxides in the atmosphere (Munger and Eisenreich, 1983).

Other by-products of fuel combustion-particularly of oil and gasoline-are nitrous oxides, which are converted to nitric acid in the atmosphere, thereby forming the nitrate in precipitation. Consequently, there should be a relation between nitrate and hydrogen ions in precipitation because of the conversion of nitrous oxides to nitric acid in the atmosphere. Regression of the logarithms of hydrogen and nitrate ions in precipitation at Princeton produced an unexpectedly low $r^{2}$ of 42 percent. This low $r^{2}$ may be related to one of the following factors: (1) the equivalent concentration of anthropogenic sulfate ion is usually greater than that of nitrate ion on the order of two to one, (2) the ratio between the equivalents of anthropogenic sulfate and nitrate ions in storms is not constant but ranges from 0.2:1 to 19:1, and (3) ammonium ions emitted by agricultural activities may neutralize nitrate ions emitted by agricultural activities, obscuring the relation between nitrate and hydrogen ions in agricultural regions. Nitrate and sulfate contribute about 35 and 65 percent, respectively, to the acidity of the precipitation. In addition, the change in ratios between storms indicates that the cold and warm airmasses comprising storms have traveled over different source areas prior to yielding precipitation at Princeton; that is, the source areas for one storm may produce more sulfate emissions than nitrate emissions, and the source areas for another storm may produce more nitrate emissions than sulfate emissions. Summing both acid fractions (nitrate and anthropogenic sulfate) in precipitation and comparing the sum to total hydrogen ion in precipitation yields an $r^{2}$ of 71 percent. This coefficient is somewhat improved over the anthropogenic sulfate to hydrogen relation $\left(r^{2}=61\right.$ percent), but much better than the nitrate to hydrogen relation $\left(r^{2}=42\right.$ percent). The logarithmic plots of these relations are shown in figure 7. Thus, at Princeton, much of the hydrogen ion is related to the sulfate and nitrate fractions in precipitation. 

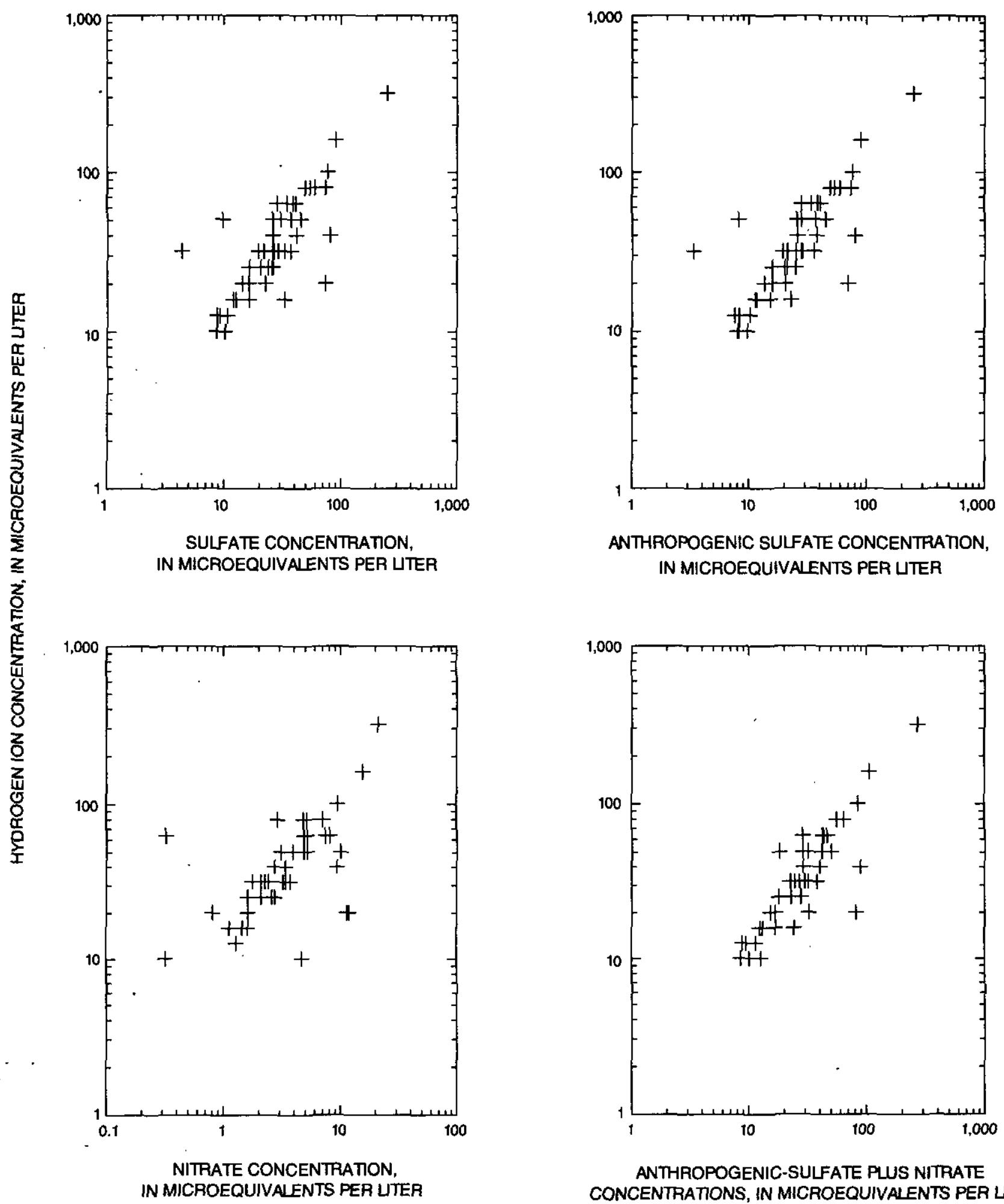

ANTHROPOGENIC SULFATE CONCENTRATION, IN MICROEQUIVALENTS PER UTER

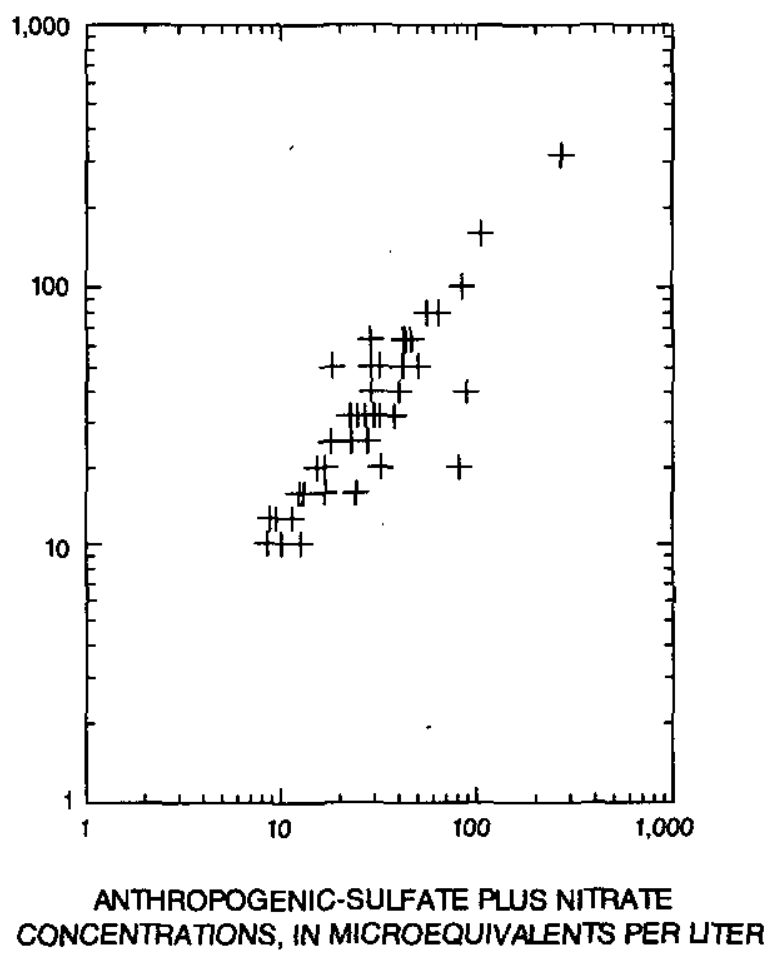

Figure 7. Relations between hydrogen ion concentration and nitrate concentration and (or) concentrations of several forms of sulfate in precipitation at Princeton, Massachusetts, 1983-85. 
Anthropogenic sources generated 54 percent of the sulfate in precipitation at Truro on a volume-weighted mean basis. This was determined by subtracting the amount of oceanic-source sulfate in precipitation, $0.88 \mathrm{mg} / \mathrm{L}$ (table 11) from the total amount of sulfate in precipitation, $1.92 \mathrm{mg} / \mathrm{L}$, leaving $1.04 \mathrm{mg} / \mathrm{L}$ derived from non-oceanic, primarily anthropogenic, sources. This amount compares well with the sulfate concentration in precipitation at Princeton from anthropogenic sources, $1.11 \mathrm{mg} / \mathrm{L}$. This slight difference in concentrations is reasonable because air over inland sites, such as Princeton, would not be well mixed with less contaminated ocean air because of the distance to the ocean.

The $r^{2}$ for the relation between hydrogen and sulfate ions in precipitation is 39 percent because of the large amount of sulfate from oceanic sources at Truro (46 percent). However, removing the effect of oceanic sources from precipitation samples, as was done at Princeton, and then regressing the logarithms of hydrogen ions with anthropogenic sulfate yields an $r^{2}$ of 78 percent, greatly improving the relation. In addition, the hydrogen-to-nitrate relation in precipitation at Truro has an $r^{2}$ of 57 percent, which is higher than that at Princeton $\left(r^{2}=42\right.$ percent) probably because of the greater distance to agricultural sources from Truro than from Princeton. Combining the nitrate and anthropogenic sulfate concentrations for all storms and regressing those values with hydrogen-ion concentrations yields an $r^{2}$ of 86 percent. This relation is stronger than that at Princeton $\left(r^{2}=71\right.$ percent). Relations at Truro are shown in figure 8. The coefficient of determination at each site indicates that most hydrogen ions at both sites are related to the nitrate and anthropogenic sulfate concentrations in precipitation.

The hydrogen-ion concentrations measured in precipitation are only a fraction of the amount of hydrogen ions released into the atmosphere. Hydrogen ions in the atmosphere are neutralized by contact with carbonatecontaining dust (calcium, magnesium, and potassium carbonates) and ammonia. The carbonate-containing substances dissolve in the acidic clouds and precipitation, where the carbonate fraction is converted to carbon dioxide and water. This process consumes hydrogen ions, but leaves calcium, magnesium, and potassium dissolved in precipitation. In addition, ammonia in the atmosphere is converted to ammonium ion by consuming a hydrogen ion in the process. The major source of carbonate-containing material in the atmosphere is soil dust (Gambell and Fisher, 1966). Ammonia in the atmosphere comes from bacterial action in soils (Granat, 1972), waste incineration, fossil-fuel combustion, and the decomposition of organic wastes such as sewage or animal wastes (Munger and Eisenreich, 1983). The calcium, magnesium, and potassium ions that originate from oceanic sources are bonded to chloride ions and are not available for hydrogen-ion neutralization (Granat, 1972). The remaining calcium, magnesium, and potassium ions originate from dust particles and bond to carbonate materials. Thus, for each microequivalent of non-oceanic calcium, magnesium, potassium, or ammonium ions measured in precipitation, one microequivalent of hydrogen ion has already been consumed.

For this discussion, volume-weighted mean concentrations are used; the percentage of the oceanicsource effect on precipitation at both sites is from table 11. In precipitation at Princeton, 50, 20, and 14 percent of the magnesium, potassium, and calcium, respectively, are of oceanic origin, leaving a residual of $5.3 \mu \mathrm{eq} / \mathrm{L}$ of non-oceanic calcium, magnesium, and potassium to be added to $6.1 \mu \mathrm{eq} / \mathrm{L}$ of ammonium ion. This represents $11.4 \mu \mathrm{eq} / \mathrm{L}$ of neutralized hydrogen ion or about 25 percent of the total hydrogen ion present in precipitation prior to neutralization. The $34.5 \mu \mathrm{eq} / \mathrm{L}$ of hydrogen ion measured in precipitation at Princeton represents about 75 percent of what was present prior to neutralization.

In precipitation at Truro, 95, 86, and 72 percent of the magnesium, potassium, and calcium, respectively, are of oceanic origin, leaving a residual of $4.7 \mu \mathrm{eq} / \mathrm{L}$ of non-oceanic calcium, magnesium, and potassium to be added to $5.5 \mu \mathrm{eq} / \mathrm{L}$ of ammonium ion. This represents $10.2 \mu \mathrm{eq} / \mathrm{L}$ of neutralized hydrogen ion or about 26 percent of the total hydrogen ion present in precipitation prior to neutralization. The $28.8 \mu \mathrm{eq} / \mathrm{L}$ of hydrogen ion measured in precipitation at Truro represents about 74 percent of what was present prior to neutralization. This analysis indicates that (1) about 55 percent of the neutralization capacity at both sites is derived from ammonia conversion to ammonium and not from carbonate-containing dust particles and (2) about the same relative amount of hydrogen ions is neutralized at both sites even though precipitation at Truro has lower hydrogen-ion concentrations. 

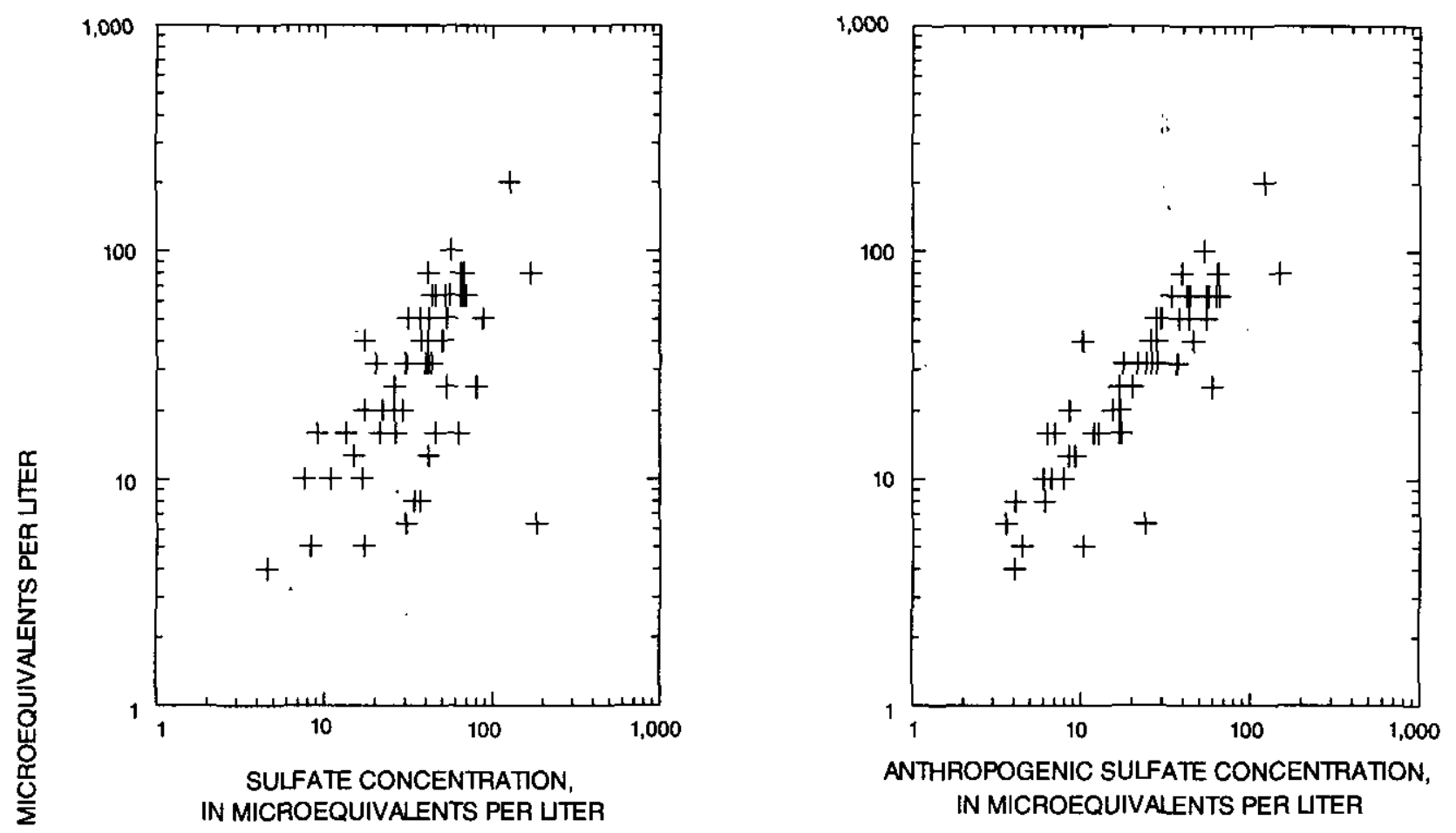

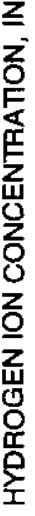
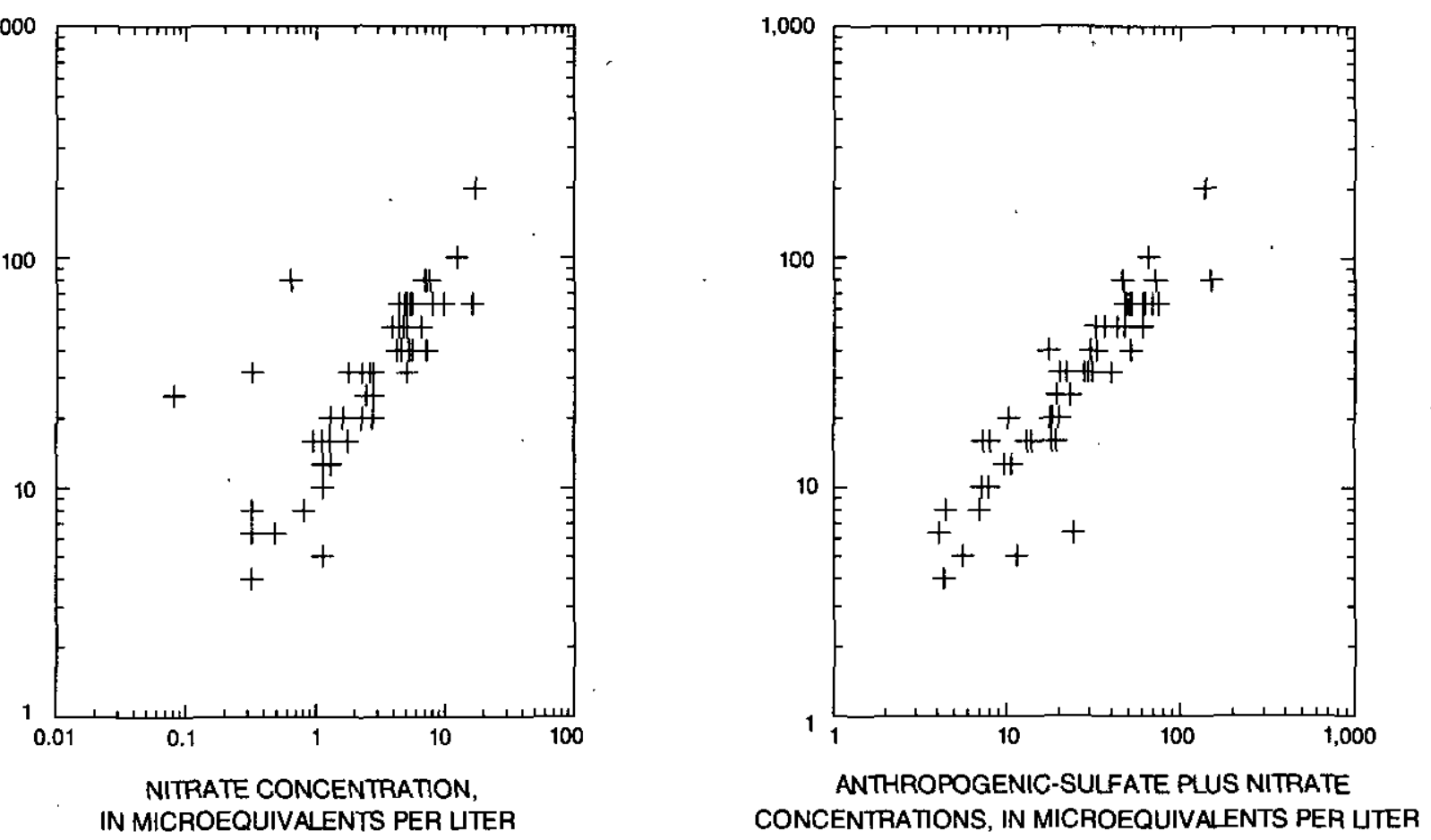

Figure 8. Relations between hydrogen ion concentration and nitrate concentration and (or) concentrations of several forms of sulfate in precipitation at Truro, Massachusetts, 1983-85. 


\section{Relation of Constituent Concentrations to Precipitation Depth}

As described in the section "Statistical Analysis of Concentration Data," light precipitation generally contains higher concentrations of dissolved constituents than does moderate to heavy precipitation. Plots of several common chemical constituents as a function of precipitation depth at Princeton and Truro are shown in figures 9 and 10 , respectively.

At Princeton, specific conductance and concentrations of hydrogen, nitrate, ammonium, potassium, sulfate, and calcium ions are highly variable at low precipitation depths, but the variability is reduced asymptotically at high precipitation depths (fig. 9). Concentrations of chloride, sodium, and magnesium ions, which are some of the major ions in ocean water, are not dependent on precipitation depth.

At Truro, specific conductance and concentrations of hydrogen, nitrate, ammonium, potassium, and sulfate (anthropogenic plus oceanic and anthropogenic only) ions follow the same trend of decreasing concentration with increasing precipitation depth determined for precipitation at Princeton (fig. 10). However, these relations are not as pronounced as at Princeton because of the effects of the Atlantic Ocean nearby. Chloride and sodium are about 70 percent of the dissolved constituents in precipitation at Truro and are not related to precipitation depth. Thus, it is reasonable to expect that specific conductance, which is a measure of the dissolved material in precipitation, will not show a pronounced relation with precipitation depth. The constituents for which concentrations show no relation to precipitation depth are calcium, chloride, sodium, magnesium, and oceanic sulfate, which are the major constituents in seawater. Concentrations of potassium, another major constituent in seawater, show a very weak relation to precipitation depth. The lack of relation seems to reflect the constant formation of aerosols of these constituents from the tops of ocean waves and the movement of the aerosols into the cold airmass beneath the cloud deck throughout the storm.

\section{Annual and Seasonal Constituent Concentrations and Loads}

Weekly composite chemical data from three precipitation-sampling sites in Massachusetts operated by the NADP were used to determine volume-weighted seasonal and annual mean concentrations and loads for common chemical constituents for spring 1983 through winter 1985. These sites (fig. 1) are at Quabbin Reservoir in western Massachusetts, at Waltham in eastern Massachusetts, and at the Truro site, where storm samples of precipitation also were collected. Annual and seasonal concentrations and loads for precipitation at Quabbin, Waltham, and Truro are shown in tables 1219. Sea-salt contributions to precipitation were not subtracted from the concentrations or loads at any of the sites because the determination of concentrations and loads falling on the land surface with precipitation was a primary objective. In addition, computed volumeweighted mean concentrations or loads for orthophosphate phosphorus in precipitation are less reliable estimates than the other constituent estimates in the tables because nearly all the orthophosphate phosphorus concentrations in precipitation samples were reported as less than the detection limit $(0.003 \mathrm{mg} / \mathrm{L})$ and converted to one-half of the detection limit prior to computations, as previously described.

Two sets of volume-weighted mean concentrations and loads in precipitation are shown for each constituent at each site. One set of mean concentrations and loads was computed by use of the precipitation amount determined from the standard Belfort weighing rain gage at each site (see "gage" entries in tables 12-19); the other set was computed by use of the precipitation amount determined from the bucket in which the precipitation sample was collected for chemical analysis (see "bucket" entries in tables 12-19). This approach was followed because many differences were found in precipitation amounts between the two data sets, and the gage amount was always higher. The differences probably result from the constant exposure of the Belfort precipitation gage to the atmosphere; whereas the sampling bucket is kept covered except during periods of precipitation when a sensor opens and closes the bucket in response to precipitation. Apparently, these sensors sometimes caused the sampling bucket to open late after the start of precipitation. In most instances, these differences in precipitation amount caused little or no difference $(0.02 \mathrm{mg} / \mathrm{L}$ or less) between the gage and bucket volume-weighted mean concentrations, but some of the differences in volume-weighted mean concentrations were substantial; for example, $0.68 \mathrm{mg} / \mathrm{L}$ for sulfate during winter 1984 at Quabbin (table 12). 

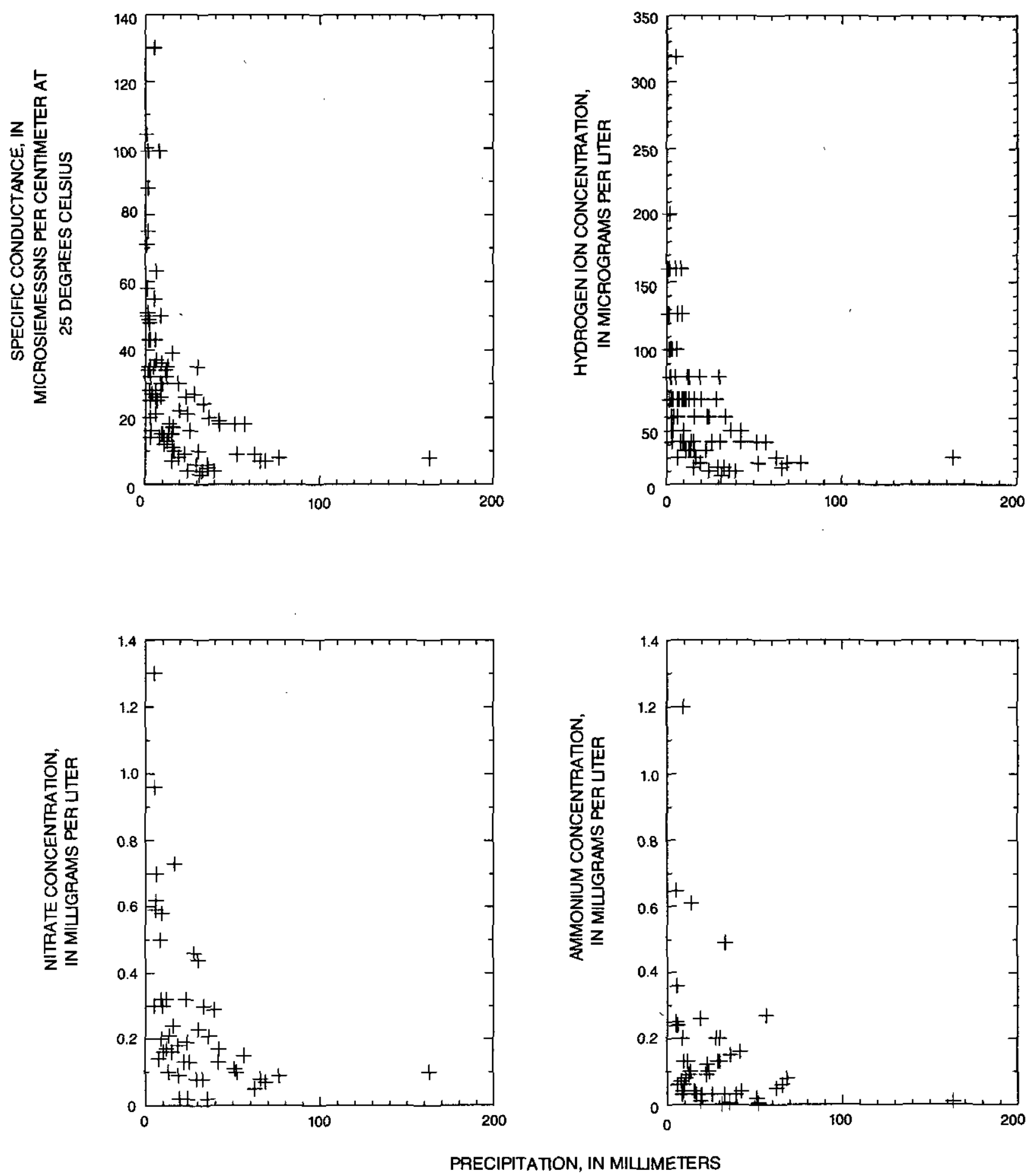

Figure 9. Relations between concentrations of various constituents in precipitation and depth of storm precipitation at Princeton, Massachusetts, 1983-85. 

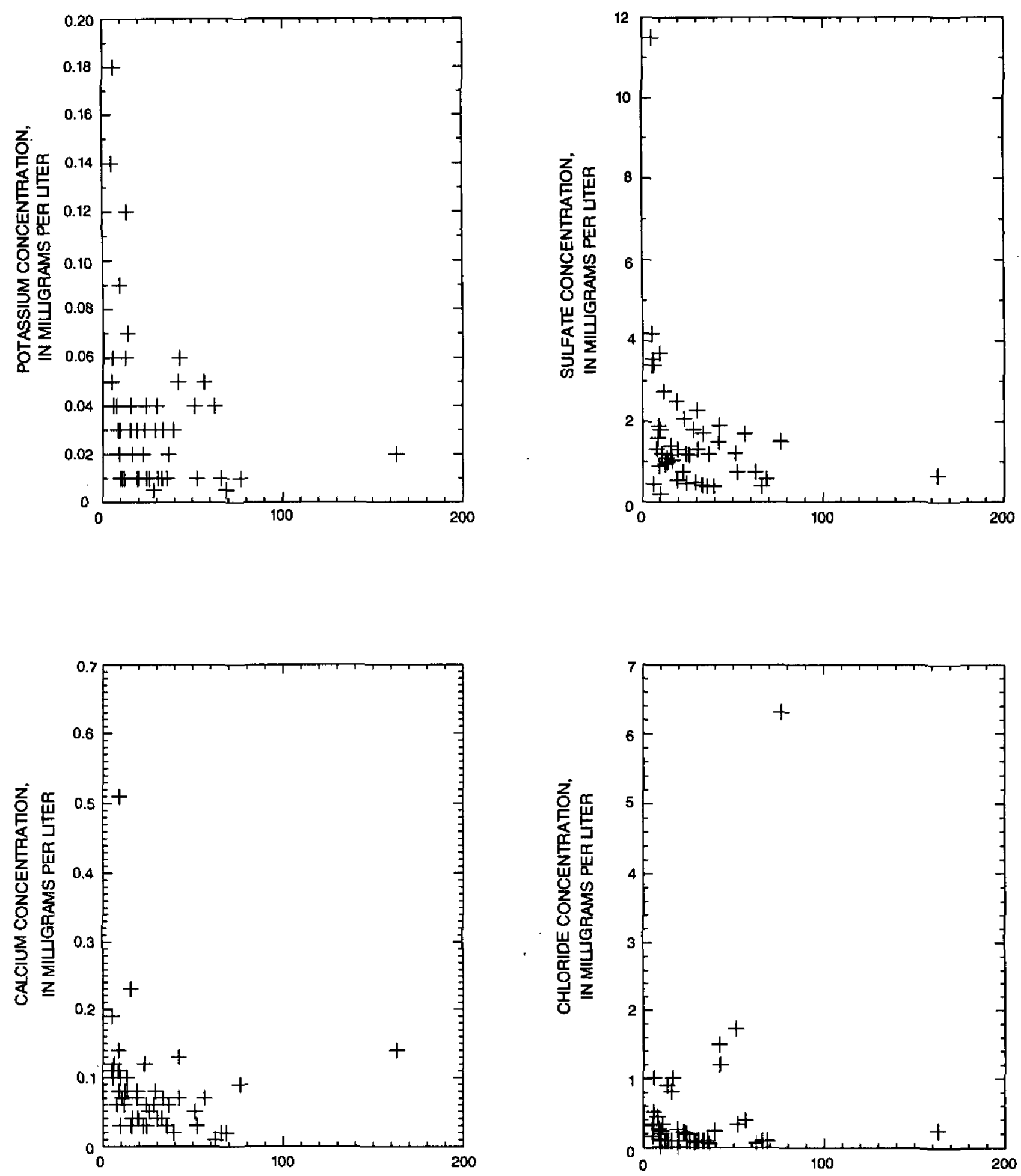

PRECIPITATION, IN MIUMETERS

Figure 9. Relations between concentrations of various constituents in precipitation and depth of storm precipitation at Princeton, Massachusetts, 1983-85.--Continued 


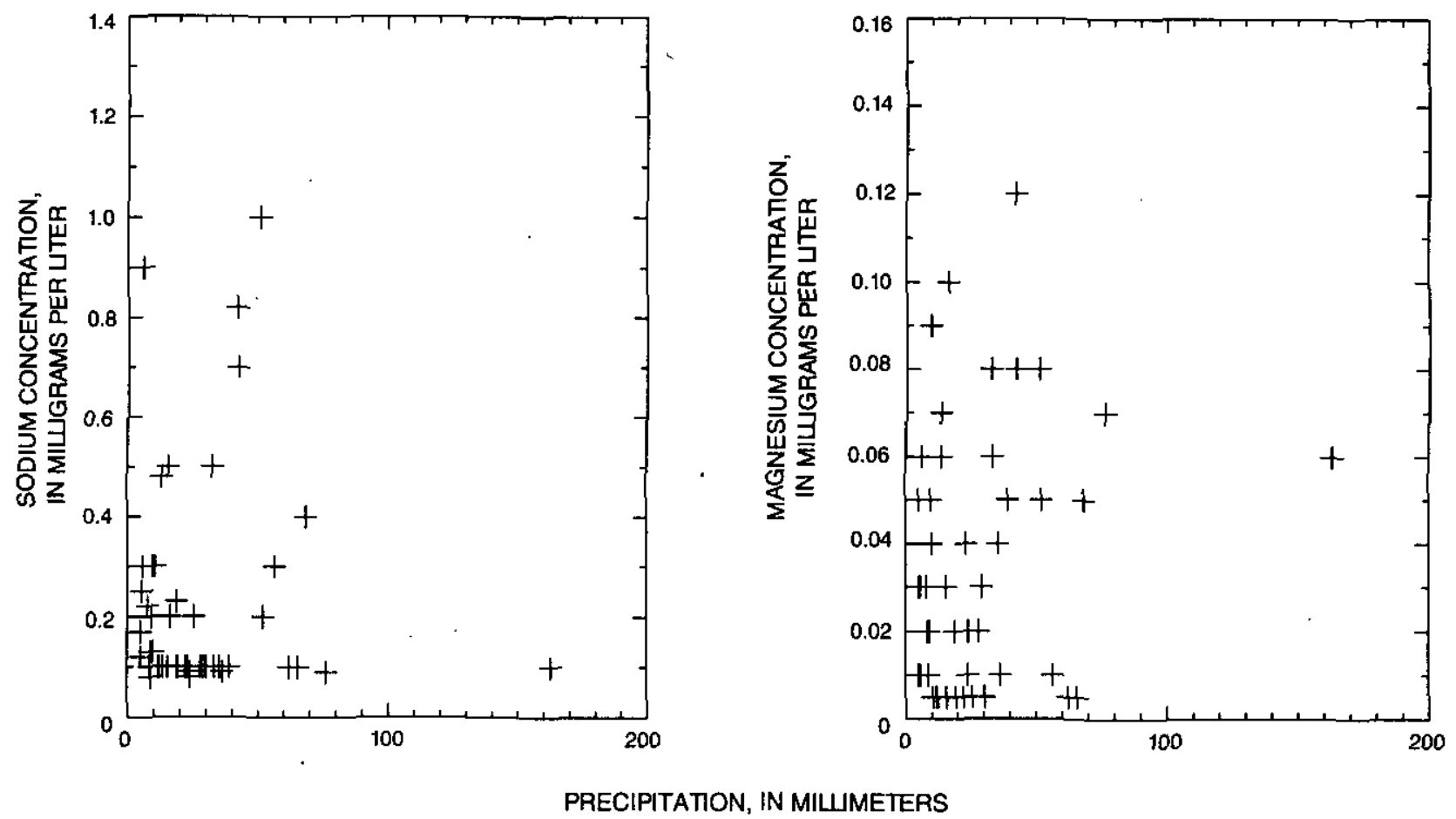

Figure 9. Relations between concentrations of various constituents in precipitation and depth of storm precipitation at Princeton, Massachusetts, 1983-85.--Continued

However, small differences in concentrations can produce large differences in loads. For example, during summer 1983 at Quabbin (table 12) a $0.06 \mathrm{mg} / \mathrm{L}$ difference in volume-weighted mean sulfate concentrations in precipitation between gage and bucket $(4.26$ to $4.20 \mathrm{mg} / \mathrm{L}$ ) resulted in a $120 \mathrm{mg} / \mathrm{m}^{2}$ difference in gage and bucket sulfate loads ( 767 to $647 \mathrm{mg} / \mathrm{m}^{2}$ ).

Volume-weighted mean concentrations indicate that concentrations of all constituents in precipitation except for orthophosphate phosphorus (calcium, magnesium, potassium, sodium, ammonium, nitrate, chloride, sulfate, and hydrogen) vary from season to season, year to year, and site to site. Orthophosphate phosphorus $\left(\mathrm{PO}_{4}\right)$ does not vary much in concentrations seasonally or by location because, for the most part, it is not present at the detection limit in the atmosphere above Massachusetts. Some constituents, such as calcium, magnesium, and potassium, are present in precipitation at low concentrations, and absolute changes in concentration from season to season are small. This pattern is indicative of nonvariable, ubiquitous sources. Other constituents, such as sulfate, are present in precipitation at higher concentrations, and absolute changes in concentration from season to season are much larger. This pattern is indicative of point sources that are probably of local or regional origin. Variations in constituent concentration in precipitation result because source concentrations vary with time of year, rain more effectively removes particulates from the atmosphere than does snow, air currents follow different flow paths for each storm, and atmospheric conditions (which affect the transformation of constituents) vary with time of year.

Even though some constituents in precipitation are at low concentrations during one season of the year and significantly higher concentrations at another season of the year, loads computed from these concentrations may not follow the same pattern. Sometimes, differences in precipitation depth between sites reduce rather than follow or increase the differences in concentration. 

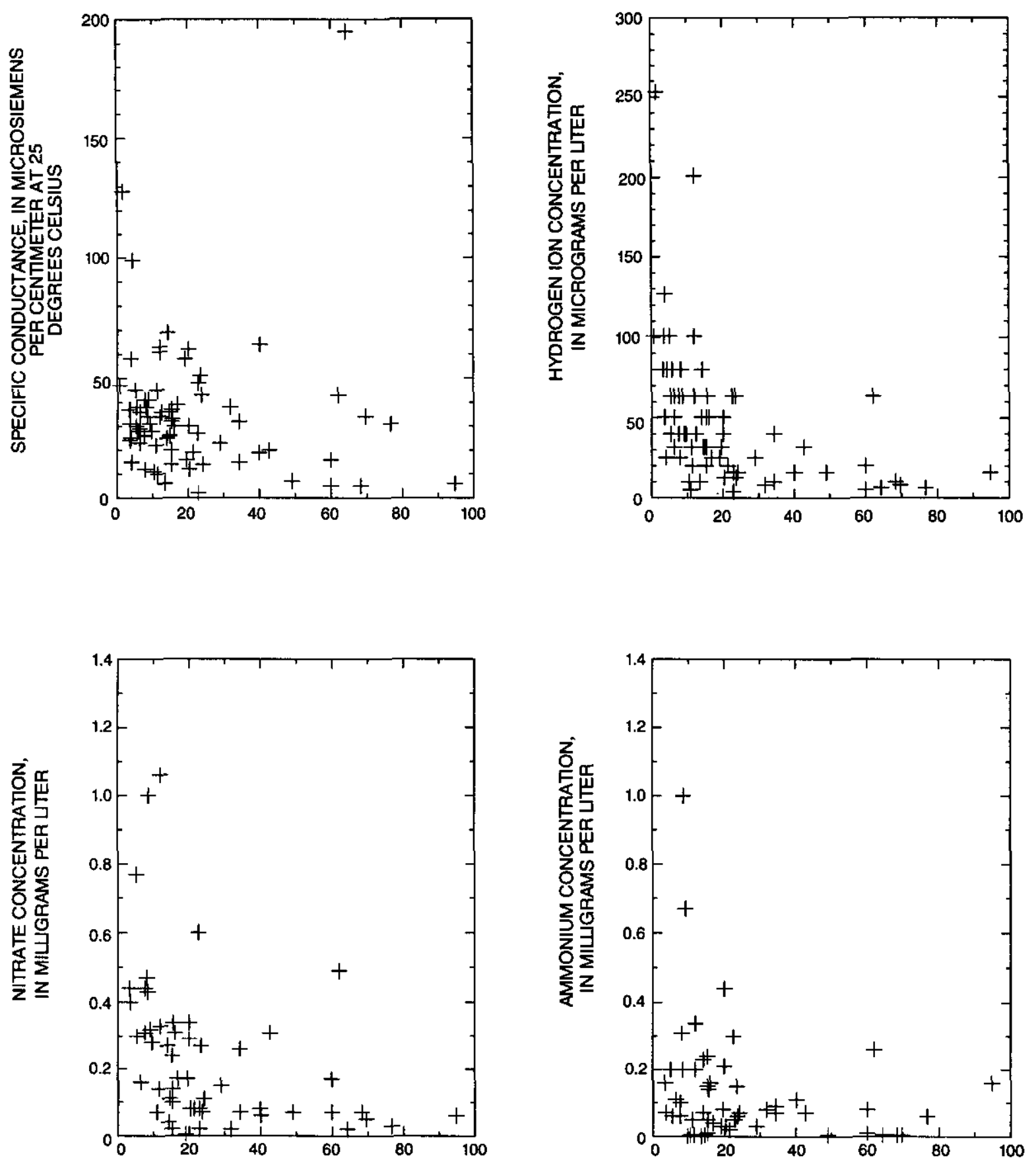

PRECIPITATION, IN MIUMETERS

Figure 10. Relations between concentrations of varlous constituents in precipitation and depth of storm precipitation at Truro. Massachusetts, 1983-85. 

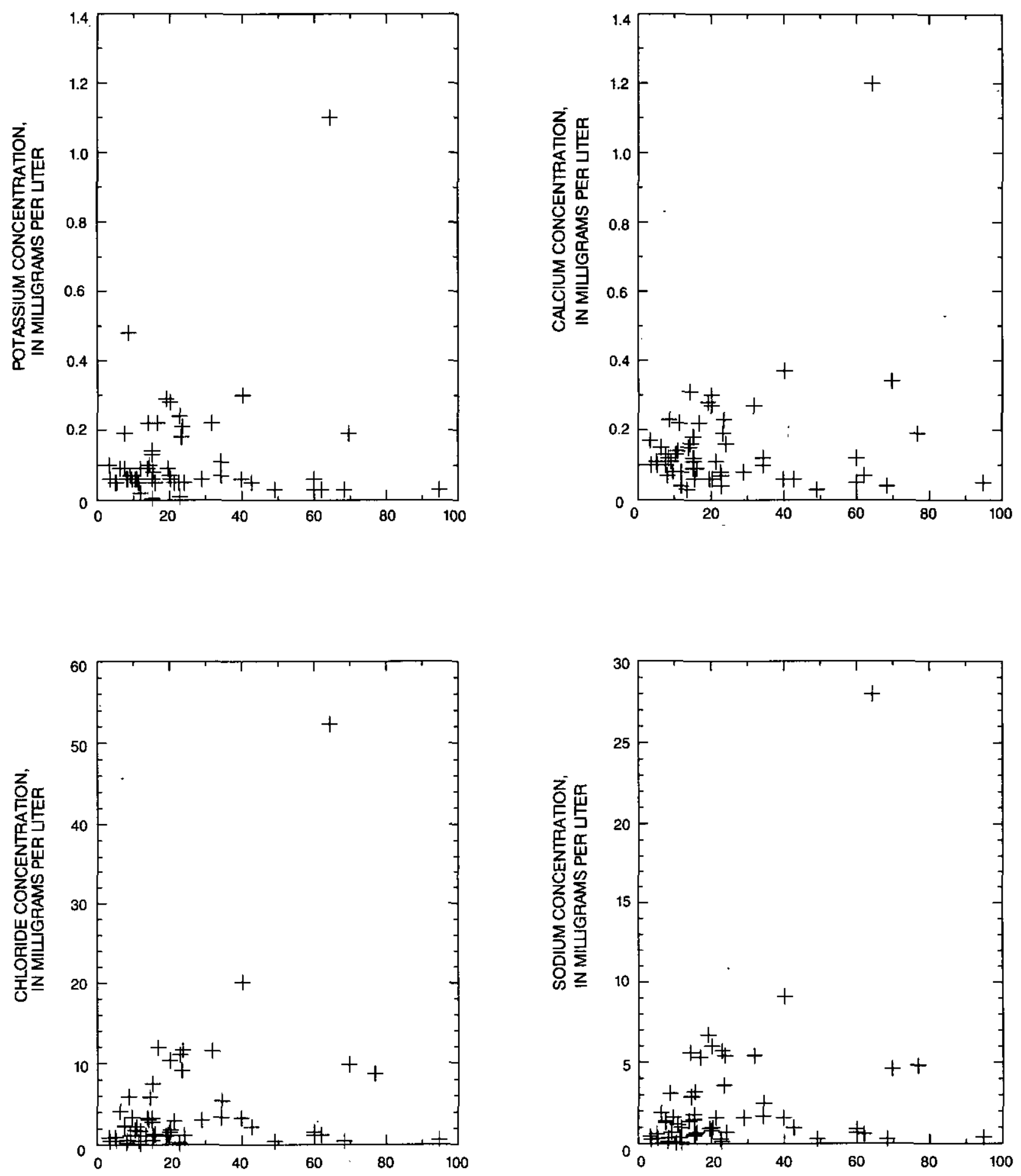

PRECIPITATION, IN MIUMMETERS

Figure 10. Relations between concentrations of various constituents in precipitation and depth of storm precipitation at Truro, Massachusetts, 1983-85--Continued. 

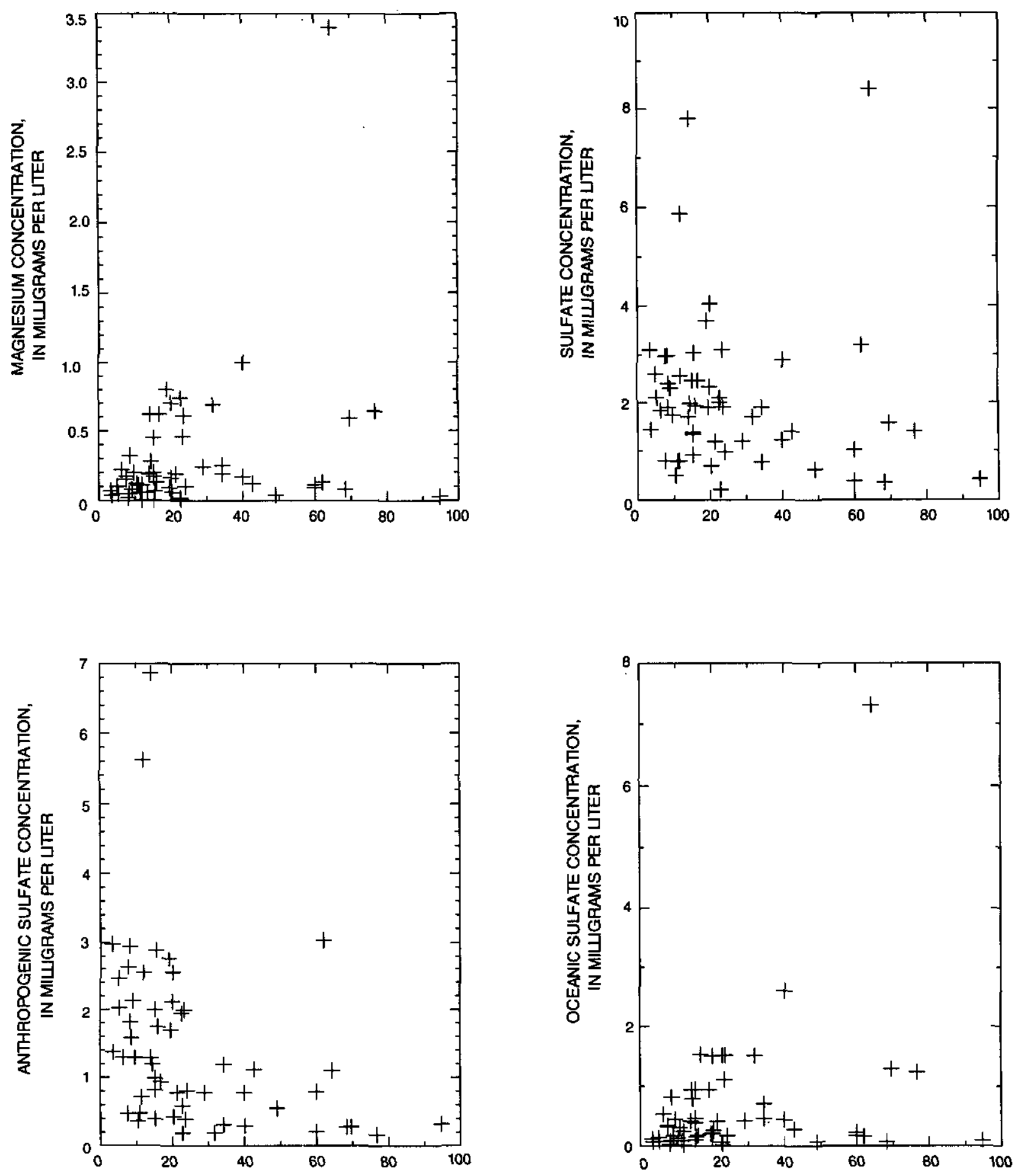

PRECIPITATION, IN MIUMETERS

Figure 10. Relations between concentrations of various constituents in precipitation and depth of storm precipitation at Truro, Massachusetts, 1983-85--Continued. 


\begin{tabular}{|c|c|c|c|c|c|c|c|c|c|c|c|c|c|}
\hline \multicolumn{14}{|c|}{ 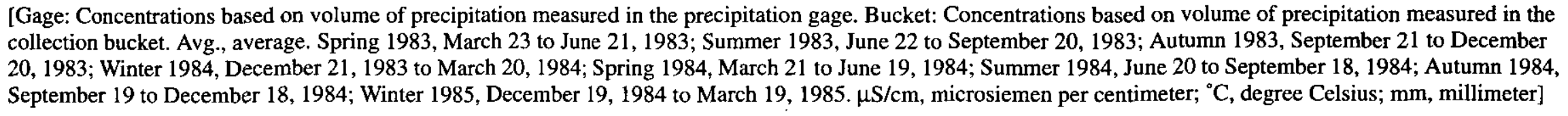 } \\
\hline \multirow{3}{*}{\multicolumn{2}{|c|}{$\begin{array}{l}\text { Precipitation characteristic or } \\
\text { chemical constituent }\end{array}$}} & \multicolumn{12}{|c|}{ Volume-weighted mean (concentrations in milligrams per liter, except as noted) } \\
\hline & & \multicolumn{3}{|c|}{ Spring } & \multicolumn{3}{|c|}{ Summer } & \multicolumn{3}{|c|}{ Autumn } & \multicolumn{3}{|c|}{ Winter } \\
\hline & & 1983 & 1984 & Avg. & 1983 & 1984 & Avg. & 1983 & 1984 & Avg. & 1984 & 1985 & Avg. \\
\hline \multirow[t]{2}{*}{ Precipitation, in $\mathrm{mm}$} & (gage) & 427 & 474 & 450 & 180 & 277 & 228 & 489 & 217 & 353 & 344 & 220 & 282 \\
\hline & (bucket) & 317 & 409 & 363 & 154 & 263 & 209 & 410 & 202 & 306 & 208 & 170 & 189 \\
\hline \multirow{2}{*}{$\begin{array}{l}\text { Specific conductance, } \\
\text { in } \mu \mathrm{S} / \mathrm{cm} \text { at } 25^{\circ} \mathrm{C}\end{array}$} & (gage) & 35.4 & 29.4 & 33.4 & 50.8 & 33.3 & 39.8 & 12.1 & 24.0 & 15.8 & 35.6 & 30.8 & 33.9 \\
\hline & (bucket) & 32.8 & 30.3 & 32.0 & 50.2 & 30.4 & 37.8 & 11.9 & 24.4 & 15.9 & 23.2 & 30.3 & 26.0 \\
\hline \multirow[t]{2}{*}{$\mathrm{pH}$, in standard units } & (gage) & 4.18 & 4.24 & 4.20 & 3.94 & 4.13 & 4.05 & 4.57 & 4.39 & 4.50 & 4.08 & 4.25 & 4.13 \\
\hline & (bucket) & 4.20 & 4.23 & 4.21 & 3.95 & 4.16 & $4: 07$ & 4.57 & 4.39 & 4.50 & 4.28 & 4.26 & 4.27 \\
\hline \multirow[t]{2}{*}{ Hydrogen ions } & (gage) & .067 & .057 & .063 & .115 & .075 & .089 & .027 & .041 & .032 & .083 & .057 & .074 \\
\hline & (bucket) & .064 & .059 & .062 & .114 & .070 & .086 & .027 & .041 & .032 & .053 & .056 & .054 \\
\hline \multirow[t]{2}{*}{ Calcium } & (gage) & .13 & .08 & .10 & .14 & .10 & .11 & .19 & .17 & .18 & .16 & .11 & .14 \\
\hline & (bucket) & .11 & .08 & .09 & .13 & .09 & .10 & .04 & .09 & .06 & .10 & .10 & .10 \\
\hline \multirow[t]{2}{*}{ Magnesium } & (gage) & .050 & -.031 & .038 & .041 & .039 & .040 & .061 & .061 & .061 & .052 & .036 & .046 \\
\hline & (bucket) & .044 & .030 & .036 & .039 & .037 & .038 & .028 & .044 & .034 & .043 & .035 & .040 \\
\hline \multirow[t]{2}{*}{ Sodium } & (gage) & .203 & .132 & .161 & .076 & .104 & .094 & .233 & .273 & .247 & .254 & .200 & .235 \\
\hline & (bucket) & .198 & .126 & .154 & .074 & .093 & .086 & .180 & .228 & .198 & .272 & .193 & .241 \\
\hline \multirow[t]{2}{*}{ Potassium } & (gage) & .094 & .023 & .051 & .028 & .033 & .031 & .025 & .054 & .035 & .029 & .017 & .025 \\
\hline & (bucket) & .085 & .023 & .047 & .025 & .032 & .029 & .014 & .048 & .026 & .018 & .017 & .018 \\
\hline \multirow[t]{2}{*}{ Sulfate } & (gage) & 3.20 & 1.55 & 2.22 & 4.26 & 2.79 & 3.31 & 1.29 & 1.93 & 1.51 & 2.16 & 2.01 & 2.11 \\
\hline & (bucket) & 2.85 & 1.57 & 2.07 & 4.20 & 2.59 & 3.17 & .95 & 1.71 & 1.23 & 1.48 & 1.92 & 1.65 \\
\hline \multirow[t]{2}{*}{ Chloride } & (gage) & .36 & .24 & .29 & .17 & .33 & .28 & .38 & .41 & .39 & .51 & .36 & .46 \\
\hline & (bucket) & .36 & .23 & .28 & .16 & .32 & .26 & .33 & .35 & .34 & .49 & .36 & .44 \\
\hline \multirow[t]{2}{*}{ Nitrate, as nitrogen } & (gage) & .42 & .27 & .33 & .57 & .45 & .49 & .27 & .35 & .30 & .62 & .47 & .56 \\
\hline & (bucket) & .40 & .28 & .33 & .56 & .41 & .46 & .16 & .30 & .21 & .36 & .47 & .40 \\
\hline \multirow[t]{2}{*}{ Ammonium, as nitrogen } & (gage) & .30 & .14 & .21 & .23 & .18 & .20 & .07 & .18 & .11 & .12 & .12 & .12 \\
\hline & (bucket) & .28 & .15 & .20 & .23 & .17 & .19 & .04 & .16 & .08 & .07 & .12 & .09 \\
\hline \multirow{2}{*}{$\begin{array}{l}\text { Orthophosphate }{ }^{1} \text {, as } \\
\text { phosphorus }\end{array}$} & (gage) & .001 & .003 & .002 & .002 & .002 & .002 & .003 & .002 & .003 & .002 & .002 & .002 \\
\hline & (bucket) & .002 & .003 & .002 & .002 & .002 & .002 & .002 & .002 & .002 & .002 & .002 & .002 \\
\hline
\end{tabular}

\footnotetext{
${ }^{1}$ Orthophosphate concentrations are less reliable estimates because a large number of samples with concentrations less than the detection limit were utilized.
} 
Table 13. Seasonal constituent loads in precipitation at the National Atmospheric Deposition Program site at Quabbin Reservoir, Massachusetts, spring 1983 through winter 1985

[Gage: Loads based on volume of precipitation measured in the precipitation gage. Bucket: Loads based on volume of precipitation measured in the collection bucket. Avg, average. Spring 1983, March 23 to June 21, 1983; Summer 1983, June 22 to September 20, 1983; Autumn 1983, September 21 to December 20, 1983; Winter 1984, December 21, 1983 to March 20, 1984; Spring 1984, March 21 to June 19, 1984; Summer 1984, June 20 to September 18, 1984; Autumn 1984, September 19 to December 18, 1984; Winter 1985, December 19, 1984 to March 19, 1985]

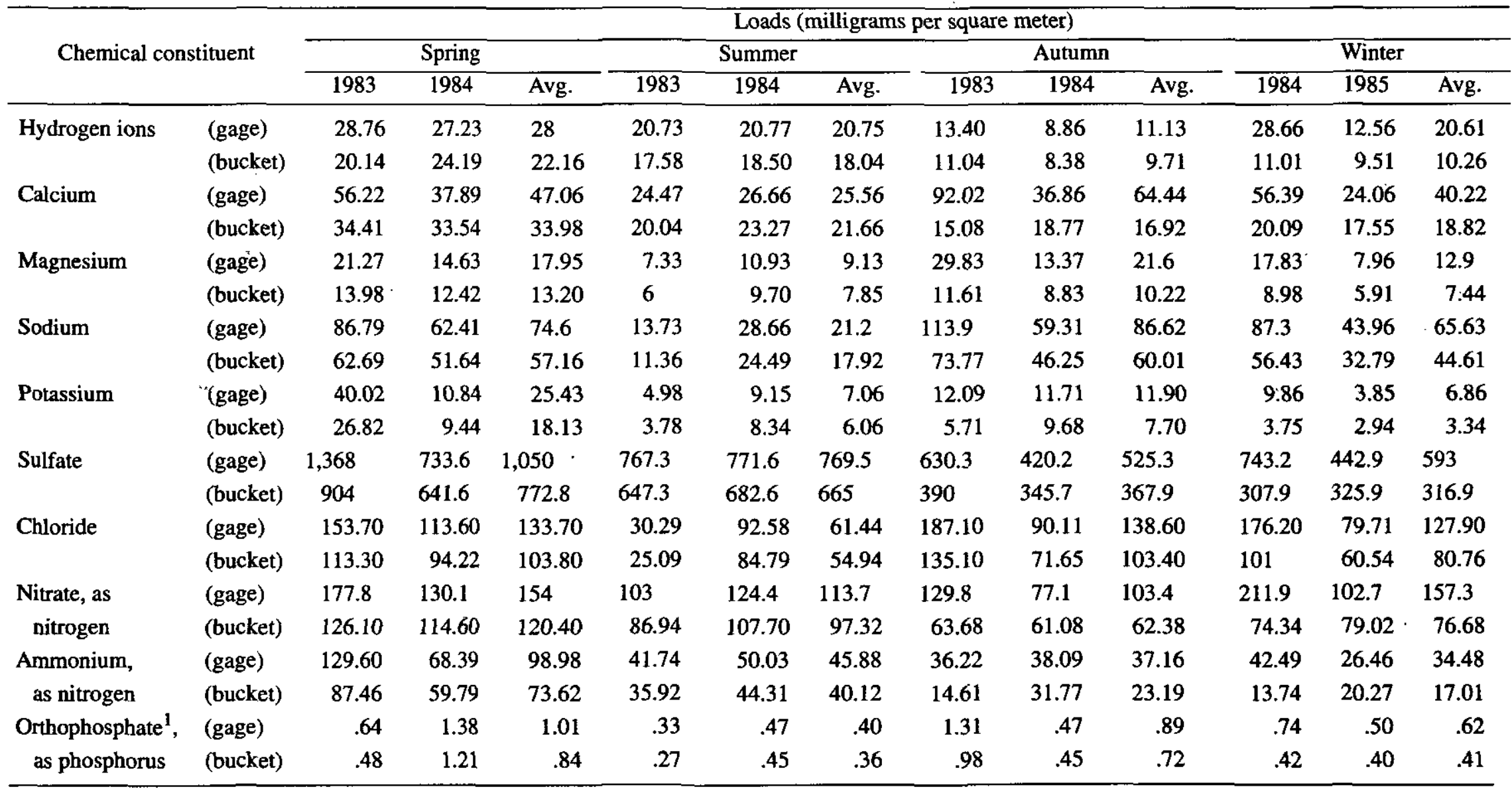

\footnotetext{
${ }^{1}$ Orthophosphate loads are less reliable estimates because a large number of samples with concentrations less than the detection limit were utilized.
} 
Table 14. Seasonal precipitation characteristics and constituent concentrations at the National Atmospheric Deposition Program site at Waltham, Massachusetts, spring 1983 through winter 1985

[Gage: Concentrations based on volume of precipitation measured in the precipitation gage. Bucket: Concentrations based on volume of precipitation measured in the collection bucket; Avg., average. Spring 1983, March 23 to June 21, 1983; Summer 1983, June 22 to September 20, 1983; Autumn 1983, September 21 to December 20, 1983; Winter 1984, December 21, 1983 to March 20, 1984; Spring 1984, March 21 to June 19, 1984; Summer 1984, June 20 to September 18, 1984; Autumn 1984, September 19 to December 18, 1984; Winter 1985, December 19, 1984 to March 19, 1985. $\mu \mathrm{S} / \mathrm{cm}$, microsiemen per centimeter; ${ }^{\circ} \mathrm{C}$, degree Celsius; mm, millimeter.]

\begin{tabular}{|c|c|c|c|c|c|c|c|c|c|c|c|c|c|}
\hline \multirow{3}{*}{\multicolumn{2}{|c|}{$\begin{array}{l}\text { Precipitation characteristic or } \\
\text { chemical constituent }\end{array}$}} & \multicolumn{12}{|c|}{ Volume-weighted mean (in milligrams per liter, except as noted) concentrations } \\
\hline & & \multicolumn{3}{|c|}{ Spring } & \multicolumn{3}{|c|}{ Summer } & \multicolumn{3}{|c|}{ Autumn } & \multicolumn{3}{|c|}{ Winter } \\
\hline & & 1983 & 1984 & Avg. & 1983 & 1984 & Avg. & 1983 & 1984 & Avg. & 1984 & 1985 & Avg. \\
\hline \multirow[t]{2}{*}{ Precipitation, in $\mathrm{mm}$} & (gage) & 297 & 397 & 347 & 159 & 243 & 201 & 434 & 189 & 312 & 388 & 150 & $269^{\circ}$ \\
\hline & (bucket) & 291 & 378 & 335 & 151 & 241 & 196 & 432 & 194 & 313 & 381 & 146 & 263 \\
\hline \multirow{2}{*}{$\begin{array}{l}\text { Specific conductance, } \\
\text { in } \mu \mathrm{S} / \mathrm{cm} \text { at } 25^{\circ} \mathrm{C}\end{array}$} & (gage) & 31.7 & 28.7 & 30 & 54.9 & 48.2 & 50.8 & 23.9 & 18.8 & 22.8 & 25.3 & 28.4 & 26.2 \\
\hline & (bucket) & 31.4 & 29 & 30.1 & 54.8 & 48.6 & 51 & 23.7 & 18.9 & 22.6 & 25.4 & 28.5 & 26.3 \\
\hline \multirow[t]{2}{*}{$\mathrm{pH}$, in standard units } & (gage) & 4.68 & 4.48 & 4.56 & 4.12 & 4.23 & 4.18 & 4.62 & 4.62 & 4.62 & 4.46 & 4.41 & 4.45 \\
\hline & (bucket) & 4.68 & 4.47 & 4.55 & 4.11 & 4.22 & 4.18 & 4.62 & 4.62 & 4.62 & 4.47 & 4.41 & 4.45 \\
\hline \multirow[t]{2}{*}{ Hydrogen ions } & (gage) & .021 & .033 & .028 & .077 & .060 & .067 & .024 & .024 & .024 & .035 & .039 & .036 \\
\hline & (bucket) & .021 & .034 & .028 & .078 & .061 & .067 & .024 & .024 & .024 & .034 & .039 & .036 \\
\hline \multirow[t]{2}{*}{ Calcium } & (gage) & .10 & .09 & .10 & .15 & .09 & .11 & .06 & .06 & .06 & .06 & .08 & .07 \\
\hline & (bucket) & .10 & .10 & .10 & .15 & .09 & .11 & .06 & .06 & .06 & .06 & .08 & .07 \\
\hline \multirow[t]{2}{*}{ Magnesium } & (gage) & .082 & .053 & .066 & .061 & .048 & .053 & .071 & .075 & .072 & .046 & .080 & .055 \\
\hline & (bucket) & .082 & .055 & .067 & .061 & .048 & .053 & .070 & .074 & .071 & .045 & .083 & .056 \\
\hline \multirow[t]{2}{*}{ Sodium } & (gage) & .532 & .317 & .409 & .219 & .211 & .214 & .514 & .536 & 519 & .319 & .621 & .403 \\
\hline & (bucket) & .532 & .316 & .410 & .222 & .212 & .216 & .505 & .531 & .511 & .314 & .647 & .405 \\
\hline \multirow[t]{2}{*}{ Potassium } & (gage) & .033 & .026 & .029 & .030 & .022 & .025 & .026 & .030 & .027 & .019 & .031 & .022 \\
\hline & (bucket) & .032 & .026 & .029 & .030 & .023 & .025 & .026 & .030 & .027 & .018 & .031 & .022 \\
\hline \multirow[t]{2}{*}{ Sulfate } & (gage) & 2.15 & 1.75 & 1.92 & 3.59 & 2.92 & 3.18 & 1.38 & 1.28 & 1.36 & 1.37 & 1.90 & 1.52 \\
\hline & (bucket) & 2.13 & 1.80 & 1.94 & 3.59 & 2.97 & 3.21 & 1.37 & 1.28 & 1.35 & 1.38 & 1.95 & 1.53 \\
\hline \multirow[t]{2}{*}{ Chloride } & (gage) & 1 & .68 & .81 & 1.00 & .55 & .73 & 1 & .96 & .99 & .58 & 1.16 & .74 \\
\hline & (bucket) & - & .73 & .85 & .95 & .56 & .71 & .98 & .95 & .98 & .57 & 1.20 & .74 \\
\hline \multirow[t]{2}{*}{ Nitrate, as nitrogen } & (gage) & .24 & .19 & .21 & .47 & .34 & .39 & .11 & .08 & .11 & .15 & .30 & .19 \\
\hline & (bucket) & .23 & .20 & .21 & .47 & .35 & .39 & .11 & .08 & .11 & .14 & .29 & .18 \\
\hline \multirow[t]{2}{*}{ Ammonium, as nitrogen } & (gage) & .11 & .07 & .09 & .16 & .17 & .17 & .04 & .04 & .04 & .06 & .08 & .06 \\
\hline & (bucket) & .11 & .08 & .09 & .16 & .17 & .17 & .04 & .04 & .04 & .06 & .09 & .06 \\
\hline \multirow{2}{*}{$\begin{array}{l}\text { Orthophosphate }{ }^{1} \text {, as } \\
\text { phosphorus }\end{array}$} & (gage) & .001 & .001 & .001 & .002 & .002 & .002 & .005 & .003 & .004 & .001 & .002 & .002 \\
\hline & (bucket) & .001 & .002 & .002 & .002 & .002 & .002 & .005 & .003 & .005 & .001 & .002 & .002 \\
\hline
\end{tabular}

\footnotetext{
${ }^{1}$ Orthophosphate concentrations are less reliable estimates because a large number of samples with concentrations less than the detection limit were utilized.
} 
Table 15. Seasonal constituent loads in precipitation at the National Atmospheric Deposition Program site at Waltham, Massachusetts, spring 1983 through winter 1985

[Gage: Loads based on volume of precipitation measured in the precipitation gage. Bucket: Loads based on volume of precipitation measured in the collection bucket. Avg., average. Spring 1983, March 23 to June 21, 1983; Summer 1983, June 22 to September 20, 1983; Autumn 1983, September 21 to December 20, 1983; Winter 1984, December 21, 1983 to March 20, 1984; Spring 1984, March 21 to June 19, 1984; Summer 1984, June 20 to September 18, 1984; Autumn 1984, September 19 to December 18, 1984; Winter 1985, December 19, 1984 to March 19, 1985]

\begin{tabular}{|c|c|c|c|c|c|c|c|c|c|c|c|c|c|}
\hline \multirow{3}{*}{\multicolumn{2}{|c|}{ Chemical constituent }} & \multicolumn{12}{|c|}{ Loads (milligrams per square meter) } \\
\hline & & \multicolumn{3}{|c|}{ Spring } & \multicolumn{3}{|c|}{ Summer } & \multicolumn{3}{|c|}{ Autumn } & \multicolumn{3}{|c|}{ Winter } \\
\hline & & 1983 & 1984 & Avg. & 1983 & 1984 & Avg. & 1983 & 1984 & Avg. & 1984 & 1985 & Avg. \\
\hline \multirow[t]{2}{*}{ Hydrogen ions } & (gage) & 6.27 & 13.18 & 9.72 & 12.24 & 14.53 & 13.38 & 10.44 & 4.55 & 7.50 & 13.46 & 5.93 & 9.70 \\
\hline & (bucket) & 6.08 & 12.98 & 9.53 & 11.69 & 14.68 & 13.18 & 10.37 & 4.66 & 7.52 & 13.02 & 5.73 & 9.38 \\
\hline \multirow[t]{2}{*}{ Calcium } & (gage) & 31.23 & 37.05 & 34.14 & 23.64 & 21.26 & 22.45 & 27.08 & 10.80 & 18.94 & 24.52 & 12.07 & 18.30 \\
\hline & (bucket) & 30.05 & 38.80 & 34.42 & 22.07 & 21.31 & 21.69 & 26.60 & 11.02 & 18.91 & 23.52 & 11.75 & 17.64 \\
\hline \multirow[t]{2}{*}{ Magnesium } & (gage) & 24.33 & 21.25 & 22.79 & 9.66 & 11.65 & 10.66 & 31 & 14.13 & 22.56 & 17.76 & 12.06 & 14.91 \\
\hline & (bucket) & 23.72 & 20.94 & 22.33 & 9.12 & 11.6 & 10.36 & 30.34 & 14.32 & 22.33 & 17.20 & 12.19 & 14.70 \\
\hline \multirow[t]{2}{*}{ Sodium } & (gage) & 158.20 & 125.90 & 142.10 & 34.76 & 51.44 & 43.10 & 223.10 & 101.50 & 162.30 & 123.60 & 93.48 & 108.50 \\
\hline & (bucket) & 154.60 & 119.80 & 137.20 & 33.41 & 51.17 & 42.29 & 218 & 102.70 & 160.40 & 119.60 & 94.59 & 107.10 \\
\hline \multirow[t]{2}{*}{ Potassium } & (gage) & 9.71 & 10.28 & 10 & 4.73 & 5.45 & 5.09 & 11.41 & 5.77 & 8.59 & 7.26 & 4.62 & 5.94 \\
\hline & (bucket) & 9.39 & 10 & 9.70 & 4.51 & 5.45 & 4.98 & 11.24 & 5.86 & 8.55 & 6.83 & 4.56 & 5.70 \\
\hline \multirow[t]{2}{*}{ Sulfate } & (gage) & 639.1 & 696.6 & 667.8 & 569.3 & 710.8 & 640.1 & 597 & 242.6 & 419.8 & 531.5 & 285.4 & 408.5 \\
\hline & (bucket) & 618.2 & 680.9 & 649.5 & 541.5 & 716 & 628.8 & 589.9 & 248.5 & 419.2 & 524.1 & 284.3 & 404.2 \\
\hline \multirow[t]{2}{*}{ Chloride } & (gage) & 296.8 & 268.6 & 282.7 & 158 & 135 & 146.5 & 435.2 & 181 & 308.1 & 224 & 174.8 & 199.4 \\
\hline & (bucket) & 290 & 277.4 & 283.7 & 143.1 & 134.5 & 138.8 & 425.2 & 183.1 & 304.2 & 216.8 & 175.6 & 196.2 \\
\hline \multirow{2}{*}{$\begin{array}{r}\text { Nitrate, as } \\
\text { nitrogen }\end{array}$} & (gage) & 70.36 & 74.10 & 72.23 & 75.32 & 82.75 & 79.04 & 49.10 & 15.58 & 32.34 & 58.01 & 45.06 & 51.54 \\
\hline & (bucket) & 67.46 & 73.91 & 70.68 & 71.31 & 83.48 & 77.40 & 48.07 & 16.01 & 32.04 & 54.97 & 42.29 & 48.63 \\
\hline \multirow{2}{*}{$\begin{array}{l}\text { Ammonium, as } \\
\text { nitrogen }\end{array}$} & (gage) & 34.20 & 28.15 & 31.18 & 25.71 & 41.50 & 33.60 & 16.24 & 7.47 & 11.86 & 21.44 & 12.37 & 16.90 \\
\hline & (bucket) & 32.76 & 28.44 & 30.60 & 24.72 & 42.22 & 33.47 & 16.10 & 7.66 & 11.88 & 20.95 & 12.69 & 16.82 \\
\hline \multirow{2}{*}{$\begin{array}{l}\text { Orthophosphate } \\
\text { as phosphorus }\end{array}$} & (gage) & .45 & .60 & .52 & .25 & .39 & .32 & 2.10 & .60 & 1.35 & .58 & .25 & .42 \\
\hline & (bucket) & .44 & .70 & .57 & .23 & .39 & .31 & 2.22 & .60 & 1.41 & .57 & .24 & .40 \\
\hline
\end{tabular}

\footnotetext{
${ }^{1}$ Orthophosphate loads are less reliable estimates because a large number of samples with concentrations less than the detection limit were utilized.
} 
Table 16. Seasonal precipitation characteristics and constituent concentrations at the National Atmospheric Deposition Program site at Truro. Massachusetts, spring 1983 through winter 1985

[Gage: Concentrations based on volume of precipitation measured in the precipitation gage. Bucket: Concentrations based on volume of precipitation measured in the collection bucket. Avg., average. Spring 1983, March 23 to June 21, 1983; Summer 1983, June 22 to September 20, 1983 ; Autumn 1983, September 21 to December 20, 1983; Winter 1984, December 21, 1983 to March 20, 1984; Spring 1984, March 21 to June 19, 1984; Summer 1984, June 20 to September 18, 1984; Autum 1984, September 19 to December 18, 1984; Winter 1985, December 19, 1984 to March 19, 1985. $\mu$ S/cm, microsiemen per centimeter; ${ }^{\circ} \mathrm{C}$, degree Celsius; mm, millimeter]

\begin{tabular}{|c|c|c|c|c|c|c|c|c|c|c|c|c|c|}
\hline \multirow{3}{*}{\multicolumn{2}{|c|}{$\begin{array}{l}\text { Precipitation characteristic or } \\
\text { chemical constituent }\end{array}$}} & \multicolumn{12}{|c|}{ Volume-weighted mean (in milligrams per liter, except as noted) concentrations } \\
\hline & & \multicolumn{3}{|c|}{ Spring } & \multicolumn{3}{|c|}{ Summer } & \multicolumn{3}{|c|}{ Autumn } & \multicolumn{3}{|c|}{ Winter } \\
\hline & & 1983 & 1984 & Avg. & 1983 & 1984 & Avg. & 1983 & 1984 & Avg. & 1984 & 1985 & Avg. \\
\hline \multirow[t]{2}{*}{ Precipitation, in mm } & (gage) & 329 & 370 & 349 & 330 & 361 & 346 & 406 & 199 & 302 & 419 & 225 & 322 \\
\hline & (bucket) & 281 & 324 & 302 & 289 & 347 & 318 & 356 & 178 & 267 & 323 & 198 & 260 \\
\hline \multirow{2}{*}{$\begin{array}{l}\text { Specific conductance, } \\
\text { in } \mu S / \mathrm{cm} \text { at } 25^{\circ} \mathrm{C}\end{array}$} & (gage) & 27.1 & 29.1 & 28.2 & 28.2 & 28.4 & 28.3 & 26 & 29.4 & 26.8 & 25.9 & 34.2 & 28.5 \\
\hline & (bucket) & 27 & 29.4 & 28.3 & 28 & 28 & 28 & 25.9 & 28.8 & 26.6 & 25.3 & 34.4 & 28.5 \\
\hline \multirow[t]{2}{*}{$\mathrm{pH}$, in standard units } & (gage) & 4.47 & 4.46 & 4.47 & 4.31 & 4.55 & 4.45 & 4.54 & 4.84 & 4.60 & 4.57 & 4.40 & 4.51 \\
\hline & (bucket) & 4.48 & 4.46 & 4.47 & 4.31 & 4.55 & 4.46 & 4.54 & 4.84 & 4.60 & 4.57 & 4.40 & 4.50 \\
\hline \multirow[t]{2}{*}{ Hydrogen ions } & (gage) & .034 & .035 & .034 & .049 & .029 & .036 & .029 & .015 & .025 & .027 & .040 & .031 \\
\hline & (bucket) & .033 & .035 & .034 & .049 & .028 & .035 & .029 & .015 & .026 & .027 & .040 & .032 \\
\hline \multirow[t]{2}{*}{ Calcium } & (gage) & .17 & .12 & .14 & .13 & .08 & .09 & .12 & .15 & .12 & .14 & .14 & .14 \\
\hline & (bucket) & .17 & .12 & .14 & .12 & .08 & .09 & .11 & .15 & .12 & .14 & .14 & .14 \\
\hline \multirow[t]{2}{*}{ Magnesium } & (gage) & .226 & .134 & .177 & .168 & .077 & .108 & .266 & .395 & .299 & .287 & .313 & .295 \\
\hline & (bucket) & .232 & .134 & .179 & .167 & .077 & .107 & .264 & .386 & .295 & .275 & .315 & .289 \\
\hline \multirow[t]{2}{*}{ Sodium } & (gage) & 1.701 & .969 & 1.308 & 1.289 & .526 & .784 & 2.172 & 3.168 & 2.424 & 2.428 & 2.567 & 2.472 \\
\hline & (bucket) & 1.754 & .970 & 1.331 & 1.292 & .528 & .778 & 2.153 & 3.093 & 2.395 & 2.333 & 2.585 & 2.421 \\
\hline \multirow[t]{2}{*}{ Potassium } & (gage) & .078 & .050 & .063 & .062 & .029 & .040 & .090 & .131 & .100 & .097 & .108 & .101 \\
\hline & (bucket) & .079 & .050 & .063 & .062 & .029 & .040 & .089 & .128 & .099 & .094 & .109 & .099 \\
\hline \multirow[t]{2}{*}{ Sulfate } & (gage) & 1.83 & 1.59 & 1.70 & 2.09 & 1.32 & 1.58 & 1.58 & 1.31 & 1.51 & 1.48 & 1.96 & 1.64 \\
\hline & (bucket) & 1.81 & 1.58 & 1.68 & 2.09 & 1.30 & 1.56 & 1.57 & 1.30 & 1.50 & 1.47 & 1.96 & 1.65 \\
\hline \multirow[t]{2}{*}{ Chloride } & (gage) & 3.10 & 1.77 & 2.38 & 2.57 & .94 & 1.49 & 3.99 & 5.89 & 4.47 & 4.56 & 4.64 & 4.58 \\
\hline & (bucket) & 3.21 & 1.77 & 2.43 & 2.54 & .94 & 1.47 & 3.95 & 5.75 & 4.42 & 4.40 & 4.67 & 4.49 \\
\hline \multirow[t]{2}{*}{ Nitrate, as nitrogen } & (gage) & .20 & .18 & .19 & .26 & .17 & .20 & .16 & $\because .10$ & .14 & .15 & .24 & .18 \\
\hline & (bucket) & .20 & .18 & .19 & .26 & .17 & .20 & .16 & .10 & .14 & .14 & .25 & .18 \\
\hline \multirow{2}{*}{$\begin{array}{l}\text { Ammonium, as nitro- } \\
\text { gen }\end{array}$} & (gage) & .09 & .14 & .12 & .08 & .08 & .08 & .05 & .02 & .04 & .06 & .09 & .07 \\
\hline & (bucket) & .09 & .14 & .12 & .08 & .08 & .08 & .05 & .02 & .05 & .06 & .09 & .07 \\
\hline \multirow{2}{*}{$\begin{array}{l}\text { Orthophosphate }{ }^{1} \text {, as } \\
\text { phosphorus }\end{array}$} & (gage) & .001 & .005 & .003 & .001 & .002 & .002 & .002 & .002 & .002 & .002 & .002 & .002 \\
\hline & (bucket) & .002 & .005 & .003 & .002 & .002 & .002 & .002 & .002 & .002 & .002 & .002 & .002 \\
\hline
\end{tabular}

${ }^{1}$ Orthophosphate concentrations are less reliable estimates because a large number of samples with concentrations less than the detection limit were utilized. 
Table 17. Seasonal constituent loads in precipitation at the National Atmospheric Deposition Program site at Truro, Massachusetts, spring 1983 through winter 1985

[Gage: Loads based on volume of precipitation measured in the precipitation gage. Bucket: Loads based on volume of precipitation measured in the collection bucket. Avg., average. Spring 1983, March 23 to June 21, 1983; Summer 1983, June 22 to September 20, 1983; Autumn 1983, September 21 to December 20 ,

1983; Winter 1984, December 21, 1983 to March 20, 1984; Spring 1984, March 21 to June 19, 1984; Summer 1984, June 20 to September 18, 1984; Autumn 1984, September 19 to December 18, 1984; Winter 1985, December 19, 1984 to March 19, 1985]

\begin{tabular}{|c|c|c|c|c|c|c|c|c|c|c|c|c|c|}
\hline \multirow{2}{*}{\multicolumn{2}{|c|}{ Chemical constituent }} & \multicolumn{12}{|c|}{ Loads (milligrams per square meter) } \\
\hline & & \multicolumn{3}{|c|}{ Spring } & \multicolumn{3}{|c|}{ Summer } & \multicolumn{3}{|c|}{ Autumn } & \multicolumn{3}{|c|}{ Winter } \\
\hline & & 1983 & 1984 & Avg. & 1983 & 1984 & Avg. & 1983 & 1984 & Avg. & 1984 & 1985 & Avg. \\
\hline \multirow[t]{2}{*}{ Hydrogen ions } & (gage) & 11.19 & 12.83 & 12.01 & 16.28 & $10 . \overline{31}$ & 13.30 & 11.84 & 2.91 & 7.38 & 11.47 & 9.04 & 10.26 \\
\hline & (bucket) & 9.31 & 11.18 & 10.24 & 14.21 & 9.82 & 12.02 & 10.45 & 2.60 & 6.52 & 8.86 & 7.96 & 8.41 \\
\hline \multirow[t]{2}{*}{ Calcium } & (gage) & 56.39 & 43.04 & 49.72 & 41.55 & 27.91 & 34.73 & 46.62 & 30.51 & 38.56 & 58.76 & 30.86 & 44.81 \\
\hline & (bucket) & 47.40 & 37.42 & 42.41 & 35.49 & 26.28 & 30.88 & 40.32 & 26.73 & 33.52 & 44.26 & 27.04 & 35.65 \\
\hline \multirow[t]{2}{*}{ Magnesium } & (gage) & 74.24 & 49.67 & 61.96 & 55.42 & 27.85 & 41.64 & 108.20 & 78.43 & 93.32 & 120.20 & 70.36 & 95.28 \\
\hline & (bucket) & 65.13 & 43.41 & 54.27 & 48.36 & 26.77 & 37.56 & 94.04 & 68.44 & 81.24 & 88.85 & 62.31 & 75.58 \\
\hline \multirow[t]{2}{*}{ Sodium } & (gage) & 559.4 & 358.4 & 458.9 & 426.1 & 189.6 & 307.9 & 882.7 & 629.1 & 755.9 & 1,017 & 577.6 & 797.5 \\
\hline & (bucket) & 493.3 & 313.9 & 403.6 & 373.2 & 183.1 & 278.2 & 767.4 & 549 & 658.2 & 754.2 & 511.8 & 633 \\
\hline \multirow[t]{2}{*}{ Potassium } & (gage) & 25.54 & 18.65 & 22.10 & 20.44 & 10.49 & 15.46 & 36.51 & 25.96 & 31.24 & 40.79 & 24.26 & 32.52 \\
\hline & (bucket) & 22.19 & 16.25 & 19.22 & 17.77 & 10.09 & 13.93 & 31.71 & 22.79 & 27.25 & 30.36 & 21.61 & 25.98 \\
\hline \multirow[t]{2}{*}{ Sulfate } & (gage) & 603 & 587.2 & 595.1 & 690.9 & 474.1 & 582.5 & 641.1 & 261 & 451 & 622.4 & 441.5 & 531.9 \\
\hline & (bucket) & 509.2 & $510: 3$ & 509.8 & 602.6 & 452.1 & 527.4 & 561.1 & 230 & 395.5 & 476.3 & 388.9 & 432.6 \\
\hline \multirow[t]{2}{*}{ Chloride } & (gage) & 1,021 & 653.2 & 837.1 & 849.9 & 337.8 & 593.9 & 1,621 & 1,170 & 1,395 & 1,910 & 1,043 & 1,477 \\
\hline & (bucket) & 902.6 & 572.2 & 737.4 & 734.3 & 327.6 & 531 & 1,409 & 1,021 & 1,215 & 1,422 & 924.3 & 1,173 \\
\hline \multirow{2}{*}{$\begin{array}{r}\text { Nitrate, as } \\
\text { nitrogen }\end{array}$} & (gage) & 66.64 & 66.62 & 66.63 & 86.98 & 61.95 & 74.46 & 63.74 & 20.08 & 41.91 & 61.95 & 54.66 & 58.30 \\
\hline & (bucket) & 55.44 & 58.27 & 56.86 & 75.44 & 58.51 & 66.98 & 55.87 & 17.98 & 36.92 & 46.71 & 48.94 & 47.82 \\
\hline \multirow{2}{*}{$\begin{array}{l}\text { Ammonium, as } \\
\text { nitrogen }\end{array}$} & (gage) & 30.04 & 51.76 & 40.90 & 25.53 & 27.06 & 26.30 & 21.28 & 4.67 & 12.98 & 24.84 & 20.78 & 22.81 \\
\hline & (bucket) & 24.78 & 44.90 & 34.84 & 21.89 & 26.17 & 24.03 & 18.98 & 4.33 & 11.66 & 19.45 & 18.47 & 18.96 \\
\hline \multirow{2}{*}{$\begin{array}{l}\text { Orthophosphate } \\
\text { as phosphorus }\end{array}$} & (gage) & .49 & 1.68 & 1.08 & .50 & .55 & .52 & .82 & .39 & .60 & .91 & .43 & 0.67 \\
\hline & (bucket) & .42 & 1.51 & .96 & .43 & .53 & .48 & .74 & .37 & .56 & .70 & .34 & 0.52 \\
\hline
\end{tabular}

${ }^{1}$ Orthophosphate loads are less reliable estimates because a large number of samples with concentrations less than the detection limit were utilized. 
Table 18. Annual precipitation characteristics and consituent concentrations at three National Atmospheric Deposition Program sites in Massachusetts, spring 1983 through winter 1985

[Gage: Concentrations based on volume of precipitation measured in the precipitation gage. Bucket: Concentrations based on volume of precipitation measured in the collection bucket. $\mu \mathrm{S} / \mathrm{cm}$, microsiemen per centimeter; ${ }^{\circ} \mathrm{C}$, degree Celsius; $\mathrm{mm}$, millimeter]

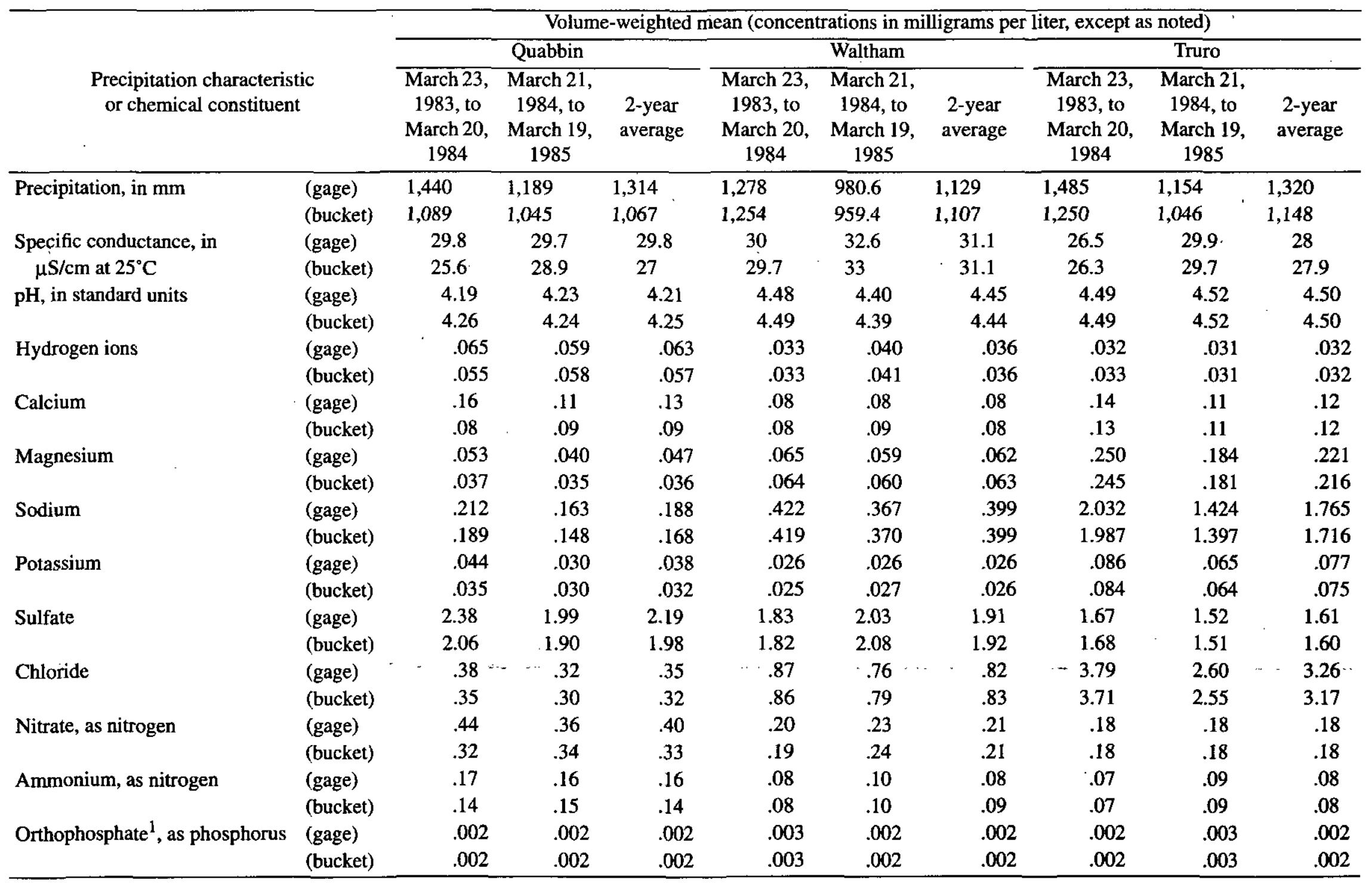

\footnotetext{
${ }^{1}$ Orthophosphate concentrations are less reliable estimates because a large number of samples with concentrations less than the detection limit were utilized.
} 
Table 19. Annual constituent loads in precipitation at three National Atmospheric Depostion Program sites in Massachusetts, spring 1983 through winter 1985

[Gage: Concentrations based on volume of precipitation measured in the precipitation gage. Bucket: Concentrations based on volume of precipitation measured in the collection bucket]

\begin{tabular}{|c|c|c|c|c|c|c|c|c|c|c|}
\hline \multirow{3}{*}{ Chemical constituent } & & \multicolumn{9}{|c|}{ Loads (milligrams per square meter) } \\
\hline & & \multicolumn{3}{|c|}{ Quabbin } & \multicolumn{3}{|c|}{ Waltham } & \multicolumn{3}{|c|}{ Truro } \\
\hline & & $\begin{array}{c}\text { March 23, } \\
1983, \text { to } \\
\text { March 20, } \\
1984\end{array}$ & $\begin{array}{c}\text { March 21, } \\
\text { 1984, to } \\
\text { March 19, } \\
1985\end{array}$ & $\begin{array}{c}\text { 2-year } \\
\text { average }\end{array}$ & $\begin{array}{c}\text { March 23, } \\
1983, \text { to } \\
\text { March 20, } \\
1984\end{array}$ & $\begin{array}{l}\text { March 21, } \\
\text { 1984, to } \\
\text { March 19, } \\
1985\end{array}$ & $\begin{array}{l}\text { 2-year } \\
\text { average }\end{array}$ & $\begin{array}{l}\text { March 23, } \\
1983 \text {, to } \\
\text { March 20, } \\
1984\end{array}$ & $\begin{array}{l}\text { March 21, } \\
1984, \text { to } \\
\text { March 19, } \\
1985\end{array}$ & $\begin{array}{c}\text { 2-year } \\
\text { average }\end{array}$ \\
\hline \multirow[t]{2}{*}{ Hydrogen ions } & (gage) & 93.21 & 70.65 & 81.93 & 42.34 & 39.37 & 40.86 & 48.21 & 35.54 & 41.88 \\
\hline & (bucket) & 60.19 & 60.99 & 60.59 & 41.11 & 39.37 & 40.24 & 40.82 & 32 & 36.41 \\
\hline \multirow[t]{2}{*}{ Calcium } & (gage) & 231.3 & 125.8 & 178.6 & 106.6 & 83.20 & 94.90 & 202.6 & 128.7 . & 165.6 \\
\hline & (bucket) & 90.37 & 92.64 & 91.50 & 102.4 & 85.36 & 93.86 & 167.1 & $114.3^{\circ}$ & 140.7 \\
\hline \multirow[t]{2}{*}{ Magnesium } & (gage) & 76.58 & 47.18 & 61.88 & 82.71 & 57.92 & 70.32 & 371.9 & 212.9 & 292.4 \\
\hline & (bucket) & 40.74 & 36.89 & 38.82 & 80.35 & 57.95 & 69.15 & 306.4 & 189.2 & 247.8 \\
\hline \multirow[t]{2}{*}{ Sodium } & (gage) & 305 & 194.1 & 249.6 & 539 & 359.6 & 449.3 & 3,017 & 1,644 & 2,330 \\
\hline & (bucket) & 206.2 & 154.5 & 180.3 & 525.1 & 355.2 & 440.2 & 2,483 & 1,461 & 1,972 \\
\hline \multirow[t]{2}{*}{ Potassium } & (gage) & 63.50 & 36.21 & 49.86 & 33.11 & 25.81 & 29.46 & 127.4 & 75.01 & 101.2 \\
\hline & (bucket) & 38.65 & 30.88 & 34.76 & 31.96 & 25.58 & 28.77 & 105 & 66.92 & 85.95 \\
\hline \multirow[t]{2}{*}{ Sulfate } & (gage) & 3,429 & 2,360 & 2,894 & 2,390 & 1,990 & 2,165 & 2,485 & 1,759 & 2,122 \\
\hline & (bucket) & 2,240 & 1,987 & 2,113 & 2,276 & 1,991 & 2,133 & 2,093 & 1,579 & 1,836 \\
\hline \multirow[t]{2}{*}{ Chloride } & (gage) & 554.9 & 374.7 & 464.8 & 1,113 & 744.3 & 928.6 & 5,626 & 2,996 & 4,311 \\
\hline & (bucket) & 377.9 & 309 & 343.5 & 1,074 & 757.5 & 915.9 & 4,632 & 2,663 & 3,648 \\
\hline \multirow[t]{2}{*}{ Nitrate, as nitrogen } & (gage) & 627.2 & 429.3 & 528.2 & 253.4 & 228.2 & 240.8 & 265.3 & 206 & 235.6 \\
\hline & (bucket) & 354.1 & 357.2 & 355.6 & 242.3 & 227.4 & 234.8 & 222.5 & 186.2 & 204.3 \\
\hline \multirow[t]{2}{*}{ Ammonium, as nitrogen } & (gage) & 239.3 & 184.3 & 211.8 & 97.87 & 93.56 & 95.72 & 98.41 & 105.2 & 101.8 \\
\hline & (bucket) & 148.3 & 157.1 & 152.7 & 94.76 & 95.65 & 95.20 & 82.91 & 95.02 & 88.96 \\
\hline \multirow[t]{2}{*}{ Orthophosphate $^{1}$, as phosphorus } & (gage) & 3.07 & 2.84 & 2.96 & 3.37 & 1.73 & 2.55 & 2.80 & 2.98 & 2.89 \\
\hline & (bucket) & 2.15 & 2.52 & 2.34 & 3.44 & 1.83 & 2.64 & 2.36 & 2.69 & 2.52 \\
\hline
\end{tabular}

\footnotetext{
${ }^{1}$ Orthophosphate loads are less reliable estimates because a large number of samples with concentrations less than the detection limit were utilized.
} 
This is because of an inverse relation between precipitation depth and concentration for some chemical constituents such as sulfate (figs. 9 and 10), particularly at an inland site not significantly affected by sea salt. For example, sulfate concentrations in precipitation at Quabbin (table 12) and Waltham (table 14) were at typical peak concentrations during both summers when power generation was highest and conversion of sulfur oxides to sulfuric acid in the atmosphere was the quickest because of warm air temperatures, increased hours of sunlight, and strong radiation from the sun. Between spring and summer 1984 at Quabbin, sulfate concentration in precipitation increased 80 percent (from 1.55 to $2.79 \mathrm{mg} / \mathrm{L}$ ); whereas, during the same period at Waltham, sulfate concentrations in precipitation increased 67 percent (from 1.75 to $2.92 \mathrm{mg} / \mathrm{L}$ ). However, between spring and summer 1984, sulfate loads in precipitation increased only 5 percent (from 734 to $772 \mathrm{mg} / \mathrm{m}^{2}$ ) at Quabbin and only 2 percent (from 697 to $711 \mathrm{mg} / \mathrm{m}^{2}$ ) at Waltham. Sulfate loads in precipitation in spring and summer are similar even though sulfate concentrations increased dramatically because precipitation depth decreased during the same period. Precipitation depth decreased 42 percent (from 474 to $277 \mathrm{~mm}$ ) at Quabbin and 39 percent (from 397 to $243 \mathrm{~mm}$ ) at Waltham.

The chemical composition of precipitation in Massachusetts is related to whether the site is inland or near the coast. In table 20 , concentrations of ammonium and nitrate are reported as $\mathrm{NH}_{4}$ and $\mathrm{NO}_{3}$, respectively, in microequivalents (already defined) of mean annual constituent loads to show the order of constituent dominance in precipitation at each site. However, in tables 12-19, concentrations of ammonium and nitrate are each reported as nitrogen in milligrams per liter to facilitate the addition of nitrogen species in precipitation. At both inland sites, hydrogen ion is the dominant cation and sulfate the dominant anion in precipitation; whereas at the coastal site, sodium is the dominant cation and chloride the dominant anion in precipitation. The dominance of hydrogen sulfate in precipitation is attributed to the burning of fossil fuels, and the dominance of sodium chloride in precipitation is attributed to aerosols from ocean water. These primary constituents reflect the overriding effect fossil fuels and ocean water have on precipitation quality at inland areas and along coastal areas, respectively. However, secondary constituents in precipitation, especially at inland sites, reflect local sources. For example, in precipitation at Quabbin, ammonium has the second highest cation concentration and nitrate has the second highest anion concentration; whereas in precipitation at Waltham, sodium has the second highest cation concentration and chloride has the second highest anion concentration. The higher concentration of ammonium in precipitation at Quabbin compared to that in precipitation at Waltham is thought to result from the decomposition of animal wastes generated by agricultural practices in the Connecticut River Valley of western Massachusetts and Connecticut and the application of fertilizers to farmland. In addition, the higher concentrations of nitrate in precipitation at Quabbin compared to Waltham may be partially attributed to fertilizers, but most of the nitrate in precipitation at both sites probably is from the burning of fossil fuels. At Waltham, the higher concentrations of sodium chloride in precipitation are attributed to oceanic sources rather than deicing chemicals applied to area roads. If deicing chemicals were the source, winter precipitation should have the highest concentrations, but highest concentrations are present in summer precipitation. The seasonal variation in sodium and chloride concentrations in precipitation also may be affected by the more effective removal of particulates from the atmosphere by rain than by snow.

Mean annual volume-weighted concentrations and loads (tables 18 and 19) indicate concentration and load gradients of certain constituents in precipitation across the State. Except for two constituents (potassium and sulfate), the concentration gradients were nearly identical to those for loads. Generally, precipitation depth did not change the gradient pattern.

Two possible explanations for the observed gradient patterns are (1) land-use characteristics of the surrounding area, such as rural/agricultural (Quabbin), urban/suburban (Waltham), or rural/coastal (Truro), or (2) directional orientation, such as west to east (Quabbin to Waltham to Truro) across Massachusetts, Quabbin being the farthest from the Atlantic Ocean. Data at these sites are sufficient to draw preliminary conclusions regarding general statewide patterns, but these data are insufficient to draw lines of equal concentrations or loads statewide. Trends observed for ten common constituents in precipitation are presented by constituent in the paragraphs that follow. The trends are inferred from data on overall-period averages listed in tables 18 and 19. 
Table 20. Mean annual constituent loads based on the volume of precipitation measured by the rain gage at the three National Atmospheric Deposition Program sites in Massachusetts, spring 1983 through winter 1985

[ $\mu \mathrm{eq} / \mathrm{m}^{2} / \mathrm{yr}$, microequivalent per square meter per year]

\begin{tabular}{|c|c|c|c|c|}
\hline \multirow{2}{*}{$\begin{array}{l}\text { Chemical } \\
\text { constituent }\end{array}$} & \multirow{2}{*}{$\begin{array}{l}\text { Cation or } \\
\text { anion }\end{array}$} & \multicolumn{3}{|c|}{ Mean annual load $\left(\mu \mathrm{eq} / \mathrm{m}^{2} / \mathrm{yr}\right)$} \\
\hline & & Quabbin & Waltham & Truro \\
\hline Hydrogen ions & Cation & 81.3 & 40.5 & 41.6 \\
\hline Calcium & Cation & 8.91 & 4.74 & 8.27 \\
\hline Magnesium & Cation & 5.09 & 5.79 & 24.10 \\
\hline Sodium & Cation & 10.9 & 19.5 & 101 \\
\hline Potassium & Cation & 1.28 & .75 & 2.59 \\
\hline Sulfate & Anion & 60.3 & 45.1 & 44.2 \\
\hline Chloride & Anion & $13: 1$ & 26.2 & 122 \\
\hline Nitrate & Anion & 37.7 & 17.2 & 16.8 \\
\hline Ammonium & Cation & 15.10 & 6.83 & 7.27 \\
\hline $\begin{array}{l}\text { Orthophosphate }{ }^{1} \text {, as } \\
\text { phosphorus }\end{array}$ & Anion & .09 & .08 & .09 \\
\hline
\end{tabular}

${ }^{1}$ Orthophosphate loads are less reliable estimates because a large number of samples with concentrations less than the detection limit were utilized.

Calcium.-No clear trend across the State can be described in terms of either concentration or load. However, concentrations and loads in precipitation at Quabbin, the rural/agricultural site, and at Truro, the rural/coastal site, were similar (concentrations, 0.13 and $0.12 \mathrm{mg} / \mathrm{L}$, respectively; loads, 179 and $166 \mathrm{mg} / \mathrm{m}^{2}$, respectively); whereas at Waltham, the urban/suburban site, concentration was about two-thirds $(0.08 \mathrm{mg} / \mathrm{L})$ and load was about one-half $\left(95 \mathrm{mg} / \mathrm{m}^{2}\right)$ those at Quabbin or Truro.

Magnesium.-At the inland sites, Quabbin and Waltham, concentrations and loads in precipitation were similar (concentrations, 0.05 and $0.06 \mathrm{mg} / \mathrm{L}$, respectively; loads, 62 and $70 \mathrm{mg} / \mathrm{m}^{2}$, respectively). At the coastal site, Truro, concentration and load in precipitation were much higher (concentration $0.22 \mathrm{mg} / \mathrm{L}$; load, $292 \mathrm{mg} / \mathrm{m}^{2}$ ).

Potassium. - At Quabbin and Waltham, concentrations in precipitation were about the same $(0.04$ and $0.03 \mathrm{mg} / \mathrm{L}$, respectively); at Truro, concentration in precipitation was twice those at the inland sites $(0.08 \mathrm{mg} / \mathrm{L})$. The load in precipitation at Quabbin was higher than that at Waltham $\left(50\right.$ and $29 \mathrm{mg} / \mathrm{m}^{2}$, respectively), but the highest load was at the coastal site, Truro $\left(101 \mathrm{mg} / \mathrm{m}^{2}\right)$.
Sodium.-Concentrations and loads in precipitation increased across the State from west to east towards the Atlantic Ocean. Sodium concentrations in precipitation increased from $0.19 \mathrm{mg} / \mathrm{L}$ at Quabbin to $0.40 \mathrm{mg} / \mathrm{L}$ at Waltham to a high of $1.76 \mathrm{mg} / \mathrm{L}$ at Truro on the coast. Loads in precipitation followed that same pattern with $250 \mathrm{mg} / \mathrm{m}^{2}$ at Quabbin, $449 \mathrm{mg} / \mathrm{m}^{2}$ at Waltham, and a high of $2,330 \mathrm{mg} / \mathrm{m}^{2}$ at Truro.

Chloride.-Concentrations and loads in precipitation followed a similar gradient pattern as for sodium, the site farthest from the ocean having the lowest concentration. Concentrations of chloride in precipitation increased from $0.35 \mathrm{mg} / \mathrm{L}$ at Quabbin to $0.82 \mathrm{mg} / \mathrm{L}$ at Waltham to a high of $3.26 \mathrm{mg} / \mathrm{L}$ at Truro on the coast. Similarly, loads in precipitation increased from $465 \mathrm{mg} / \mathrm{m}^{2}$ at Quabbin to $929 \mathrm{mg} / \mathrm{m}^{2}$ at Waltham to a high of $4,310 \mathrm{mg} / \mathrm{m}^{2}$ at Truro on the coast.

Orthophosphate phosphorus.-This is the only constituent that did not indicate any trend in concentrations or loads in precipitation across the State. Concentrations in precipitation at all three sites were estimated at $0.002 \mathrm{mg} / \mathrm{L}$, and loads in precipitation at all sites were estimated at $3 \mathrm{mg} / \mathrm{m}^{2}$. 
Ammonium.-The highest concentration $(0.16 \mathrm{mg} / \mathrm{L})$ was in precipitation at Quabbin, the rural/agricultural site; concentrations in precipitation were equal $(0.08 \mathrm{mg} / \mathrm{L})$ at Waltham, the urban/suburban site, and Truro, the rural/coastal site. Loads were highest in precipitation at Quabbin $\left(212 \mathrm{mg} / \mathrm{m}^{2}\right)$; whereas loads in precipitation at Waltham and Truro were about the same (96 and $102 \mathrm{mg} / \mathrm{m}^{2}$, respectively). The higher ammonium concentrations in precipitation in western Massachusetts are attributable to agricultural practices in the Connecticut River Valley.

Nitrate.-There is a pattern of decreasing nitrate concentration in precipitation from $0.40 \mathrm{mg} / \mathrm{L}$ at Quabbin, the rural/agricultural site, to $0.21 \mathrm{mg} / \mathrm{L}$ at Waltham, the urban/suburban site, to $0.18 \mathrm{mg} / \mathrm{L}$ at Truro, the rural/coastal site. However, loads in precipitation at Quabbin of $528 \mathrm{mg} / \mathrm{m}^{2}$ are far higher than those at either Waltham or Truro, which are about equal (241 and $236 \mathrm{mg} / \mathrm{m}^{2}$, respectively). The higher concentrations and loads in precipitation at Quabbin than at Waltham and Truro also may result from agricultural practices in western Massachusetts.

Sulfate. - The gradient for concentrations in precipitation is a gradual decline eastward across the State, from $2.19 \mathrm{mg} / \mathrm{L}$ at Quabbin to $1.91 \mathrm{mg} / \mathrm{L}$ at Waltham to $1.61 \mathrm{mg} / \mathrm{L}$ at Truro. However, loads in precipitation do not follow this concentration gradient completely. The sulfate load in precipitation is the highest at Quabbin $\left(2,890 \mathrm{mg} / \mathrm{m}^{2}\right)$, whereas the loads in precipitation at Waltham $\left(2,160 \mathrm{mg} / \mathrm{m}^{2}\right)$ and Truro $\left(2,120 \mathrm{mg} / \mathrm{m}^{2}\right)$ are about equal.

Hydrogen ion.-Concentration and load gradients are similar to those for nitrate and sulfate. Concentrations in precipitation are highest at Quabbin $(0.063 \mathrm{mg} / \mathrm{L})$, lower at Waltham $(0.036 \mathrm{mg} / \mathrm{L})$, and slightly lower at Truro $(0.032 \mathrm{mg} / \mathrm{L})$. Hydrogen loads in precipitation decrease from a high of $82 \mathrm{mg} / \mathrm{m}^{2}$ at Quabbin to virtually equal loads of $41 \mathrm{mg} / \mathrm{m}^{2}$ at Waltham and $42 \mathrm{mg} / \mathrm{m}^{2}$ at Truro.

Chloride, sodium, magnesium, and potassium (constituents primarily from oceanic sources) have highest concentrations and loads in precipitation at the coast and lower, similar concentrations and loads inland. Chloride, at a concentration of $19,000 \mathrm{mg} / \mathrm{L}$, and sodium, at a concentration of $10,500 \mathrm{mg} / \mathrm{L}$, rank first and second in concentration among the ionic components of seawater; magnesium, at a concentration of $1,350 \mathrm{mg} / \mathrm{L}$, ranks fourth. All three of these constituents in precipitation decrease in concentration from east to west across the State. The high concentrations of these constituents in seawater probably results in aerosols of these constituents being carried farther inland with storms before being washed out of the atmosphere or masked by other sources of these constituents. However, the results for calcium (another constituent from oceanic sources), which does not have a detectable concentration gradient pattern in precipitation across the State, and potassium, with no progressive decrease from high concentrations in precipitation on the coast, may result from the relatively small concentrations in seawater of both ions (410 and $390 \mathrm{mg} / \mathrm{L}$, respectively) as compared to chloride, sodium, and magnesium. Because of the low concentrations of calcium and potassium in seawater, small inland sources can alter the concentration gradient in precipitation from the ocean to the inland sites.

Concentrations and loads of ions associated with acid precipitation (nitrate, sulfate, and hydrogen) are much higher in western Massachusetts than in eastern Massachusetts. Gaseous oxides of nitrogen and sulfur discharged to the atmosphere from combustion of fossil fuels are converted to nitric and sulfuric acids in the atmosphere. Because hydrogen ion is a component from that formation, it is therefore consistent to find the highest concentration of hydrogen ion in precipitation associated with the highest concentrations of nitrate and sulfate in precipitation. About twice the nitrate and hydrogen ion and 35 percent more sulfate are deposited in precipitation at Quabbin than at either Waltham or Truro; this relation indicates that the interior of Massachusetts receives more products of acid precipitation than do eastern and coastal areas of Massachusetts. Possibly, because of its greater distance from the ocean, Quabbin is more affected than Waltham or Truro by downwind industrial and agricultural sources of the acid-forming products. 


\section{SUMMARY AND CONCLUSIONS}

Water quality of precipitation of selected sites in Massachusetts was studied by the U.S. Geological Survey to determine (1) the relation between precipitation quality and storm type and (2) the loads of various chemical constituents from precipitation at selected locations in Massachusetts. The effects of three storm types (continental cyclone, oceanic cyclone, and cold front) on precipitation quality were studied by use of data from storms measured at a rural inland location, Princeton, Mass., and a rural coastal location, Truro, Mass., from September 1983 through April 1985. These storm types were selected because they yield most of the precipitation in Massachusetts. Annual and seasonal concentrations and loads of dissolved chemical constituents deposited in Massachusetts were estimated by use of data from all storms measured from March 1983 through April 1985 by the National Atmospheric Deposition Program at a rural inland location, Quabbin Reservoir, Mass.; a suburban inland location, Waltham, Mass.; and a rural coastal location, Truro, Mass.

Statistical analysis using the nonparametric (ranked-mean) Kruskal-Wallis test indicated that storm types affected the concentrations of some chemical constituents in precipitation differently at Princeton (inland site) than at Truro (coastal site) but affected other chemical constituents in precipitation similarly at both sites. Even though various storm types affect certain constituent concentrations differently, those differences result more from the types of airmasses (continental or oceanic) that constitute the storm than from the type of the storm.

At the inland site (Princeton), statistical analysis indicated that ranked means of precipitation duration, precipitation depth, and specific conductance and concentrations of the two most common constituents (hydrogen and sulfate, which together equal 50 percent of all the constituents in precipitation on an equivalent basis) and three trace elements (aluminum, bromide, and copper) were related to storm type at the 5-percent significance level. No significant differences were detected among storm types for the other 18 storm characteristics and chemical constituents in precipitation examined in this study. No significant difference was detected between the ranked means of storm duration and precipitation depth for continental and oceanic cyclones; however, duration and depth of precipitation from cyclones were greater than for advancing cold fronts. Median values generated from reconversion of the ranked means indicate that cyclones produce about twice as much water and last about three times longer than do cold-front storms. Even though cold-front storms produced less precipitation, the precipitation contained more hydrogen ions and dissolved constituents than did precipitation from either type of cyclone, probably because cold fronts cross more land mass than do cyclones and receive more dust and by-products from the burning of fossil fuels. Precipitation from continental cyclones and cold fronts contained more sulfate than did oceanic cyclones, indicating that more sulfate is derived from continental airmasses than from oceanic airmasses. This finding probably is also related to the burning of fossil fuels on land.

In general, if storm types affected constituent concentrations in precipitation at Princeton, loads also were affected. Rank-mean loads were significantly different among storm types for only one common constituent (hydrogen ion) and two trace elements (bromide and copper). Even though precipitation depth was significantly higher for cyclones than for cold-front storms, nearly all the chemical constituents in precipitation except hydrogen ion, bromide, and copper, were deposited equally by each of the three storm types.

At the coastal site (Truro), differences in precipitation duration, precipitation depth, and concentrations and loads of chloride, sodium, calcium, magnesium, and potassium were significant with respect to storm type at the 5-percent significance level. At this site, both types of cyclones produced higher loads of sulfate and higher concentrations and loads of chloride, sodium, magnesium, and potassium than did cold-front storms. Continental cyclones yielded higher calcium concentrations and loads than did cold-front storms, whereas oceanic cyclones yielded calcium concentrations and loads between those for the other two storm types. These results probably indicate the effects of ocean aerosols because of the close proximity of the site to the Atlantic Ocean $(1.6 \mathrm{~km})$ on the east side and to Cape Cod Bay $(4.5 \mathrm{~km})$ on the west side.

Oceanic effects on precipitation quality are indicated from comparison of microequivalents of the common chemical constituents at Princeton and Truro. For example, the sum of the microequivalents for the major cations and anions in precipitation equals 446 $\mu$ eq/ $\mathrm{L}$ at Truro which is $1.5 \mathrm{~km}$ from the ocean, and 106 $\mu \mathrm{eq} / \mathrm{L}$ at Princeton, which is $120 \mathrm{~km}$ from the 
Connecticut coast and $72 \mathrm{~km}$ from Boston Harbor. Principal ions in precipitation at Truro were sodium and chloride, which constitute 70 percent of the microequivalents among all constituents; whereas, principal ions in precipitation at Princeton were hydrogen ion and sulfate, which constitute 50 percent of all constituents. Considering major cations and anions, precipitation at Truro contains about 14 times the sodium, 9 times the chloride and magnesium, and 2 times the calcium, potassium, and sulfate measured in precipitation at Princeton. Precipitation at the Truro coastal site contained only slightly less hydrogen, nitrate, and ammonium ions than precipitation at Princeton. Analysis of sea-salt contributions to precipitation quality indicated that more than 90 percent of the chloride, sodium, and magnesium; 86 percent of the potassium; and 72 percent of the calcium in precipitation at Truro came from oceanic sources; whereas, at Princeton, this analysis yielded considerably smaller percentages from oceanic sources (from 6 to 67 percent, with an average of about 31 percent). In addition, this analysis showed that, at Truro and Princeton, oceanic sulfate constituted 46 and 6 percent, respectively, of the total sulfate concentrations in precipitation at the two sites. Substraction of oceanic sulfate from the overall sulfate concentrations indicated that precipitation at Truro and Princeton contained about the same concentration $(1.04$ and $1.11 \mathrm{mg} / \mathrm{L}$, respectively) of non-oceanic sulfate, derived primarily from the burning of fossil fuels.

Concentrations of several trace elements in precipitation were studied at Princeton and at Truro, and the same general findings apply to both sites. Aluminum, barium, bromide, copper, iron, lead, manganese, strontium, and zinc were detected at low concentrations in numerous precipitation samples; antimony, arsenic, beryllium, boron, cadmium, chromium, cobalt, lithium, molybdenum, nickel, selenium, and vanadium were detected in precipitation samples at concentrations at or very near the detection limit for the chemical analysis used by the laboratory.

Data from the National Atmospheric Deposition Program were used to determine concentrations and loads for ammonium, calcium, chloride, hydrogen ion, magnesium, nitrate, orthophosphate phosphorus, potassium, sodium, and sulfate as well as to measure specific conductance in precipitation on an annual and seasonal basis from spring 1983 through winter 1985 at three sites (Quabbin, Waltham, and Truro) in
Massachusetts. Analysis of annual loads indicates an east-west gradient across the State for some constituents in precipitation but not for others. No trends in orthophosphate phosphorus and calcium in precipitation were found across the State with respect to concentrations and loads. Magnesium, potassium, sodium, and chloride concentrations and loads in precipitation were highest in samples from the coast and much lower in samples from inland locations, with little difference between Waltham and Quabbin. The dominance of these constituents at the coast (Truro) is a result of entrainment of sea salt in the precipitation. Loads of ammonium, nitrate, sulfate, and hydrogen in precipitation were highest at Quabbin and were about equal at Waltham and Truro, which is the reverse of the trends for the previously discussed constituents. The higher ammonium load in precipitation at Quabbin than that for the urban/suburban area of Waltham or the coastal area of Truro probably is the result of fertilizer use and decaying organic matter in the agricultural community in the Connecticut River Valley not far from Quabbin. Higher nitrate load in precipitation at Quabbin also is attributed to fertilizer use and to the burning of fossil fuels, which is the cause of the high concentrations of sulfate and hydrogen in precipitation. About twice as much nitrate and hydrogen and about 35 percent more sulfate are deposited in precipitation at Quabbin than at either Waltham or Truro; this pattern indicates that the interior of Massachusetts receives more products of acid precipitation than do eastern or coastal areas of Massachusetts. Possibly, Quabbin receives more air from downwind land sources that emit higher concentrations of these acid-forming products than oceanic air, which more commonly flows over eastern Massachusetts.

Storm data at Princeton and Truro and the weekly composite data at Quabbin, Waltham, and Truro indicate that oceanic effects on precipitation quality are strong at the coast but decrease rapidly with distance inland. Further, anthropogenic effects on precipitation quality are significant for nitrate and hydrogen ions at inland sites (Princeton and Quabbin) and for sulfate ions at all study sites. The relatively high concentrations and loads of hydrogen ion, nitrate, and anthropogenic sulfate measured in this study indicate that much of Massachusetts was receiving acid precipitation during the study (March 1983 through April 1985). 


\section{REFERENCES CITED}

Bras, R.L., 1990, Hydrology-an introduction to hydrological science: Reading, Mass., Addison-Wesley Publishing Company, $643 \mathrm{p}$.

Cogbill, C.V., and Likens, G.E., 1974, Acid precipitation in the northeastern United States: Water Resources Research, v. 10, no. 6, p. 1133-1137.

Conover, W.J., 1980, Practical nonparametric statistics, (2nd ed.): New York, John Wiley and Sons, 493 p.

Cowling, E.B., 1982, Acid precipitation in historical perspective: Environmental Science and Technology, v. 16, no. 2, p. 110A-123A.

Galloway, J.N., and Whelpdale, D.M., 1980, An atmospheric sulfur budget for eastern North America: Atmospheric Environment, v. 14, p. 409-417.

Gambell, A.W., and Fisher, D.W., 1966, Chemical composition of rainfall, eastern North Carolina and southeastern Virginia: U.S. Geological Survey Water-Supply Paper 1535-K, $41 \mathrm{p}$.

Gilbert, R.O., 1987, Statistical methods for environmental pollution modeling: New York, Van Nostrand Reinhold, $320 \mathrm{p}$.

Glass, N.R., Arnold, D.E., Galloway, J.N., Hendrey, G.R., Lee, J.J., McFee, W.W., Norton, S.A., Powers, C.F., Rambo, D.L., and Schofield, C.L., 1982, Effects of acid precipitation: Environmental Science and Technology, v. 16 , no. 3 , p. $162 \mathrm{~A}-169 \mathrm{~A}$.

Granat, L., 1972, On the relation between $\mathrm{pH}$ and the chemical composition in atmospheric precipitation: Tellus, v. 24 , no. 6, p. $550-560$.

Haagenson, P.L., Lazrus, A.L., Kuo, Y.H., and Caldwell, G.A., 1985, A relationship between acid precipitation and three-dimensional transport associated with synoptic-scale cyclones: Journal of Climate and Applied Meteorology, v. 24, p. 967-976.

Hem, J.D., 1985, Study and interpretation of chemical characteristics of natural water, (3d ed.): U.S. Geological Survey Water-Supply Paper 2254, $263 \mathrm{p}$.

Hendry, C.D., Berish, C.W., and Edgerton, E.S., 1984, Precipitation chemistry at Turrialba, Costa Rica: Water Resources Research, v. 20, no. 11, p. 1677-1684.

Kennedy, V.C., Zellweger, G.W., and Avanzino, R.J., 1979, Variation of rain chemistry during storms at two sites in northern California: Water Resources Research, v. 15, no. 3, p. 687-702.

Likens, G.E., Wright, R.F., Galloway, J.N., and Butler, T.J., 1979, Acid rain: Scientific American, v. 241, no. 4, p. 43-51.
Munger, W.J., and Eisenreich, S.J., 1983, Continental-scale variations in precipitation chemistry: Environmental Science and Technology, v. 17,no: 1, p. 32A-42A.

Paciga, J.J., and Jervis, R.E., 1976, Multielement size characterization of urban aerosols: Environmental Science and Technology, v. 10, no. 12, p. 1124-1128.

Pearson, F.J., Jr., and Fisher, D.W., 1971, Chemical composition of atmospheric precipitation in the northeastern United States: U.S. Geological Survey Water-Supply Paper 1535-P, 23 p.

Raynor, G.S., and Hayes, J.V., 1982, Variation in chemical wet deposition with meteorological conditions: Atmospheric Environment, v. 16, no. 7, p. 1647-1656.

Semonin, R., and Volchok, H., 1978, Field observer instruction manual: Fort Collins, Colo., Natural Resource Ecology Laboratory, Colorado State University, National Atmospheric Deposition Program, North Central Regional Project NC-141, 34 p.

Semonin, R., and Volchok, H., 1979, Site selection and certification: Fort Collins, Colo., Natural Resource Ecology Laboratory, Colorado State University, National Atmospheric Deposition Program, North Central Regional Project NC-141, $11 \mathrm{p}$.

Turk, J.T., 1983, An evaluation of trends in the acidity of precipitation and the related acidification of surface water in North America: U.S. Geological Survey WaterSupply Paper 2249, 18 p.

Walker, J., 1985, The amateur scientist: Scientific American, v. 252 , no. 1 , p. 112-119.

Ward, R.C., Loftis, J.C., and McBride, G.B., 1990, Design of water quality monitoring systems: New York, Van Nostrand Reinhold, 231 p.

Wedberg, G.H., Chan, K.C., and Cohen, B.L., 1974, X-ray fluorescence study of atmospheric particulates in Pittsburgh: Environmental Science and Technology, v. 8, no. 13, p. 1090-1093.

Willey, J.D., Bennett, R.I., Williams, J.M., Denne, R.K., Kornegay, C.R., Perlotto, M.S., and Moore, B.M., 1988, Effect of storm type on rainwater composition in southeastern North Carolina: Environmental Science and Technology, v. 22, no. 1, p. 41-46.

Wolff, G.T., Lioy, P.J., Golub, H., and Hawkins, J.S., 1979, Acid precipitation in the New York metropolitan areaits relationship to meteorological factors: Environmental Science and Technology, v. 13, no. 2, p. 209-212. 
TABLES 21-22 
Table 21. Physical data and chemical-constituent concentrations for storm-precipitation samples collected at Princeton. Massachusetts, September 1983 through April 1985

[Collection site was located at the Massachusetts Audubon Society's Wachusett Meadow Wildlife Sanctuary, latitude $42^{\circ} 27^{\prime} 23^{\prime \prime}$, longitude $71^{\circ} 54^{\prime} 23^{\prime \prime}$. Storm type: CC, continental cyclone; CF, cold front; OC, oceanic cyclone; ND, storm type not determined. $\mathrm{N}$, nitrogen; $\mathrm{P}$, phosphorus; $\mathrm{mm}$, millimeter; $\mathrm{h}$, hour; $\mu \mathrm{S} / \mathrm{cm}$, microsiemen per centimeter at 25 degrees Celsius; $\mathrm{mg} / \mathrm{L}$, milligram per liter; $\mu \mathrm{g} / \mathrm{L}$, microgram per liter; --, not measured; <, actual value is less than the detection limit for the constituent concentration]

\begin{tabular}{|c|c|c|c|c|c|c|c|c|c|c|}
\hline Date & $\begin{array}{l}\text { Storm } \\
\text { start } \\
\text { time } \\
\text { (h) }\end{array}$ & $\begin{array}{l}\text { Precip- } \\
\text { itation, } \\
\text { total } \\
(\mathrm{mm})\end{array}$ & $\begin{array}{l}\text { Storm } \\
\text { dura- } \\
\text { tion } \\
\text { (h) }\end{array}$ & $\begin{array}{l}\text { Storm } \\
\text { type }\end{array}$ & $\begin{array}{c}\text { Spe- } \\
\text { cific } \\
\text { conduct- } \\
\text { ance } \\
(\mu \mathrm{S} / \mathrm{cm})\end{array}$ & $\begin{array}{l}\mathrm{pH} \\
\text { (stand- } \\
\text { ard } \\
\text { units) }\end{array}$ & $\begin{array}{l}\text { Nitrogen, } \\
\text { ammonia, } \\
\text { dissolved } \\
\text { (mg/L } \\
\text { as } \mathrm{N})\end{array}$ & $\begin{array}{l}\text { Nitrogen, } \\
\text { nitrate, } \\
\text { dissolved } \\
\text { (mg/L } \\
\text { as } \mathrm{N})\end{array}$ & $\begin{array}{l}\text { Phos- } \\
\text { phorus, } \\
\text { dissolved } \\
\text { (mg/L } \\
\text { as P) }\end{array}$ & $\begin{array}{l}\text { Phos- } \\
\text { phorus, } \\
\text { ortho, } \\
\text { dissolved } \\
\text { (mg/L } \\
\text { as P) }\end{array}$ \\
\hline SEPT 1983 & & & & & & & & & & \\
\hline $\begin{array}{l}16-17 \\
21-22\end{array}$ & $\begin{array}{l}2300 \\
2100\end{array}$ & $\begin{array}{l}6.10 \\
24.1\end{array}$ & $\begin{array}{r}23 \\
9\end{array}$ & $\begin{array}{l}\mathrm{CC} \\
\mathrm{CF}\end{array}$ & $\begin{array}{r}37 \\
4\end{array}$ & $\begin{array}{l}4.70 \\
5.00\end{array}$ & $\begin{array}{l}0.241 \\
--\end{array}$ & $\begin{array}{l}0.700 \\
<.050\end{array}$ & -- & $\begin{array}{r}<0.060 \\
<.060\end{array}$ \\
\hline $\begin{array}{l}\text { SEPT 30- } \\
\text { OCT } 02\end{array}$ & 1900 & 76.5 & 36 & $\mathrm{OC}$ & 8 & 4.80 & -- & .090 & -- & $<.060$ \\
\hline $\begin{array}{l}\text { OCT } \\
23-24\end{array}$ & 1400 & 32.8 & 24 & $\mathrm{OC}$ & 4 & 4.90 & .030 & .080 & 0.002 & .010 \\
\hline $\begin{array}{l}\text { NOV } \\
10-11 \\
15-16 \\
21-21 \\
24-25 \\
28-29\end{array}$ & $\begin{array}{l}1700 \\
1900 \\
0300 \\
0100 \\
0800\end{array}$ & $\begin{array}{l}30.5 \\
68.6 \\
10.7 \\
65.8 \\
25.7\end{array}$ & $\begin{array}{r}23 \\
23 \\
6 \\
41 \\
29\end{array}$ & $\begin{array}{l}\text { OC } \\
\text { OC } \\
\text { CF } \\
\text { OC } \\
\text { CC }\end{array}$ & $\begin{array}{r}10 \\
7 \\
12 \\
7 \\
16\end{array}$ & $\begin{array}{l}4.50 \\
4.80 \\
4.60 \\
4.90 \\
4.50\end{array}$ & $\begin{array}{l}.130 \\
.080 \\
.080 \\
.060 \\
.030\end{array}$ & $\begin{array}{l}.230 \\
.070 \\
.160 \\
.080 \\
.130\end{array}$ & $\begin{array}{l}.002 \\
.009 \\
.002 \\
.006 \\
.002\end{array}$ & $\begin{array}{r}.004 \\
.003 \\
.008 \\
<.001 \\
<.001\end{array}$ \\
\hline $\begin{array}{l}\text { DEC } \\
06-07 \\
10-10 \\
12-14 \\
22-22 \\
28-28\end{array}$ & $\begin{array}{l}0700 \\
0100 \\
0700 \\
0500 \\
1700\end{array}$ & $\begin{array}{c}19.6 \\
2.29 \\
51.3 \\
15.2 \\
16.5\end{array}$ & $\begin{array}{r}30 \\
5 \\
50 \\
18 \\
7\end{array}$ & $\begin{array}{l}\text { CC } \\
\text { CF } \\
\text { ND } \\
\text { CC } \\
\text { CC }\end{array}$ & $\begin{array}{r}22 \\
48 \\
18 \\
7 \\
10\end{array}$ & $\begin{array}{l}4.20 \\
4.00 \\
4.50 \\
4.90 \\
4.70\end{array}$ & $\begin{array}{c}.030 \\
-- \\
.020 \\
-- \\
.030\end{array}$ & $\begin{array}{c}.020 \\
-- \\
.110 \\
-- \\
.730\end{array}$ & $\begin{array}{c}.003 \\
-- \\
.006 \\
-- \\
.013\end{array}$ & $\begin{array}{l}.004 \\
--.004 \\
-- \\
\quad .005\end{array}$ \\
\hline $\begin{array}{c}\text { JAN } 1984 \\
18-19 \\
24-24 \\
30-31\end{array}$ & $\begin{array}{l}1400 \\
0600 \\
1800\end{array}$ & $\begin{array}{c}6.86 \\
15.7 \\
5.84\end{array}$ & $\begin{array}{l}18 \\
14 \\
15\end{array}$ & $\begin{array}{l}\text { OC } \\
\text { ND } \\
\text { OC }\end{array}$ & $\begin{array}{l}25 \\
17 \\
21\end{array}$ & $\begin{array}{l}4.20 \\
4.30 \\
4.30\end{array}$ & $\begin{array}{l}-- \\
.40 \\
.058\end{array}$ & $\begin{array}{l}-. \\
.240 \\
.620\end{array}$ & $\begin{array}{r}- \\
.184 \\
.011\end{array}$ & $\begin{array}{r}-- \\
<.001 \\
.002\end{array}$ \\
\hline $\begin{array}{l}\text { FEB } \\
11-11 \\
14-16 \\
24-24 \\
28-29\end{array}$ & $\begin{array}{l}0900 \\
2300 \\
0100 \\
0200\end{array}$ & $\begin{array}{c}5.84 \\
52.3 \\
22.4 \\
29.2\end{array}$ & $\begin{array}{l}10 \\
49 \\
15 \\
33\end{array}$ & $\begin{array}{l}\text { ND } \\
\text { ND } \\
\text { OC } \\
\text { CC }\end{array}$ & $\begin{array}{r}28 \\
9 \\
9 \\
6\end{array}$ & $\begin{array}{l}4.20 \\
4.80 \\
4.60 \\
4.90\end{array}$ & $\begin{array}{r}-- \\
<.010 \\
.090 \\
.230\end{array}$ & $\begin{array}{r}.100 \\
.130 \\
.080\end{array}$ & $\begin{array}{r}-- \\
<.001 \\
.004 \\
<.001\end{array}$ & $\begin{array}{l}-- \\
<.001 \\
<.001 \\
.015\end{array}$ \\
\hline $\begin{array}{r}\text { MAR } \\
05-06 \\
13-14 \\
21-21 \\
29-30\end{array}$ & $\begin{array}{l}1200 \\
0700 \\
1600 \\
0000\end{array}$ & $\begin{array}{c}10.7 \\
35.8 \\
7.87 \\
39.4\end{array}$ & $\begin{array}{r}24 \\
24 \\
5 \\
39\end{array}$ & $\begin{array}{l}\text { CC } \\
\text { OC } \\
\text { CC } \\
\text { OC }\end{array}$ & $\begin{array}{r}14 \\
5 \\
14 \\
4\end{array}$ & $\begin{array}{l}4.20 \\
5.00 \\
4.50 \\
5.00\end{array}$ & $\begin{array}{l}-- \\
-- \\
.070 \\
.30\end{array}$ & $\begin{array}{l}-- \\
-- \\
.140 \\
.290\end{array}$ & $\begin{array}{l}-- \\
-- \\
-- \\
<.001\end{array}$ & $\begin{array}{l}-- \\
-- \\
<.060 \\
.016\end{array}$ \\
\hline $\begin{array}{l}\text { APR } \\
04-05 \\
14-16 \\
20-20 \\
23-25\end{array}$ & $\begin{array}{l}2000 \\
0300 \\
0500 \\
1600\end{array}$ & $\begin{array}{c}56.6 \\
23.1 \\
1.52 \\
15.5\end{array}$ & $\begin{array}{l}26 \\
67 \\
13 \\
49\end{array}$ & $\begin{array}{l}C C \\
C C \\
\text { OC } \\
\text { OC }\end{array}$ & $\begin{array}{l}18 \\
26 \\
99 \\
11\end{array}$ & $\begin{array}{l}4.47 \\
4.30 \\
3.70 \\
4.60\end{array}$ & $\begin{array}{r}.270 \\
.120 \\
-- \\
.040\end{array}$ & $\begin{array}{r}.150 \\
.320 \\
-- \\
.160\end{array}$ & $\begin{array}{l}.001 \\
-- \\
-- \\
.001\end{array}$ & $\begin{array}{r}.003 \\
<.060 \\
-- \\
.006\end{array}$ \\
\hline
\end{tabular}


Table 21. Physical data and chemical-constituent concentrations for storm-precipitation samples collected at Princeton, Massachusetts, September 1983 through April 1985--Continued

\begin{tabular}{|c|c|c|c|c|c|c|c|c|c|c|}
\hline Date & $\begin{array}{c}\text { Storm } \\
\text { start } \\
\text { time } \\
\text { (h) }\end{array}$ & $\begin{array}{c}\text { Precip- } \\
\text { itation, } \\
\text { total } \\
(\mathrm{mm})\end{array}$ & $\begin{array}{c}\text { Storm } \\
\text { dura- } \\
\text { tion } \\
\text { (h) }\end{array}$ & $\begin{array}{l}\text { Storm } \\
\text { type }\end{array}$ & $\begin{array}{c}\text { Spe- } \\
\text { cific } \\
\text { conduct- } \\
\text { ance } \\
(\mu \mathrm{S} / \mathrm{cm})\end{array}$ & $\begin{array}{c}\text { pH } \\
\text { (stand- } \\
\text { ard } \\
\text { units) }\end{array}$ & $\begin{array}{l}\text { Nitrogen, } \\
\text { ammonia, } \\
\text { dissolved } \\
\text { (mg/L } \\
\text { as } N \text { ) }\end{array}$ & $\begin{array}{l}\text { Nitrogen, } \\
\text { nitrate, } \\
\text { dissolved } \\
(\mathrm{mg} / \mathrm{L} \\
\text { as } \mathrm{N})\end{array}$ & $\begin{array}{l}\text { Phos- } \\
\text { phorus, } \\
\text { dissolved } \\
\text { (mg/L } \\
\text { as P) }\end{array}$ & $\begin{array}{l}\text { Phos- } \\
\text { phorus, } \\
\text { ortho, } \\
\text { dissolved } \\
\text { (mg/L } \\
\text { as P) }\end{array}$ \\
\hline \multicolumn{11}{|c|}{ MAY 1984} \\
\hline 03-05 & 1500 & 33.5 & 40 & OC & 24 & 4.33 & 0.490 & 0.300 & 0.003 & $<0.001$ \\
\hline 08-08 & 1000 & 13.7 & 13 & $\mathrm{CC}$ & 18 & 4.50 & .610 & .210 & $<.001$ & $<.001$ \\
\hline $23-23$ & 1600 & 12.4 & 5 & CF & 13 & 4.60 & .090 & .170 & .010 & $<.001$ \\
\hline $26-26$ & 1800 & 5.59 & 1 & CF & 43 & 4.00 & .365 & .590 & $<.001$ & $<.001$ \\
\hline $28-31$ & 1000 & 163 & 84 & $\mathrm{CC}$ & 8 & 4.74 & .010 & .100 & $<.001$ & $<.001$ \\
\hline \multicolumn{11}{|l|}{ JUNE } \\
\hline $01-02$ & 1700 & 35.6 & 24 & OC & 6 & 4.95 & $<.010$ & $<.050$ & .164 & .024 \\
\hline $14-14$ & 0700 & 1.52 & 10 & CF & 75 & 3.75 & - & -- & $\rightarrow$ & -- \\
\hline $18-19$ & 1400 & 5.08 & 15 & $\mathrm{CC}$ & 130 & 3.50 & .650 & 1.30 & - & -- \\
\hline $26-26$ & 1900 & 2.79 & 1 & ND & 14 & 4.50 & -- & -- & -- & -- \\
\hline $29-29$ & 0200 & 2.03 & 6 & CF & 34 & 4.08 & -- & -- & -- & -- \\
\hline \multicolumn{11}{|l|}{ JULY } \\
\hline $15-16$ & 1400 & 8.13 & 16 & $\mathrm{CF}$ & 99 & 3.80 & -- & -- & -- & -- \\
\hline $16-16$ & 1700 & 15.5 & 1 & $\mathrm{CF}$ & 39 & 4.18 & - & -- & -- & -- \\
\hline $18-18$ & 0900 & 13.0 & 7 & CF & 35 & 4.12 & -- & -- & - & -- \\
\hline $21-21$ & 1400 & 6.10 & 7 & $\mathrm{CF}$ & 63 & 3.85 & - & -- & -- & -- \\
\hline $27-28$ & 0700 & 12.4 & 29 & OC & 32 & 4.20 & -- & -- & -- & - \\
\hline \multicolumn{11}{|l|}{ AUG } \\
\hline $14-14$ & 1300 & 1.27 & 1 & OC & 51 & 4.16 & -- & -- & -- & - \\
\hline $19-20$ & 1500 & 30.2 & 12 & CF & 35 & 4.10 & -- & .440 & $<.001$ & .005 \\
\hline $23-23$ & 0600 & 1.52 & 3 & CF & 88 & 3.68 & -- & -- & -- & -- \\
\hline $24-24$ & 1730 & 2.29 & 1 & ND & 28 & 4.19 & .200 & -- & -- & -- \\
\hline \multicolumn{11}{|l|}{ SEPT } \\
\hline $03-04$ & 0500 & 11.9 & 26 & OC & 34 & 4.10 & .130 & .320 & $<.001$ & .003 \\
\hline $11-12$ & 2100 & 5.08 & 7 & CF & 55 & 3.82 & .245 & .960 & -- & -- \\
\hline $14-14$ & 1000 & 1.27 & 4 & $\mathrm{CF}$ & 50 & 4.00 & -- & -- & -- & -- \\
\hline $15-15$ & 0500 & 5.08 & 16 & OC & 35 & 4.10 & .247 & .300 & -- & $<.010$ \\
\hline \multicolumn{11}{|l|}{ OCT } \\
\hline 01-02 & 1300 & 62.5 & 28 & OC & 9 & 4.72 & .050 & .050 & - & $<.001$ \\
\hline 03-03 & 2100 & .76 & 1 & CF & 71 & 3.90 & -- & -- & .008 & -- \\
\hline $22-23$ & 1800 & 28.2 & 10 & CF & 27 & 4.19 & .200 & .460 & -- & .015 \\
\hline $29-29$ & 1200 & 2.03 & 3 & ND & 49 & 3.95 & -- & -- & $<.001$ & $\therefore$ \\
\hline \multicolumn{11}{|l|}{ NOV } \\
\hline $05-05$ & 0500 & 9.65 & 7 & OC & 15 & 4.46 & .060 & -- & -- & .013 \\
\hline $09-10$ & 2200 & 2.54 & 11 & ND & 25 & 4.40 & -- & - & $<.001$ & -- \\
\hline $11-12$ & 1000 & 31.2 & 25 & CF & 3 & 5.16 & $<.001$ & -- & -- & .011 \\
\hline $15-15$ & 1900 & 2.03 & 4 & CF & 43 & 4.01 & -- & -- & $<.001$ & -- \\
\hline $29-29$ & 0300 & 13.5 & 6 & CF & 15 & 4.60 & .103 & .100 & -- & .003 \\
\hline \multicolumn{11}{|l|}{ DEC } \\
\hline 03-03 & 1200 & 9.14 & 10 & $\mathrm{CC}$ & 15 & 4.50 & .040 & .200 & -- & $<.001$ \\
\hline 06-06 & 0000 & 19.1 & 15 & OC & 8 & 4.75 & .005 & .090 & -- & $<.001$ \\
\hline $10-10$ & 1000 & 1.02 & 8 & ND & 58 & 3.90 & -- & -- & $<.001$ & -- \\
\hline $19-19$ & 1400 & 8.89 & 3 & $\mathrm{CC}$ & 30 & 4.16 & .203 & .320 & -- & $<.001$ \\
\hline $21-22$ & 1800 & 24.1 & 19 & $\mathrm{CC}$ & 21 & 4.32 & .103 & .190 & $<.001$ & $<.001$ \\
\hline $24-25$ & 1100 & 2.79 & 14 & ND & 43 & 4.00 & -- & -- & $<.001$ & - \\
\hline $28-28$ & 0700 & 2.54 & 15 & ND & 35 & 4.09 & -- & -- & -- &.- \\
\hline
\end{tabular}


Table 21. Physical data and chemical-constituent concentrations for storm-precipitation samples collected at Princeton, Massachusetts, September 1983 through April 1985--Continued

\begin{tabular}{|c|c|c|c|c|c|c|c|c|c|c|}
\hline Date & $\begin{array}{l}\text { Storm } \\
\text { start } \\
\text { time } \\
\text { (h) }\end{array}$ & $\begin{array}{l}\text { Precip- } \\
\text { itation, } \\
\text { total } \\
\text { (mm) }\end{array}$ & $\begin{array}{l}\text { Storm } \\
\text { dura- } \\
\text { tion } \\
\text { (h) }\end{array}$ & $\begin{array}{l}\text { Storm } \\
\text { type }\end{array}$ & $\begin{array}{c}\text { Spe- } \\
\text { cific } \\
\text { conduct- } \\
\text { ance } \\
(\mu \mathrm{S} / \mathrm{cm})\end{array}$ & $\begin{array}{c}\mathrm{pH} \\
\text { (stand- } \\
\text { ard } \\
\text { units) }\end{array}$ & $\begin{array}{l}\text { Nitrogen, } \\
\text { ammonia, } \\
\text { dissolved } \\
\text { (mg/L } \\
\text { as N) }\end{array}$ & $\begin{array}{l}\text { Nitrogen, } \\
\text { nitrate, } \\
\text { dissolved } \\
\text { (mg/L } \\
\text { as } \mathrm{N})\end{array}$ & $\begin{array}{l}\text { Phos- } \\
\text { phorus, } \\
\text { dissolved } \\
\text { (mg/L } \\
\text { as } \mathrm{P} \text { ) }\end{array}$ & $\begin{array}{l}\text { Phos- } \\
\text { phorus, } \\
\text { ortho, } \\
\text { dissolved } \\
\text { (mg/L } \\
\text { as P) }\end{array}$ \\
\hline \multicolumn{11}{|l|}{ JAN 1985} \\
\hline $01-02$ & 1200 & 9.91 & 26 & $\mathrm{CC}$ & 30 & 4.20 & 0.134 & 0.300 & $<0.001$ & $<0.001$ \\
\hline $07-08$ & 1900 & 5.84 & 10 & $\mathrm{CF}$ & 26 & 4.20 & -- & -- & -- & -- \\
\hline $17-17$ & 0600 & 2.54 & 16 & $\mathrm{OC}$ & 20 & 4.31 & -- & - & -- & - \\
\hline \multicolumn{11}{|l|}{ FEB } \\
\hline $01-03$ & 1000 & 8.64 & 43 & CF & 26 & 4.21 & .027 & .500 & -- & -- \\
\hline $05-06$ & 1600 & 3.81 & 21 & $\mathrm{OC}$ & 27 & 4.30 & -- & -- & -- & -- \\
\hline $12-13$ & 1600 & 42.4 & 17 & $\mathrm{CC}$ & 18 & 4.43 & .035 & .170 & 0.051 & $<.001$ \\
\hline \multicolumn{11}{|l|}{ MAR } \\
\hline 04-05 & 1200 & 19.1 & 24 & $\mathrm{CC}$ & 30 & 4.15 & .263 & .181 & $<.001$ & $<.001$ \\
\hline $07-08$ & 2200 & 3.30 & 11 & ND & 32 & 4.19 & -- & -- & -- & -- \\
\hline $11-12$ & 2310 & 36.6 & 17 & $\mathrm{CC}$ & 20 & 4.35 & .148 & .210 & $<.001$ & $<.001$ \\
\hline $17-18$ & 1800 & 8.64 & 19 & $\mathrm{OC}$ & 50 & 3.92 & - & -- & -- & -- \\
\hline $28-28$ & 1600 & .76 & 5 & CF & 104 & 3.78 & -- & -- & -- & -- \\
\hline \multicolumn{11}{|l|}{ APR } \\
\hline $08-08$ & 0000 & 15.2 & 8 & $O C$ & 15 & 4.52 & -- & - & -- & $\therefore$ \\
\hline $22-22$ & 0130 & 9.40 & 4 & ND & 36 & 4.35 & 1.20 & .580 & -- & $<.010$ \\
\hline $28-28$ & 1300 & 3.30 & 6 & CF & 16 & 4.43 & -- & -- & -- & -- \\
\hline \multicolumn{11}{|l|}{ SEPT } \\
\hline $26-27$ & 2330 & 42.2 & 17 & $\mathrm{OC}$ & 19 & 4.50 & .165 & .130 & .003 & $<.010$ \\
\hline $\begin{array}{c}\text { Date } \\
.\end{array}$ & $\begin{array}{l}\text { Carbon, } \\
\text { organic, } \\
\text { total } \\
(\mathrm{mg} / \mathrm{L})\end{array}$ & $\begin{array}{l}\text { Calcium, } \\
\text { dis- } \\
\text { solved } \\
(\mathrm{mg} / \mathrm{L})\end{array}$ & $\begin{array}{l}\text { Magne- } \\
\text { sium, } \\
\text { dis- } \\
\text { solved } \\
(\mathrm{mg} / \mathrm{L})\end{array}$ & $\begin{array}{l}\text { Sodium, } \\
\text { dis- } \\
\text { solved } \\
(\mathrm{mg} / \mathrm{L})\end{array}$ & $\begin{array}{l}\text { Potas- } \\
\text { sium, } \\
\text { dissolved } \\
\text { (mg/L) }\end{array}$ & $\begin{array}{c}\text { Chloride, } \\
\text { dissolved } \\
\text { (mg/L) }\end{array}$ & $\begin{array}{c}\text { Sulfate, } \\
\text { dissolved } \\
(\mathrm{mg} / \mathrm{L})\end{array}$ & $\begin{array}{l}\text { Fluoride, } \\
\text { dissolved } \\
(\mathrm{mg} / \mathrm{L})\end{array}$ & $\begin{array}{l}\text { Silica, } \\
\text { dissolved } \\
(\mathrm{mg} / \mathrm{L})\end{array}$ & $\begin{array}{c}\text { Arsenic, } \\
\text { dissolved } \\
(\mu \mathrm{g} / \mathrm{L})\end{array}$ \\
\hline \multicolumn{11}{|l|}{ SEPT 1983} \\
\hline $16-17$ & -- & 0.12 & 0.06 & 0.09 & 0.04 & 1.01 & 3.40 & 0.05 & -- & -- \\
\hline $21-22$ & -- & .03 & .01 & .09 & .01 & $<.20$ & .47 & $<.01$ & 0.01 & - \\
\hline \multicolumn{10}{|l|}{ SEPT 30- } & -- \\
\hline \multicolumn{11}{|l|}{ OCT } \\
\hline $23-24$ & -- & .04 & .08 & .50 & .01 & $<.20$ & .42 & $<.01$ & $<.01$ & $<1$ \\
\hline \multicolumn{11}{|l|}{ NOV } \\
\hline $10-11$ & -- & .04 & $<.01$ & $<.20$ & .01 & $<.20$ & 1.32 & $<.01$ & $<.01$ & $<1$ \\
\hline $15-16$ & -- & .02 & .05 & .40 & $<.01$ & $<.20$ & .58 & $<.01$ & $<.01$ & $<1$ \\
\hline $21-21$ & - & .07 & $<.01$ & .30 & .01 & .33 & 1.21 & $<.01$ & $<.01$ & -- \\
\hline $24-25$ & -- & .02 & $<.01$ & $<.20$ & .01 & $<.20$ & .40 & $<.01$ & $<.01$ & -- \\
\hline $28-29$ & -- & .05 & $<.01$ & .20 & .01 & $<.20$ & 1.18 & $<.01$ & $<.01$ & -- \\
\hline \multicolumn{11}{|l|}{$\mathrm{DEC}$} \\
\hline $06-07$ & -- & .04 & $<.01$ & $<.20$ & .01 & $<.20$ & 1.32 & .02 & $<.01$ & -- \\
\hline $10-10$ & -- & - & -- & -- & -- & -- & -- & -- & -- & -- \\
\hline $12-14$ & - & .05 & .08 & 1.0 & .04 & 1.73 & 1.22 & $<.01$ & $<.01$ & $<1$ \\
\hline $22-22$ & - & - & -- & - & -- & -- & -- & -- & -- & -- \\
\hline $28-28$ & - & .04 & .04 & .30 & .02 & 1.01 & 1.04 & $<.01$ & .01 & -- \\
\hline
\end{tabular}


Table 21. Physical data and chemical-constituent concentrations for storm-precipitation samples collected at Princeton, Massachusetts, September 1983 through April 1985--Continued

\begin{tabular}{|c|c|c|c|c|c|c|c|c|c|c|}
\hline Date & $\begin{array}{c}\text { Carbon, } \\
\text { organic, } \\
\text { total } \\
(\mathrm{mg} / \mathrm{L})\end{array}$ & $\begin{array}{l}\text { Calcium, } \\
\text { dis- } \\
\text { solved } \\
\text { (mg/L) }\end{array}$ & $\begin{array}{l}\text { Magne- } \\
\text { sium, } \\
\text { dis- } \\
\text { solved } \\
\text { (mg/L) }\end{array}$ & $\begin{array}{l}\text { Sodium, } \\
\text { dis- } \\
\text { solved } \\
(\mathrm{mg} / \mathrm{L})\end{array}$ & $\begin{array}{c}\text { Potas- } \\
\text { sium, } \\
\text { dissolved } \\
(\mathrm{mg} / \mathrm{L})\end{array}$ & $\begin{array}{c}\text { Chloride, } \\
\text { dissolved } \\
(\mathrm{mg} / \mathrm{L})\end{array}$ & $\begin{array}{l}\text { Sulfate, } \\
\text { dissolved } \\
(\mathrm{mg} / \mathrm{L})\end{array}$ & $\begin{array}{l}\text { Fluoride, } \\
\text { dissolved } \\
(\mathrm{mg} / \mathrm{L})\end{array}$ & $\begin{array}{c}\text { Silica, } \\
\text { dissolved } \\
(\mathrm{mg} / \mathrm{L})\end{array}$ & $\begin{array}{c}\text { Arsenic, } \\
\text { dissolved } \\
(\mu \mathrm{g} / \mathrm{L})\end{array}$ \\
\hline \multicolumn{11}{|l|}{ JAN 1984} \\
\hline 18-19 & -- & -- & -- & -. & -- & -- & - & -- & -- & $\cdots$ \\
\hline $24-24$ & -- & 0.03 & $<0.01$ & 0.50 & 0.04 & 0.81 & 1.40 & $<0.01$ & $<0.01$ & -- \\
\hline $30-31$ & -- & .10 & .01 & .30 & .18 & .51 & .45 & $<.01$ & - & -- \\
\hline \multicolumn{11}{|l|}{ FEB } \\
\hline $11-11$ & -- & .03 & -- & -- & - & -- & -- & -- & -- & -- \\
\hline $14-16$ & -- & .03 & .05 & .20 & .01 & .33 & .75 & .03 & $<.01$ & -- \\
\hline $24-24$ & -- & .08 & $<.01$ & $<.20$ & .02 & .22 & .76 & $<.01$ & $<.01$ & $\cdots$ \\
\hline $28-29$ & -- & -- & .03 & $<.20$ & .03 & $<.20$ & .49 & .02 & $<.01$ & -- \\
\hline \multicolumn{11}{|l|}{ MAR } \\
\hline $05-06$ & -- & -- & -- & - & -- & -- & -- & -- & $\ldots$ & -- \\
\hline $13-14$ & -- & .06 & -- & -- & -- & -- & -- & -- & - & -- \\
\hline $21-21$ & -- & .02 & .03 & .22 & .04 & .44 & 1.33 & $<.01$ & - & -- \\
\hline $29-30$ & -- & .07 & .05 & $<.20$ & .03 & .24 & .40 & $<.01$ & $<.01$ & $<1$ \\
\hline \multicolumn{11}{|l|}{ APR } \\
\hline 04-05 & -- & .12 & .01 & .30 & .05 & .39 & 1.70 & $<.01$ & $<.01$ & 1 \\
\hline $14-16$ & -- & -. & .04 & $<.20$ & .03 & .21 & 2.08 & $<.01$ & $<.01$ & 1 \\
\hline $20-20$ & -- & .23 & - & -- & - & -- & -- & -- & - & -- \\
\hline $23-25$ & - & .07 & .03 & $<.20$ & .03 & $<.20$ & 1.18 & .03 & - & $<1$ \\
\hline \multicolumn{11}{|l|}{ MAY } \\
\hline 03-05 & -- & .07 & .06 & $<.20$ & .03 & $<.20$ & 1.71 & $<.01$ & -- & $<1$ \\
\hline $08-08$ & - & .08 & .06 & $<.20$ & .07 & $<.20$ & 1.00 & $<.01$ & -- & $<1$ \\
\hline $23-23$ & -- & .08 & $<.01$ & $<.20$ & .06 & $<.20$ & .95 & $<.01$ & $\sim$ & $<1$ \\
\hline $26-26$ & -- & .11 & .03 & .25 & .18 & .32 & 3.55 & $<.01^{\circ}$ & - & -- \\
\hline $28-31$ & -- & .14 & .06 & $<.20$ & .02 & .25 & .66 & $<.01$ & -- & $<1$ \\
\hline \multicolumn{11}{|l|}{ JUNE } \\
\hline $01-02$ & -- & .03 & .04 & $<.20$ & .01 & $<.20$ & .40 & $<.01$ & -- & $<1$ \\
\hline $14-14$ & -- & -- & - & -- & -- & - & - & -- & -- & -- \\
\hline $18-19$ & -- & .19 & .03 & .12 & .14 & .32 & 11.5 & .04 & -- & -- \\
\hline $26-26$ & -- & -- & -- & -- & -- & -- & -- & -- & -- & -- \\
\hline $29-29$ & -- & -- & -- & -- & -- & - & -- & -- & -- & -- \\
\hline \multicolumn{11}{|l|}{ JULY } \\
\hline $15-16$ & -- & -- & -- & -- & -- & -- & -- & -- & - & - \\
\hline $16-16$ & -- & -- & -- & -- & -- & -- & -- & -- & -- & -- \\
\hline $18-18$ & -- & -- & -- & -- & -- & -- & -- & -- & - & -- \\
\hline $21-21$ & -- & -- & -- & -- & -- & -- & -- & - & - & - \\
\hline $27-28$ & -- & -- & -- & -- & -- & - & - & - & -- & -- \\
\hline \multicolumn{11}{|l|}{ AUG } \\
\hline $14-14$ & -- & -- & .. & - & -- & -- & -- & -- & -- & -- \\
\hline $19-20$ & -- & .04 & $<.01$ & $<.20$ & .04 & $<.20$ & 2.28 & $<.01$ & -- & 1 \\
\hline $23-23$ & -- & - & -- & - & -- & -- & -- & -- & -- & -- \\
\hline $24-24$ & -- & -- & - & -- & -- & -- & -- & -- & .01 & -- \\
\hline \multicolumn{11}{|l|}{ SEPT } \\
\hline 03-04 & -- & .06 & $<.01$ & $<.20$ & .01 & $<.20$ & 2.75 & $<.01$ & -- & -- \\
\hline $11-12$ & -- & .19 & .05 & .17 & .06 & .33 & 4.18 & .03 & -- & -- \\
\hline $14-14$ & -- & -- & -- & - & -- & -- & -- & -- & - & - \\
\hline $15-15$ & -- & .11 & .01 & -- & .05 & .16 & 3.40 & $<.01$ & -- & -- \\
\hline
\end{tabular}


Table 21. Physical data and chemical-constituent concentrations for storm-preclpitation samples collected at Princeton, Massachusetts, September 1983 through April 1985--Continued

\begin{tabular}{|c|c|c|c|c|c|c|c|c|c|c|}
\hline Date & $\begin{array}{c}\text { Carbon, } \\
\text { organic, } \\
\text { total } \\
(\mathrm{mg} / \mathrm{L})\end{array}$ & $\begin{array}{l}\text { Calcium, } \\
\text { dis- } \\
\text { solved } \\
(\mathrm{mg} / \mathrm{L})\end{array}$ & $\begin{array}{l}\text { Magne- } \\
\text { sium, } \\
\text { dis- } \\
\text { solved } \\
(\mathrm{mg} / \mathrm{L})\end{array}$ & $\begin{array}{l}\text { Sodium, } \\
\text { dis- } \\
\text { solved } \\
(\mathrm{mg} / \mathrm{L})\end{array}$ & $\begin{array}{l}\text { Potas- } \\
\text { sium, } \\
\text { dissolved } \\
(\mathrm{mg} / \mathrm{L})\end{array}$ & $\begin{array}{c}\text { Chloride, } \\
\text { dissolved } \\
\text { (mg/L) }\end{array}$ & $\begin{array}{l}\text { Sulfate, } \\
\text { dissolved } \\
(\mathrm{mg} / \mathrm{L})\end{array}$ & $\begin{array}{c}\text { Fluoride, } \\
\text { dissolved } \\
\text { (mg/L) }\end{array}$ & $\begin{array}{c}\text { Silica, } \\
\text { dissolved } \\
(\mathrm{mg} / \mathrm{L})\end{array}$ & $\begin{array}{c}\text { Arsenic, } \\
\text { dissolved } \\
(\mu \mathrm{g} / \mathrm{L})\end{array}$ \\
\hline \multicolumn{11}{|l|}{$\overline{\text { OCT } 1984}$} \\
\hline $01-02$ & -- & $<0.02$ & $<0.01$ & $<0.20$ & 0.04 & 0.07 & 0.75 & $<0.01$ & -- & $<1$ \\
\hline 03-03 & -- & -- & -- & -- & $\sim$ & -- & -- & -- & -- & -- \\
\hline $22-23$ & -- & .06 & .02 & $<.20$ & $<.01$ & .08 & 1.80 & $<.01$ & 0.01 & $<1$ \\
\hline $29-29$ & -- & -- & -- & -- & - & -- & -- & -- & -- & -- \\
\hline \multicolumn{11}{|l|}{ NOV } \\
\hline $05-05$ & -- & .03 & .05 & .30 & .01 & .10 & .20 & -- & $<.01$ & -- \\
\hline $09-10$ & -- & -- & -- & -- & -- & -- & -- & -- & -- & -- \\
\hline $11-12$ & -- & -- & -- & - & - & -. & - & - & $<.01$ & $<1$ \\
\hline $15-15$ & -- & -- & -- & -- & -- & -- & -- & -- & -- & -- \\
\hline $29-29$ & -- & .10 & .07 & .48 & .12 & .90 & 1.10 & $<.01$ & .04 & -- \\
\hline \multicolumn{11}{|l|}{$\mathrm{DEC}$} \\
\hline 03-03 & -- & .08 & .02 & .08 & .02 & .01 & .90 & .01 & .02 & -- \\
\hline $06-06$ & -- & .07 & .02 & .10 & .03 & $<.10$ & .55 & .02 & .03 & -- \\
\hline $10-10$ & -- & -- & -- & - & - & -- & -- & -- & -- & -- \\
\hline $19-19$ & -- & .11 & .01 & .13 & .03 & .12 & 1.90 & .01 & $<.01$ & -- \\
\hline $21-22$ & -- & .06 & .02 & .08 & .04 & .20 & 1.20 & $<.01$ & $<.01$ & $<1$ \\
\hline $24-25$ & -- & -- & -- & -- & -- & -- & -- & - & -- & -- \\
\hline $28-28$ & -- & - & -- & -- & -- & -- & -- & - & -- & -- \\
\hline \multicolumn{11}{|l|}{ JAN 1985} \\
\hline $01-02$ & -- & .10 & .04 & .13 & .03 & .24 & 1.80 & .01 & $<.01$ & -- \\
\hline $07-08$ & -- & -- & -- & -- & -- & -- & -- & - & $<.01$ & - \\
\hline $17-17$ & -- & -- & -- & -- & -. & -- & -- & -- & -- & -- \\
\hline \multicolumn{11}{|l|}{ FEB } \\
\hline $01-03$ & -- & .14 & .02 & .10 & .03 & .27 & 1.60 & .03 & .02 & -- \\
\hline 05-06 & -- & -- & -- & -- & -- & -- & -- & -- & -- & -- \\
\hline $12-13$ & 0.6 & .07 & .08 & .70 & .06 & 1.20 & 1.90 & .64 & .05 & $<1$ \\
\hline \multicolumn{11}{|l|}{ MAR } \\
\hline $04-05$ & 1.7 & .08 & .02 & .23 & .01 & .26 & 2.50 & .04 & .04 & $<1$ \\
\hline $07-08$ & -- & -- & -- & -- & - & -. & -- & - & -- & -- \\
\hline $11-12$ & 1.7 & .06 & .01 & .09 & .02 & .06 & 1.20 & .02 & $<.01$ & $<1$ \\
\hline $17-18$ & -- & -- & -- & -- & -- & -- & -- & -- & -- & -- \\
\hline $28-28$ & -- & -- & -- & -- & -- & -- & -- & -- & - & -- \\
\hline \multicolumn{11}{|l|}{ APR } \\
\hline $08-08$ & -- & -- & -- & -- & -- & -- & -- & -- & -- & -- \\
\hline $22-22$ & -- & .51 & .09 & .20 & .09 & .20 & 3.70 & .26 & -. & -. \\
\hline $28-28$ & -- & -- & -- & -- & -- & - & -- & -- & -- & -- \\
\hline \multicolumn{11}{|l|}{ SEPT } \\
\hline $26-27$ & -- & .13 & .12 & .82 & .05 & 1.50 & 1.50 & .02 & $<.01$ & $<1$ \\
\hline
\end{tabular}


Table 21. Physical data and chemical-constituent concentrations for storm-precipitation samples collected at Princeton, Massachusetts, September 1983 through April 1985--Continued

\begin{tabular}{|c|c|c|c|c|c|c|c|c|c|c|}
\hline Date & $\begin{array}{c}\text { Barium, } \\
\text { dissolved } \\
(\mu \mathrm{g} / \mathrm{L})\end{array}$ & $\begin{array}{c}\text { Beryl- } \\
\text { lium, } \\
\text { dis- } \\
\text { solved } \\
(\mu g / L)\end{array}$ & $\begin{array}{c}\text { Boron, } \\
\text { dissolved } \\
(\mu \mathrm{g} / \mathrm{L})\end{array}$ & $\begin{array}{c}\text { Cadmium, } \\
\text { dissolved } \\
(\mu \mathrm{g} / \mathrm{L})\end{array}$ & $\begin{array}{l}\text { Chro--: } \\
\text { mium, } \\
\text { dis- } \\
\text { solved } \\
(\mu \mathrm{g} / \mathrm{L})\end{array}$ & $\begin{array}{c}\text { Cobalt, } \\
\text { dissolved } \\
(\mu \mathrm{g} / \mathrm{L})\end{array}$ & $\begin{array}{c}\text { Copper, } \\
\text { dissolved } \\
(\mu \mathrm{g} / \mathrm{L})\end{array}$ & $\begin{array}{c}\text { Iron, } \\
\text { dissolved } \\
(\mu \mathrm{g} / \mathrm{L})\end{array}$ & $\begin{array}{l}\text { Lead, } \\
\text { dissolved } \\
(\mu \mathrm{g} / \mathrm{L})\end{array}$ & $\begin{array}{c}\text { Man- } \\
\text { ganese, } \\
\text { dis- } \\
\text { solved } \\
(\mu \mathrm{g} / \mathrm{L})\end{array}$ \\
\hline \multicolumn{11}{|l|}{ SEPT 1983} \\
\hline $16-17$ & -- & -- & -- & -- & -- & -- & - & -- & -- & -- \\
\hline $21-22$ & 9 & 0.5 & -- & 1 & -- & 3 & 10 & 3 & 10 & 1 \\
\hline \multicolumn{11}{|l|}{ SEP 30- } \\
\hline ОСТ 02 & 26 & $<.5$ & -- & $<1$ & -- & $<3$ & $<10$ & $<3$ & $<10$ & $<1$ \\
\hline \multicolumn{11}{|l|}{ OCT } \\
\hline $23-24$ & - & - & - & -- & -- & - & $<0$ & $<3$ & 1 & $<1$ \\
\hline \multicolumn{11}{|l|}{ NOV } \\
\hline $10-11$ & - & - & -- & -- & -- & -- & 0 & $<3$ & 3 & $<1$ \\
\hline $15-16$ & -- & - & -- & -- & -- & -- & 0 & 4 & 1 & $<1$ \\
\hline $21-21$ & -. & - & -- & -- & -- & -- & -- & 5 & -- & $<1$ \\
\hline $24-25$ & -- & -- & -- & -- & -- & -- & -- & 3 & -- & $<1$ \\
\hline $28-29$ & - & -- & - & -- & -- & -- & -- & 5 & -- & $<1$ \\
\hline \multicolumn{11}{|l|}{ DEC } \\
\hline $06-07$ & -- & -- & -- & - & -- & -- & -- & 7 & -- & $<1$ \\
\hline $10-10$ & - & -- & -- & -- & -- & - & -- & -- & - & -- \\
\hline $12-14$ & - & -- & -- & -- & - & -- & 2 & $<3$ & 1 & $<1$ \\
\hline 22-22 & -- & -- & -- & -- & -- & -- & -- & -- & -- & -- \\
\hline $28-28$ & - & -- & - & -- & -- & -- & -- & 67 & -- & 1 \\
\hline \multicolumn{11}{|l|}{ JAN 1984} \\
\hline $18-19$ & - & -- & -- & -- & - & -- & -- & -- & - & -- \\
\hline $24-24$ & -- & -- & -- & -- & -- & -- & -- & $<3$ & -- & $<1$ \\
\hline $30-31$ & - & -- & -- & -- & -- & - & -- & 3 & -- & $<1$ \\
\hline \multicolumn{11}{|l|}{ FEB } \\
\hline $11-11$ & - & -- & -- & - & -- & -- & -- & -- & - & - \\
\hline $14-16$ & - & -. & -- & -- & -- & -- & 2 & 6 & 2 & $<1$ \\
\hline $24-24$ & -- & -- & -- & - & - & -- & -- & 130 & -- & 2 \\
\hline $28-29$ & $\rightarrow$ & -- & -- & -- & -- & -- & -- & 15 & -- & $<1$ \\
\hline \multicolumn{11}{|l|}{ MAR } \\
\hline $05-06$ & - & -- & -- & -- & - & - & -- & -- & - & - \\
\hline $13-14$ & - & -- & -- & -- & -- & -- & - & -- & - & -- \\
\hline 21-21 & - & -- & -- & -- & -- & -- & - & - & - & -- \\
\hline $29-30$ & - & -- & -- & -- & -- & -- & 4 & 7 & 2 & $<1$ \\
\hline \multicolumn{11}{|l|}{ APR } \\
\hline 04-05 & - & -- & -- & -- & -- & -- & 2 & 11 & 3 & $<1$ \\
\hline $14-16$ & -- & -- & -- & -- & -- & -- & 4 & 6 & 7 & 1 \\
\hline $20-20$ & $\cdots$ & - & -- & -- & -- & -- & -- & -- & -- & - \\
\hline $23-25$ & - & -- & -- & - & - & - & 8 & $<3$ & 4 & 2 \\
\hline \multicolumn{11}{|l|}{ MAY } \\
\hline 03-05 & - & -- & -- & -- & -- & -- & 2 & 6 & 3 & 1 \\
\hline 08-08 & - & - & -- & -- & -- & $\cdots$ & 9 & 8 & 5 & $<1$ \\
\hline 23-23 & - & -- & -- & -- & -- & -- & 4 & 10 & 2 & 2 \\
\hline $26-26$ & - & -- & -- & -- & -- & -- & -- & $<3$ & - & 3 \\
\hline $28-31$ & - & -- & -- & -- & -- & -- & 40 & 7 & 1 & $<1$ \\
\hline
\end{tabular}


Table 21. Physical data and chemical-constituent concentrations for storm-precipitation samples collected at Princeton, Massachusetts, September 1983 through April 1985--Continued

\begin{tabular}{|c|c|c|c|c|c|c|c|c|c|c|}
\hline Date & $\begin{array}{c}\text { Barium, } \\
\text { dissolved } \\
(\mu \mathrm{g} / \mathrm{L})\end{array}$ & $\begin{array}{l}\text { Beryl- } \\
\text { lium, } \\
\text { dis- } \\
\text { solved } \\
(\mu \mathrm{g} / \mathrm{L})\end{array}$ & $\begin{array}{l}\text { Boron, } \\
\text { dissolved } \\
(\mu \mathrm{g} / \mathrm{L})\end{array}$ & $\begin{array}{c}\text { Cadmium, } \\
\text { dissolved } \\
(\mu \mathrm{g} / \mathrm{L})\end{array}$ & $\begin{array}{l}\text { Chro- } \\
\text { mium, } \\
\text { dis- } \\
\text { solved } \\
(\mu \mathrm{g} / \mathrm{L})\end{array}$ & $\begin{array}{l}\text { Cobalt, } \\
\text { dissolved } \\
(\mu \mathrm{g} / \mathrm{L})\end{array}$ & $\begin{array}{l}\text { Copper, } \\
\text { dissolved } \\
(\mu \mathrm{g} / \mathrm{L})\end{array}$ & $\begin{array}{c}\text { Iron, } \\
\text { dissolved } \\
(\mu \mathrm{g} / \mathrm{L})\end{array}$ & $\begin{array}{c}\text { Lead, } \\
\text { dissolved } \\
(\mu \mathrm{g} / \mathrm{L})\end{array}$ & $\begin{array}{c}\text { Man- } \\
\text { ganese, } \\
\text { dis- } \\
\text { solved } \\
(\mu \mathrm{g} / \mathrm{L})\end{array}$ \\
\hline \multicolumn{11}{|c|}{ JUNE 1984} \\
\hline $01-02$ & -- & .- & -- & -- & -- & -- & 2 & 5 & 1 & $<1$ \\
\hline $14-14$ & -- & -- & -- & $\cdots$ & -- & - & -- & -. & - & -- \\
\hline $18-19$ & -- & -- & -- & -- & -. & -- & -- & -- & - & -- \\
\hline $26-26$ & -- & -- & -- & - & -- & -- & -- & -- & -- & -- \\
\hline $29-29$ & -- & -- & -- & -- & -- & -- & -- & -- & -- & .. \\
\hline \multicolumn{11}{|l|}{ JULY } \\
\hline $15-16$ & -- & -- & -- & -- & -- & -- & -- & -- & -- & -- \\
\hline $16-16$ & -- & -- & -- & -- & -- & -- & - & -- & - & -- \\
\hline $18-18$ & -- & -- & -- & - & -- & - & -- & -- & -- & -- \\
\hline $21-21$ & -- & -- & -- & -- & -- & -. & -- & -- & -- & -- \\
\hline $27-28$ & -- & - & -- & -- & -- & -- & -- & -. & -- & -- \\
\hline \multicolumn{11}{|l|}{ AUG } \\
\hline $14-14$ & -- & -- & -- & -- & -- & -- & -- & -- & -. & -- \\
\hline $19-20$ & -- & -- & -- & -- & - & -- & 2 & 9 & 8 & $<1$ \\
\hline $23-23$ & -- & -- & -- & -- & -- & - & -- & - & -- & -- \\
\hline $24-24$ & -- & -- & $<20$ & $\cdots$ & -- & - & -- & - & -- & -- \\
\hline \multicolumn{11}{|l|}{ SEPT } \\
\hline 03-04 & -- & -- & -- & -- & -- & -. & -- & 5 & -- & 1 \\
\hline $11-12$ & -- & -- & -- & -- & -- & -- & -- & -- & -- & -- \\
\hline $14-14$ & -- & -- & -- & -- & -- & -- & -. & -- & - & -- \\
\hline $15-15$ & -- & - & -- & -- & -- & -- & -. & -- & - & -- \\
\hline OCT & & & & & & & & & & \\
\hline $01-02$ & -- & -- & -- & -- & -- & -- & $<0$ & $<3$ & 1 & $<1$ \\
\hline $03-03$ & -- & -. & -- & -- & -- & -- & -- & -- & -- & -- \\
\hline $22-23$ & -- & -- & $<20$ & -- & -- & -- & $<0$ & 4 & 4 & $<1$ \\
\hline $29-29$ & -- & -- & -- & -- & -- & -- & -- & -- & - & -- \\
\hline \multicolumn{11}{|l|}{ NOV } \\
\hline $05-05$ & -- & -- & - & -- & - & -- & 1 & 5 & 2 & $<1$ \\
\hline $09-10$ & -- & -. & -- & -- & -- & - & -- & -- & -- & -- \\
\hline $11-12$ & 13 & -- & $<20$ & 1 & -- & $<3$ & 3 & 4 & 1 & $<1$ \\
\hline $15-15$ & -- & -- & -- & -- & -- & -- & -- & -- & -- & -- \\
\hline $29-29$ & 13 & $<0.5$ & -- & $<1$ & -- & $<3$ & -- & 4 & - & 1 \\
\hline \multicolumn{11}{|l|}{ DEC } \\
\hline 03-03 & 13 & $<.5$ & 30 & $<1$ & - & $<3$ & -- & 3 & - & $<1$ \\
\hline $06-06$ & 16 & .7 & $<20$ & $<1$ & -- & $<3$ & $<10$ & 12 & - & $<1$ \\
\hline $10-10$ & -- & -- & -- & -. & - & - & -- & -- & -- & -- \\
\hline $19-19$ & 12 & $<.5$ & $<20$ & $<1$ & -- & $<3$ & - & 7 & -- & $<1$ \\
\hline $21-22$ & 5 & $<.5$ & $<20$ & $<1$ & -- & $<3$ & 7 & 4 & 3 & $<1$ \\
\hline $24-25$ & -- & -- & -- & -- & -- & - & -- & -- & -- & -- \\
\hline $28-28$ & -- & -- & -- & -. & -- & - & -- & -- & -- & -- \\
\hline \multicolumn{11}{|l|}{ JAN 1985} \\
\hline 01-02 & 8 & $<.5$ & $<20$ & $<1$ & -- & $<3$ & -- & 4 & -- & $<1$ \\
\hline $07-08$ & 12 & $<.5$ & -- & $<1$ & -- & $<3$ & -- & 5 & -- & 1 \\
\hline $17-17$ & -- & -- & -- & -- & -- & -- & -- & -- & -. & -- \\
\hline \multicolumn{11}{|l|}{ FEB } \\
\hline $01-03$ & 14 & $<.5$ & 30 & $<1$ & -- & $<3$ & -- & 23 & -- & 2 \\
\hline $05-06$ & -- & -- & -- & -- & -- & -- & -- & -- & -- & -- \\
\hline $12-13$ & 12 & $<.5$ & $<20$ & $<1$ & -- & $<3$ & 1 & 8 & 1 & 1 \\
\hline
\end{tabular}


Table 21. Physical data and chemical-constituent concentrations for storm-precipitation samples collected at Princeton, Massachusetts, September 1983 through April. 1985--Continued

\begin{tabular}{|c|c|c|c|c|c|c|c|c|c|c|}
\hline Date & $\begin{array}{c}\text { Barium, } \\
\text { dissolved } \\
(\mu \mathrm{g} / \mathrm{L})\end{array}$ & $\begin{array}{l}\text { Beryl- } \\
\text { lium, } \\
\text { dis- } \\
\text { solved } \\
(\mu \mathrm{g} / \mathrm{L})\end{array}$ & $\begin{array}{c}\text { Boron, } \\
\text { dissolved } \\
(\mu \mathrm{g} / \mathrm{L})\end{array}$ & $\begin{array}{l}\text { Cadmium, } \\
\text { dissolved } \\
(\mu \mathrm{g} / L)\end{array}$ & $\begin{array}{l}\text { Chro- } \\
\text { mium, } \\
\text { dis- } \\
\text { solved } \\
(\mu \mathrm{g} / \mathrm{L})\end{array}$ & $\begin{array}{c}\text { Cobalt, } \\
\text { dissolved } \\
(\mu \mathrm{g} / \mathrm{L})\end{array}$ & $\begin{array}{c}\text { Copper, } \\
\text { dissolved } \\
(\mu \mathrm{g} / \mathrm{L})\end{array}$ & $\begin{array}{c}\text { Iron, } \\
\text { dissolved } \\
(\mu \mathrm{g} / \mathrm{L})\end{array}$ & $\begin{array}{l}\text { Lead, } \\
\text { dissolved } \\
(\mu \mathrm{g} / \mathrm{L})\end{array}$ & $\begin{array}{c}\text { Man- } \\
\text { ganese, } \\
\text { dis- } \\
\text { solved } \\
(\mu \mathrm{g} / \mathrm{L})\end{array}$ \\
\hline \multicolumn{11}{|l|}{ MAR 1985} \\
\hline $04-05$ & 14 & 0.6 & $<20$ & 2 & -- & $<3$ & 4 & 14 & 4 & 1 \\
\hline $07-08$ & -- & -- & .. & -. & -- & -- & -- & -- & -- & -- \\
\hline $11-12$ & 12 & $<.5$ & $<20$ & $<1$ & -- & $<3$ & 3 & 3 & 3 & $<1$ \\
\hline $17-18$ & -- & - & -- & -- & -- & -- & -- & -- & - & -- \\
\hline $28-28$ & -- & - & - & -- & -- & -- & -- & -- & -- & - \\
\hline \multicolumn{11}{|l|}{ APR } \\
\hline $08-08$ & -- & -- & -- & -- & - & -- & -- & -- & -- & -- \\
\hline $22-22$ & -- & -- & - & -- & -- & -- & 3 & 11 & 3 & 7 \\
\hline $28-28$ & -- & -- & -- & -- & -- & -. & -- & -- & -- & -- \\
\hline $26-27$ & 4 & $<.5$ & $<20$ & 2 & $<1$ & $<3$ & $<0$ & 5 & $<2$ & $<1$ \\
\hline Date & $\begin{array}{c}\text { Molyb- } \\
\text { denum, } \\
\text { dissolved } \\
(\mu \mathrm{g} / \mathrm{L})\end{array}$ & $\begin{array}{c}\text { Nickel, } \\
\text { dis- } \\
\text { solved } \\
(\mu \mathrm{g} / \mathrm{L})\end{array}$ & $\begin{array}{l}\text { Stron- } \\
\text { tium, } \\
\text { dis- } \\
\text { solved } \\
(\mu \mathrm{g} / \mathrm{L}) \\
\end{array}$ & $\begin{array}{c}\text { Vana- } \\
\text { dium, } \\
\text { dis- } \\
\text { solved } \\
(\mu \mathrm{g} / \mathrm{L}) \\
\end{array}$ & $\begin{array}{l}\text { Zinc, } \\
\text { dis- } \\
\text { solved } \\
(\mu \mathrm{g} / \mathrm{L})\end{array}$ & $\begin{array}{c}\text { Anti- } \\
\text { mony, } \\
\text { dis- } \\
\text { solved } \\
(\mu \mathrm{g} / \mathrm{L}) \\
\end{array}$ & $\begin{array}{l}\text { Alum- } \\
\text { inum, } \\
\text { dis- } \\
\text { solved } \\
(\mu \mathrm{g} / \mathrm{L}) \\
\end{array}$ & $\begin{array}{l}\text { Lith- } \\
\text { ium, } \\
\text { dis- } \\
\text { solved } \\
(\mu \mathrm{g} / \mathrm{L}) \\
\end{array}$ & $\begin{array}{c}\text { Sele- } \\
\text { nium, } \\
\text { dis } \\
\text { solved } \\
(\mu \mathrm{g} / \mathrm{L}) \\
\end{array}$ & $\begin{array}{c}\text { Bro- } \\
\text { mide, } \\
\text { dis- } \\
\text { solved } \\
(\mathrm{mg} / \mathrm{L}) \\
\end{array}$ \\
\hline \multicolumn{11}{|l|}{ SEPT 1983} \\
\hline $16-17$ & -- & - & -- & -- & -- & - & -- & -- & -- & $<0.10$ \\
\hline $21-22$ & 10 & -- & 0 & 6 & 3 & -- & -- & 4 & - & $<.10$ \\
\hline \multicolumn{11}{|l|}{ SEPT 30- } \\
\hline \multicolumn{11}{|l|}{ OCT } \\
\hline $23-24$ & -- & - & -- & $<1$ & - & -- & 70 & -- & $<1$ & $<.10$ \\
\hline \multicolumn{11}{|l|}{ NOV } \\
\hline $10-11$ & -- & -- & -- & 1 & -- & - & 20 & -- & 2 & $<.10$ \\
\hline $15-16$ & -. & -- & -- & 1 & -- & -- & $<10$ & $\cdots$ & $<1$ & $<.10$ \\
\hline $21-21$ & -- & -. & -- & -- & -- & - & -- & -- & - & $<.10$ \\
\hline $24-25$ & -- & -- & -- & -- & -- & -. & -- & -- & -- & $<.10$ \\
\hline $28-29$ & -- & - & -- & -- & -- & -- & -. & -- & -- & $<.10$ \\
\hline \multicolumn{11}{|l|}{ DEC } \\
\hline $06-07$ & -- & -- & - & -- & -- & -- & -- & .. & -- & $<.10$ \\
\hline $10-10$ & - & -- & -- & -- & -- & -- & -- & -- & - & -- \\
\hline $12-14$ & -- & -- & -- & 1 & -- & -- & $<10$ & -- & $<1$ & $<.10$ \\
\hline $22-22$ & -- & -- & -- & -- & -- & -- & -- & -- & -- & -- \\
\hline \multicolumn{11}{|l|}{ DEC } \\
\hline $28-28$ & - & -- & -- & -- & -- & -- & -- & -- & - & $<.10$ \\
\hline \multicolumn{11}{|l|}{ JAN 1984} \\
\hline $18-19$ & -- & -- & -- & -- & -- & -- & -- & -- & -- & - \\
\hline $24-24$ & -- & -- & -- & -- & -- & -- & -. & -- & -- & $<.10$ \\
\hline $30-31$ & -- & -- & -- & -- & - & -- & .. & -- & - & $<.10$ \\
\hline \multicolumn{11}{|l|}{ FEB } \\
\hline $11-11$ & -- & -- & -- & -- & -- & -- & -- & -. & - & -- \\
\hline $14-16$ & -- & -- & -. & 1 & -- & -- & 20 & -- & $<1$ & $<.10$ \\
\hline $24-24$ & -- & - & -- & -- & - & -- & - & -- & - & $<.10$ \\
\hline $28-29$ & -- & -- & -- & -. & -- & -- & -- & -- & -- & $<.10$ \\
\hline
\end{tabular}


Table 21. Physical data and chemical-constituent concentrations for storm-precipltation samples collected at Princeton, Massachusetts, September 1983 through April 1985--Continued

\begin{tabular}{|c|c|c|c|c|c|c|c|c|c|c|}
\hline Date & $\begin{array}{l}\text { Molyb- } \\
\text { denum, } \\
\text { dissolved } \\
(\mu \mathrm{g} / \mathrm{L})\end{array}$ & $\begin{array}{c}\text { Nickel, } \\
\text { dis- } \\
\text { solved } \\
(\mu \mathrm{g} / \mathrm{L})\end{array}$ & $\begin{array}{c}\text { Stron- } \\
\text { tium, } \\
\text { dis- } \\
\text { solved } \\
(\mu \mathrm{g} / \mathrm{L})\end{array}$ & $\begin{array}{c}\text { Vana- } \\
\text { dium, } \\
\text { dis- } \\
\text { solved } \\
(\mu \mathrm{g} / \mathrm{L})\end{array}$ & $\begin{array}{l}\text { Zinc, } \\
\text { dis- } \\
\text { solved } \\
(\mu \mathrm{g} / \mathrm{L})\end{array}$ & $\begin{array}{c}\text { Anti- } \\
\text { mony, } \\
\text { dis- } \\
\text { solved } \\
(\mu \mathrm{g} / \mathrm{L})\end{array}$ & $\begin{array}{c}\text { Alum- } \\
\text { inum, } \\
\text { dis- } \\
\text { solved } \\
(\mu \mathrm{g} / \mathrm{L})\end{array}$ & $\begin{array}{l}\text { Lith- } \\
\text { ium, } \\
\text { dis- } \\
\text { solved } \\
(\mu \mathrm{g} / \mathrm{L})\end{array}$ & $\begin{array}{c}\text { Sele- } \\
\text { nium, } \\
\text { dis } \\
\text { solved } \\
(\mu \mathrm{g} / \mathrm{L})\end{array}$ & $\begin{array}{c}\text { Bro- } \\
\text { mide, } \\
\text { dis- } \\
\text { solved } \\
(\mathrm{mg} / \mathrm{L})\end{array}$ \\
\hline \multicolumn{11}{|c|}{ MAR 1984} \\
\hline $05-06$ & -- & -- & -- & -- & - & -- & -- & $\therefore-$ & -- & -- \\
\hline $13-14$ & -- & -- & -- & -- & -- & -- & -- & "- & -- & -- \\
\hline $21-21$ & - & -. & -- & -. & -- & -- & -- & -- & -- & $<0.10$ \\
\hline $29-30$ & - & -- & -- & 2 & -- & -- & $<10$ & -- & $<1$ & $<.10$ \\
\hline \multicolumn{11}{|l|}{ APR } \\
\hline $04-05$ & -- & -- & -- & $<1$ & -- & -- & 10 & - & $<1$ & $<.10$ \\
\hline $14-16$ & - & -- & -- & -- & -- & -- & $<10$ & -- & -- & $<.10$ \\
\hline $20-20$ & $\cdots$ & -- & -- & -- & -- & -- & -- & -- & -- & -- \\
\hline $23-25$ & - & -- & -- & 1 & -- & -- & -- & -- & -- & -- \\
\hline \multicolumn{11}{|l|}{ MAY } \\
\hline 03-05 & -- & -- & -- & $<1$ & -- & -- & 10 & -. & $<1$ & -- \\
\hline $08-08$ & - & -- & -- & -- & -. & -- & -- & -- & -- & -- \\
\hline $23-23$ & - & -- & -- & $<1$ & -- & -- & -- & -- & -- & -- \\
\hline $26-26$ & - & -- & -- & -- & -- & -- & -- & -- & -- & -- \\
\hline $28-31$ & -- & -- & -- & $<1$ & -- & - & $<10$ & -- & $<1$ & -- \\
\hline \multicolumn{11}{|l|}{ JUNE } \\
\hline $01-02$ & -- & - & -- & $<1$ & -- & -- & -- & -- & $<1$ & -- \\
\hline $14-14$ & -- & -- & -- & -- & -- & -- & -- & -- & -. & -- \\
\hline $18-19$ & -- & - & -- & -- & -- & -- & -- & - & -- & -- \\
\hline $26-26$ & -- & -- & -- & -- & -- & -. & -- & -- & -- & -- \\
\hline $29-29$ & -- & -- & -- & -- & - & -- & -- & -- & - & -- \\
\hline \multicolumn{11}{|l|}{ JULY } \\
\hline $15-16$ & -- & - & -- & -- & -- & -- & - & -- & -- & -- \\
\hline $16-16$ & -- & -- & -- & -- & -- & -- & -- & -- & -- & -- \\
\hline $18-18$ & -- & -- & -- & -- & $\therefore$ & -- & -- & -- & -- & -- \\
\hline $21-21$ & -- & -- & -- & -- & -- & -- & -- & -- & -- & -- \\
\hline $27-28$ & -- & -- & -- & -- & -- & - & -- & -- & - & -- \\
\hline \multicolumn{11}{|l|}{ AUG } \\
\hline 14-14 & -- & -- & -- & -- & -- & -- & -- & -- & -- & $<.010$ \\
\hline $19-20$ & -- & -- & -- & 1 & -- & -- & 20 & -- & $<1$ & $<.010$ \\
\hline $23-23$ & -- & -- & -- & -- & - & -- & - & -- & -- & -- \\
\hline $24-24$ & -- & $<1$ & -- & -- & - & -- & -- & -- & -- & $<.010$ \\
\hline \multicolumn{11}{|l|}{ SEPT } \\
\hline $03-04$ & - & -- & -- & - & -- & -- & -- & -- & - & -- \\
\hline $14-14$ & -- & -- & -- & -- & -- & -. & -- & -- & -- & -- \\
\hline $15-15$ & -- & -- & -- & -- & -- & - & -- & -- & -- & $<.010$ \\
\hline \multicolumn{11}{|l|}{ OCT } \\
\hline $01-02$ & -- & -- & -- & 1 & -- & -- & 10 & -- & $<1$ & $<.010$ \\
\hline $03-03$ & -- & - & -- & -- & -- & -- & -- & -- & .. & -- \\
\hline $22-23$ & -. & $<1$ & -- & $<1$ & -- & $<1$ & 10 & -- & $<1$ & $<.010$ \\
\hline $29-29$ & -- & -- & -- & -- & -- & -- & -- & - & -- & - \\
\hline \multicolumn{11}{|l|}{ NOV } \\
\hline $05-05$ & -- & -- & -- & - & -. & -- & 30 & - & -- & - \\
\hline $09-10$ & -- & -- & -- & -- & -- & -- & -. & -- & -- & -- \\
\hline $11-12$ & $<10$ & 1 & $<0$ & $<6$ & 17 & $<1$ & 10 & $<4$ & $<1$ & -- \\
\hline $15-15$ & -- & -- & - & -- & -- & -- & -- & -- & -- & $\ldots$ \\
\hline $29-29$ & $<10$ & -- & 1 & -- & 23 & -- & 10 & $<4$ & -- & $<.010$ \\
\hline
\end{tabular}


Table 21. Physical data and chemical-constituent concentrations for storm-precipitation samples collected at Princeton, Massachusetts, September 1983 through April 1985--Continued

\begin{tabular}{|c|c|c|c|c|c|c|c|c|c|c|}
\hline Date & $\begin{array}{c}\text { Molyb- } \\
\text { denum, } \\
\text { dissolved } \\
(\mu \mathrm{g} / \mathrm{L})\end{array}$ & $\begin{array}{c}\text { Nickel, } \\
\text { dis- } \\
\text { solved } \\
(\mu \mathrm{g} / \mathrm{L})\end{array}$ & $\begin{array}{c}\text { Stron- } \\
\text { tium, } \\
\text { dis- } \\
\text { solved } \\
(\mu \mathrm{g} / \mathrm{L})\end{array}$ & $\begin{array}{c}\text { Vana- } \\
\text { dium, } \\
\text { dis- } \\
\text { solved } \\
(\mu \mathrm{g} / \mathrm{L})\end{array}$ & $\begin{array}{c}\text { Zinc, } \\
\text { dis- } \\
\text { solved } \\
(\mu \mathrm{g} / \mathrm{L})\end{array}$ & $\begin{array}{l}\text { Anti- } \\
\text { mony, } \\
\text { dis- } \\
\text { solved } \\
(\mu \mathrm{g} / \mathrm{L})\end{array}$ & $\begin{array}{l}\text { Alum- } \\
\text { inum, } \\
\text { dis- } \\
\text { solved } \\
(\mu \mathrm{g} / \mathrm{L})\end{array}$ & $\begin{array}{l}\text { 'Lith- } \\
\text { ium, } \\
\text { dis- } \\
\text { solved } \\
(\mu \mathrm{g} / \mathrm{L})\end{array}$ & $\begin{array}{c}\text { Sele- } \\
\text { nium, } \\
\text { dis } \\
\text { solved } \\
(\mu \mathrm{g} / \mathrm{L})\end{array}$ & $\begin{array}{c}\text { Bro- } \\
\text { mide, } \\
\text { dis- } \\
\text { solved } \\
(\mathrm{mg} / \mathrm{L})\end{array}$ \\
\hline \multicolumn{11}{|l|}{$\overline{\text { DEC } 1984}$} \\
\hline 03-03 & $<10$ & - & 1 & -- & 6 & -- & -- & $<4$ & -- & 0.10 \\
\hline $06-06$ & $<10$ & - & $<0$ & $<1$ & 22 & -- & -- & $<4$ & -- & $<.010$ \\
\hline $10-10$ & -- & - & .. & -- & -- & - & -- & -- & -- & - \\
\hline $19-19$ & $<10$ & - & $<0$ & -- & 19 & -- & -- & $<4$ & -- & .20 \\
\hline $21-22$ & $<10$ & - & $<0$ & $<1$ & 9 & + & $<10$ & $<4$ & $<1$ & $<.010$ \\
\hline $24-25$ & -- & - & -- & -- & -- & $\therefore$ & -- & -- & -. & -- \\
\hline $28-28$ & -- & - & -- & -- & -- & -- & -- & -- & -- & - \\
\hline \multicolumn{11}{|l|}{ JAN 1985} \\
\hline $01-02$ & $<10$ & _- & 1 & 1 & 13 & -- & -- & $<4$ & -- & .200 \\
\hline $07-08$ & $<10$ & - & 0 & -- & 23 & -- & ... & $<4$ & -- & - \\
\hline $17-17$ & .- & - & -- & -- & -- & -- & -- & -- & -- & - \\
\hline \multicolumn{11}{|l|}{ FEB } \\
\hline 01-03 & $<10$ & - & 1 & 1 & 20 & -- & -- & $<4$ & -- & $<.010$ \\
\hline $05-06$ & -- & - & -- & -- & -- & -- & -- & -- & -- & - \\
\hline $12-13$ & $<10$ & - & 1 & 1 & 12 & _- & $<10$ & $<4$ & $<1$ & .030 \\
\hline \multicolumn{11}{|l|}{ MAR } \\
\hline $04-05$ & $<10$ & -. & 1 & 2 & 110 & $<1$ & $<4$ & $<4$ & $<1$ & - \\
\hline $07-08$ & -- & -- & -- & -- & -- & -- & -- & --. & -- & - \\
\hline $11-12$ & $<10$ & - & $<0$ & $<1$ & 9 & $<1$ & $<10$ & $<4$ & $<1$ & .30 \\
\hline $17-18$ & -- & $\ldots$ & -- & -- & -- & _- & -- & -- & -- & -- \\
\hline $28-28$ & - & - & - & -- & - & -- & -. & -- & -- & - \\
\hline \multicolumn{11}{|l|}{ APR } \\
\hline 08-08 & $\therefore$ & $\ldots$ & -- & -- & -- & -- & -- & -. & -- & - \\
\hline $22-22$ & -- & - & -. & - & -- & -- & -- & -- & -- & $<.010$ \\
\hline $28-28$ & -- & -. & -- & -- & -- & -- & -- & - & -- & $\ldots$ \\
\hline \multicolumn{11}{|l|}{ SEPT } \\
\hline $26-27$ & $<10$ & -. & 1 & $<6$ & 4 & $<1$ & 20 & 9 & $<1$ & $<.010$ \\
\hline
\end{tabular}


Table 22. Physical data and chemical-constituent concentrations for storm-precipitation samples collected at Truro, Massachusetts, September 1983 through April 1985

[Collection site was located at the Cape Cod National Seashore Atlantic Coast Laboratory, latitude 41 ${ }^{\circ} 58^{\prime} 32^{\prime \prime}$, longitude $70^{\circ} 01^{\prime 2} 8^{\prime \prime}$. Storm type: CC, continental cyclone; CF, cold front; OC, oceanic cyclone; ND, storm type not determined. N, nitrogen; $\mathrm{P}$, phosphorus; $\mathrm{mm}$, millimeter; $\mathrm{h}$, hour; $\mu \mathrm{S} / \mathrm{cm}$, microsiemen per centimeter at 25 degrees Celsius; $\mathrm{mg} / \mathrm{L}$, milligram per liter; $\mu \mathrm{g} / \mathrm{L}$, microgram per liter; --, not measured; <, actual value is less than the detection limit for the constituent concentration]

\begin{tabular}{|c|c|c|c|c|c|c|c|c|c|c|}
\hline Date & $\begin{array}{c}\text { Storm } \\
\text { start } \\
\text { time } \\
\text { (h) }\end{array}$ & $\begin{array}{c}\text { Precip- } \\
\text { itation, } \\
\text { total } \\
(\mathrm{mm})\end{array}$ & $\begin{array}{c}\text { Storm } \\
\text { dura- } \\
\text { tion } \\
\text { (h) }\end{array}$ & $\begin{array}{l}\text { Storm } \\
\text { type }\end{array}$ & $\begin{array}{c}\text { Spe- } \\
\text { cific } \\
\text { conduct- } \\
\text { ance } \\
(\mu \mathrm{S} / \mathrm{cm})\end{array}$ & $\begin{array}{l}\mathbf{p H} \\
\text { (stand- } \\
\text { ard } \\
\text { units) }\end{array}$ & $\begin{array}{l}\text { Nitrogen, } \\
\text { ammonia, } \\
\text { dissolved } \\
(\mathrm{mg} / \mathrm{L} \\
\text { as } \mathrm{N})\end{array}$ & $\begin{array}{l}\text { Nitrogen, } \\
\text { nitrate, } \\
\text { dissolved } \\
\text { (mg/L } \\
\text { as } \mathrm{N} \text { ) }\end{array}$ & $\begin{array}{l}\text { Phos- } \\
\text { phorus, } \\
\text { dissolved } \\
\text { (mg/L } \\
\text { as P) }\end{array}$ & $\begin{array}{l}\text { Phos- } \\
\text { phorus, } \\
\text { ortho, } \\
\text { dissolved } \\
\text { (mg/L } \\
\text { as P) }\end{array}$ \\
\hline \multicolumn{11}{|l|}{ SEPT 1983} \\
\hline $17-17$ & 0100 & 39.9 & 11 & $\mathrm{CC}$ & 19 & 4.80 & -- & 0.080 & -- & $<0.060$ \\
\hline \multicolumn{11}{|l|}{ OCT } \\
\hline $01-02$ & 2300 & 22.9 & 15 & OC & 2 & 5.40 & -- & $<.050$ & -- & $<.060$ \\
\hline \multicolumn{11}{|l|}{ NOV } \\
\hline $21-21$ & 0600 & 21.3 & 6 & CF & 19 & 4.70 & 0.020 & .080 & 0.002 & .003 \\
\hline $28-29$ & 1400 & 14.5 & 17 & $\mathrm{CC}$ & 36 & 4.50 & $<.010$ & .110 & .001 & .011 \\
\hline \multicolumn{11}{|l|}{ DEC } \\
\hline $04-05$ & 1000 & 40.1 & 18 & OC & 64 & 4.80 & .110 & .060 & .001 & .006 \\
\hline $06-07$ & 1300 & 15.2 & 12 & $\mathrm{CC}$ & 20 & 4.50 & .050 & $<.050$ & .002 & .001 \\
\hline $15-15$ & 0200 & 10.9 & 16 & $\mathrm{CC}$ & 22 & 5.30 & .050 & .070 & .004 & $<.001$ \\
\hline $22-22$ & 0900 & 23.6 & 11 & $\mathrm{CC}$ & 43 & 4.90 & .060 & .070 & .002 & $<.001$ \\
\hline $24-24$ & 0700 & 7.62 & 7 & OC & 26 & 4.40 & .060 & .440 & -- & -- \\
\hline $28-28$ & 1300 & 15.2 & 8 & $\mathrm{CC}$ & 32 & 4.70 & .010 & .100 & .015 & $<.001$ \\
\hline \multicolumn{11}{|l|}{ JAN 1984} \\
\hline $06-06$ & 1900 & 5.84 & 5 & $\mathrm{CF}$ & 28 & 4.10 & -- & -- & -- & -- \\
\hline $10-11$ & 1800 & 34.3 & 16 & OC & 32 & 4.40 & .070 & .260 & .006 & $<.001$ \\
\hline $18-19$ & 1500 & 11.9 & 27 & OC & 63 & 3.70 & .338 & 1.06 & - & $<.060$ \\
\hline $24-25$ & 1500 & 9.65 & 21 & $\mathrm{CF}$ & 28 & 4.40 & $<.001$ & .280 & .002 & $<.001$ \\
\hline \multicolumn{11}{|l|}{ FEB } \\
\hline $15-17$ & 0100 & 34.3 & 59 & $\mathrm{OC}$ & 15 & 5.00 & .090 & .070 & $<.001$ & $<.001$ \\
\hline $24-24$ & 0100 & 20.3 & 5 & $\mathrm{OC}$ & 12 & 4.90 & .030 & .080 & .002 & $<.001$ \\
\hline $28-29$ & 1000 & 31.8 & 17 & $\mathrm{CC}$ & 38 & 5.10 & .080 & $<.050$ & $<.001$ & $<.001$ \\
\hline \multicolumn{11}{|l|}{ MAR } \\
\hline $13-14$ & 1100 & 16.8 & 17 & $\mathrm{OC}$ & 39 & 4.60 & .037 & .170 & -- & $<.060$ \\
\hline $17-20$ & 0100 & 69.6 & 82 & $\mathrm{CC}$ & 34 & 5.10 & $<.010$ & .050 & $<.001$ & .008 \\
\hline $21-22$ & 1900 & 6.35 & 13 & $\mathrm{CC}$ & -23 & 4.50 & .100 & .160 & -- & $<.060$ \\
\hline $29-31$ & 0000 & 64.3 & 51 & $\mathrm{OC}$ & 195 & 5.20 & $<.010$ & $<.050$ & $<.001$ & .011 \\
\hline \multicolumn{11}{|l|}{ APR } \\
\hline $05-05$ & 0100 & 20.1 & 23 & $\mathrm{CC}$ & 62 & 4.30 & .208 & .290 & -- & $<.060$ \\
\hline $15-16$ & 0600 & 59.9 & 38 & $\mathrm{CC}$ & 16 & 4.70 & .008 & .170 & -- & $<.060$ \\
\hline $19-19$ & 0000 & 7.62 & 15 & OC & 41 & 4.20 & .102 & .310 & -- & $<.060$ \\
\hline $23-25$ & 2000 & 24.1 & 45 & OC & 14 & 4.80 & .070 & .110 & $<.001$ & $<.001$ \\
\hline \multicolumn{11}{|l|}{ MAY } \\
\hline 03-04 & 2100 & 20.1 & 12 & ND & 30 & 4.40 & .440 & .340 & .005 & $<.001$ \\
\hline 08-09 & 1400 & 9.14 & 12 & $\mathrm{CC}$ & 31 & 4.40 & .670 & .320 & $<.001$ & $<.001$ \\
\hline $20-21$ & 2300 & 11.9 & 10 & $O C$ & 34 & 4.20 & .200 & .330 & $<.001$ & .005 \\
\hline $23-24$ & 2100 & 3.56 & 5 & CF & 24 & 4.30 & .066 & .400 & $<.001$ & $<.001$ \\
\hline $26-26$ & 2200 & 8.13 & 2 & CF & 38 & 4.10 & .313 & .470 & .050 & .002 \\
\hline $28-29$ & 1100 & 16.0 & 26 & ND & 30 & 4.30 & .160 & .310 & .014 & $<.001$ \\
\hline \multicolumn{11}{|l|}{ MAY 31- } \\
\hline JUNE 02 & 1400 & 59.9 & 45 & OC & 5 & 5.30 & .010 & .070 & .077 & .001 \\
\hline
\end{tabular}


Table 22. Physical data and chemical-constituent concentrations for storm-precipitation samples collected at Truro, Massachusetts, September 1983 through April 1985--Continued

\begin{tabular}{|c|c|c|c|c|c|c|c|c|c|c|}
\hline Date & $\begin{array}{c}\text { Storm } \\
\text { start } \\
\text { time } \\
\text { (h) }\end{array}$ & $\begin{array}{c}\text { Precip- } \\
\text { itation, } \\
\text { total } \\
(\mathrm{mm})\end{array}$ & $\begin{array}{c}\text { Storm } \\
\text { dura- } \\
\text { tion } \\
\text { (h) }\end{array}$ & $\begin{array}{l}\text { Storm } \\
\text { type }\end{array}$ & $\begin{array}{c}\text { Spe- } \\
\text { cific } \\
\text { conduct- } \\
\text { ance } \\
(\mu \mathrm{S} / \mathrm{cm})\end{array}$ & $\begin{array}{c}\mathrm{pH} \\
\text { (stand- } \\
\text { ard } \\
\text { units) }\end{array}$ & $\begin{array}{c}\text { Nitrogen, } \\
\text { ammonia, } \\
\text { dissolved. } \\
(\mathrm{mg} / \mathrm{L} \\
\text { as } \mathrm{N})\end{array}$ & $\begin{array}{c}\text { Nitrogen, } \\
\text { nitrate, } \\
\text { dissolved } \\
\text { (mg/L } \\
\text { as } \mathrm{N})\end{array}$ & $\begin{array}{l}\text { Phos- } \\
\text { phorus, } \\
\text { dissolved } \\
\text { (mg/L } \\
\text { as P) }\end{array}$ & $\begin{array}{l}\text { Phos- } \\
\text { phorus, } \\
\text { ortho, } \\
\text { dissolved } \\
\text { (mg/L } \\
\text { as } \mathrm{P} \text { ) }\end{array}$ \\
\hline \multicolumn{11}{|l|}{ JUNE 1984} \\
\hline 07-07 & 0600 & 6.35 & 1 & $\mathrm{CF}$ & 36 & 4.30 & -- & -- & -- & -- \\
\hline $18-19$ & 2300 & 15.2 & 14 & $\mathrm{CC}$ & 37 & 4.30 & 0.240 & 0.240 & $<0.001$ & $<0.001$ \\
\hline $24-26$ & 2000 & 94.7 & 37 & CF & 6 & 4.80 & .160 & .060 & $<.001$ & $<.001$ \\
\hline \multicolumn{11}{|l|}{ JULY } \\
\hline $07-08$ & 1100 & 68.3 & 24 & $\mathrm{CF}$ & 5 & 5.00 & $<.010$ & .070 & $<.001$ & $<.001$ \\
\hline $18-18$ & 1400 & 49.0 & 4 & CF & 7 & 4.80 & $<.010$ & .070 & .002 & $<.001$ \\
\hline $21-22$ & 1200 & 11.4 & 22 & $\mathrm{CF}$ & 10 & 4.70 & $<.010$ & .140 & $<.001$ & $<.001$ \\
\hline $27-27$ & 0900 & 29.0 & 9 & OC & 23 & 4.60 & .030 & .150 & $<.001$ & $<.001$ \\
\hline \multicolumn{11}{|l|}{ AUG } \\
\hline $07-07$ & 1600 & 1.52 & 4 & $\mathrm{CF}$ & 128 & 3.60 & -- & -- & -- & -- \\
\hline \multicolumn{11}{|l|}{ SEPT } \\
\hline 03-04 & 0400 & 15.5 . & 29 & OC & 33 & 4.20 & .140 & .340 & $<.001$ & -- \\
\hline $12-12$ & 0600 & 3.30 & 3 & $\mathrm{CF}$ & 37 & 4.10 & .165 & .440 & -- & -- \\
\hline $14-15$ & 1700 & 62.0 & 28 & OC & 43 & 4.20 & .260 & .490 & $<.001$ & .002 \\
\hline \multicolumn{11}{|l|}{ OCT } \\
\hline $01-02$ & 1200 & 76.7 & 25 & OC & 31 & 5.20 & .060 & .030 & $<.001$ & $<.001$ \\
\hline $23-23$ & 0100 & 15.2 & 4 & $\mathrm{CF}$ & 14 & 4.50 & .150 & .140 & $<.001$ & .002 \\
\hline $24-24$ & 0200 & 3.56 & 8 & ND & 37 & 3.96 & -- & $\ldots$ & -- & -- \\
\hline $29-29$ & 0200 & 22.6 & 16 & $\mathrm{CF}$ & 27 & 4.20 & .300 & .600 & $<.001$ & .002 \\
\hline \multicolumn{11}{|l|}{ NOV } \\
\hline $11-12$ & 1100 & 13.5 & 23 & $\mathrm{CF}$ & 6 & 5.03 & $<.001$ & -- & $<.001$ & .017 \\
\hline $13-14$ & 2000 & 8.64 & 18 & OC & 41 & 4.22 & 1.00 & 1.00 & .095 & .054 \\
\hline $16-16$ & 0000 & 3.56 & 8 & CF & 31 & 4.27 & -- & -- & - & -- \\
\hline $29-29$ & 0600 & 10.4 & 4 & $\mathrm{CF}$ & 11 & 5.00 & .004 & -- & -- & -- \\
\hline \multicolumn{11}{|l|}{ DEC } \\
\hline 03-03 & 1200 & 5.33 & 7 & $\mathrm{CC}$ & 38 & 4.39 & -- & -- & -- & -- \\
\hline $06-06$ & 0100 & 22.9 & 10 & $\mathrm{CC}$ & 48 & 4.83 & .048 & .080 & $<.001$ & $<.001$ \\
\hline $10-10$ & 1000 & 3.81 & 14 & ND & 25 & 4.32 & -- & -- & -- & -- \\
\hline $15-15$ & 0900 & 3.81 & 9 & ND & 58 & 3.91 & -- & -- & - & -- \\
\hline $19-19$ & 1500 & 8.38 & 6 & $\mathrm{CC}$ & 34 & 4.10 & .202 & .430 & -- & -- \\
\hline $21-22$ & 2100 & 23.4 & 11 & $\mathrm{CC}$ & 51 & 4.17 & .154 & .270 & $<.001$ & $<.001$ \\
\hline $24-25$ & 1800 & 4.06 & 11 & $\mathrm{CC}$ & 15 & 4.58 & -- & -- & -- & -- \\
\hline $28-28$ & 0000 & 5.33 & 19 & ND & 30 & 4.20 & .061 & .300 & -- & -- \\
\hline \multicolumn{11}{|l|}{ JAN 1985} \\
\hline $02-02$ & 1200 & 5.08 & 11 & $\mathrm{CF}$ & 45 & 3.98 & .204 & .770 & -- & -- \\
\hline $07-08$ & 1900 & 12.4 & 17 & $\mathrm{CF}$ & 36 & 4.41 & -- & -- & -- & -- \\
\hline $17-18$ & 1200 & 4.32 & 17 & OC & 99 & 4.07 & -- & -- & -- & -- \\
\hline \multicolumn{11}{|l|}{ JAN 31- } \\
\hline FEB 03 & 1700 & 14.0 & 63 & $\mathrm{CF}$ & 25 & 4.29 & .070 & .270 & -- & -- \\
\hline \multicolumn{11}{|l|}{ FEB } \\
\hline $05-07$ & 2000 & 19.6 & 31 & OC & 16 & 4.54 & .075 & .170 & -- & $<.010$ \\
\hline $12-13$ & 1600 & 19.1 & 22 & $\mathrm{CC}$ & 58 & 4.55 & .032 & $<.010$ & .006 & .021 \\
\hline $23-23$ & 1400 & .76 & 5 & CF & 47 & 3.95 & -- & -- & -- & .- \\
\hline \multicolumn{11}{|l|}{ MAR } \\
\hline $02-02$ & 0600 & 7.87 & 6 & OC & 12 & 4.61 & -- & -. & -- & -- \\
\hline $04-05$ & 2200 & 14.2 & 10 & $\mathrm{CC}$ & 69 & 4.07 & .228 & .040 & -- & $<.010$ \\
\hline
\end{tabular}


Table 22. Physical data and chemical-constituent concentrations for storm-precipitation samples collected at Truro, Massachusetts, September 1983 through April 1985--Continued

\begin{tabular}{|c|c|c|c|c|c|c|c|c|c|c|}
\hline Date & $\begin{array}{l}\text { Storm } \\
\text { start } \\
\text { time } \\
\text { (h) }\end{array}$ & $\begin{array}{l}\text { Precip- } \\
\text { itation, } \\
\text { total } \\
\text { (mm) }\end{array}$ & $\begin{array}{l}\text { Storm } \\
\text { dura- } \\
\text { tion } \\
\text { (h) }\end{array}$ & $\begin{array}{c}\text { Storm } \\
\text { type }\end{array}$ & $\begin{array}{c}\text { Spe- } \\
\text { cific } \\
\text { conduct- } \\
\text { ance } \\
(\mu \mathrm{S} / \mathrm{cm})\end{array}$ & $\begin{array}{c}\text { pH } \\
\text { (stand- } \\
\text { ard } \\
\text { units) }\end{array}$ & $\begin{array}{l}\text { Nitrogen, } \\
\text { ammonia, } \\
\text { dissolved } \\
(\mathrm{mg} / \mathrm{L} \\
\text { as } \mathrm{N})\end{array}$ & $\begin{array}{l}\text { Nitrogen, } \\
\text { nitrate, } \\
\text { dissolved } \\
\text { (mg/L } \\
\text { as } \mathrm{N})\end{array}$ & $\begin{array}{l}\text { Phos- } \\
\text { phorus, } \\
\text { dissolved } \\
\text { (mg/L } \\
\text { as P) }\end{array}$ & $\begin{array}{l}\text { Phos- } \\
\text { phorus, } \\
\text { ortho, } \\
\text { dissolved } \\
\text { (mg/L } \\
\text { as P) }\end{array}$ \\
\hline \multicolumn{11}{|c|}{ MAR 1985--Continued } \\
\hline $08-08$ & 0001 & 6.35 & 9 & ND & 29 & 4.17 & -- & -- & -- & - \\
\hline $12-12$ & 0200 & 42.7 & $\cdot 15$ & $\mathrm{CC}$ & 20 & 4.46 & 0.066 & 0.310 & $<0.001$ & 0.002 \\
\hline $17-18$ & 1300 & 11.9 & 34 & OC & 61 & 4.04 & -- & -- & -- & - \\
\hline \multicolumn{11}{|l|}{ MAR 17- } \\
\hline APR 01 & 1700 & 11.2 & 31 & $\mathrm{OC}$ & 45 & 4.53 & -- & -- & -- & -- \\
\hline \multicolumn{11}{|l|}{ APR } \\
\hline $08-08$ & 0000 & 14.7 & 9 & $\mathrm{OC}$ & 26 & 4.48 & -- & - & -- & -- \\
\hline Date & $\begin{array}{l}\text { Carbon, } \\
\text { organic, } \\
\text { total } \\
(\mathrm{mg} / \mathrm{L})\end{array}$ & $\begin{array}{l}\text { Calcium, } \\
\text { dis- } \\
\text { solved } \\
(\mathrm{mg} / \mathrm{L})\end{array}$ & $\begin{array}{l}\text { Magne- } \\
\text { sium, } \\
\text { dis- } \\
\text { solved } \\
(\mathrm{mg} / \mathrm{L})\end{array}$ & $\begin{array}{l}\text { Sodium, } \\
\text { dis- } \\
\text { solved } \\
(\mathrm{mg} / \mathrm{L})\end{array}$ & $\begin{array}{l}\text { Potas- } \\
\text { sium, } \\
\text { dissolved } \\
(\mathrm{mg} / \mathrm{L})\end{array}$ & $\begin{array}{c}\text { Chloride, } \\
\text { dissolved } \\
(\mathrm{mg} / \mathrm{L})\end{array}$ & $\begin{array}{c}\text { Sulfate, } \\
\text { dissolved } \\
\text { (mg/L) }\end{array}$ & $\begin{array}{c}\text { Fluoride, } \\
\text { dissolved } \\
(\mathrm{mg} / \mathrm{L})\end{array}$ & $\begin{array}{l}\text { Silica, } \\
\text { dissolved } \\
(\mathrm{mg} / \mathrm{L})\end{array}$ & $\begin{array}{c}\text { Arsenic, } \\
\text { dissolved } \\
(\mu \mathrm{g} / \mathrm{L})\end{array}$ \\
\hline \multicolumn{11}{|l|}{$\overline{\text { SEPT } 1983}$} \\
\hline $17-17$ & -- & 0.06 & 0.17 & 1.6 & 0.06 & 3.33 & 1.22 & $<0.01$ & $<0.01$ & -- \\
\hline \multicolumn{11}{|l|}{ OCT } \\
\hline $01-02$ & - & .04 & .01 & .13 & .01 & $<.20$ & .21 & $<.01$ & $<.01$ & -- \\
\hline \multicolumn{11}{|l|}{ NOV } \\
\hline $21-21$ & - & .11 & .19 & 1.6 & .05 & 2.92 & 1.19 & $<.01$ & $<.01$ & -- \\
\hline $28-29$ & $\cdots$ & .16 & .28 & 2.9 & .10 & 5.83 & 1.98 & $<.01$ & $<.01$ & -- \\
\hline \multicolumn{11}{|l|}{$\mathrm{DEC}$} \\
\hline $06-07$ & - & .37 & 1.0 & 9.1 & .30 & 20.1 & 2.89 & .06 & $<.01$ & 1 \\
\hline $15-15$ & -- & .09 & .17 & 1.5 & .06 & 2.76 & 1.38 & $<.01$ & $<.01$ & -- \\
\hline $22-22$ & - & .14 & .11 & 1.2 & .06 & 2.23 & .79 & $<.01$ & $<.01$ & -- \\
\hline $24-24$ & -- & .23 & .61 & 5.4 & .21 & 11.6 & 1.91 & $<.01$ & $<.01$ & -- \\
\hline $28-28$ & $-\cdots$ & .10 & .15 & 1.3 & .09 & 2.25 & .80 & $<.01$ & $<.01$ & -- \\
\hline JAN 1984 & -- & .18 & .45 & 3.2 & .14 & 7.48 & 1.34 & $<.01$ & $<.01$ & - \\
\hline $06-06$ & -- & -- & -- & -- & -- & -- & -- & - & -- & -- \\
\hline $10-11$ & -- & .12 & .25 & 2.5 & .11 & 5.42 & 1.90 & $<.01$ & $<.01$ & -- \\
\hline $18-19$ & -- & .008 & .11 & 1.0 & .09 & 1.70 & 5.87 & $<.01$ & -- & -- \\
\hline $24-25$ & -- & .08 & .20 & 1.6 & .06 & 3.39 & 1.74 & $<.01$ & -- & -- \\
\hline \multicolumn{11}{|l|}{ FEB } \\
\hline $15-17$ & -- & .10 & .19 & 1.7 & .07 & 3.41 & .77 & .02 & $<.01$ & -- \\
\hline $24-24$ & -- & .06 & .06 & 1.0 & .06 & 1.87 & .69 & $<.01$ & $<.01$ & -- \\
\hline $28-29$ & -- & .27 & .69 & 5.4 & .22 & 11.5 & 1.70 & .02 & $<.01$ & -- \\
\hline \multicolumn{11}{|l|}{ MAR } \\
\hline $13-14$ & -- & .22 & .62 & 5.3 & .22 & 11.9 & 2.46 & $<.01$ & -- & -- \\
\hline $17-20$ & -- & .34 & .59 & 4.6 & .19 & 9.79 & 1.57 & $<.01$ & $<.01$ & $<1$ \\
\hline $21-22$ & -- & .15 & .22 & 1.9 & .09 & 4.10 & 1.83 & $<.01$ & - & -- \\
\hline $29-31$ & -- & 1.2 & 3.4 & 28 & 1.1 & 52.3 & 8.41 & $<.01$ & $<.01$ & $<1$ \\
\hline \multicolumn{11}{|l|}{ APR } \\
\hline $05-05$ & -- & .30 & .70 & 6.0 & .28 & 10.3 & 4.05 & $<.01$ & -- & 1 \\
\hline $15-16$ & - & .12 & .11 & .90 & .06 & 1.58 & 1.02 & $<.01$ & $<.01$ & $<1$ \\
\hline $19-19$ & -- & .13 & .17 & 1.4 & .19 & 2.34 & 2.97 & .03 & -- & -- \\
\hline $23-25$ & -- & .16 & .10 & .70 & .05 & 1.17 & .98 & .03 & -- & $<1$ \\
\hline
\end{tabular}


Table 22. Physical data and chemical-constituent concentrations for storm-precipitation samples collected at Truro, Massachusetts, September 1983 through April 1985--Continued

\begin{tabular}{|c|c|c|c|c|c|c|c|c|c|c|}
\hline Date & $\begin{array}{c}\text { Carbon, } \\
\text { organic, } \\
\text { total } \\
(\mathrm{mg} / \mathrm{L})\end{array}$ & $\begin{array}{l}\text { Calcium, } \\
\text { dis- } \\
\text { solved } \\
(\mathrm{mg} / \mathrm{L})\end{array}$ & $\begin{array}{c}\text { Magne- } \\
\text { sium, } \\
\text { dis- } \\
\text { solved } \\
(\mathrm{mg} / \mathrm{L})\end{array}$ & $\begin{array}{l}\text { Sodium; } \\
\text { dis- } \\
\text { solved } \\
(\mathrm{mg} / \mathrm{L})\end{array}$ & $\begin{array}{l}\text { Potas- } \\
\text { sium, } \\
\text { dissolved } \\
(\mathrm{mg} / \mathrm{L})\end{array}$ & $\begin{array}{l}\text { Chloride, } \\
\text { dissolved } \\
(\mathrm{mg} / \mathrm{L})\end{array}$ & $\begin{array}{c}\text { Sulfate, } \\
\text { dissolved } \\
(\mathrm{mg} / \mathrm{L})\end{array}$ & $\begin{array}{c}\text { Fluoride, } \\
\text { dissolved } \\
(\mathrm{mg} / \mathrm{L})\end{array}$ & $\begin{array}{c}\text { Silica, } \\
\text { dissolved } \\
\text { (mg/L) }\end{array}$ & $\begin{array}{c}\text { Arsenic, } \\
\text { dissolved } \\
(\mu \mathrm{g} / \mathrm{L})\end{array}$ \\
\hline \multicolumn{11}{|l|}{ MAY 1984} \\
\hline 03-04 & -- & 0.27 & 0.16 & 0.80 & 0.07 & 1.54 & 2.33 & $<0.01$ & -- & $<1$ \\
\hline 08-09 & -- & .11 & .08 & .70 & .07 & 1.16 & 2.30 & $<.01$ & -- & $<1$ \\
\hline $20-21$ & -- & .04 & $<.01$ & $<.20$ & .02 & $<.20$ & 2.56 & $<.01$ & -- & -. \\
\hline $23-24$ & -- & .10 & .04 & .28 & .06 & .46 & 1.44 & $<.01$ & -- & -- \\
\hline $26-26$ & -- & .07 & .02 & .12 & .06 & .23 & 2.98 & $<.01$ & -- & -- \\
\hline $28-29$ & -- & .09 & .13 & .70 & .05 & 1.28 & 1.93 & $<.01$ & -- & 1. \\
\hline \multicolumn{11}{|l|}{ MAY 31- } \\
\hline JUNE 02 & -- & .05 & .09 & .70 & .03 & 1.18 & .38 & $<.01$ & -- & 1 \\
\hline \multicolumn{11}{|l|}{ JUNE } \\
\hline $07-07$ & -. & -- & -. & -- & -- & -- & -- & -- & -- & .. \\
\hline $18-19$ & -- & .12 & .20 & 1.8 & .13 & 3.28 & 2.46 & .02 & -- & - \\
\hline $24-26$ & -- & .05 & .03 & .40 & .03 & .63 & .42 & .03 & -- & $<1$ \\
\hline \multicolumn{11}{|l|}{ JULY } \\
\hline $07-08$ & -- & .04 & .08 & .30 & .03 & .47 & .35 & $<.01$ & -. & 1 \\
\hline $18-18$ & -- & .03 & .04 & .30 & .03 & .42 & .62 & $<.01$ & -- & 1 \\
\hline $21-22$ & -- & .22 & .06 & .40 & .05 & .48 & .80 & $<.01$ & -- & -- \\
\hline $27-27$ & -. & .08 & .24 & 1.6 & .06 & 3.06 & 1.20 & $<.01$ & -- & -- \\
\hline AUG & & & & & & & 20 & & & \\
\hline 07-07. & -- & -- & -- & -- & -- & -- & -- & -- & -- & -- \\
\hline \multicolumn{11}{|l|}{ SEPT } \\
\hline 03-04 & -- & .06 & .07 & .60 & .08 & 1.07 & 3.04 & .03 & -- & -- \\
\hline $12-12$ & - & .17 & .07 & .44 & .10 & .90 & 3.10 & .03 & -- & - \\
\hline $14-15$ & -- & .07 & .13 & .60 & .03 & 1.20 & 3.20 & $<.01$ & .. & $<1$ \\
\hline \multicolumn{11}{|l|}{ OCT } \\
\hline 01-02 & -- & .19 & .64 & 4.8 & .. & 8.70 & 1.40 & $<.01$ & -- & $<1$ \\
\hline $23-23$ & - & .11 & $<.01$ & .50 & $<.01$ & .51 & .92 & $<.01$ & $<0.01$ & $<1$ \\
\hline $24-24$ & -- & -- & -- & -- & -- & -- & -. & -- & -- & -- \\
\hline $29-29$ & -- & .08 & .02 & .30 & .05 & .29 & 2.00 & $<.01$ & .02 & $<1$ \\
\hline \multicolumn{11}{|l|}{ NOV } \\
\hline $11-12$ & -- & .03 & .06 & -- & -. & 1.10 & .30 & -- & $<.01$ & -- \\
\hline $13-14$ & -- & .23 & .32 & 3.1 & .48 & 5.90 & 2.40 & .01 & .03 & -- \\
\hline \multicolumn{11}{|l|}{ NOV } \\
\hline $16-16$ & - & -- & -- & -- & -- & -- & -- & - & -- & -- \\
\hline \multicolumn{11}{|l|}{ NOV } \\
\hline $29-29$ & -- & .13 & .12 & .05 & .06 & 1.80 & .50 & -- & .02 & -- \\
\hline \multicolumn{11}{|l|}{ DEC } \\
\hline $03-03$ & -- & -- & -- & -- & -- & -. & .. & -- & -- & -- \\
\hline 06-06 & ..- & .07 & .74 & 5.7 & .24 & 11.0 & 2.10 & .01 & .01 & $<1$ \\
\hline $10-10$ & -- & -- & - & -- & -. & -- & -- & -- & -- & -- \\
\hline $15-15$ & -- & -- & -- & -- & -- & -- & -- & -- & -- & -- \\
\hline $19-19$ & -- & .12 & .05 & .35 & .06 & .55 & 1.90 & .01 & .02 & -- \\
\hline $21-22$ & -- & .19 & .46 & 3.6 & .18 & 9.10 & 3.10 & .01 & $<.01$ & $<1$ \\
\hline $24-25$ & - & -- & -- & -- & -- & -- & -- & $\ldots$ & -- & -- \\
\hline $28-28$ & -- & .10 & .05 & .32 & .05 & .50 & 2.10 & .05 & -- & -- \\
\hline \multicolumn{11}{|l|}{ JAN 1985} \\
\hline $02-02$ & -- & .11 & .10 & .60 & .05 & .92 & 2.60 & .02 & -- & -- \\
\hline $07-08$ & & -- & -- & -- &.- & $\ldots$ & - & -- & -- & --- \\
\hline $17-18$ & -- & - & -- & -- & -- & -- & $\ldots$ & -- & -. & ... \\
\hline
\end{tabular}


Table 22. Physical data and chemical-constituent concentrations for storm-precipitation samples collected at Truro, Massachusetts, September 1983 through April 1985--Continued

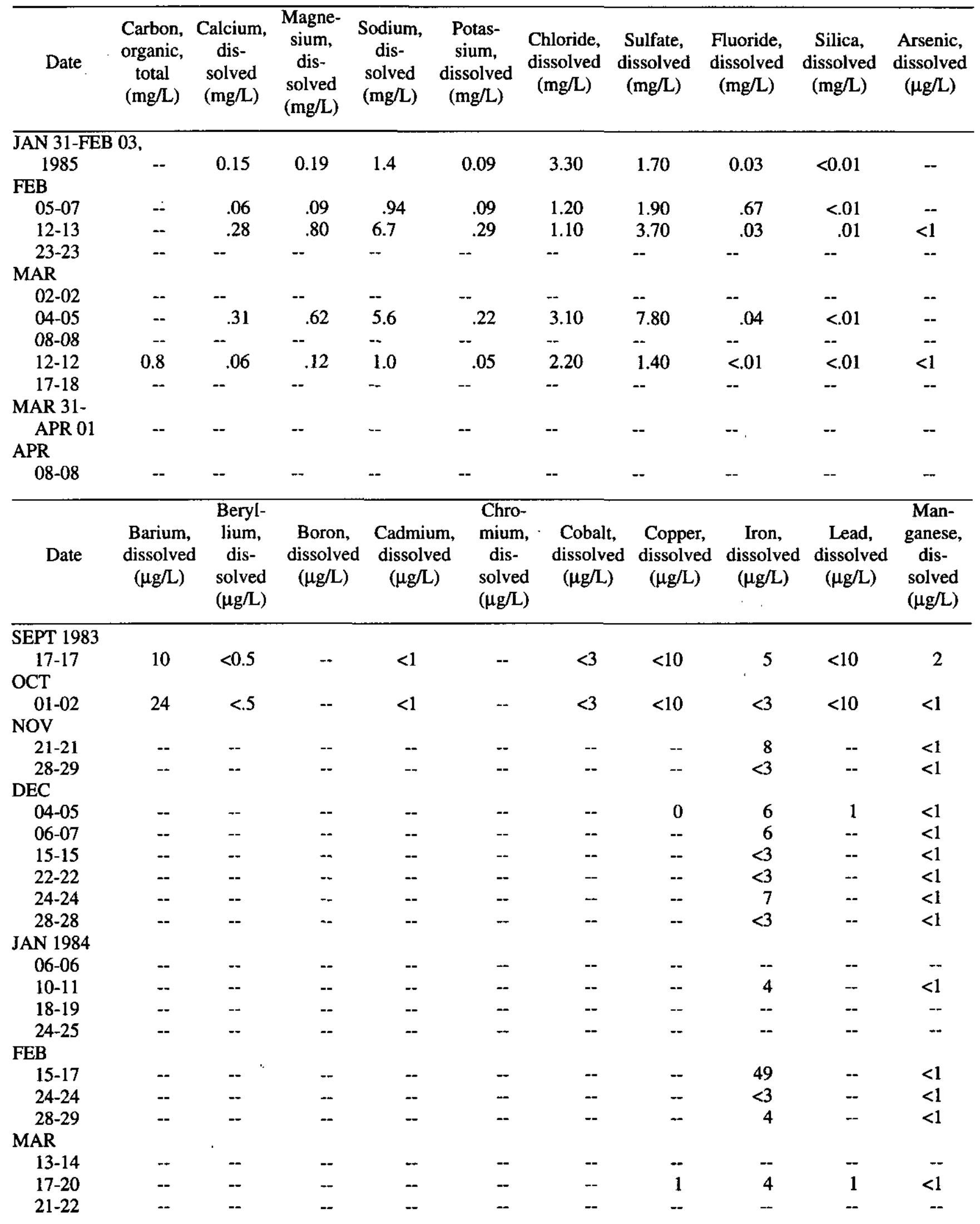


Table 22. Physical data and chemical-constituent concentrations for storm-precipitation samples collected at Truro, Massachusetts, September 1983 through April 1985--Continued

\begin{tabular}{|c|c|c|c|c|c|c|c|c|c|c|}
\hline Date & $\begin{array}{c}\text { Barium, } \\
\text { dissolved } \\
(\mu \mathrm{g} / \mathrm{L})\end{array}$ & $\begin{array}{l}\text { Beryl- } \\
\text { lium, } \\
\text { dis- } \\
\text { solved } \\
(\mu \mathrm{g} / \mathrm{L})\end{array}$ & $\begin{array}{c}\text { Boron, } \\
\text { dissolved } \\
(\mu g / L)\end{array}$ & $\begin{array}{c}\text { Cadmium, } \\
\text { dissolved } \\
(\mu \mathrm{g} / \mathrm{L})\end{array}$ & $\begin{array}{l}\text { Chro- }= \\
\text { mium, } \\
\text { dis- } \\
\text { solved } \\
(\mu \mathrm{g} / \mathrm{L})\end{array}$ & $\begin{array}{l}\text { Cobalt, } \\
\text { dissolved } \\
(\mu \mathrm{g} / \mathrm{L})\end{array}$ & $\begin{array}{l}\text { Copper, } \\
\text { dissolved } \\
(\mu g / L)\end{array}$ & $\begin{array}{l}\text { Iron, } \\
\text { dissolved } \\
(\mu \mathrm{g} / \mathrm{L})\end{array}$ & $\begin{array}{l}\mathrm{n} \\
\text { Lead, } \\
\text { dissolved } \\
(\mu \mathrm{g} / \mathrm{L})\end{array}$ & $\begin{array}{c}\text { Man- } \\
\text { ganese, } \\
\text { dis- } \\
\text { solved } \\
(\mu \mathrm{g} / \mathrm{L})\end{array}$ \\
\hline \multicolumn{11}{|c|}{ MAR 1984--Continued } \\
\hline $29-31$ & -- & -- & -- & -- & -- & $\cdots$ & 3 & 7 & 1 & 2 \\
\hline \multicolumn{11}{|l|}{ APR } \\
\hline $05-05$ & -- & -- & -- & -- & -- & -- & 3 & -- & 4 & -- \\
\hline $15-16$ & -- & -- & -- & -- & -- & -- & 2 & 38 & 2 & $<1$ \\
\hline $19-19$ & -- & -- & -- & -- & -- & - & -- & -- & -- & -- \\
\hline $23-25$ & -- & -- & -- & - & -- & -- & 2 & $<3$ & 1 & 1 \\
\hline \multicolumn{11}{|l|}{ MAY } \\
\hline 03-04 & -- & -- & -- & -- & -- & - & 1 & 8 & 4 & 4 \\
\hline 08-09 & -- & -- & -- & -- & -- & -- & 3. & 15 & 2 & 2 \\
\hline $20-21$ & -- & -- & -- & -- & -- & -- & -- & $<3$ & -- & $<1$ \\
\hline $23-24$ & -- & -- & -- & -- & -- & -- & -- & $<3$ & -- & $<1$ \\
\hline $26-26$ & -- & -- & -- & -- & -- & -- & -- & $<3$ & -- & 2 \\
\hline $28-29$ & -- & -- & -- & -- & -. & -- & 6 & 7 & 3 & 1 \\
\hline \multicolumn{11}{|l|}{ MAY 31- } \\
\hline JUNE 02 & -- & -- & -- & -- & -- & -- & 1 & 7 & 0 & $<1$ \\
\hline \multicolumn{11}{|l|}{ JUNE } \\
\hline $07-07$ & -- & -- & -- & -- & -- & -- & -- & -- & -- & -- \\
\hline $18-19$ & -. & -- & -- & -- & -- & -- & -- & 6 & -- & 2 \\
\hline $24-26$ & -- & -- & -- & - & -- & -- & 1 & $<3$ & 1 & $<1$ \\
\hline \multicolumn{11}{|l|}{ JULY } \\
\hline 07-08 & -- & -- & -- & -- & -- & -- & 1 & 4 & 0 & $<1$ \\
\hline $18-18$ & -. & -- & -- & -- & -- & -- & 1 & 4 & 1 & $<1$ \\
\hline $21-21$ & -- & -- & -- & -- & -- & -- & -- & 4 & -- & 3 \\
\hline $27-27$ & $\therefore$ & -- & -- & -- & -- & -- & -- & 4 & -- & $<1$ \\
\hline \multicolumn{11}{|l|}{ AUG } \\
\hline $07-07$ & -- & -- & $\cdot-$ & -- & -- & -- & - & -- & -- & -- \\
\hline \multicolumn{11}{|l|}{ SEPT } \\
\hline 03-04 & -- & -- & -- & -- & -- & -- & -- & 5 & 5 & 1 \\
\hline $12-12$ & -- & -- & -- & -- & -- & -- & -- & -- & -- & -- \\
\hline $14-15$ & -- & -- & -- & -- & -- & -. & 2 & 5 & 6 & 1 \\
\hline \multicolumn{11}{|l|}{ OCT } \\
\hline $01-02$ & - & -- & - & -- & -- & -- & 0 & 5 & 0 & $<1$ \\
\hline $23-23$ & -- & -- & -- & -- & -- & -- & 4 & $<3$ & 1 & $<1$ \\
\hline $24-24$ & -- & -- & -- & -- & - & -- & -- & -. & -- & -- \\
\hline $29-29$ & -- & -- & $<20$ & - & -- & -- & - & 5 & 6 & 2 \\
\hline \multicolumn{11}{|l|}{ NOV } \\
\hline $11-12$ & 11 & -- & $<20$ & $<1$ & -- & $<3$ & 1 & $<3$ & $<10$ & $<1$ \\
\hline $13-14$ & 13 & - & $<20$ & 3 & -- & $<3$ & $<10$ & 14 & -- & 2 \\
\hline $16-16$ & -- & -- & -- & -- & -- & - & -- & -- & - & -- \\
\hline $29-29$ & $<2$ & -- & $<20$ & $<1$ & -- & $<3$ & -- & $<3$ & - & $<1$ \\
\hline \multicolumn{11}{|l|}{ DEC } \\
\hline 03-03 & -- & -- & -- & $\therefore$ & -- & -- & -- & -- & -- & -- \\
\hline $06-06$ & 11 & $<0.5$ & $<20$ & 1 & .. & $<3$ & - & $<3$ & 0 & $<1$ \\
\hline $10-10$ & -- & -- & -- & -- & - & -- & 3 & -- & -- & -. \\
\hline $15-15$ & -- & - & -- & -- & -- & -- & -- & -- & -- & -- \\
\hline $19-19$ & 13 & $<.5$ & $<20$ & $<1$ & -- & $<3$ & - & 5 & -- & $<1$ \\
\hline $21-22$ & 13 & $<.5$ & $<20$ & $<1$ & -- & $<3$ & 2 & 5 & -- & 1 \\
\hline $24-25$ & -- & -- & -- & -- & -- & -- & -- & -- & -- & -- \\
\hline
\end{tabular}


Table 22. Physical data and chemical-constituent concentrations for storm-precipitation samples collected at Truro. Massachusetts, September 1983 through April 1985--Continued

\begin{tabular}{|c|c|c|c|c|c|c|c|c|c|c|}
\hline Date & $\begin{array}{c}\text { Barium, } \\
\text { dissolved } \\
(\mu \mathrm{g} / \mathrm{L})\end{array}$ & $\begin{array}{l}\text { Beryl- } \\
\text { lium, } \\
\text { dis- } \\
\text { solved } \\
(\mu \mathrm{g} / \mathrm{L})\end{array}$ & $\begin{array}{c}\text { Boron, } \\
\text { dissolved } \\
(\mu \mathrm{g} / \mathrm{L})\end{array}$ & $\begin{array}{c}\text { Cadmium, } \\
\text { dissolved } \\
(\mu \mathrm{g} / \mathrm{L})\end{array}$ & $\begin{array}{l}\text { Chro- } \\
\text { mium, } \\
\text { dis- } \\
\text { solved } \\
(\mu \mathrm{g} / \mathrm{L})\end{array}$ & $\begin{array}{c}\text { Cobalt, } \\
\text { dissolved } \\
(\mu \mathrm{g} / \mathrm{L})\end{array}$ & $\begin{array}{c}\text { Copper, } \\
\text { dissolved } \\
(\mu \mathrm{g} / \mathrm{L})\end{array}$ & $\begin{array}{c}\text { Iron, } \\
\text { dissolved } \\
(\mu \mathrm{g} / \mathrm{L})\end{array}$ & $\begin{array}{c}\text { Lead, } \\
\text { dissolved } \\
(\mu \mathrm{g} / \mathrm{L})\end{array}$ & $\begin{array}{c}\text { Man- } \\
\text { ganese, } \\
\text { dis- } \\
\text { solved } \\
(\mu \mathrm{g} / \mathrm{L})\end{array}$ \\
\hline \multicolumn{11}{|c|}{ DEC 1984--Continued } \\
\hline $\begin{array}{c}28-28 \\
\text { JAN } 1985\end{array}$ & -- & -- & $<20$ & - & -. & $\cdots$ & -. & + & -- & -- \\
\hline $02-02$ & -- & -- & $<20$ & -- & -- & -. & -- & -- & -- & -- \\
\hline 07-08 & -- & -- & -- & -- & -- & -- & -- & -- & -- & -- \\
\hline $17-18$ & -- & -- & -- & -- & -- & -- & -- & -- & -- & - \\
\hline \multicolumn{11}{|l|}{ JAN 31- } \\
\hline FEB 03 & 11 & $<0.5$ & 20 & $<1$ & -- & $<3$ & -- & 69 & - & $<1$ \\
\hline \multicolumn{11}{|l|}{ FEB } \\
\hline 05-07 & 12 & $<.5$ & $<20$ & $<1$ & -- & $<3$ & -- & 3 & -- & $<1$ \\
\hline $12-13$ & 14 & $<.5$ & $<20$ & $<1$ & -- & $<3$ & 2 & 5 & 1 & 1 \\
\hline $23-23$ & -- & -- & -- & -- & -- & -- & - & - & -- & -- \\
\hline \multicolumn{11}{|l|}{ MAR } \\
\hline $02-02$ & -- & -- & -- & -- & -- & -- & -- & -- & -- & -- \\
\hline 04-05 & 12 & $<.5$ & $<20$ & $<1$ & -- & $<3$ & -- & 5 & -- & 1 \\
\hline $08-08$ & -- & -- & -- & -- & -- & -- & -- & -- & -- & -- \\
\hline $12-12$ & 4 & $<.5$ & $<20$ & $<1$ & $<1$ & $<3$ & 3 & $<3$ & 2 & $<1$ \\
\hline $17-18$ & -- & -- & -- & -- & -- & -- & -- & -- & -- & -- \\
\hline \multicolumn{11}{|l|}{ MAR 31- } \\
\hline APR 01 & - & -- & -- & -- & -- & -- & - & - & -- & -- \\
\hline \multicolumn{11}{|l|}{ APR } \\
\hline $08-08$ & - & -- & - & - & $\cdots$ & - & - & - & - & -- \\
\hline Date & $\begin{array}{c}\text { Molyb- } \\
\text { denum, } \\
\text { dissolved } \\
(\mu \mathrm{g} / \mathrm{L})\end{array}$ & $\begin{array}{c}\text { Nickel, } \\
\text { dis- } \\
\text { solved } \\
(\mu \mathrm{g} / \mathrm{L})\end{array}$ & $\begin{array}{l}\text { Stron- } \\
\text { tium, } \\
\text { dis- } \\
\text { solved } \\
(\mu \mathrm{g} / \mathrm{L})\end{array}$ & $\begin{array}{c}\text { Vana- } \\
\text { dium, } \\
\text { dis- } \\
\text { solved } \\
(\mu \mathrm{g} / \mathrm{L})\end{array}$ & $\begin{array}{l}\text { Zinc, } \\
\text { dis- } \\
\text { solved } \\
(\mu \mathrm{g} / \mathrm{L})\end{array}$ & $\begin{array}{c}\text { Anti- } \\
\text { mony, } \\
\text { dis- } \\
\text { solved } \\
(\mu \mathrm{g} / \mathrm{L})\end{array}$ & $\begin{array}{c}\text { Alum- } \\
\text { inum, } \\
\text { dis- } \\
\text { solved } \\
(\mu \mathrm{g} / \mathrm{L})\end{array}$ & $\begin{array}{l}\text { Lith- } \\
\text { ium, } \\
\text { dis- } \\
\text { solved } \\
(\mu \mathrm{g} / \mathrm{L})\end{array}$ & $\begin{array}{c}\text { Sele- } \\
\text { nium, } \\
\text { dis } \\
\text { solved } \\
(\mu \mathrm{g} / \mathrm{L})\end{array}$ & $\begin{array}{c}\text { Bro- } \\
\text { mide, } \\
\text { dis- } \\
\text { solved } \\
(\mathrm{mg} / \mathrm{L})\end{array}$ \\
\hline \multicolumn{11}{|l|}{ SEPT 1983} \\
\hline $17-17$ & $<10$ & -. & 10 & $<6$ & $<3$ & - & - & $<4$ & - & $<0.10$ \\
\hline \multicolumn{11}{|l|}{ OCT } \\
\hline \multicolumn{11}{|l|}{ NOV } \\
\hline $21-21$ & $\because$ & -. & -- & -- & - & - & -- & -- & -- & $<.10$ \\
\hline $28-29$ & -- & -- & -- & -- & -- & -- & -- & -- & -- & $<.10$ \\
\hline \multicolumn{11}{|l|}{ DEC } \\
\hline 06-07 & -- & -- & -- & $<1$ & -- & -- & $<10$ & .. & $<1$ & $<.10$ \\
\hline $15-15$ & -- & -- & - & - & -- & - & -- & -- & -- & $<.10$ \\
\hline $22-22$ & -- & -- & -- & -- & -- & -- & -- & -- & -. & $<.10$ \\
\hline $24-24$ & -- & -- & - & -- & -- & -- & -- & -- & -- & $<.10$ \\
\hline $28-28$ & -- & -- & - & -. & -- & -- & -- & -- & -- & $<.10$ \\
\hline JAN 1984 & -- & $\cdots$ & - & -- & -- & -- & -- & -- & -- & $<.10$ \\
\hline $06-06$ & -. & -- & -- & -- & -- & -- & -- & -- & -- & -- \\
\hline $10-11$ & -- & -- & -- & -- & -- & -- & -- & -- & -- & $<.10$ \\
\hline $18-19$ & -- & -- & -- & -- & -- & -- & -- & -- & -- & $<.10$ \\
\hline $24-25$ & -- & -- & -. & -- & -. & - & -- & -- & -- & $<.10$ \\
\hline \multicolumn{11}{|l|}{ FEB } \\
\hline $15-17$ & -- & -- & -- & -- & -- & -- & -- & -- & -- & $<10$ \\
\hline $24-24$ & -- & -- & -- & -- & -- & -- & -- & -- & -- & $<.10$ \\
\hline
\end{tabular}


Table 22. Physicai data and chemical-constituent concentrations for storm -recipitation samples collected at Truro. Massachusetts, September 1983 through April 1985--Continued

\begin{tabular}{|c|c|c|c|c|c|c|c|c|c|c|}
\hline Date & $\begin{array}{c}\text { Molyb- } \\
\text { denum, } \\
\text { dissolved } \\
(\mu \mathrm{g} / \mathrm{L})\end{array}$ & $\begin{array}{c}\text { Nickel, } \\
\text { dis- } \\
\text { solved } \\
(\mu \mathrm{g} / \mathrm{L})\end{array}$ & $\begin{array}{l}\text { Stron- } \\
\text { tium, } \\
\text { dis- } \\
\text { solved } \\
(\mu \mathrm{g} / L)\end{array}$ & $\begin{array}{c}\text { Vana- } \\
\text { dium, } \\
\text { dis- } \\
\text { solved } \\
(\mu \mathrm{g} / \mathrm{L})\end{array}$ & $\begin{array}{c}\text { Zinc, } \\
\text { dis- } \\
\text { solved } \\
(\mu \mathrm{g} / \mathrm{L})\end{array}$ & $\begin{array}{l}\text { Anti- } \\
\text { mony, } \\
\text { dis- } \\
\text { solved } \\
(\mu \mathrm{g} / \mathrm{L})\end{array}$ & $\begin{array}{l}\text { Alum; } \\
\text { inum, } \\
\text { dis- } \\
\text { solved } \\
(\mu \mathrm{g} / \mathrm{L})\end{array}$ & $\begin{array}{l}\text { Lith- } \\
\text { ium, } \\
\text { dis- } \\
\text { solved } \\
(\mu \mathrm{g} / \mathrm{L})\end{array}$ & $\begin{array}{c}\text { Sele- } \\
\text { nium, } \\
\text { dis } \\
\text { solved } \\
(\mu \mathrm{g} / \mathrm{L})\end{array}$ & $\begin{array}{c}\text { Bro- } \\
\text { mide, } \\
\text { dis- } \\
\text { solved } \\
(\mathrm{mg} / \mathrm{L})\end{array}$ \\
\hline \multicolumn{11}{|c|}{ FEB 1984--Continued } \\
\hline $28-29$ & -- & .- & - & -- & -- & -. & -- & -- & -- & $-<0.10$ \\
\hline \multicolumn{11}{|l|}{ MAR } \\
\hline $13-14$ & -- & - & -- & -- & -- & .- & -- & -- & -- & $<.10$ \\
\hline $17-20$ & -- & - & -- & 1 & -- & -- & $<10$ & -- & $<1$ & $<.10$ \\
\hline $21-22$ & -- & .. & -- & -- & -- & -_ & -- & -- & -- & $<.10$ \\
\hline $29-31$ & - & -- & -- & 1 & -- & .- & 20 & -- & $<1$ & .18 \\
\hline \multicolumn{11}{|l|}{ APR } \\
\hline $05-05$ & -- & .- & -- & $<1$ & -- & -. & 20 & -- & $<1$ & $<.10$ \\
\hline $15-16$ & - & -- & -- & $<1$ & -- & -- & $<10$ & -- & $<1$ & $<.10$ \\
\hline $19-19$ & - & -- & -- & -- & -- & -- & -- & -- & -- & $<.10$ \\
\hline $23-25$ & -n & -- & -- & 1 & -- & -- & $<10$ & -- & $<1$ & $\ldots$ \\
\hline \multicolumn{11}{|l|}{ MAY } \\
\hline 03-04 & -- & -- & -- & 1 & -- & $\ldots$ & -- & -- & -- & -- \\
\hline 08-09 & $\cdots$ & -- & -- & -- & -- & -- & -- & -- & -- & -- \\
\hline $20-21$ & - & .. & -- & -- & -- & .- & -- & -- & -- & -- \\
\hline $23-24$ & - & -- & -- & -- & -- & -- & - & -- & -- & -- \\
\hline $26-26$ & - & - & 10 & -- & - & -- & -- & -- & -- & - \\
\hline $28-29$ & - & -- & -- & -- & -- & -- & -- & -- & -- & -- \\
\hline \multicolumn{11}{|l|}{ MAY 31- } \\
\hline JUNE 02 & - & -- & -- & $<1$ & -- & -- & 10 & - & $<1$ & -- \\
\hline \multicolumn{11}{|l|}{ JUNE } \\
\hline $07-07$ & - & -- & -- & -- & -- & -- & -- & -- & -- & -- \\
\hline $18-19$ & - & -- & - & -- & -- & -- & -- & - & -- & -- \\
\hline $24-26$ & -- & -- & -- & $<1$ & -- & -. & 10 & -- & $<1$ & -- \\
\hline \multicolumn{11}{|l|}{ JULY } \\
\hline $07-08$ & -- & -- & -- & 1 & -- & .. & $<10$ & -- & $<1$ & -- \\
\hline $18-18$ & -- & -- & -- & $<1$ & -- & $\ldots$ & 30 & -- & $<1$ & -- \\
\hline $21-22$ & -- & - & -- & -- & -- & -- & -- & -- & -- & -- \\
\hline $27-27$ & -- & -- & -- & -- & -- & .- & -- & -- & -- & -- \\
\hline \multicolumn{11}{|l|}{ AUG } \\
\hline $07-07$ & -- & .- & -- & -- & -- & -- & -- & -- & -- & -. \\
\hline \multicolumn{11}{|l|}{ SEPT } \\
\hline 03-04 & -- & -- & -- & 1 & -- & - & 10 & -- & -- & .. \\
\hline $12-12$ & -- & -- & -- & -- & -- & -- & -- & -- & -- & .. \\
\hline $14-15$ & -- & -- & -- & 1 & -- & $\therefore$ & $<10$ & -- & $<1$ & $<.010$ \\
\hline \multicolumn{11}{|l|}{ OCT } \\
\hline $01-02$ & -- & . & -- & $<1$ & -- & - & 20 & -- & $<1$ & .030 \\
\hline $23-23$ & -- & -- & -- & $<1$ & -- & _- & -- & -- & -- & $<.010$ \\
\hline $24-24$ & -- & -- & -- & -- & -- & -- & -- & -- & -- & -- \\
\hline $29-29$ & -- & 1 & -- & 2 & -- & $<1$ & 10 & -- & $<1$ & $<.010$ \\
\hline \multicolumn{11}{|l|}{ NOV } \\
\hline $11-12$ & $<10$ & - & 1 & $<6$ & 6 & -- & 20 & $<4$ & - & -- \\
\hline $13-14$ & $<10$ & -- & 3 & -- & 40 & -- & - & $<4$ & -- & .060 \\
\hline $16-16$ & - & -- & -- & .- & -- & -. & -- & -- & -- & -- \\
\hline $29-29$ & $<10$ & $\ldots$ & 1 & -- & $<3$ & -- & -- & $<4$ & -- & -- \\
\hline \multicolumn{11}{|l|}{ DEC } \\
\hline 03-03 & -. & -- & -- & -- & -- & - & -- & .- & -- & -- \\
\hline 06-06 & $<10$ & - & 5 & $<1$ & $6^{\circ}$ & -- & -- & $<4$ & - & .040 \\
\hline
\end{tabular}


Table 22. Physical data and chemical-constituent concentrations for storm-precipitation samples collected at Truro, Massachusetts, September 1983 through April 1985--Continued

\begin{tabular}{|c|c|c|c|c|c|c|c|c|c|c|}
\hline Date & $\begin{array}{c}\text { Molyb- } \\
\text { denum, } \\
\text { dissolved } \\
(\mu \mathrm{g} / \mathrm{L})\end{array}$ & $\begin{array}{c}\text { Nickel, } \\
\text { dis- } \\
\text { solved } \\
(\mu \mathrm{g} / \mathrm{L})\end{array}$ & $\begin{array}{l}\text { Stron- } \\
\text { tium, } \\
\text { dis- } \\
\text { solved } \\
(\mu \mathrm{g} / \mathrm{L})\end{array}$ & $\begin{array}{c}\text { Vana- } \\
\text { dium, } \\
\text { dis- } \\
\text { solved } \\
(\mu \mathrm{g} / \mathrm{L})\end{array}$ & $\begin{array}{c}\text { Zinc, } \\
\text { dis- } \\
\text { solved } \\
(\mu \mathrm{g} / \mathrm{L})\end{array}$ & $\begin{array}{c}\text { Anti- } \\
\text { mony, } \\
\text { dis- } \\
\text { solved } \\
(\mu \mathrm{g} / \mathrm{L})\end{array}$ & $\begin{array}{c}\text { Alum- } \\
\text { inum, } \\
\text { dis- } \\
\text { solved } \\
(\mu \mathrm{g} / \mathrm{L})\end{array}$ & $\begin{array}{l}\text { Lith- } \\
\text { ium, } \\
\text { dis- } \\
\text { solved } \\
(\mu \mathrm{g} / \mathrm{L})\end{array}$ & $\begin{array}{c}\text { Sele- } \\
\text { nium, } \\
\text { dis } \\
\text { solved } \\
(\mu \mathrm{g} / \mathrm{L})\end{array}$ & $\begin{array}{c}\text { Bro- } \\
\text { mide, } \\
\text { dis- } \\
\text { solved } \\
(\mathrm{mg} / \mathrm{L})\end{array}$ \\
\hline \multicolumn{11}{|c|}{ DEC 1984-Continued } \\
\hline $10-10$ & -- & -- & -- & -- & -- & -- & -- & -- & -- & .. \\
\hline $15-15$ & -- & -- & -- & -- & -- & -- & -- & - & -- & - \\
\hline $19-19$ & $<10$ & -- & 1 & 1 & 17 & - & -- & $<4$ & -- & $<0.010$ \\
\hline $21-22$ & $<10$ & - & 3 & $<1$ & 12 & -- & $<10$ & $<4$ & -- & .020 \\
\hline $24-25$ & -- & -- & -- & -- & -- & .- & -- & -. & -- & - \\
\hline $28-28$ & -- & -- & -- & $<1$ & -- & -- & -- & -- & -- & $<.010$ \\
\hline \multicolumn{11}{|l|}{ JAN 1985} \\
\hline $02-02$ & -- & -- & - & 1 & -- & -- & -- & -- & -- & .020 \\
\hline $07-08$ & -- & -- & -- &.- & -- & - & 10 & - & -- & - \\
\hline $17-18$ & -- & -- & - & -- & -- & -- & -- & -- & -- & - \\
\hline \multicolumn{11}{|l|}{ JAN 31- } \\
\hline FEB 03 & $<10$ & $<1$ & 2 & 1 & 15 & -- & -- & $<4$ & - & .010 \\
\hline \multicolumn{11}{|l|}{ FEB } \\
\hline $05-07$ & $<10$ & -- & 1 & $<6$ & 27 & -- & -- & $<4$ & -- & .030 \\
\hline $12-13$ & $<10$ & -- & 5 & $<6$ & 21 & $<1$ & -- & $<4$ & -- & .12 \\
\hline $23-23$ & - & - & -- & -- & -- & -- & -- & -- & -- & - \\
\hline \multicolumn{11}{|l|}{ MAR } \\
\hline $02-02$ & -. & -- & -- & -- & -- & -- & -- & -. & -- & - \\
\hline $04-05$ & $<10$ & -- & 4 & 1 & 12 & -- & -. & $<4$ & -- & $<.010$ \\
\hline $08-08$ & -- & -- & - & -- & -- & -- & -- & -. & -- & - \\
\hline $12-12$ & $<10$ & $<1$ & 1 & 1 & 4 & $<1$ & 10 & 6 & $<1$ & $<.010$ \\
\hline $17-18$ & - & -- & -- & -- & -- & -- & -- & -- & -- & - \\
\hline MAR 31- & & & & & & & & & . & \\
\hline APR 01 & - & -- & - & -- & -- & -- & -- & -- & - & - \\
\hline \multicolumn{11}{|l|}{ APR } \\
\hline $08-08$ & - & -- & $\cdots$ & -- & -- & -- & - & -- & -- & - \\
\hline
\end{tabular}

